Claremont Colleges

Scholarship@ Claremont

CGU Theses \& Dissertations

CGU Student Scholarship

2012

\title{
Covenant Nation: The Politics of Grace in Early American Literature
}

Justin M. Scott-Coe

Claremont Graduate University

\section{Recommended Citation}

Scott-Coe, Justin M.. (2012). Covenant Nation: The Politics of Grace in Early American Literature. CGU Theses \& Dissertations, 45. http://scholarship.claremont.edu/cgu_etd/45. doi: 10.5642/cguetd/45

This Open Access Dissertation is brought to you for free and open access by the CGU Student Scholarship at Scholarship @ Claremont. It has been accepted for inclusion in CGU Theses \& Dissertations by an authorized administrator of Scholarship @ Claremont. For more information, please contact scholarship@cuc.claremont.edu. 


\title{
COVENANT NATION:
}

\section{THE POLITICS OF GRACE IN EARLY AMERICAN LITERATURE}

\author{
by \\ Justin M. Scott-Coe
}

Claremont Graduate University

2012

(C) Copyright Justin M. Scott-Coe, 2012

All rights reserved. 


\title{
APPROVAL OF THE REVIEW COMMITTEE
}

This dissertation has been duly read, reviewed, and critiqued by the Committee listed

below, which hereby approves the manuscript of Justin Scott-Coe as fulfilling the scope and quality requirements for meriting the degree of $\mathrm{Ph} . \mathrm{D}$. in English.

\author{
Dr. Wendy Martin, Chair \\ Claremont Graduate University \\ Professor of American Literature and American Studies
}

Dr. Robert Hudspeth

Claremont Graduate University

Research Professor of English

Dr. Henry Krips

Claremont Graduate University

Professor of Cultural Studies 


\begin{abstract}
Covenant Nation: The Politics of Grace in Early American Literature

by

Justin M. Scott-Coe

Claremont Graduate University: 2012
\end{abstract}

The argument of this dissertation is that a critical reading of the concept of "covenant" in early American writings is instrumental to understanding the paradoxes in the American political concepts of freedom and equality. Following Slavoj Žižek's theoretical approach to theology, I trace the covenant concept in early American literature from the theological expressions and disputes in Puritan Massachusetts through Jonathan Edwards's Freedom of Will and the essays of Ralph Waldo Emerson, showing how the covenant theology of colonial New England dispersed into more "secular" forms of what may be called an American political theology. The first chapter provides an overview of recent attempts to integrate theology and theory, specifically comparing Jacques Derrida and Žižek to better understand the latter's theology of materialism which relies on as well as informs the Reformed Protestant covenantal dichotomy of grace and works. The second chapter establishes the complicated architecture of the covenant concept within seventeenth-century New England Reformed Protestantism, and uses church membership transcripts along with Ann Hutchinson court trial documents to demonstrate how this inherently unstable theology created unintended slippage between God's grace and mankind's works, resulting in a theological formulation remarkably open to Žižek's analysis of political ideology. 
The third chapter demonstrates how Jonathan Edwards, through his ingenious counter-argument in Freedom of Will, provides a theoretical foundation for an uneasy but necessary alignment of the covenants of works and grace, releasing the subjunctive potential of grace to operate through history as a predeterminer of meaning and, potentially, freedom. In the last chapter, I argue that Emerson finally converts the covenant from a politically conceptualized theological framework for radical grace into a personal institutionalization of grace itself. Stanley Cavell's exploration of Emerson's "constitution" in light of the covenant motif demonstrates the political (im)possibilities inherent in America's self-conceptions of personal liberty and civic equality. In the end, complexities inherent in the concept of the covenant, especially its creative failure to control the radical nature of "grace," are determinative factors in our contradictory American egalitarian ideals. 
For Jo,

a new beginning 


\section{ACKNOWLEDGMENTS}

I would like to recognize a few of the many people who have been so generous with their time, encouragement, and emotional and financial support over the past thirteen years. First, I thank the current and former members of my dissertation committee, especially Wendy Martin for her resourcefulness and patience in chairing the committee. Marc Redfield, upon moving to Brown University, graciously facilitated an introduction to Henry Krips, who agreed to replace him on my committee and has provided significant assistance in my reading of Žižek. My deepest gratitude goes to Robert Hudspeth for his never-ending encouragement, his incredibly helpful comments on draft chapters, his books, and his belief in my "daunting" project. I want to thank Claremont Graduate University for its 2011 "Late Finishers" workshop, led by Janet Brodie, which helped me push this project over the finish line. I also received specific advice, comments, and encouragement from Suzanne Arakawa, Glenn Coe, Deborah Lefkowitz, Mary Powell, Jo Scott-Coe, and Norman Wendth. This dissertation could not have been completed without the support of my employer, Monte Vista Water District. General Manager Mark Kinsey and Public Affairs Director Mary Ann Melleby provided me with the time and the flexibility required to accomplish this work. My family, both immediate and extended, has constantly cheered me on; they no doubt breathe a sigh of relief that they will no longer face my pained expression when asking how the doctorate's coming along. I thank my mother and father, Glenn and Judy Coe, for being so proud of their son, even when he's not comprehensible. I thank my aunt, Jeanine McNeill, for providing such a beautiful location to struggle with this material. Finally, I thank Jo for being my strength, my love, and my life. This is for you. 


\section{TABLE OF CONTENTS}

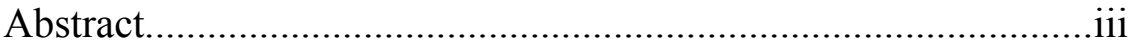

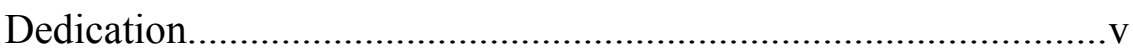

Acknowledgments..................................................................... vi

Table of Contents........................................................................ vii

Introduction...................................................................................1

Covenant in the Reformed Protestant Context.....................5

Equality and the Covenant.............................................12

Early American Religion in the Academy.........................15

Notes on Methodology...............................................21

Overview..................................................................26

Chapter 1: The Unconscious Covenant.....................................28

Theology and the Political..............................................34

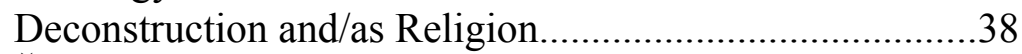

Žižek's Materialist Theology.......................................48

Chapter 2: The Covenant is Reformed.....................................64

History of the Reformed Covenant - Grace and Works.....68

Practice of the Reformed Covenant - Grace at Work........91

Chapter 3: Converting the Covenant........................................122

Will in the World - Reading Edwards............................124

Will and Grace - Edwards and the Covenant...................131

Grace Means Work - Reading Freedom of Will...............142

Chapter 4: Emerson's Constitution.........................................160

Unconscious Theology - Reading Emerson.....................163

Emerson's Monsters - Theorizing Emerson.....................171

The Nature of Grace - Nature and Addresses..................181

Third World of the Spirit - "Self-Reliance,"

"Experience," "Fate"

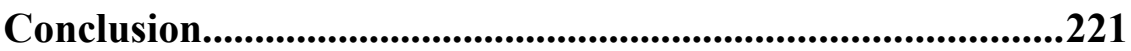

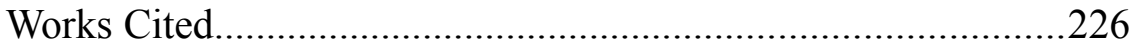




\section{INTRODUCTION}

Those who say religion has nothing to do with politics

do not know what religion is.

Mohandas K. Gandhi

No one expects equality. Equality is not a good thing, and you can't

have an economy that works if everything is equal. But too much

inequality also has negative consequences.

Rep. Barney Frank, U.S. House of Representatives, 2008

Religion has received a renewed emphasis in public discourse following the attacks of September 11, 2001, and, after the initial cacophonous reaction, one can now identify discernible threads in the popular literature of a widening debate over the status of religion in modern society. On one side of the spectrum, a new "fundamentalist atheism" movement congealed in 2006-07 around published manifestos by leading public intellectuals Christopher Hitchens, Sam Harris, Daniel Dennett, and Richard Dawkins against revealed religion and its involvement in modern politics. ${ }^{1}$ On the other side, writers as diverse as Ann Coulter, Chris Hedges, and Jim Wallis from both the right and left political wings argue for the necessity of religion's central place in American politics and culture in the face of misguided values, secular religiosity, and

1 Hitchens, God is Not Great: How Religion Poisons Everything (2007); Harris, The End of Faith: Religion, Terror, and the Future of Reason (2004) and Letter to a Christian Nation (2006); Dennett, Breaking the Spell: Religion as a Natural Phenomenon (2006); and Dawkins, The God Delusion (2006). For an overview of the "fundamentalist atheism" movement, see Gottlieb. For rejoinders to the movement in the popular press, see Dinesh D'Souza, What's So Great About Christianity (2007); and Chris Hedges, I Don't Believe in Atheists (2008). 
simple "evil."2 In the middle stands a high-pitched public discourse on the proper place of religion in American political life. In 2007, John Grey pronounces in Black Mass: Apocalyptic Religion and the Death of Utopia that "Modern politics is a chapter in the history of religion" (1), while Mark Lilla in The Stillborn God: Religion, Politics, and the Modern West bemoans, "Today we have progressed to the point where we are again fighting the battles of the sixteenth century" (3). One year later, popular comedic commentator Sarah Vowell, in The Wordy Shipmates, put on her buckled shoes and trod the well-worn path back to seventeenth-century New England to explain America's inbred religiosity. There, she finds the source of the contradictory communal benefits and exceptionalist detractions inherent in American political culture and ideals, all leading toward the world's violent response; in John Cotton's farewell sermon to the Winthrop fleet, Vowell says, is "the match still lighting the fuses of a thousand car bombs" (2).

Many commentators view the events of $9 / 11$ as a brutal refutation of cultural theorist Francis Fukuyama's thesis in The End of History and the Last Man (1992) that economic globalization promised to end history's ideological conflicts. It is telling, then, that Fukuyama chose to reenter the debate in 2005 wielding a cultural theory which similarly melds ideology and economics. His essay, "The Calvinist Manifesto," published in The New York Times Book Reviews section, commemorates the one hundredth anniversary of the publication of Max Weber's The Protestant Ethic and the Spirit of Capitalism (1904-05), and argues that the work ethic espoused by Weber's Protestants "deserve[s] a fresh look" in the new post-9/11 context. Weber's work famously puts forward a controversial and overly simplified thesis of the Reformed Protestants' (more commonly known as Calvinists) drive to demonstrate predestined

2 See Coulter, Godless: The Church of Liberalism (2007); Wallis, God's Politics: Why the Right Gets It Wrong and the Left Doesn't Get It (2005); and Hedges, Losing Moses on the Freeway: The 10 Commandments in America (2006). 
elect status through a diligent work ethic was a direct progenitor of Western and particularly American-style capitalism. Ironically, Weber relies on a psychologized version of Reformed Protestant theology rather than an in-depth look at their consistent deployment of "Old Testament" concepts—in particular, a covenantal relationship with God and national electionconcepts which Weber later was instrumental in explicating through his own biblical scholarship. ${ }^{3}$

Thanks in no small part to Weber's early simplifications, carried forward by such widely read commentators as Fukuyama and Vowell, the seventeenth-century Reformed Protestant "Puritan" settlers of New England are consistently used as a sort of ping pong ball in the American political "culture wars," praised or (more often) blamed for America's supposed acquisitiveness and economic acumen. Fukuyama's preference for Weber's "Calvinists" is meant to counter a popularized negative view of our Puritan forebears. Vowell, in a more complicated gesture, attempts to play both sides of the table in explaining our current post-secular circumstances, skillfully employing a mixture of humor and history, as well as ample romanticization and overdetermination. Unfortunately, despite pretenses to the contrary, her jaunty, overly familiar approach makes it all too easy to dismiss the Puritans to the realm of black hats and burned witches. ${ }^{4}$ In short, the continued interest in the Puritans as a fundamental element of our cultural heritage, and as instigator of our political, economic, and religious positioning on the world stage, belies the continued lack of seriousness we give to Puritan ideas.

3 For a comprehensive critique of Weber's Protestant Ethic thesis, see Samuelsson. For a specific critique of Weber's conceptual construction of "ascetic" Reformed Protestantism, see Ghosh. For a short history of Weber's Ancient Judaism (1921) and its influence on future biblio-historical studies of the Judaic covenant tradition, see Nicholson (38-44).

4 The cover of Vowell's book, which has a photo of little toy Puritan figurines arranged on a beach, provides an appropriate image of the continued infantilization and famil(iar)ization of the Puritans. Her Puritans are cast as those harmless fundamentalist relatives you're forced to spend Christmas with. 
An excellent example of this dual fascination and blindness to the role of Puritan concepts in American politics is a recent comprehensive analysis of President Bill Clinton's rhetorical consistency in regard to his own political philosophy. In "A 'New Covenant' Kept: Core Values, Presidential Communications, and the Paradox of the Clinton Presidency," Robert Durant argues against those who find Clinton's presidency had no consistent policy, and shows instead that Clinton's deployment of the "New Covenant" themes of "community, opportunity, and responsibility" were consistent and ever-present in both his political rhetoric and governmental initiatives. However, Durant also finds that Clinton failed to "brand" and indeed rarely used the term "New Covenant" itself in defining his policy (as opposed to, say, Reagan's "New Day in America" theme), resulting in a "rhetorical paradox" for his presidency (347). ${ }^{5}$ What is striking is that Clinton's "New Covenant" philosophy, as defined by Durant—-a core set of beliefs about the appropriate relationship between citizens and the state" (345) presupposing "a sense of mutual obligation between citizens and the state" (369) — is entirely consistent with the Reformed Protestant use of the covenant concept, which, as I hope to show, is itself inherently paradoxical. Furthermore, Durant suggests that Clinton's "third way" ideal of government helping people help themselves goes beyond simple paradox and approaches the transcendental: "the New Covenant was beyond, not between, the ideologies of the left and the right" (352). Durant successfully identifies Clinton's consistent use of his "New Covenant" philosophy to direct government policy throughout the 1990s, but remains mystified by Clinton's

5 In reference to "New Covenant," "Of [Clinton's] 4,328 communications, the branding phrase 'New Covenant' appears only 101 times" (365). More specifically, the three terms "community," "opportunity," and "responsibility" were used repeatedly in both his inaugural addresses, but not "New Covenant." However, "New Covenant" is used repeatedly as the organizing theme of a series of lectures in 1991 used to define his candidacy for president, and again is used twelve times in his 1995 State of the Union address following significant electoral losses in 1994, showing that its use may have been more strategic than representative (351, 359-60, 366). 
strange inability to solidify a reputation for having done so. I would argue that the paradoxes inherent in the covenant concept, as developed through the Reformed Protestant tradition, help to explain this apparent contradiction.

It is my argument that a critical reading of the concept of "covenant" in early American writings is instrumental to understanding similar paradoxes in American political concepts, in particular that of equality. I will attempt to trace the origin and pathway of the covenant concept in early and nineteenth-century American literature from the theological expressions and disputes of the Puritan Massachusetts colonists through the essays of Ralph Waldo Emerson. I hope to show how the covenant, as a key religious concept for the New England Puritans, dispersed into more "secular" forms of what may be called an American political theology. The complexities inherent in the concept of the covenant, specifically in its creative failure to control the radical nature of "grace," will be shown to be a determinative factor in the contradictory American egalitarian ideal.

\section{Covenant in the Reformed Protestant Context}

"Covenant," from its first use in early Medieval England, has been an unstable term or category, incorporating divergent, at times contradictory elements. A form of the word in English has been in use since at least the twelfth century, and appears to have first meant a coming together, an agreement (entering English from the Old French "covenable", to agree). Though its original meaning suggests a mutual agreement, compact, contract, or bargain between two or more parties to do (or not do) something, the term has become more specialized both legally and theologically. Under the former, the term has been used in English Common Law since the 
Norman Conquest as the vernacular equivalent to the Latin conventio, or a formal agreement, promise, or contract made "under seal;" also, the clauses of such an agreement ("covenant", $O E D)$.

The progressive English-language translations of the Bible from the fourteenth to seventeenth centuries clearly draw on the interpretative power of such solemn legal agreements

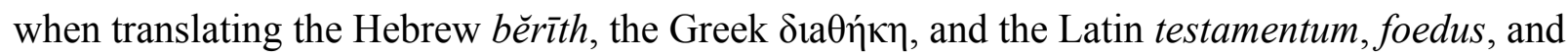
pactum as "bond," "testament," and, with increasing regularity in later versions, "covenant." These associations coincide with the rise in influence of Reformed theology among Englishspeaking Protestants. The migration of the "covenant" from Wyclif's limited use primarily in the Hebrew Bible or "Old Testament" portion of his Bible to its widespread use in the Geneva and King James Bibles' New Testaments parallels the progressively stark contrast in Reformed theology between the "Old Covenant" based on Old Testament "works" and the "New Covenant" based on New Testament "grace." Thus, "covenant theology," though originally developed in Switzerland and the Netherlands, had a direct bearing in the English context on the very terms on which the theology is based.

One controversial aspect of the covenant concept as it relates to biblical texts is its possible origins in ancient Sumerian and Akkadian treaties going back as far as 2,500 B.C.E. These treaties were most often between drastically unequal parties, usually a conquering ruler and a vassal state, making them not the best model for "mutual assistance" from the vantage point of a more modern sensibility, but an excellent analogue for the relationship between God and humankind. To avoid any confusion, these treaties were structured with standard "clauses" providing signatories with a history of their relationship (who conquered whom), binding oaths, 
and curses for breaking the oath - a structure some scholars see replicated in several places in the Hebrew Bible. ${ }^{6}$ Ernest Nicholson, however, in one of the central studies of the biblical covenant, God and His People: Covenant and Theology in the Old Testament (1986), rejects this political origin of the biblical covenant as an imposition of late biblical authors, and instead points to free choice within the Judaic faith as a distinctive element of the covenant:

The concept of a covenant between Yahweh and Israel is ... the concept that religion is based, not on a natural or ontological equivalence between the divine realm and the human, but on choice: God's choice of his people and their 'choice' of him, that is, their free decision to be obedient and faithful to him. (215-6)

The indeterminacy of whether or not this "choice" is in fact a "free decision," implying an equity (if not equivalence) between God and humankind at the level of freedom to choose one's fealty, is elemental to understanding the instability of the covenant concept.

It is ironic, therefore, that covenant theology developed within Reformed Protestantism as a mode of stabilizing the radical nature of God's grace. Current interdenominational battles, such as the one within Presbyterianism between the covenant theologians and dispensationalists, can be traced back to the formation of the Reformed branch of Protestant thought in the stormy sixteenth century, culminating at the Synod of Dort in 1619, when the Reformed Calvinists defined themselves against the followers of Arminius based on five precepts:

1) Total depravity of humanity,

2) Unconditional election,

3) Limited atonement for the Elect through Christ's crucifixion,

4) Irresistible grace, and

${ }_{6}$ For a popularized version of this theory, see Delbert R. Hillers, Covenant: The History of a Biblical Idea (1969). 
5) Perseverance of the saints toward salvation.

These precepts of classical Calvinism, colloquially known by the acronym "TULIP," were (and are) generally accepted across the mainstream Reformed Protestant world, but left not much to earthly control over one's destiny, necessitating an understandable (and, one hopes, predictable) governing structure for divine decision-making. The Reformed Protestant tradition, including the New England Puritans escaping the Arminian takeover of the Church of England, extracted such a structure from the biblical idea of the covenant, and developed the covenant concept of a providential yet contractual relationship between God and humanity into a complicated political architecture that incorporated relationships within the Godhead as well as the formation of churches.

The Puritans who emigrated to New England brought with them a fully developed Reformed Protestant covenantal theology that, despite much debate among religious historians, was basically the same as that of other Reformed Protestants in the Netherlands, Germany, France, Switzerland, Poland, and Transylvania. What distinguishes the English from their European peers was the way the New England Puritans were able to set up a social, governmental, and ecclesiastical system based on their covenantal ideals without overweening social and political pressures to modify their principles from a preexisting landed elite or predominant (or state-imposed) confession of faith. Without over-romanticizing their projectand it has been done plenty - the New England Puritans were, from the very beginning, able to attempt an experiment in creating a theocracy, a government based on distinct theological principles, with only the immediate harshness of their physical environment (including, for them, encounters with the Native American populations) as an obstacle. ${ }^{7}$

7 The Puritans were, of course, under constant threat from the various changing governments in England, but this 
It is telling, therefore, that their greatest impediment to their theocratic project from nearly the moment of landing in Massachusetts can be found in the very theology they brought with them. The instability of their "covenant of grace" doctrine, as I will show, produced almost spontaneous doctrinal aberrations from what became known as the "New England Way." The concept of the covenant was employed selectively and strategically to counter threats to their system of theocratic governance, and became a flexible ideological framework for regulating both the God-to-human theological relationship based on "free grace" as well as human-tohuman political relationship based on one's (hoped for) membership in the "invisible church" of God's predestined Elect.

Thus, the term "covenant" came to be directly associated with Puritan New England's truly exceptional social experiment, and was used in describing this experiment, which they were aware of and described as being unique in Western Christendom. As the experiment developed, devolved, and dispersed into a pluralistic colonial society of denominational churches, increasingly diverse immigrants, and shifting centers of political power, the covenant concept and its associated senses of divine and human relationship modified as well. Some scholars (and a number of college textbooks ${ }^{8}$ ) go so far as to directly associate the Puritan covenant with American constitutional thought, as a political contract with a spiritual dimension that may have

threat focused mostly on their political independence, not on the theological basis of their government, and only touched on their theological convictions through an increased pressure for tolerance of other religions.

8 For textbooks on politics and religion that point to a direct connection between covenant and constitutional thought, see Corbett and Hemeyer (33-38), Wald (46-49 passim), Dunn (14, 172 passim), and Moseley (5-14). Wald, in his standard textbook Religion and Politics in the United States (2003), asserts the strongest link, which leads to an erroneousness association between the New England Puritan covenant and Lockean (or even Rousseauian) political theory: "As the Puritans understood it, the defining characteristic of a covenant was that of a voluntary agreement, sanctified by God, in which individuals freely surrendered autonomy in exchange for something of greater value" (96). Regardless of the indeterminacy surrounding "choice" in the covenantal relationship (a topic to be discussed at length in this work), no predestinarian New England Puritan could have conceived of their covenantal relationship with God as "voluntary" or their faith in election as "freely surrender[ing] autonomy in exchange for something of greater value." 
had some influence on the development of and veneration for America's national constitutional polity, inadvertently preparing the populace for the Lockean "social contract" underpinning the U.S. Constitution. According to John Smith, Benjamin Franklin "knew how to use the doctrine underlying the Puritan covenant theology to establish the idea of a secular commonwealth" (qtd. in Shea and Huff 196). Daniel Elazar, in his three-volume study Covenant Tradition in Politics (1995, 1996, 1998), makes the most expansive argument of a direct linkage between the biblical covenant tradition, Reformed Protestant theology, and American constitutional federalism. ${ }^{9}$

One can readily see that the covenant concept threatens to become one of those easy analogues between American religiosity and democratic political practice, like the election of ministers and elected representatives, the sermon and the campaign speech, or camp meetings and campaign rallies. In reality, however, covenant is not so much a metaphorical political analogue as it is an historical theologico-political part of the Puritans' practical theology. As so many post-Perry Miller scholars of New England theology have assessed, the concept of covenant along with other Puritan theological concepts were flexible, messy, and contingent on the necessity of the political situation — and even the argument of the given sermon or the assessment of personal sanctification for a particularly influential church member. This slipperiness made the concept quite useful up until the term itself became too weighted and outmoded for wide-spread use under the differing eighteenth-century religious practices. Even so, I will argue that the idea the term came to represent-a compact between unequal parties that nevertheless gives a semblance and even a promise of equality—continued to be useful in structuring and rhetorically enforcing authority over a society of "free" individuals.

\footnotetext{
Michael Hughey is another major proponent within the intellectual history community; see his essay "The Political Covenant: Protestant Foundations of the American State."
} 
The use of the word "covenant" today is for the most part emphatic, strategic, and vague, most often signifying a calling with both political and spiritual dimensions. ${ }^{10}$ The current Obama presidential administration, though not using the term to define its political philosophy, consistently cites "responsibility" and other stand-ins similar to the Clinton administration. ${ }^{11}$ Probably the most well-known and emphatic current use of the covenant concept is Tavis Smiley's The Covenant with Black America (2006), a political action plan initiated in the preObama era to address major concerns in the African American community. Interestingly, the covenant form is neither defined nor historicized in Smiley's Covenant, suggesting it is understood by its primarily African American audience which has been well supplied with biblical motifs by the Black Church — and all too familiar with the lived experience of inequality. Smiley's Covenant, however, clearly matches the New England covenantal form of community formation under a higher power, authority and/or mission, a "calling out" to political action through the formation of what Winthrop would call a "rightly ordered" or, to use Smiley's terms, "organized and mobilized" community. ${ }^{12}$

10 A "covenant" still signifies a formal clause in legal documents. An exemplary vague use of the term that involves neither politics nor religion can be found in a recent New York Times op-ed in which David Brooks seeks to establish one's "higher" commitment to educational institutions as "more like a covenant" than one's connection to an occupation, sport, or piece of property.

11 The term has been used by others to describe the Obama administration, but from outside both the Protestant and U.S. contexts. British Rabbi Jonathan Sacks described Obama's election in The Times (London) as "renewing the covenant," and explained to his English audience that "in the US it is more than a word: it is its defining purpose as 'one nation under God'. In a sense deeper than we can readily imagine, America sees itself as a covenanted nation." However, in a general search of the U.S. press, I cannot find one instance of the term being used to describe Obama's candidacy or presidency (LexisNexis search, "Obama AND covenant," February 1, 2009).

12 The closest The Covenant comes to formal self-reference is at the end of Cornell West's benedictory "Call to Action" when he states:

Our Covenant is neither a contract nor a compact. A contract is too selfish and a compact is too seasonal. Now is the time for us to keep faith with our spiritual, moral, and political covenant bequeathed to us by great foremothers and forefathers that simply says: "Stand with grace and dignity and take action with courage and compassion, with malice toward none yet a righteous indignation against injustice, so that everyday people — and especially their precious children — can flower and flourish as the sun shines and the stars shout for joy. (240)

The final quotation, laced with famous phrases from speeches and song, is an inferred covenant rising from a tradition not explicitly discussed but most certainly expressed, less formally than evocatively conceived in its 


\section{Equality and Covenant}

In addition to "covenant," the term "equality" needs to be explored before moving

forward. Equality is a difficult concept to particularize, due to both its indeterminacy (equal to whom? on what basis?) as well as its political freight. Most often, political equality is discussed within the framework of particular groups historically (and continually) excluded from political agency: women, ethnic and racial minorities, the global poor, non-hetero-sexualities, the disabled, and other marginalized groups. ${ }^{13}$ The concept is central to the work of major political theorists from John Locke to John Rawls, and the term is flexible enough to be used by a proponent of almost any modern political persuasion. ${ }^{14}$

However, the concept of equality, in the context of both political and critical theory, is as problematic as the concept of covenant. The political equality baldly asserted in the Declaration of Independence, that "all men are created equal," is what Robert Hoffert calls a "substantive equality," which can be distinguished from the merely circumstantial equality of opportunity or condition (58) ${ }^{15}$ Amanda Emerson pushes the use of equality in the Declaration a bit farther in finding that, though its reflection of a "universal" and "inborn moral capacity" may have

most current expression. The meaning of covenant, though never positively defined, encompasses both spiritual and political efficacy, investing the "document" with the energy of a movement. Thus, covenant in general must be considered, both currently and historically, less a static literary form than an evocative vector of particular religious and political force.

13 Recent examples include, respectively, the U.N. Millennium Development Goal \#3: "Promote Gender Equality and Empower Women" (Buvinić 2008); Hayman and Ware, Choosing Equality: Essays and Narratives on the Desegregation Experience (2009); Shachar, The Birthright Lottery: Citizenship and Global Inequality (2009); Merin, Equality for Same-Sex Couples (2002); and Osgood, The History of Special Education: A Struggle for Equality in American Public Schools (2008). For a recent example of cross-currents between gender and religious equality, see Tanenbaum, Taking Back God: American Women Rising up for Religious Equality (2009).

14 For an overview of political equality as a generally desirable concept in American politics, and its future prospects, see Dahl, On Political Equality (2006). In the interest of full disclosure, my own political philosophical perspective is most in line with "libertarian socialism," best represented by Noam Chomsky's writings, which makes freedom from want a necessary antecedent to true political equality. For a good summary of Chomsky's political philosophy, see Chomsky and Otero, Radical Priorities (2003).

15 Hoffert goes on to assert that the Declaration's simple assertion of substantive equality, matched with the Articles of Confederation's establishment of a government based on agreement between communities of friendship, can together be considered a "national" and "constitutional covenant." 
originally been conceived as limited to the equivalency of colonial American and British subjects, "All agree that, in reception, equality in the Declaration comes to mean much more" (100n2, her emphasis). Emerson goes on to trace the shift in the meaning of equality during the early national debates from the "equivalency" of white citizens reflected in early republican writing in the confederation period toward an "equity"-based "admittedly uneven though impartial distribution of social standing" by the 1790s constitutional period. In the late eighteenth century, equality was both a theoretical and, in light of the French Revolution, an historical problem, and in response early American texts achieve the creation of a "myth of equality" that allows for a "surprising flexibility of meaning." This flexibility also produces what Emerson calls "negative affiliation," creation of general identity out of "dissensus" and institutionalized conflict $(79-80)^{16}$ - mirroring not only the flexibility of the earlier colonial covenant framework but also the critical theories of equality found in recent theologico-political readings of the mystical via negativa. As Emerson summarizes the conclusions of her study, substantive equality at the foundation of American political tradition was unstable and perhaps metaphysical from the start: "Rather than pointing to conditions of real equality, American equality finds its truth status in ... myth" (83).

Discussions of equality in the religious context follow a similar path, focusing on the equity of religious denominations rather than the equivalence of humanity ("under God") resulting from religious faith. A recent example of this trend is Martha Nussbaum's Liberty of Conscience: In Defense of America's Tradition of Religious Equality (2008). Nussbaum comes to the rescue of "religious equality," by which she means voluntary religion, the ability to choose one's religious faith rather than have it imposed by the state. In her argument, Nussbaum defines

16 Emerson borrows the idea of "dissensus" from Berkovitch (see Rites of Assent). 
an "equal citizen" as one who has the right to one's opinions, including one's religious faith. Thus, she is able to baldly assert, "People love in-groups that give their members special rights. Equality, and respect for equality, are difficult for human beings to sustain ... [L]iberty of conscience is worth nothing if it is not equal liberty" (1-2). Her concern over separation of church and state is against establishment and based on the equality of religious beliefs, which she equates with the equality of citizens: "Insofar as it is a good, defensible value, the separation of church and state is, fundamentally, about equality, about the idea that no religion will be set up as the religion of our nation, an act that immediately makes outsiders unequal" (11-12, her emphasis). Nussbaum defines "equality" and "equal respect" as simultaneously being founded on a "civic equality, equality of standing in the public realm" envisioned by the Founders and enshrined in American "tradition" (19). In other words, equality is a condition of the practice of religious liberty, rather than a condition of its practitioners; our tradition is one of equal respect, not of equal material conditions.

It is not a huge step from defining religious equality as the defining attribute of citizenship to defining equal citizenship itself in religious terms - in other words, using religiosity, voluntary or otherwise, to enforce equality. We find, in this vein, the covenant concept employed to support reactionary American theocentric egalitarianism in Eldon Eisenach's The Next Religious Establishment: National Identity and Political Theology in PostProtestant America (2000). Eisenach identifies a unified American "national political theology" of underlying religious and political ideals which "presupposes a national covenant," and goes on to equate the necessity of this political theology with political equality:

It is the discourse within national political theology that permits the many and 
various groups in America to speak to each other as equals [my emphasis], to explain and justify themselves to others, and to interpret and understand themselves and others as Americans. It is by national political theology that the people of America become and remain bound to each other as Americans with mutual obligations." (56, his emphasis unless otherwise indicated)

The basis of American political equality "as Americans," according to Eisenach, is one's ability to understand the discourse of political theology — analogous to one's ability to speak English, which isn't America's official language but might as well be. Similarly, America's "national covenant" isn't America's established national religion but remains an established arbiter of American equality.

The idea of a national covenant can be seen here to tap into a concept of equality that is barely recognizable yet frighteningly consistent with the unsettled nature of America's founding myth of substantive equality. How one speaks about American religion, as we will see below, can determine one's political as well as religious, and possibly national, identity.

\section{Early American Religion in the Academy}

Religion in the United States, and particularly in the early colonial period, has been of continued interest among scholars, especially in the fields of the history, sociology, philosophy, and literature. In undertaking a critical analysis of an historical theological concept, we will need to understand the status of scholarship in a broad range of academic fields dealing with these historical and cultural texts and contexts.

Intellectual historian Perry Miller was a trailblazer in identifying and elucidating key 
theological concepts in early New England, and tracing the impact of these ideas in the formation of what he called "the American mind." Among his many arguments was the idea that "certain basic continuities persist in a culture," and one of those continuities between the Puritan covenant theologians and Emerson was an effort "to confront, face to face, the image of a blinding divinity in a physical universe" without ritualistic mediation (185). I will, of necessity, make great use of Miller, but will try to show that, contrary to his notion of continuity through unmediated experience, the covenant in fact did function (more or less) as a continuing intermediary framework for spiritual and political engagement of "the other."

Sacvan Bercovitch takes up Miller's baton in arguing for continuity, though separating himself at times forcefully from the track Miller lays. While discarding Miller's "declension" motif of the decline of the New England tradition that spawned the "jeremiads" of the second and third generation ministers, Bercovitch nevertheless traces the jeremiad tradition into the late eighteenth and early nineteenth century expansionist rhetoric as providing a "ritual leveling of all sects within the framework of American religion. By their very contradictions they were made to correspond" with the push for divine inheritance of Western lands, the "New Israel" (Jeremiad 166, his emphases). Bercovitch identifies these "superstructures of the future" as "secured by Emerson," but whose "foundation was laid in seventeenth-century Massachusetts." Bercovitch's continuities are found in aesthetic literary structures, in particular typology and an archetypal "auto-American-biography ... a total assertion of the self" which "served rhetorically to resolve the conflicts inherent in the very meaning of 'free-enterprise."' The Puritan interpretive and rhetorical modes, in the end, "survived, finally, not by chance but by merit," thus lending us a particular American literature with the themes of individual and community with which we 
remain enamored (Puritan Origins 184-6).

This unifying vision, later characterized by Henry May as the "Puritan synthesis," which charted an intellectual path from Winthrop through Edwards to Emerson and beyond, dominated history of religion departments from the 1930s through the 70s (Stout and Hart 3). Such a synthesis clearly betrays an exceptionalist viewpoint of modern American ideals and identity built upon an historical ideational infrastructure, and it has since been successfully challenged. Patricia Bonomi's Under the Cope of Heaven: Religion, Society, and Politics in Colonial America (1986) and Jon Butler's Awash in a Sea of Faith: Christianizing the American People (1990) represent the fullest expressions of this pulling away from the seventeenth century as an originary source for American religiosity, and the pull has continued to the point that, according to David Hall, "Within the community of historians of religion Puritanism has been eclipsed by the proposition that the story of a Christian America dates from the early nineteenth century and the onset of evangelicalism" (83n88). ${ }^{17}$ My account of the covenant is consistent with Butler and Bonomi's anti-declensionist assertion of increased "Christianization" and the development of a "social religion" fully integrated with politics in the eighteenth-century colonies, but at the same time I reject their conclusion of the decreased importance of the seventeenth century in American religious (or political) history.

Studies in Protestant theology continue to provide valuable insights in updating our understanding of the interplay of the tenets and practice of the various Protestant faiths, particularly in the Early Modern period. Diarmaid MacCulloch's The Reformation: A History (2003) provides the most up-to-date global overview of Protestant history through the founding of the New England colonies. For the more specific theological history of New England, E.

17 For a narrative of this transition, see Cohen. 
Brooks Holifield's work, especially Theology in America: Christian Thought from the Age of the Puritans to the Civil War (2003), is the most comprehensive. He is unique among religious historians in tracing, through theology rather than social history, a "persistent Calvinism" through the mid-nineteenth century. Holifield acknowledges that current American religious history has moved away from the history of ideas toward more affect-based "lived religion" but warns that theology played a major role in early American discourse. Other key sources for understanding the Puritan project as a continuation of Reformed Protestant ideas in England and Europe are Stephen Foster's The Long Argument: English Puritanism and the Shaping of New England Culture, 1570-1700 (1991) and the work of David Hall, who never ceases to point out in New England Puritan theology "the flexibilities of meaning that inhere in terms such as covenant" (67).

As religious historians' interest in covenant theology and other Puritan concepts waned in the 1970s and 80s, Robert Bellah (re)introduced the term "civil religion" into the sociological approach to religion and politics with The Broken Covenant: American Civil Religion in Time of Trial (1975). A self-described "jeremiad," Broken Covenant directly references the Puritan covenant motif in a call to reclaim American religious tradition from "utilitarian individualism." ${ }^{18}$ Bellah's work sparked an industry of attempts over the next two decades to identify the existence, terms, and doctrines of America's civil religion. In Broken Covenant, Bellah identifies key documents such as the beginning of the Declaration of Independence as the "superstructure" of American civil religion's external covenantal "shell" establishing "suprapolitical sovereignty" of "a distinctly biblical God" who "creates individual human beings

18 If Broken Covenant is Bellah's jeremiad, one can read his later coauthored books Habits of the Heart (1986) and The Good Society (1992) in the Puritan tradition of covenant renewal literature. 
and endows them with equality and fundamental rights." This shell, however, must be filled by a "public theology" originating in civil society (174-5). Bellah's vision has been very influential to both our current understanding of a "national covenant" as a higher political calling —a sentiment that appears with periodic regularity in political speeches and op-ed columns-as well as our historical understanding of the Puritan covenant; Bellah's idea of civil religion has been called, semi-accurately, "at bottom an ecumenical version of covenant theology" (Kranmick and Moore 170). As such, his and derivative views in the field of sociology have had a tremendous influence on current popular understandings of covenant in the national context.

In philosophy, and more particularly in the interdisciplinary field of critical theory, a "turn to religion" was identified by many critics and a few adherents to post-structuralism in the 1990s, and that movement, as such, can now be found (re)deployed under broad terms like "political theology" and "post-secular" studies. Political Theologies: Public Religions in a PostSecular World (2006), edited by Hent de Vries and Lawrence Sullivan, provides the most up-todate readings in this area. Quickly discounting the idea that Enlightenment secularization successfully shifted religious ideas into the sphere of private devotion, the editors claim instead that "religion's persistent role" in politics leaves secularist political theory in the lurch for a conceptual framework to understand this persistent position. ${ }^{19}$ As religion has always already been part and parcel of the "theologico-political," de Vries calls for a "collective effort, aided by intellectual tools and interdisciplinary methods and inquiries that ... reach beyond the equally urgent interrogation of pragmatic issues in the politics of the everyday" (x). My study of the covenant seeks to add to this critical effort.

\footnotetext{
19 "Post-secular" is to be understood situationally rather than chronologically, not as a return to a religiosity that has been absent but as a return to an awareness of religion which was always already present.
} 
Post-secular studies, in general, draw from post-structural (and otherwise designated) theorists who posit an interrelationship, even an overlapping, between religion and language, either through the originary logos of rhetoric (Paul de Man, Kenneth Burke), or the indeterminate aporetic yet generative abyss of differánce (Jacques Derrida), or the traumatic encounter with language which creates endlessly conflicting desire that must be spoken through a death-like structure eerily similar to prayer (Jacques Lacan, Slavoj Žižek). This identity does not deny the necessary elements of either literary criticism (texts) or theology (God), but instead leads to a cross-contaminated approach to meaning and interpretation, to the understanding of ideas that cannot be relegated to mere historical approaches. Slavoj Žižek's application of split subjectivity to "materialize" political theology, in particular, provides the best theoretical assistance to understanding the conflicting nature and progress of the covenant concept in early American religious writings. Thus, I hope to demonstrate that theorizing the theological, through use of post-secular theorists, particularly Žižek, will provide a useful framework for understanding such a complex theologico-political concept as covenant.

Finally, studies of the religious context of early American literature have focused in the past on elucidating what Thomas Holbrook calls the "American habit of typology" as well as social forms of religious expression. Bercovitch and other critics have done much to generate an aesthetic appreciation for this mode of Puritan/American thought. I seek to broaden this literary appreciation for early American writings by reconnecting the theological concepts so important to the seventeenth-century settlers with the mature nineteenth-century political and moral systems of thought that form the basis for our self-conscious American literary traditions. 


\section{Notes on Methodology}

In general, I read "covenant" as a literary "speech act" in the sense J. Hillis Miller has given to the term: "a performative that troubles the difference between real and fictional, literal and figurative" (qtd. in Redfield 133). Covenant likewise troubles the difference between the material and the spiritual, the political and the religious, in ways that are in turn both troubling and enabling to a politically progressive agenda. I will interpret the term's function and modulating conceptual matrix through early American Puritan church "relations" and disputes, Jonathan Edwards's Freedom of the Will, and Ralph Waldo Emerson's essays, providing historical, intellectual, and theological context as needed.

More experimentally, I also wish to develop upon Harold Bloom's concept of "religious criticism," most fully described in The American Religion: The Emergence of a Post-Christian Nation (1992), to apply literary critical methods to religious literature and concepts. However, I hope to avoid his avowal, following Sydney Ahlstrom and the recent trend in religious history, that the true "American Religion" is "post-Protestant" and starts spontaneously in the nineteenth century with its greatest theologian Emerson leading the way toward new denominations focused on divine immediacy and self-idolotry. ${ }^{20}$ Instead, I will attempt to fulfill the function of criticism to, as Bloom puts it, "build bridges across gaps" (35), and do my best to re-span the emerging gulf between Emerson and his covenanted forebears.

However, one must guard against leaping too precipitously over the gap. My argument will generally be aligned with "post-secular" theorists who argue that we have never in fact been post-religious. There is a danger here in finding my argument similar to certain self-described

20 For Ahlstrom's use of "post-Protestant," see the introduction to his influential A Religious History of the American People (1972), titled "American Religious History in the Post-Protestant Era." 
"counter-cultural" statements about the fundamental religiosity of the United States' "Founding Fathers" and their institutional offspring. Miller accurately stresses that an "organic evolution of ideas" and "direct line of intellectual descent" is based on "a silly version of how ideas get transmitted."21 Such an oversimplified approach is exemplified by David Gelernter, whose work is representative of not a few books coming out of Christian Right think-tanks: "Puritanism turned into the American Religion, and it survives today in this altered form" (9, his emphasis). Though I can't help but be sympathetic to the reclamation of the Puritans in explaining America's religious and political self-conception, Gelernter's Puritans are nearly as unrecognizable as Vowell's — cartoon creatures useful for whatever passes as political ideology in the popular press. Claiming, within a particular conceptual framework, that we are all affected by Reformed Protestant thought is not to say this is a good thing, and certainly not an easily deployable political concept. I see my reading of the covenant concept as clinical rather than prescriptive, and serving a self-reflectively progressive rather than naïvely regressive (or progressive) political agenda.

Something also needs to be said concerning what has come to be called "American exceptionalism," a term more often used as an electoral weapon than analyzed as an historical construct. While I do claim that the New England Puritans enjoyed a unique opportunity among contemporary Reformed Protestants to develop and try to practice a religious and political polity largely free of external institutional pressures, I do not claim the result of this "experiment" to be in any way ideologically pure — quite the opposite—or even readily classifiable. I do not want to (re)establish an originating metaphor of American pluck to place beside our notions of frontier

${ }^{21}$ Admittedly, Miller would probably have considered post-structuralism, and certainly Žižek's ideas, as equally "silly." 
individualism or democratic instinct. When we say Americans are (or are not) an "exceptional people" we make a distinction with only a difference, thinking our ideological heritage is unique when it is merely distinguishable from others', and thus we often miss opportunities to examine the historical dynamics of using and surpassing (or discarding) past ideologies in order to arrive at current ones.

Instead, I propose that we would be better served calling the common thread running through both popular and academic treatments of the influence of early American ideas on modern thought one of "supremacy" rather than "exceptionalism." I wish to suggest with this term not just the dangers of group supremacy (e.g., "white supremacy") but also the political and religious supremacy of authority based on the concept of sovereignty (e.g., "royal" or "papal supremacy") that can be generally derived to any "[s]upreme position in achievement, character, or estimation" (OED, "supremacy"). ${ }^{22}$ Many intellectual histories, both popular and academic, use as their primary vantage point the arrival at modern democratic liberalism as a sort of teleology or destination for intellectual history. Thus, the obvious supremacy argument in, say, the subtitle of Kevin Phillips's book on early American religious warfare, The Cousins' War: Religion, Politics, \& the Triumph of Anglo-America, can also be read in Weber's thesis of the superior economic performance of Protestants over adherents of other faiths. We can discern a more subtle form of supremacy in Miller's description of Edwards's near-spontaneous Enlightenment epiphany or Miller's more general desire to track America's twentieth-century "power" in an arc of ideas from seventeenth-century New England to Emerson, as well as derivative attempts by religious and intellectual historians to explain (or deny) how modernity

22 "Sovereignty" is a key theologico-political concept that will need to be unpacked, especially in the relationship of covenant to the complications of mutual obligation in the spiritual and temporal realms. Kenneth Burke's term "perfection" may also be useful here- he uses the term to mean "ultimate fulfillment," and he also intends the religious (and possibly Emersonian) overtones (70-74), some of which are explored in chapter 4. 
emerged from the archaic crucible of Puritanism. More specifically, we must be wary of studies showing a direct lineal descent from the Puritan covenant to American constitutionalism, though such arguments (and their more numerous detractors) need to be seen as part of the history of the covenant idea. The critical mode of literary analysis will be useful in this regard, as it does not lend itself easily to supremacy arguments; literary traditions can be identified and historicized, but they are rarely viewed as progressing chronologically toward a "more perfect" ideal. In fact, by reading through a literary interpretation of the covenantal framework the admittedly supremacist attempts by the Puritans to be counted as among the Elect, by Edwards to protect God's sovereignty from human self-determination, and by Emerson to differentiate "Man Thinking" from conformist existence, we can see openings for true (if impossible) equality begin to appear.

Nor will I go in the other direction and seek to (merely?) historicize the Puritans and contextualize the "covenant" within their conceptual universe. Though familiarization of historical context is, of course, vital for any study of early modern literature, it is not the only framework within which such texts must be read. Rather than saying that New England Puritans believed in such-and-such which comprised something called (by us, not them) "covenant theology," or that the concept of the covenant through direct genealogical filiation begat the American Constitution, I seek to demonstrate that the covenant concept in early American literature is a complex theological idea that resulted in complex and contradictory cultural and political ideals - i.e., equality guaranteed by fundamental inequality, as read through the identities and tautological constructions in the literature.

Despite my desire to be comprehensive in the study of the covenant concept, there are 
many important uses of the covenant idea that I will not be able to investigate. Most markedly, I will not delve into the serious impact the Reformed Church of Scotland, widely known as "the Covenanters" for ascribing to the Solemn League and Covenant of 1643, had in shaping the Church of England, as well as on subsequent American settlement. ${ }^{23}$ Nor will I include much study of the Dutch Reformed Church, even though the Netherlands were formative to the New England project not only for providing safe haven to premier covenant theologian William Ames and the Plymouth separatists but also as the site of the 1619 Synod of Dort; additionally, there were many intriguing interactions between the New England and Dutch New York colonies. ${ }^{24}$ Neither will I do much to compare the New England notions of the covenant to that of their sympathetic contemporary Reformed countrymen, from John Milton and Oliver Cromwell's famous musings on the covenant, to the less well-known Puritan colonists of the Caribbean island Providence, ${ }^{25}$ whose experience with inequality in the form of slavery makes it comparable to that of their South African Reformed brethren. Finally, the particular use of the covenant concept by the Church of Jesus Christ of the Latter-Day Saints will have to be neglected, though I would guess that a tangential look into its use by the most American of religions would be very fruitful. These alternate pathways for the covenant concept, while important in shaping its Early Modern and contemporary meanings, are not integral to my thesis and must be left to a later time.

Finally, though much will be said in this study about religion and theology, I will be speaking from the vantage point of neither a believer nor a skeptic. Rather, I will argue that we

23 For an overview, see Reid.

24 The Dutch Reformed Church also more recently gained notoriety for its relationship to South African apartheid, as memorialized, historicized, and romanticized in James Michener's popular novel The Covenant (1980).

25 See Karen Ordahl Kupperman, Providence Island: The Other Puritan Colony (1993). I recently discovered a personal connection to these "other" Puritans through my father's family, which is originally from Old Providence. 
are all, "in the American grain" to use William Carlos Williams's trenchant phrase, religiousProtestant, specifically. Our thoughts and beliefs are interpenetrated by vestigial aspects of Reformed theology, achieving the same impact on our permanent cultural paradigm as slavery, imperialism, cars, or any other matrix of ideas and experience without which our definition as a culture is not possible.

\section{Overview}

In my first chapter, I lay out the tools of literary critical theory which I employ in reading early American texts. I provide an overview of various recent attempts to integrate theology and theory, from the postmodern and negative "death of God" theological movements to the "theological turn" of post-structural and post-secular theory, particularly in the late writings of Jacques Derrida and recent work by Slavoj Žižek. I then attempt to identify a counterintuitive direction of these conceptual projects, particularly Žižek's, toward a materialist theology that relies on as well as informs the Reformed Protestant covenantal theology of grace and works.

Building on this theoretical framework, the second chapter begins by establishing the important place of the covenant concept within Reformed Protestantism, and how this concept was translated into political practice in the North American English colonies. The New England Puritans developed the covenant concept into a complicated architecture that incorporated the relationship not only between God and humanity but also within the Godhead and as the basis for the formation of churches. Using the church membership relations recorded by Thomas Shepard and the Ann Hutchinson court trial transcript, I demonstrate how this inherently unstable theological concept created unintended slippage between God's grace and mankind's works, 
resulting in a theological formulation remarkably open to Žižek's analysis of political ideology.

Moving into the eighteenth century, the third chapter demonstrates how Jonathan Edwards converted the concept of the covenant from a more outwardly instituted, if inwardly positioned, form of church polity to a more inwardly instituted, if outwardly consecrated, comprehensive surrender to radical grace. This move, I argue, creates a subtle internalization of the equality-under-inequality covenantal relationship best expressed in Edwards's ingenious counter-argument in Freedom of Will for a deterministic and materialist foundation for human liberty. In the end, Edwards unconsciously provides a firm theoretical foundation for the uneasy but necessary alignment of the covenants of works and grace, releasing the subjunctive potential of grace to work through history as a predeterminer of meaning and (we hope) of freedom.

In my final chapter, I argue that Ralph Waldo Emerson completes the conversion of the covenant from a politically conceptualized theological framework for radical grace into a personal institutionalization of grace itself. Rather than giving himself over to God's grace without mediation, like the early Antinomians with whom he identified, Emerson instead internalizes the radical nature of grace itself as a full expression of his own freedom. I use Stanley Cavell's exploration of Emerson's development of America's "moral perfectionism" (in part through a perfection of one's "constitution") in light of the covenant motif. Emerson both celebrates and at the same time tries to regularize the covenant into an alternate conceptual framework, a new personal-political "constitution" of individual self-determinism. This framework, I argue, is just as deterministic as the old covenant that still holds sway in America's self-conceptions of personal liberty and civic equality. 


\section{CHAPTER 1: THE UNCONSCIOUS COVENANT}

Lacan's "God is unconscious" should not be confused with the opposite Jungian New Age thesis "the Unconscious is God" ... Lacan's "God is unconscious" reveals the fundamental Lie that constitutes a person's fantasmatic unity: what we encounter when we probe the innermost kernel of our being is not our true Self, but the primordial lie ... secretly, we all believe in the "big Other."

$$
\text { Slavoj Žižek, "Forward", 1xxi }
$$

In the above passage from the second edition of For They Know Not What They Do (orig. 1991), Slavoj Žižek attempts to clarify one of his (or Lacan's) central theses on ideology: the "big Other" (aka God) does not exist, and yet modern subjectivity is based on the unconscious-asbelief in the big Other. Žižek uses this fundamental negativity—-the belief in a nonexistent God cementing all communal meaning — to explain a paradoxical line from popular anti-religionist Christopher Hitchens's analysis of North Korean politics: "[M]ass delusion is the only thing that keeps a people sane." Ironically, Žižek claims this as "arguably the most succinct definition of ideology"; it is doubtful that Hitchens would enjoy having his words used to explain how "we all believe in the 'big Other'," that we all continue to participate in the primordial lie.

To point out the distance between the intent of Hitchens and Žižek's observations — as it happens, roughly one year either side of $9 / 11$ - is also to point out the distance between these two avowed atheists' views on religion. For Hitchens, religion is simply a destructive ideological 
bugbear that needs to be exposed and rooted out so that enlightened society can move on. For Žižek, religion, and Christian theology in particular, provides a theoretical source for understanding and countering current ideological deployments within our supposedly enlightened society. One must, Žižek claims, embrace "the necessity of risking a materialist appropriation of the religious tradition" ("Forward" 1).

A particularly Žižekian way to see the connection between this appropriation and the American religious tradition we are concerned with in this study is to repeat a joke Žižek tells in the same essay: A rabbi pleads with God for assistance in dealing with his bad son, to which God calmly replies, "Do what I did: write a new testament!" (li). The butt of this particularly blasphemous joke is not the rabbi but God himself, and by extension Christianity, in that it poses the "new testament" (covenant) as solving the problem of a "bad son" by using his death to save mankind - in other words, the new testament/covenant was created to address a completely separate problem, making one's salvation incidental, even accidental. This seemingly unnecessary supplement—was there really anything wrong with the "old" testament or covenant? is the new covenant actually new? — establishes an ironic basis for Žižek's appropriation of the Christian and, more particularly, the Reformed Protestant theology of grace as a radical and inherently unstable concept that is, at the same time, central to theology's field of meaning. Matthew Sharpe defines Žižek's theory of "sublime objects," in the context of his response to 9/11, as necessary to creating a hegemonic ideology as "precisely objects that no interpellated subject can ever quite place in the fabric of his/her usual phenomenological self-experience, and yet which are taken by them to be what give meaning and unity to this entire field" ("Sociopolitical Limits of Fantasy" par. 6). This can be taken not only as a launching point for an 
ideological analysis of 9/11 but also as a precise description of Reformed Protestantism's use of the covenant concept in its theology of grace—a sublime, fantasmatic yet highly structured concept used to unify and organize an ultimately radical and anarchic ideal.

In this chapter, I will provide an overview of Žižek's use of Christian theology in his philosophical project of interrogating contemporary ideology. In doing so, I hope to perform a reversal and to demonstrate how Žižek's theorization of theology can help us better recognize the structural impact of "mainstream" Reformed Protestant theology, particularly the theology of the covenant, on early American literature. As Rex Butler argues, Žižek's preference for Christianity over Judaism has less to do with content than with form. Specifically, Christianity performs "a kind of permanent doubling that at once means we can never entirely say what Christianity is and we are always being judged according to it" (111). In other words, one can never stop acting as if one believes, even though one's belief relies on an empty set, the non-existing "big Other":

It is not a question of how our belief intervenes in an already existing field of acts, but of how acts themselves are not possible outside a certain belief. There are only acts, but this only because of belief - a belief that is not an exception to these acts, but precisely what renders them 'not-all'. (112) This theoretical necessity of belief as an "indivisible remainder" prefiguring action provides a useful context for reprising the Reformed Protestant debate concerning the covenants of "works" and "grace." As we will see, Žižek's interpellation of idealism and materialism highlights the conflicts at the core of Reformed Protestant polity—especially at the historical moment and location of its "fulfillment" in political form in New England. In other words, the most unsettling aspect of the Massachusetts settlements was the opportunity to put beliefs into action. 
Žižek theoretical work is perfectly positioned to capture the long-standing structural, political, and ethical implications of the Puritan "project" in New England-implications that extend to this day. As Sharpe points out, Žižek specifically creates an opposition not versus Judaism but against contemporary postmodern cynicism ${ }^{26}$ in Christianity's insistence on doing one's duty (Žižek's interpretation of Paulinian agape) regardless of the impact on one's sense of self, or even on one's salvation (Slavoj Žižek 250). Likewise, Žižek asserts that true human community, enacted through the death of God in the Holy Spirit, resides in the fact that, as Jeffrey Nealon puts it, "[w]e share impasses and problems rather than any number of ideologically suspect positive characteristics like national, ethnic, religious, or intellectual 'identity'" (600). Gustavo Guerra, writing about Žižek's notoriety on the academic scene, expresses surprise at Žižek's fame: "There is nothing in his works that should be particularly appealing to an American critical or philosophic mentality." Nevertheless, Guerra identifies a certain "pragmatic oeuvre" in Žižek's work, in that he puts theory "to work" (21).

Žižek, one could say, is an ardent proponent of the covenant of works, in that he argues for belief as the result rather than the cause of religious and moral activity. Following Pascal, Žižek claims that "rituals engender an inner conviction" (Myers 68). This is not only a direct challenge to the covenant of grace theology expounded by Reformed (and all other) Protestants, but it exposes a problem within the theology of predestinarian grace itself-namely, grace is, by definition, determined by God's activity of determination. God is, in essence, forced to choose, has no choice but to do so, and no basis either, other than the ability itself to do so. To draw on Žižek's expounding of Schelling's originary "abyss of freedom," God brought all into being through the madness of the act of creation, and such an act can be seen as the primordial

26 A good example of such would be the work of Sarah Vowell, briefly discussed in the introduction. 
destruction of freedom, God's and ours alike. In an exact sense, Žižek suggests, none of us are ever free to go home again:

[T] he only way really to account for the status of freedom is to assert the ontological incompleteness of 'reality' itself ... It is only this gap which accounts for the mysterious 'fact' of transcendental freedom.

(Totalitarianism 174-5)

This "gap" in reality creates the chaotic freedom of both God and ourselves possible. And, emphatically for Žižek, this possibility is at the heart of true materialism, requiring the appropriation of the religious tradition in order to make this "fact" of materialism apparent; like in the joke, which suggests God had alterior motives for creating the scheme of Christian salvation, the purpose of Žižek's materialist reading of Reformed Protestant theology is to better understand materialism.

Žižek suggests that the revolution of Christianity is its early and enforced admixture of idealism and materialism, in which it "offers Christ as a mortal-temporal individual, and insists that belief in the temporal Event of Incarnation is the only path to eternal truth and salvation" (Totalitarianism 151). This belief, due to its very lack of structural conceptual coherence, can only be rooted in the unconscious of the adherent. Here we get to the major interstitial point for Žižek's psychoanalytic theory and politics proper, "knotted" around the externality of the unconscious. The unconscious, Žižek claims (following Lacan), "is not 'deep inside'" but "outside, materialized in the state apparatuses ... What subverts my conscious attitudes are the implicit ideological beliefs externalized, embodied in my activity." Žižek uses the term unconscious "in the sense of the set of presuppositions, beliefs. The subject is not aware of these 
beliefs, but the beliefs are materialized in the social practices, rituals, institutions in which the subject participates" (Žižek \& Hanlon 5-6). Thus, analysis of ideology is best performed on "external materiality" rather than the "explicit formulation of ideology"—-hence Žižek's employment of the X Files motto, "The Truth is Out There," to illustrate "the analysis of the inherent antagonisms of an ideological edifice" through use of popular culture ("Fantasy as a Political Category" 15, 77).

There is a direct connection between Žižek's counterintuitive psychoanalytic setup of the unconscious and the troubled opposition between the covenant of grace and the covenant of works in Reformed Protestant theology: one's "inward" spiritual status is exemplified by one's external deeds, but one cannot be saved by just doing good deeds; rather, the good deeds (if that is what they are) are a materialized embodiment of one's predestined election. The scandal of the covenant concept in relation to grace is that it is a conscious externalization-a juridical, legal framework - for an unconscious predestined status. Grace is unconscious both "literally" (the Elect should never deign to know the mind of God, no matter their certainty of election) as well as psychoanalytically in that, as I shall demonstrate, the structure of grace as (incompletely) mediated by the covenant directly parallels the Freudian unconscious.

What we propose to do here is not so much psychoanalyze the New England Puritans as the history of their theological concepts—and our own. I share Žižek's suspicions of other theorists' (Butler, Laclau) claims that the essentialism of the past is now disintegrated. Bluntly, Žižek asks "why were people one hundred and fifty years ago essentialists? Were they simply stupid?" One might ask the same question for people living four hundred years ago. ${ }^{27}$ A central

27 David Castillo sees a benefit to analyzing colonial—here, Brazilian—literature through Žižek's idea of "surplus," the indivisible remainder of the Real that escapes symbolism, most often showing itself "in the form of unsymbolizable materials and epistemological inconsistencies" (15). 
concern of this study is to avoid such a "teleological narrative" of evolution from historical essentialism toward modern rationalism and performative freedom, and to treat the historical sources theoretically "on their own terms" or, to slip into Lacanese, based on their own Real. "Each historical epoch," Žižek says later in the same interview, "has its own Real. Each horizon of historicity presupposes some foreclosure of some Real," defined as "that on account of which every norm is undermined" $(14,16){ }^{28}$

\section{Theology and the Political}

Žižek is one of the few theoreticians who treats theology and politics "at once" and does so by employing theological categories of meaning to get at theoretical "truth." In this way, his theoretical work is useful in studying the theologico-political concept of the covenant, which directly co-implicates the theological and the political.

This is not always a comfortable fit. ${ }^{29}$ Adam Kirsch accuses Žižek of using "religious tropes" without believing in religion (33), Vincent Cannon registers concern with Žižek's admitted proximity to Protestant predestinarian logic (215), and Claudia Breger strongly argues that Žižek develops his own Gnostic political theology which "outlines a world eternally ruled by a monstrous, earthbound Lord, a world not open to human agency and political change" (75). ${ }^{30}$

28 There is also a danger here of falling into the literary study "star system"—another form of essentialism —in which, as David Shumway aptly describes, "one finds article after article in which Derrida or Foucault or Barthes or Lacan or Žižek or Althusser or Spivak or Fish or Jameson or several of the above are cited as markers of truth. It is common now to hear practitioners speak of 'using' Derrida or Foucault or some other theorist to read this or that object" (95). I prefer to adapt how Žižek describes his use of Lacan, and say that in this study Žižek's "theoretical apparatus is simply put to work" (For They 3).

29 Many critics, including the ones cited below, openly accuse Žižek of anti-Semitism (and, to a lesser extreme, anti-Buddhism). Žižek has responded, emphatically and in detail, to each and every accusation in his books as well as in periodical rejoinders, including the following: "The Rhetorics of Power" (response to Breger), "I Pleady Guilty--But Where Is the Judgment?" (W. D. Hart), and "Disputations: Who Are You Calling AntiSemitic?" (Kirsch).

30 Žižek's responds to Breger ("Rhetorics of Power") by quoting himself:

[I]t is the very focus on the notion of Real as impossible that reveals the ultimate contingency, fragility (and 
Others, such as Eric Santner, appreciate Žižek's ability to identify "the importance of theological categories and traditions for the analysis and critique of politics and ideology" (206). Žižek's political theory rests on the combination of Lacanian subject as void, Marxist political economy, and "Pauline materialism" defined by Robert Boynton as "St. Paul's conviction that universal truth is the only force capable of recognizing the needs of the particular" (50). Žižek derives this latter Pauline identity of materialism and universalism directly from the work of Alain Badiou, in particular his groundbreaking work, Saint Paul: The Foundation of Universalism (2003), in which Badiou establishes St. Paul as "an antiphilosophical theoretician of universality" who creates a community of universally singular individuals under the "evental grace" of Jesus's crucifixion and resurrection, which then constitutes all believers as equals (63). From this appropriation of Christian universalism, Badiou is able to "extract a formal, wholly secularized conception of grace," what he later calls "a materialism of grace," based on "the strong, simple idea that every existence can one day be seized by what happens to it and subsequently devote itself to that which is valid for all" (66) — an ideal that, as we shall see, is supremely Emersonian. ${ }^{31}$

thus changeability) of every symbolic constellation that pretends to serve as the a priori horizon of the process of symbolization. (Butler, Laclau, \& Žižek 221, his emphasis)

In other words, the impossible Real stands as the arbiter and guarantor of possibility of transcendental freedom, similar to how the unequal "big Other" stands as the arbiter and guarantor of equality. Žižek simply accuses Breger of disavowing the Freudian unconscious, the basis (if it can be called such) of psychoanalysis ("Rhetorics" 96); however, we might add that Breger and Žižek's many other critics quite extravagantly miss his focus on the real conflictual nature of political agency itself, instead of engaging in academic theoretical performatives, virtual insurrections, and the like.

31 Badiou's attribution of "truth's status as a universal singularity" aligns, as we shall see, with Emerson's attempt to create a universally singular "Man" (22). Badiou defines St. Paul's "antiphilosophy" in light of what Reformed Protestant theology calls "irresistible grace" (introduction; chapter 2), the sudden rupture of the subject onto the scene (aka the event) through faith, likening Paul's "conversion" on the Damascus road to "a conscription instituting a new subject" (17). However, one might say that Badiou aligns himself too closely to the "antiphilosophical" covenant of grace as event as opposed to works as law. This is similar to claims made about Emerson that Stanley Cavell seeks to dispel, as described in chapter 4, seeking instead a beginning to philosophy in its never-ending attempt to end itself. Badiou does connect the effect of the event, the arrival of Jesus as "the name for what happens to us universally," as the arrival of a radical equality "of belonging together to a work" (60). This "work," however, is in the form of a "universal thought" leading to the "production of equality," which 
When Žižek moves from theology in general to the particularities of Protestant theology, he relies heavily but strategically on Max Weber's sociological synthesis of early Protestantism and proto-Capitalism. ${ }^{32}$ In his essay "Lenin Shot at Finland Station," for example, Žižek cites Weber's thesis in The Protestant Ethic as "the central ideological paradox of modern history": In contrast to Catholicism, which conceived of human redemption as being dependent on good deeds, Protestantism insisted on predestination: why then did Protestantism function as the ideology of early capitalism? Why did people's belief that their redemption had been decided in advance not only not lead to lethargy, but sustain the most powerful mobilisation of human resources ever experienced? (par. 2)

The paradox is more critically employed in an earlier essay on ideology, where Žižek cites those who identify the Weberian "Protestant ethic of hard work as an end-in-itself" as having a limited impact on a small number of "emerging capitalists," and therefore as not being responsible for an entire societal shift. However, he then critiques those who prioritize modern non-ideological power mechanisms over the dissipated and widespread media-generated and dispersed ideology of today. In the end, thematically picking up on Derrida's theme, ideology remains as a "spectre" of and thoroughly co-implicated with material reality—it is "the spectral apparition that fills up the hole of the real" ("The Spectre of Ideology" 14, 21).

Protestantism, as Žižek rightly asserts, is an ideological paradox, one that he could not help but be attracted to. Weber, for his part, through his secularization thesis most often associated with the word "disenchantment," provided a sociological touchstone for theories of

\footnotetext{
is the same as the production of the subject, defined as "he who maintains the universal, not conformity" (109). 32 See above introduction for a brief discussion of Weber.
} 
the declension of religious belief in the West. ${ }^{33}$ As Anthony Carroll explains, Reformed Protestantism (Calvinism) is practically identified with this disenchantment:

For Weber, the process of the disenchantment of the world, which began in the prophetic tradition of ancient Judaism, had reached its historical fulfillment in Calvinism, which, in his view, presented the most consistent religious form of rejection of the sacramental mediation of salvation. (87) The process toward disenchantment is both theological and political, as the ancient Judaic political modification to leadership by prophets_-identified by Weber and other biblical scholars to the covenantal mode-is matched by the supposed self-rule of the Calvinists, alone before their God in the hope of salvation. Weber, as characterized by Carroll, "understands Protestantism to have played both a theoretical and practical role in the rationalisation of the world" (100). Protestantism leads to its own disenchantment; disenchantment is written in, so to speak, to Protestantism itself. As I will show below, this is a theme that plays out over and over in the "Death of God" and deconstructive theological literature-Western Christianity, and Protestantism in particular, as the source of its own undoing. Žižek in many ways replays this theme, but adds what I will argue is a different aspect: the materialism that is endemic to the (undoing of the) theology of grace.

However, one should also understand the secularization of Protestantism as represented by Weber as a change in form rather than in content. Fredrick Jameson, in a lucid analysis of Protestant Ethic, uses narrative analysis to describe how, in Weber's hands, religion "ceases to be felt as an ultimate end or value in its own right"— that it becomes, instead, a means through which to understand reality. "Thus," Jameson concludes, "paradoxically religionalization

33 For the latest uses of and updates to Weber's theory of secularization, see Martin, Pecora, and especially Asad. 
becomes itself the principal agent in the process of secularization as a whole" (21). ${ }^{34}$ Calvinists didn't all of a sudden become capitalists, but instead created a particular ideological framework for capitalism, one that we call "secular" but which is still based on theological conceptual structures such as the covenant.

Žižek takes this argument a step further, especially in his materialization (if not secularization) of the theology of predestination by returning to the form of Christianity as opposed to the ends of "religion." As Gil Anidjar points out, terms such as "religion" and "the West" were created by Protestant Christianity to distance or "liberate" itself from itself, and thus "reincarnated itself as secular." To study the source of American ideologies—religious, political, secular or otherwise - requires not just a return to the Puritans but a return to the historical process of Christianity as a secularizing concept for particular ends, a concept even more than a practice. We must rethink "religion" as specific to Western Christianity—and, I would argue, in the context of American thought, Reformed Protestant Christianity—as a predestinator of modes of the secular, including critical theory. In a very literal way this means "coming to terms" with our understanding and expression of American thought, religious and/or otherwise.

\section{Deconstruction and/as Religion}

In Cannon's review of Žižek's The Fragile Absolute, or, Why Is the Christian Legacy Worth Fighting For? (2000), he mockingly situates the book within a general "turn to religion" within critical theory where "the prospect of the reproduction of the doctrinal and exegetial disputes of Reformation theologians in contemporary Marxist thought is as amusing as it is

\footnotetext{
34 Religion not only survives modern secularization but in fact shapes its progress. Jameson calls this intuition "the 'religionalization' of means, which is, it seems to me, the central and most original aspect of Weber's argument."
} 
obscene (are we to be faced with the task of critiquing doctrinaire, 'vulgar' Augustinian scholastics or radical antihumanist Paulines?)" (203). Our answer can only be, in proper Žižekian form, "Yes, please!"

Critical theory has had a rich interaction with religion in general and theology in particular. First identified by Dominique Janicaud in 1991 and expanded on in Hent de Vries's Philosophy and the Turn to Religion (1999), the scope of this interaction between Continental philosophy and radical forms of theology has engaged many critical theorists, but none more than Jacques Derrida. ${ }^{35}$ Derrida's early and sustained engagement with the deconstruction of "ontotheology" was quickly supplemented by a continuing debate on the merits of understanding deconstruction itself as a form of apophatic or "negative" theology. ${ }^{36}$ Theologians such as Robert Scharlemann, Carl Raschke, and Charles Winquist were quick to pick up on the theological implications of deconstruction and apply its focus on language to the practice of theology itself, namely writing about God; these and other theologians also made valuable connections between deconstruction and postmodern theologies, especially Thomas Altizer's earlier formulation of "Death of God" theology in the 1960s. ${ }^{37}$ Winquist, in particular, was emphatic about the connections between deconstruction and theology: "Theology has a deconstructive agenda and deconstruction has a theological agenda" (qtd. in Scharlemann 39). Cultural and religious

35 For a useful summary as well as critique, see Bradley, "Derrida's God: A Genealogy of the Theological Turn" and his intriguing argument that Derrida himself effected the "theological turn" in Continental philosophy through his unnecessary use of religious and transcendental terminology in his later writings (an argument with which Žižek sympathizes_-see "A Plea for a Return to Différance").

36 Among the many works on this subject, see Coward, Foshay, \& Derrida (1992), including Derrida's most sustained engagement on the topic, "How to Avoid Speaking: Denials" (first published in French in 1987); de Vries, Philosophy and the Turn to Religion; and Bradley, Negative Theology and Modern French Philosophy for supportive and critical summaries, respectively.

37 For just a sampling of the many works on this subject, see Scharlemann, Raschke, Winquist, and Altizer. Winquist on the need to marry deconstruction to theology through language: "We need a deconstruction in theology to see how theological discourses are constructed so we can assess the practice of theology with regard to the range of its effective action" (82). 
theorists such as John Caputo, Kevin Hart, and Mark Taylor were equally excited about the possibilities of developing new deconstructive theologies either directly from the work of Derrida (Caputo), through a return to negative theology (K. Hart), or by way of a synthesis between Death of God theology, deconstructive textuality, and postmodern art (Taylor). ${ }^{38}$ The result is a body of work that mixes a confessional linguistic exuberance with the challenging formulations of critical theory; one either finds it inspiring or barely readable. ${ }^{39}$

However, the focus of all these syncretic efforts to cross-pollinate (or contaminate) deconstruction and theology remains on Derrida. Derrida, for his part, has refocused attention in his later writings - especially Politics of Friendship (1997), Adieu to Emmanuel Levinas (1999), and Of Hospitality (2000) — on Emmanuel Lévinas's ethical formulations of the Other, the neighbor, and hospitality which have dominated recent critical works on the engagement of religion and deconstruction. Nevertheless, Derrida's less Levinasian work "Faith and Knowledge: the Two Sources of 'Religion' at the Limits of Reason Alone"40 provides his most extensive

38 Taylor is probably the most symptomatic of what Henry Sussman calls "religion's fatal attraction to deconstruction" (198). His "a/theology" is a belief (without belief, of course) that Christ represents the full incarnation of God into the Word. God "dies" by becoming text or, rather, textuality, understood broadly through deconstructive criticism as a universally errant - and, therefore, inherently non-universal - reality that can only be "read" through the play of signification (103 passim). Taylor's mode of theology-cum-textuality naturally lends itself well to the development of a theory of theology for the reading of texts. But Taylor's theology is a theology of texts, and one need not worship texts in order to study them (deconstructively or otherwise). In other words, reading of theological concepts through texts, while requiring a heightened awareness of textuality, does not necessarily require its prioritization as that which is being studied. One can, in a sense, claim a reality or even a truth beyond the play of textuality — one might even say such a claim is by its nature positing an undeconstructible concept, as Derrida does with justice (Acts of Religion 243). While I am in no way claiming that covenant or grace are undeconstructible, I find the totalizing deconstructive gesture of Taylor's theologycum-textuality too delimiting for an approach to these concepts. Additionally, Taylor's neological appropriation of "mazing grace" (149-69) captures the supposed random nature of grace in the context of Reformed Protestant theology, but emphasizes its relation to the never-ending play of signification rather than its more disturbing and determinate predestinarian implications.

39 For a recent direct engagement with deconstructive theology, widely construed to include Foucault and Rorty, see Michener. One must also mention here the Herculean encyclopedic labors of de Vries, who is probably the one theoretician on course to actually deconstruct religion. See his book-length introductions in de Vries \& Sullivan and de Vries, Religion: Beyond a Concept, the first of a multi-volume project on the subject. Intriguingly, Žižek is not included in either of these volumes; de Vries, however, appears in Žižek's latest coedited collection (Davis, Milbank, \& Žižek).

40 From a talk given by Derrida in 1994; first printed English translation in Derrida \& Vattimo; reprinted in 
treatment of the conceptual (if not theological) roots of religion and fullest elaboration of "autoimmunity" as key to deconstructive religiosity. Likewise, Henry Sussman's unique view of deconstruction as the fourth Abrahamic religion exposes the benefits and detractions of using Derridean deconstruction to understand historical Reformed Protestant theology.

If a purpose could be gleaned from Derrida's essay "Faith and Knowledge," it is to particularize the stakes involved in analyzing religion through the "evil of abstraction" (43) that tends to evacuate as well as instrumentalize religion through its own internal antagonisms. Derrida first distinguishes between religion and other forms of the sacred:

Distinctions are required: faith has not always been and will not always be identifiable with religion, nor, another point, with theology. All sacredness and all holiness are not necessarily, in the strict sense of the term, if there is one, religious. (48)

Having made these distinctions, Derrida draws on the supposed Latin roots of the word "religion" in either legere ("to gather") and/or ligare ("to tie") to point out an "irreducible duality" in the common meaning of a "bond" in these two etymological sources (71-4). The first aspect of this duality is the experience of a "fiduciary," promise-driven, even covenanted communal link, but one that "would precede all determinate community, all positive religion, every onto-anthropo-theological horizon. It would link pure singularities prior to any social or political determination, prior to all intersubjectivity, prior even to the opposition between the sacred (or the holy) and the profane" (55). This pre-communal link Derrida characterizes with two names: the "messianic" call for justice (again, prior to any form of religion per se) which (per)forms the foundation to law; and the "chora," the abstract "place of absolute exteriority

Derrida, Acts of Religion, a more accessible version used for this study. 
"which bears "the thought of that which is beyond being." This place-with-no-place or "desert in the desert" "remains absolutely impassible and heterogeneous to all the processes of historical revelation or of anthropo-theological experience" (56-9) - i.e., it may be at the root of religion, but not of theology.

The second aspect of Derrida's dualistic religious architecture — or foundation, rather, as we have not yet reached religion proper-is the idea of the "unscathed," of pure sacredness or holiness. This second part, brought up but not discussed until near the end of his essay, is associated with the "terrifying but fatal logic of the auto-immunity of the unscathed" and the "religion machine," which closely resembles Žižek's theory of the Freudian "drive" as the heart of the Real:

We are here in the space where all self-protection of the unscathed, of the safe and sound, of the sacred (heilig, holy) must protect itself against its own protection ... against its own immunity. (79-80)

This purity is expressed as both phallic fetishization which "binds the tele-technoscientific machine, this enemy of life in the service of life, to the very source and resource of the religious" (84), as well as the covenantal circumcision "ordeal of the unscathed" which, in turn, binds all Abrahamic faiths together into a "universal structure of religiosity" (84-6).

Together, the double nature of religion creates what he calls a "double bind" with certain potentially violent outcomes, as a belief in purity necessitates a fiduciary promise that sacrifices current (impure) life to a faith in a (pure) holiness to come. This dynamic results in an investment in symbols to "promise" that holiness, which results in the destruction of the "pure" holiness, and the phallic substitution of the unscathed and fully present God-center with a 
"theological machine," a "machine for making gods," impure impostors for the purity of God's full expression. ${ }^{41}$ This "principle of sacrificial self-destruction ruining the principle of selfprotection" Derrida calls "autoimmunity," sacrificing one's own self-presence for one's idea of, faith in, the pure center, "the price to pay for not injuring or wronging the absolute other" (87-8).

We arrive again at (or return to) the necessity of the theological in the political: "The fundamental concepts that often permit us to isolate or to pretend to isolate the political ... remain religious or in any case theologico-political" (63). Political conflict remains a conflict over religious forms of government, of personal and social polity, that are historically, geographically, and culturally specific (specifically, Latin-Anglo-American ${ }^{42}$ ). We also, hearkening back to Derrida's original distinctions, see why Derrida is here speaking (or has already spoken of, or to) religion as opposed to theology. And we can now understand Derrida's "position," stated in the early 1970s, that deconstruction "blocks every relationship to theology" (Derrida, Positions 77) while at the same time agreeing with Taylor that deconstruction is more in line with the death of God than any other contemporary theology (Taylor 6).

It is therefore ironic that Sussman suggests, in one of the most unique and valuable analyses of deconstruction's relationship to religion — as well as to literature - that deconstruction is best considered as an Abrahamic faith in its own right, essentially raising it to the level of a belief system (176). ${ }^{43}$ In a close reading of Derrida's "Force of Law" and "Hostipitality" essaysfound in the same volume as "Faith and Knowledge"—Sussman identifies close and productive

${ }^{41}$ For a close reading of Derrida's use of "theological machine," see de Vries, "The Two Sources of the 'Theological Machine'."

42 "For everything that touches religion in particular, for everything that speaks 'religion,' for whoever speaks religiously or about religion, Anglo-American remains Latin" (66).

43 One is also tempted to suggest that Badiou's Pauline system may be derived into a fifth Abrahamic faith, but that would require a systemization as detailed as Sussman's, only begun by Badiou's eight "theorems" in Saint Paul (81-97). 
ties between deconstruction and religion, to the point that "[d]econstruction assumes the mantle of religion in part through its knowing partnership in an undecidability at the very fulcrum of Western theological core concepts" (190). Deconstruction, as we have seen, both identifies and exemplifies the "theological machine" described by Derrida as the necessary precursor for LatinAnglo-American religio-governmental polity; however, deconstruction also purports to destabilize the machine and have nothing to do with theology. One might ask, wouldn't an Abrahamic faith need a "relationship to theology"? It might seem all too fitting that deconstruction take the place of "Idolatry" in the Medieval schema of the "four faiths"—-the others, of course, being Christianity, Judaism, and Islam (W. D. Hart 555).

Sussman's helpful and, to my mind, all too accurate assignation of deconstruction in the realm of religious thinking, or thinking about religion, also points to the limitations of using deconstructive theory as the mode of analyzing specific theological concepts such as covenant. Sussman's deconstruction is a mode of comparative religious analysis, rather than a mode of reading a religious idea as a political problem that plays out in a particular historical cultural matrix. Sussman points in this direction, but from a vantage point of seeing deconstruction as having already explored the figurative language of the major religions and now can make the hand-off to the social sciences to apply this critique to specific cultural practices:

Indeed, now that deconstruction has sketched out new paradigms for discerning the precipitation of ideologies, morals, and even cultural icons out of canonical or enabling language, the specifications of the effectiveness of this distillation in the world may well have emerged as a pressing overarching mission for the descriptive social sciences. (179) 
However, religious practice is not necessarily born fully formed from the words of timeless theologians, and the process itself of "precipitation" and "distillation" from language to worldly acts has not as yet been fully discerned. Sussman continues:

Deconstruction's scenarios of the precipitation of ideology, metaphysics, and belief out of pivotal keywords and figures should furnish the focal point of social-scientific assessments of organized religion. (180)

This would seem to fully describe the purpose of this study in explicating the "keyword" of "covenant"—-that is, if we were only interested in assessing organized religion. Instead, the "precipitation" of the concept of covenant makes its way through works at once theological, philosophical, and literary and in the end assesses political rather than (or in addition to) religious beliefs. Thus, the hand-off from deconstruction to the social sciences is premature, and may point instead to a deficiency in deconstruction epitomized in its perpetual handing-off, its messianic always to-come-ness built into the theory. ${ }^{44}$

Sussman seeks to point deconstruction's reading of western monotheistic religions "beyond the fold" toward eastern and indigenous faiths; Žižek's theoretical use of Christian theology is pointed instead at the very conflictual heart of western Christianity (180). Sussman also wishes to point to the inherent benefits of Western culture that indwell in its encounter with deconstruction. It might take a bit more faith than credulity to swallow what Sussman says deconstruction "reminds" us of, namely the non-violence at the core of Western culture: "If we insist on imagining Western art, science, religion, and government as a grand edifice, it is founded, irreducibly and incontrovertibly, on non-violence" (207). This grand edifice has been,

44 For Žižek's critique of imminent late-Derrida as opposed to the always-already immanence of Derrida's différance, see "A Plea for a Return to Différance." 
according to Sussman, in an ingratiating but awful understatement, "misrecognized" through actual Western history, which allows deconstruction to come along with a more proper mis- or re-recognition:

If the traditional Western religions and deconstruction communicate at all, it is in the foyer linking shared commitments to a meticulous reading of theology and to the revision of misunderstandings promulgated by prior exegetical lapses, whether blind spots or motivated misrecognitions. (221) In other words, deconstruction allows us to realize what a great metaphysical tradition we didn't know we had, a conceptual matrix with all the inherent contradictions, aporias, and fault-lines that deconstruction has so ably helped us to see. Instead, we get a "more relaxed" view of theology and religion through the "sacredness" of language $(212,216)$.

Deconstruction has, in Sussman's estimation, remodeled the Abrahamic religions and in so doing created a redemptive space where all (religious) discourse can gather:

[D]econstruction establishes a community to the degree to which it renounces exclusion, violence, and, in the sphere of pronouncement and articulation, obtuseness and oversimplification ... [D]econstruction is the discursive venue offering the existing Western faiths whatever possibility they have of redeeming themselves. (180)

This repeats an articulation of the Enlightenment secular utopia, which has its own ontotheological infrastructure, a "venue" where "the patient explication of their maddening contradictions, paradoxes, and other anomalies" can, as Derrida would say, "take place," where it is possible to understand the irresolvable impossibility at the core of Western 
metaphysics (192). ${ }^{45}$ In the end, Sussman's reclamation of deconstruction is grounded in a literary faith, as expressed in his description near the end of his catechistic final section of deconstructive prayer:

[A]n affirmation of the linguistic facilities and processes making human cultural and interaction thoughtful; a declaration of the commitment to make thinking, deliberation, and the nonviolent conventions of interpretive and cultural reprogramming $[! !]$ the basis for any action ... and, a celebration of the diversity and otherness ... (239)

Thus, literary and poetic practice becomes "the endeavor of illuminating the world with language" (240) —a textualization of deconstructive religiosity similar to Taylor. Sussman also wishes to identify in the alignment of these faiths in the comparative religious framework the "coherence underlying and connecting the seemingly most divergent tracks of ideology, tradition, and communal identity" (241). Indeed, deconstruction is remarkably amenable, hospitable even, to such attempts to "break out" from its reputation for negativity or cynicism.

Sussman's detailed reading points to the difficulties of using deconstruction as a mode of analyzing religious texts and concepts, of "religious criticism," due to its very identity as such. It may be that deconstruction blocks theological thinking as Derrida claims, but it also produces such thinking, as Sussman, Taylor, and others consistently demonstrate, thus making it very difficult to facilitate a "turning back," so to speak, on theology as a mode of concept-producing discourse itself. Sussman identifies this limitation directly:

45 Sussman also points the way from Derrida to Žižek by highlighting the "madness" that Derrida ascribes to deconstruction's critique of Western culture: "deconstruction is an expression of madness, or madness's symptom or victim" (191). Ascribing the idea of "symptom" to a particular kernal of permanent antagonism in western ontotheology could be considered a wormhole between the theories of Derrida and Žižek and between deconstructive and psychoanalytic theories in general. 
[D]econstruction opens an abyss or shrine where another Western "variety of religious experience" takes place. Deconstruction's sustained engagement with Judaism/Christianity/Islam is too intense and complex for this encounter to be reducible to philosophy or to criticism, that is, to be a neutral or purely secular commentary issuing from the singularity-free or sanitized sphere. (195)

Without claiming such a "sanitized sphere" for this study, one can see the limitations of a putatively "deconstructive reading" (if such a thing is possible, or even impossible) of Western metaphysical concepts such as the use of covenant in a particular period (and location) of Reformed Protestantism. Such "criticism" as this study owns itself to be would need a theoretical resource not claiming so much religious resonance.

But even more so, the very historicity of covenant, to the very point of its disappearance as an operative theological term, carries with it a meaning that may perhaps be elided through a deconstructive treatment. As I outlined in the above introduction, "covenant" etymologically carries forward with it the legal resources of both pre-biblical treaties and English Common Law, and the act of "cutting" a covenant double-binds it to the re-legio of religion. However, even more importantly, covenant was used as a political tool at an historically important period of American history when developing certain concepts of polity. Covenant, in many ways, can be seen as a fundamental split at the beginning of what might be called "American political psychometaphysics."

\section{Žižek's Materialist Theology}

Žižek claims that Derridean deconstruction and Lacanian psychoanalysis are "two 
radically different global perceptions," and thus "all attempts to mediate between them ultimately fall short" (Žižek \& Hanlon 13). Glyn Daly locates the difference between deconstructive/poststructuralist and Lacanian theoretical positions as a contrast between the decentered, plural, and contextual emphases of the former versus the universal and transcendental claims of the latter. Nevertheless, Daly also sees great potential for "cross-fertilization" (75-6).

Indeed, Žižek has practiced a long-standing engagement with Derrida and deconstruction on both religious and political grounds. In his most sustained critique of both deconstructive "post-secularity" and Derrida's "spirit of Marxism," Žižek accuses deconstruction of clearing the way for "a new post-deconstructive and undeconstructible form of spirituality" whose selfdescribed "radicalization" of Marxism is in fact "the renunciation of any actual radical political measures." The political "Event" itself is made impossible; democracy is always, and by definition, "to come"; if democracy in fact occurs, it is in effect totalitarian (Totalitarianism 15260). Žižek argues that Derrida and the deconstructive movement, by positing an undeconstructible ideal of justice to come or of community without exclusion, deconstructs its own concept of différance, better understood as an unjustifiable otherness or difference that is already here.

However, one can posit a possible alignment through Jean-Luc Nancy's principles for understanding Christianity from the deconstructive perspective:

1. The only Christianity that can be actual is one that contemplates the present possibility of its negation ...

2. The only thing that can be actual is an atheism that contemplates the reality of its Christian origins. (140) 
Žižek cites these principles approvingly in his latest work on Christianity (Žižek \& Milbank 287) and the two principles neatly match the "paradoxes" for understanding Christian morality with which Derrida begins "Faith and Knowledge" (50-1). ${ }^{46}$ Žižek, indeed, sees the "un-heard of materialist potential" in the concept of différance divorced from the messianicity in Derrida's later work:

Having written many pages in which I struggle with Derrida's work, now—when the Derridean fashion is fading away - it is perhaps the moment to honor his memory by pointing out the proximity of the topic of my work to what Derrida called différance, this neologism whose very notoriety obfuscates its unheard-of materialist potential ("Plea for a Return to Différance" 231).

What Žižek here proposes is a return to the "old" pre-messianic, pre-postsecular Derridean notion of différance as pure in-betweenness, a Hegelian "thoroughly immanent 'contradiction' that precedes any Otherness." Thus, Derrida's "specter of a promise" of Otherness can be simply dropped, leaving the fundamental rupture or gap of différance in place; in other words, Žižek locates the undeconstructible infinite messianic justice "to come" already inside the inbetweeness of différance (232). ${ }^{47}$

Žižek is perhaps most clear in distinguishing his views of religion from Derridean deconstruction in his response to Breger's attack on his "postmodern political theology" as being

46 Žižek cites "Faith and Knowledge" when discussing fundamentalism as a "formal status of belief" in "Postface: Better Dead than Red--Again!" (223).

47 In Indivisible Remainder, Žižek identifies "the abyss that forever separates the Real of an antagonism from Derrida's différance: différance points towards the constant and constitutive deferral of impossible self-identity, whereas in Lacan, what the movement of symbolic deferral-substitution forever fails to attain is not Identity but the Real of an antagonism" which Žižek exemplifies in "social life" as "the constitutive splitting of the "body politic'" (100-1). Marcus Pound helpfully compares Žižek's theology of abandonment to Derrida's negative theology as the difference between the diachronic and synchronic, formulating a contrast between the perpetual (imminent) "to come" aspect of Derrida's deconstructive messianic promise and the structural (immanent) ontological gap that Žižek seeks to reclaim in Derrida's original use of différance (93-6). 
inherently anti-humanist (which he accepts) and anti-Semitic (which he emphatically denies).

Žižek starts with one of his most clear definitions of the key concept for his view of Lacanian

Real:

The Real is thus not the prereflexive reality of our immediate immersion in our life-world but, precisely, that which gets lost, that which the subject has to renounce in order to become immersed in his/her lifeworld — and, consequently, that which then returns in the guise of spectral apparitions. ("Rhetorics" 99)

From this, he develops two versions of the Real, one religious/idealistic and the other atheistic/materialist:

Religion is the Real as the impossible Thing beyond phenomena, the Thing that "shines through" phenomena in sublime experiences; atheism is the Real as grimace of reality, as the gap, the inconsistency, of reality. (100)

This is held up in opposition to the "Derridean/Levinasian assertion of the kernel of religion as the belief in the impossible Real of a spectral Otherness that can leave its traces in our realitythe belief that this reality of ours is not the Ultimate Reality." Instead, Žižek claims (adopting the Derridean language of Caputo) that atheism should be defined more properly as "religion without religion,"

the assertion of the void of the Real deprived of any positive content, prior to any content, the assertion that any content is a semblance which fills in the void. "Religion without religion" is the place of religion deprived of its content, like Mallarme's — this is atheism's true formula - "nothing takes place but the place itself." Although this may sound similar to the Derridean/Levinasian "Messianic 
Otherness," it is its exact opposite: it is not "the inner messianic Truth of religion minus religion's external institutional apparatuses" but, rather, the form of religion deprived of its content, in contrast to the Derridean/Levinasian reference to a spectral Otherness, which does not offer the form, but the empty content of religion. Not only do both religion and atheism insist on the Void, on the fact that our reality is not ultimate and closed - the experience of this Void is the original materalist experience, and religion, unable to endure it, fills it in with religious content. (100-1, his emphasis)

I quote at length to show not only the importance Žižek places on the distinction between deconstruction and his own Lacan-tinged views on religion, but also the distinction he makes between religion (deconstruction) and materialism (Lacanian psychoanalysis) as a mode of content versus form. Žižek not only appropriates Derrida's différance and chora ("nothing takes place but the place itself") and Caputo's "religion without religion" but also lifts the theological form of religion itself - "the place of religion deprived of its content"—and turns it back on religion's anxiety to fill the materialist nothingness with religious fullness. This, one might say, is a distinction with a true différance. Žižek finishes by offering his "strictly materialist" reading of Christianity, in which Christ stands in for the Real as "the Thing itself," as "nothing but the rupture/gap that makes Christ not fully human," and thus an "almost imperceptible shift in perspective" allows Christ's sacrifice to morph into the "community of the Spirit" formed on the "atheist assertion of life that needs no sacrifice" $(101,103)$.

This, then, in a nutshell is Žižek's formulation of the inherent and immanent contradiction or antagonism that stands at the heart of his "materialist theology." Though best known for "his 
reconceptualization of the theory of ideology" by showing how, as Peter McLaren puts it, "ideology works paradoxically and becomes post-ideological the moment it exposes its own soiled undergarments" $(622,625)$, Žižek materialist theology has appeared as a new front on the postmodern theological scene, and in paradoxical counterpoint to deconstructive theology alongside a resurgent orthodoxy.

Žižek has long used Christian tropes in his analysis of ideology. Ideology for Žižek, as mentioned above, requires an externalized unconscious factor. In his first book translated into English, Žižek defines the "ideological" as "a social reality whose very existence implies the non-knowledge of its participants as to its essence." Thus, Christ's defense of humanity to God while on the cross, "they know not what they do" (the title of Žižek's second book) is for Žižek the birth of ideology at the very birth (through death) of Christianity - its first theoreticization, so to speak (Sublime Object 21). Žižek betrays a fascination with the status of God through Christ, which he repeatedly claims represents the literal "death of God." Even before dying, "God subjectivizes Himself" through participation in the symbolic human realm of willful assertion of freedom. Thus, one must not believe in the "Big Other" for theological reasons, even though one cannot help but do so-Christian theology simply doesn't work without an emphatically dead God, yet one that must still be believed in ("Big Other" par. 5). ${ }^{48}$

Žižek's interest in theology can be followed chronologically from his early focus on ideology to his most recent engagement with the Radical Orthodoxy movement. ${ }^{49}$ Michael

48 It is unsurprising that Žižek later expresses a deep appreciation for Altizer's Death of God theology (Žižek \& Milbank 260).

49 See Kotsko and Pound for in-depth treatments of Žižek's use of theology. Both are addressed to theologians and come from an apologetic perspective, yet they provide useful overviews of Žižek's philosophical heritage and critiques of his engagement with theological concepts. Their conclusions are, for the most part, predictable: Kotsko supports John Milbanks and other proponents of Radical Orthodoxy in claiming Žižek practices a "Hegelian death of God theology" (137), and Pound more interestingly (and, perhaps, more accurately) calls Žižek's "a bastard theology without a Father" (xiv). 
Moriarty, in the first critical examination of Žižek's use of religious motifs, tracks through Žižek's early works how an "analogical digression [religion] has become the substance of the argument" (125). In The Sublime Object of Ideology (1989), Žižek was able to strip a "theory of belief" which "has no intrinsic theological content" from Pascal—religious activity (ritual) creates religious belief, the external shapes the internal—in order to buttress Althusser's concept of Ideological State Apparatuses, while in his later work theological concepts such as predestination and grace become necessary precursors for his theory of the subject (Moriarty 128-9). Žižek on multiple occasions joins with Kierkegaard in claiming that Christianity is eminently modern, particularly in the challenges thrown up (and, in some ways, caught) by the concept of grace and its impact on human freedom. As mentioned above, Žižek joins Alain Badiou in emphasizing St. Paul's greatness in "creat[ing] the possibility of universal affirmation," and extends that greatness through Badiou's reinterpreted or theorized "materialism of grace" which emphasizes the possibility (and hope) of a "gratuitous" interpellation of anyone (and everyone) into the proletariat $(131,133)$. Marx's "commodity-form" analysis had a tremendous influence in all social sciences, including religion, in throwing a radical wrench into the unified notion of the "transcendental subject" (Sublime Object 16-17) as supporting scientific objectivism. Instead, such a notion, similar to Freud's unconscious, serves in place of such unities as the foundation of knowledge. The "sublime object," therefore, is the immaterial "material" of symbolic authority, the objectification or reification of desire into belief (18). Žižek's development on the Pascalian and Althusserian inversions of belief and action demonstrate that the latter determines the former at the unconscious level. In For They Know Not What They Do (1991), Žižek extends and particularizes his 
theorization of Christianity by joining Jameson in identifying Protestantism as a "vanishing mediator" between feudalism and capitalism. Through its very universalization of the sacred sphere, Protestantism ironically led to religion's devaluation and privatization; once the world became "Protestant" in structure, filled with atomized acquisitive individuals, it no longer required its "positive religious form." Similarly, Jacobinism, by universalizing its ideal of democratic equality, led the way directly to bourgeois individualism, which is similarly "the actuality of freedom, equality and brotherhood" in content if not in form. As we saw earlier in both Jameson's treatment of Weber and Žižek's of Derrida, content and form are here reversed, in that content is the structure that evacuates the "values" of the original form-Protestant Reformation doctrine of grace, or Jacobin equality:

The passage from feudalism to Protestantism is not of the same nature as the passage from Protestantism to bourgeois everyday life with its privatized religion. The first passage concerns "content" (under the guise of preserving the religious form or even its strengthening, the crucial shift - the assertion of the ascetic acquisitive stance in economic activity as the domain of manifestation of Grace — takes place), whereas the second passage is a purely formal act, a change of form (as soon as Protestantism is realized as the ascetic acquisitive stance, it can fall off as form). (185)

In other words, the content of the belief system, religious or political, is divorced from its form and provides a superstructural legacy. Our illusion, Žižek claims, is that while we scoff at both Protestantism and Jacobinism, we continue to participate in their vulgar content (acquisitiveness and violence) without their positive form; we are nothing but Jacobites and Protestants without 
Jacobin and Protestant form (183-5).

Žižek continues in Tarrying with the Negative (1993) to identify an ontological "gap" in reality through theological terms, namely the "Christian Sublime" as the "extreme discord" and "absolute gap" between divinity and the "monstrous distortion" of corporeality which "is the divine power of 'absolute negativity' ... the Christian God is this gap itself" (50-1). Žižek is then able to establish what he calls "the materialist notion of God" in positing God as the possibility of the One Who Knows, which is for Žižek an impossibility but a "necessary perspective illusion" for the formation of subjectivity through a "spiritual Substance" whose status is, of necessity, "virtual" (139). Žižek extrapolates this material-spiritual virtuality directly to the social realm:

An individual experiences his society not as a mere collection of individuals but as an order which transcends their individuals and forms the substance of their lives - and it is this very substantial in-itself which is purely virtual, a symbolic fiction, since it exists merely as the presupposition, by each of the individuals, of the already-existing co-ordination of all other individuals. ... In this precise sense, every human community is 'virtual': founded upon rules, values, and so on, whose validity is by definition presupposed, never conclusively proven - the status of the big Other is forever that of a semblance. (139-40, his emphasis)

God, therefore, is not just a socially necessary fiction but a necessary presupposition, a structural part of social relations - a political concept.

Grace, in turn, is identified as a by-product of the moment of the subject's release of 
autonomy, of giving up on grace, on God. It is co-equal with the "death of God" in that it is "the sign of equality between God and man" at the same time as it is a sign of their radical inequality: "[T]he intervention of Grace is not something distinct from the preceding loss, but is this very loss, the same act of self-renunciation, conceived from a different perspective" (170, his emphasis). Grace signifies, specifically, the conversion of God from Christ to the community of believers, the result of a complete "giving up" or "loss" of God proper (168-71). Later, in The Indivisible Remainder (1996), Žižek describes "subject," in relation to "grace," as not what is left behind once all is sacrificed, but the very act of giving up, what Žižek here calls "transubstantiation," which he sees as consubstantial with subjectivity itself: "[P]rior to this 'transubstantiation' the subject is not a subject at all, since 'subject' is ultimately the name for this very 'transubstantiation' of substance which, after its dissemination, 'returns to itself', but not as 'the same'"' (126, his emphasis). Developing Schelling's argument for God bestowing a conflictual freedom on man into a godless antagonism of subjectivity, Žižek reinterprets the theology of predestination to be a "free decision" in which the "subject predestines himself" into "free" existence through "an unconscious primordial act of decision" (18). This is a unique "theology" of grace, but one with roots in the same predestinarian logic of Reformed Protestantism.

In The Ticklish Subject (1999), Žižek continues using theological terminology to, as Terry Eagleton puts it, force the cultural-materialist academic world to once again face "the embarrassments of the unconscious" as the grounding of true material being and subjectivity (50). Žižek does so in part by closely identifying Heidegger's free assumption of one's destiny to "the theological problematic of predestination and Grace: a true decision/choice ... presupposes 
that I assume a passive attitude of 'letting myself be chosen'-in short, free choice and Grace are strictly equivalent; or, as Deleuze [and, as we shall see, Jonathan Edwards] put it, we really choose only when we are chosen" (18). Through this and other theoretical moves, Žižek is able to propose a "Materialist Theory of Grace" based on the Hegelian notion of a "concrete universality" which he defines as "the irreducible and ultimately unaccountable gap between a series and its excess, between the Whole and the One of its exception." The resulting "political logic of the excess constitutive of every establish order" he finds best exemplified by Carl Schmitt's theory of political theology, based on the constitutive sovereign exemption to the rule of law - basically, he who makes the rules can break them — which, in turn, resides on a foundational violent act that grounds the law in itself..$^{50}$ This paradox or double nature of law is most evident in religion, and Christianity in particular, where Christ fulfills the Law by directly undermining it. Thus, following Kierkegaard, Žižek finds that "religion is eminently modern" and, more specific to Protestantism, "the properly modern God is the God of predestination" who rules through the "abyssal act of decision" understood through the "sign" of one's good (or bad) deeds (113-15). As such, Christianity became a successful ideology because it was able to make its internal contradiction — solidarity with the oppressed simultaneous with maintenance of existing power relations - cohere through theological mechanisms that appear to Žižek (and his compatriot Badiou) precisely aligned with modern theory (186). Taken to the political dimension, "antagonism is inherent to universality itself" in that the impossible call for true

50 For Žižek's more comprehensive engagement with Schmitt, written during the same period, see "Carl Schmitt in the Age of Post-Politics." Schmitt demonstrates that an "irrational" sovereign God is the necessary basis for a "rational" political theology, but in the end "the theological background to Schmitt's assertion of political antagonism" does not extend to an "adequate theoretical articulation of the logic of political antagonism," leading to Schmitt's "rightist political orientation" (27). In short, Schmitt's theological formulation of fundamental antagonism is correct but inadequately applied to politics. Žižek instead recommends "the return of the political proper, that is, the reassertion of the dimension of antagonism which, far from denying universality, is cosubstantial with it" (35). 
universality, what Žižek identifies with Balibar's egaliberte (equality-liberty)—very similar to Derrida's "democracy to come"—-must constantly stand in a state of opposition to the existing system of "concrete universality" that denies true universality (223-4).

The Fragile Absolute, or, Why Is the Christian Legacy Worth Fighting For? (2000) represents Žižek's first sustained, book-length engagement with Christian theology, an attempt to reclaim a non-obscurant Christian legacy for Marxism. In it, as Cannon summarizes, "the Lacanian notion of la travers[e]e du fantasme [traverse the fantasy] meets the Christian notion of the Divine Act of Grace" in that the subject (pre)destines history through one's actions; one becomes saved through acting as if one were saved. Theology, as it were, fits into what Daniel Dennett calls the "bizarre category of the objectively subjective" and which Žižek translates as "fantasy": "the way things actually, objectively seem to you even if they don't seem that way to you"(83); one "believes" in a theology even if one doesn't think one does. What's more, this fantasy is not a distraction from truth but the very "monstrous ... violent singular excess" which provides a basis for one's essential truth, the ground for one's "cosmic order." Thus, "metaphysics"—-theological, political, psychoanalytic, or otherwise—must "admit that our distortion of truth is grounded in an inherent distortion constitutive of the truth itself" (86). Where the subjective personal fantasies of individuals reaches the collective and historical level is through our status as "historical agents" who are "the materialization of the ghosts of past generations, as the stage in which these past generations retroactively resolve their deadlocks" (90-1). Our present is literally haunted by the ghosts of past theories and theologies that projected forward, both in potential and in practice, the hopes and dreams of our forebears. The past is thus open not just to understanding what happened but also what was meant to happen, 
what subjunctive potentials were crushed and not allowed to take place. Finally, taking from Lacan's Seminar XX: Encore "the logic of 'non-all' and of the exception constitutive of the universal," Žižek points to the direct coincidence of any universal series and a series of exceptions, resulting in a universal series of exceptions $(115-6) .^{51}$

Unfortunately, at the end of Fragile Absolute Žižek too quickly attempts to quilt all these Christian paradoxes into a Pauline agape love-fest. His next book, On Belief (2001), is a much more granular and critical appropriation of Protestant theology. Žižek's gambit in On Belief is to develop a materialist version of uncompromising Christianity, exemplified by a Southern Baptist on Larry King stating that "a lot of good and honest people are going to burn in hell" (1). ${ }^{52}$ Christianity accomplishes a "shift from external to inherent limitation" (89) through Christ's human divinity which performs an impossible equality between God and man; the split between the divine and the human is intrinsic to the human; in other words, we all share in an inherent inequality to/in ourselves. Christ is not "'man PLUS God"' but "the divine dimension in man 'as such"' (90). Žižek follows the Gnostic "heresy" of taking Christian theology seriously: Christ condemns man to never fully becoming man, but instead must incorporate as the Holy Ghost into a community of believers which, structurally, makes an afterlife a theological impossibility (91). Thus, Christianity highlights a radical, internal and pathological inequality in the very nature of humanity that we all equally share. Christ, for Žižek, "directly embodies/assumes the excess that makes the human animal a proper human being," which is itself an embodiment of "Lacan's paradoxical logic of Non-All: every totalization has to rely on an empty Master-Signifier which

51 One could call this the paradox of American equality: we are equal as exceptions, as inequal and unique individuals. We are equal only in our inequality to each other.

52 The first endnote states that the book "prolongs, often in a self-critical mood, the analyses of my The Fragile Absolute"; the statement, and the quick rapid release of a new book on the same topic, demonstrate an uneasiness with his initial full-born theoretical foray into theology. 
marks its constitutive exception" $(99,101)$. Translated back into Christian theo-dynamics, the totalized equality of "being human" can be referenced to Christ's non-identity with His own divine status. Christ's own constitution, one could say Christ's inherent covenant, shows the radically negative path toward being a truly exceptional people. Žižek expands on this nonidentity of Christ in the final volume of his Christian triptych, The Puppet and the Dwarf: The Perverse Core of Christianity (2003), where he makes the surprising claim that "Christianity, precisely because of the Trinity, is the only true monotheism" in representing the true constitutive gap "which simultaneously separates God and God and man and man" (24).

By the time Žižek reaches the chapter "Building Blocks for a Materialist Theology" in his self-described magnum opus, The Parallax View (2006), the blocks are already discernible as a theoretical structure. He describes his "return" to dialectical materialism as a Möbius strip reinscription of the Christian gap in meaning, which is "reduced to the minimal difference between the presence and absence of meaning itself ... the only 'content' of pure Meaning is its form itself as opposed to non-Meaning" (85). Thus, re-inscribed onto the human subject of this formal "short circuit" between the presence and absence of meaning, the subject finds itself "as the excessive core of inhuman monstrosity at the very heart of the human being" (102). It is not a long leap to the Monstrosity of Christ (2009), Žižek's latest exposition of his antagonistic theory of Christian meaning - Christ as the simultaneous death of God and birth of the human subjectwhich he posits in counterpoint to the respectable theistic forces of Radical Orthodoxy's main proponent, John Milbank.

From the beginning with Sublime Object, Žižek's theoretical arc has been to fully explicate Hegel's "infinite judgment"_-a judgment in which subject and predicate are radically 
incompatible, incomparable: 'the Spirit is a bone', Wealth is the Self', 'the State is Monarch', 'God is Christ"' (207)—as the impossible connections or "short circuits" between incompatible modes of meaning through which truly ethical potential events may occur. My argument is that "Grace is Works" belongs in this list of incompatible, incomparable terms that nonetheless point to the sublime object that is an early American theology with long-standing, far-reaching political implications. I will use Žižek's theory of theology to explain not only the theoretical dimensions of covenant theology in early America but how these dimensions underlie the "symbolic tradition" of American politics:

One becomes a full member of a community not simply by identifying with its explicit symbolic tradition, but when one also assumes the spectral dimension that sustains this tradition: the undead ghosts that haunt the living, the secret history of traumatic fantasies transmitted 'between the lines', through its lacks and distortions. (Fragile Absolute 64)

It is my contention that the theology of the covenant is one such "ghost" that continues to haunt the American communal discourse at its highest and lowest levels—as a traumatic fantasy of transcendent political fulfillment through an illusion of personal freedom.

Politically, Žižek ends Sublime Object by connecting his theory of subjectivity to the Protestant vision of predestination. "For freedom to take place (as our positing)," he claims, "it must already have taken place in God as his incarnation" (230). God, by positing freedom, prepositions subjective humanity to posit freedom - an external "reflexive determination" of Godlike power. In other words, to be free a subject must presuppose a God, a "big Other." And this freedom, Žižek suggests, by resolving the antagonism of subjectivity, is the worst case of 
servitude. 


\section{CHAPTER 2: THE COVENANT IS REFORMED}

Scripture knows nothing of the names: Covenant of Redemption,

Covenant of Works, and Covenant of Grace.

Charles F. Lincoln, "Biblical Covenants" 309.

[T] he recognition of unresolved logical tensions in theology is a distinctive mark of Calvinism.

Anthony A. Hoekema, "Covenant of Grace in Calvin's Teaching," 135.

The mentors of the puritan psyche knew well that nothing

distressed —or should distress—-their charges more grievously than

the right deed done for the wrong reason.

Michael McGiffert, "Grace and Works" 468.

All contention comes from holinesse.

Thomas Hooker, The Paterne of Perfection, 223.

Scholarship on the trajectory of the covenant concept in Reformed Protestant theology is as rich as it is obscure. Nearly every aspect and phase of its usage, from its birth in the mind of Zwingli in the early 1500 s to the current debates in Presbyterian devotion and theology, has been widely studied and explicated. ${ }^{53}$ However, as mainstream theological topics go, the covenant

53 For the best reviews of the literature on the topic, see Bullinger, Hall, von Rohr, and Greaves. 
does not draw much general interest, and specialized attention vacillates depending on current trends in scholarship. Perry Miller's emphasis in the 1930s through 50s on the role of covenant theology to morph Calvinism into New England's practical theology developed a gold rush of scholarship and dissertations into the "New England Mind" that has since been met with an equal reaction of disinterest and dismay. One could say, with accuracy if not generosity, that field of early American religious and cultural studies regards covenant theology (to continue the metaphor) either as a mine now emptied of precious materials or one that only produced fool's gold.

Miller inspired numerous historians of religion, most notably Michael McGiffert, David A. Weir, John von Rohr, and E. Brooks Holifield, to develop a rich scholarship on the sources and impacts of the Puritan covenantal tradition. Their focus up to the present has been on intellectual and theological history, and the knowledge developed has been applied to other disciplines, notably literary studies. However, a critical theoretical approach to the covenant concept as employed in early American literature has not, to my knowledge, been performed. Instead, this quasi-theological term in the Reformed tradition, tangential to more central concepts of predestination and original sin, continues to be a source of confusion, dismissal, disdain, and begrudging interest in the study of the New England Puritans.

One concern many religious historians have with the concept of the covenant is its inherently political nature, which draws controversy. Dewey Wallace, in his 1982 study of grace in Puritan theology, explains in an appendix that he "by and large avoided discussion of the theology of the covenant" because "so much has already been written about it ... partly because it seems to have so many social and political ramifications" (197). McGiffert in the 1990s notes a 
"change in emphasis" in Puritan studies shifting from unresolved to resolved tensions, "more, now, on assurance than on anxiety, more on the resolution than on the problem" (Shepard, God's Plot xii). ${ }^{54}$ This new emphasis on what his peer David Hall called the "coherence of American Puritan studies" focuses on the goal of seventeenth-century covenant theologians which, as William Stoever maintains, was not "the straining paradox that modern interpreters have occasionally found it" (110). Instead, covenant theology, and the covenant of grace in particular, "was intended to clarify and underwrite the terms of assurance for true believers" (Shepard, God's Plot 12). ${ }^{55}$ Similarly, as Hall emphasizes, Puritan historians "are less concerned ... with tracing the consequences of a single ruling idea such as Miller's 'covenant'" than with a more comprehensive view of the Puritan movement. Thus, literary scholarship moved away from the covenant as an organizing concept and instead incited "a veritable revolution in our understanding of the Puritan 'imagination'" abetted by the exegetical norms of typology (Hall 195 passim).${ }^{56}$ Hall maps a renaissance of Puritan scholarship that marks a "recovery of a

54 This can be noted in the shifts in subtitles from the first (1972) to the second (1994) versions of his edited book: God's Plot: The Paradoxes of Puritan Piety to God's Plot: Puritan Spirituality in Thomas Shepard's Cambridge.

55 Simply, McGiffert goes on, the covenant of grace "declared that salvation did not depend on the good behavior or character of the saved sinner, and it guaranteed that God would sustain those whom He had chosen."

56 The history of what Hall calls "the symbiosis of literary method and the practice of piety" ("On Common Ground" 222) in Puritan literary and religious historical scholarship should include a serious investigation into what Thomas Holbrook calls the "American habit of typology" in its literary criticism. For example, Philip Gould re-inserts Puritan typological method back into understandings of nineteenth historical fiction: "Puritanism is much less a stable analogue than a protean metaphor for the early republic" (8). Similarly, Ellen Spolsky uses the conditional aspect of the covenantal concept as a hermeneutic for reading American literature from out of a particular theological (Jewish) tradition: "Covenantal hermeneutics challenges us to admit that ... holding an ideology ... means having to make choices, and having to own up to them" (xv). A full identification between literature and religion or theology is best exemplified by Amy Hungerford's analysis of "literary beliefs" in late-20th century fiction, which she argues should be considered "species of religious thought" which provides an avenue to bring together transcendent meaning and diverse indeterminacy within a constructive literary practice (xvi, xxi). One can sense this approach in studies showing a direct relationship between Reformed Protestantism and American literature, such as Barnstone, Manson, and Singley's edited collection of essays on the Calvinist influence on modern American literature; or Patricia Caldwell's identification in Puritan conversion narratives, like the relations documented by Thomas Shepard (discussed below), the introduction of a particular mood or feeling as one possible beginning for American literature. This approach is anathematic to the present study. 
tradition of discourse." This discourse, however, by setting Puritan contradictions and tensions against one another, makes inconsequential the actual theological and political issues at stake for the Puritans, as well as for the historians. These staid "tensions," couched within emotive or general terms of "anxiety," "piety" (used and rejected by Miller's Puritans), and "conviction," do not take into account Puritan eschatology and their own attempts to define within terms such as "covenant" a pure and thus certain relationship with God. The covenant, by linking temporal "moods" in a legally-bound divine agreement, is a much more difficult term to apply to real people, since it incorporates and sets into motion historically the tensions normally attributed to mere "emotion." Hall's "confidence of language" in modern criticism is in fact a re-creation of the crisis of language that the Puritan writers themselves went through three centuries ago. Nevertheless, for theologians who seek to both explicate and espouse Reformed Protestantism, covenant is still central: "Explicitly or implicitly, the doctrine of the covenants provides the organizational structure for the entire Reformed theological system" (Karlberg 12). ${ }^{57}$

While we will make full use of the extensive scholarship on covenant theology as it was developed in the Reformed tradition, our purpose will not be to attempt a reconstruction of the "coherent" theological edifice created by the New England Puritans and their theological forebears. Such coherence is reflected more in the scholarship than in the conceptual matrix of covenant theology — or rather, the ability of covenant theology to utilize the resource of the covenant concept to create a false coherence mirrored by the practitioners and historians of covenant theology. Rather, we will seek to theorize the concept of the covenant in early American writings, which will require a more literary reading of theological texts and contexts.

57 In The Liberating Bond, Roth, Ruether, and McWhorter introduce and centralize the concept of the covenant for contemporary liberal American Christianity, providing an amenable narrative of the "history of covenantal relationship to God in Judaism, in the Christian Church, and in American history" (84); the book comes with a user guide, is published by the National Council of Churches, and appears to be non-denominational. 
In so doing, we will find that the covenant concept provides a much less stable foundation for a theology of certainty than the current scholarship maintains, enacting instead its own negation as a political framework for salvation.

\section{History of the Reformed Covenant - Grace and Works}

It is fitting that the identification of the covenant as a major component of Reformed Protestant theology came out of Miller's interests in American intellectual and literary history as a source for American political meaning. ${ }^{58}$ Launched by his thesis first presented in "The Marrow of Puritan Divinity" (1935) and expanded on in The New England Mind: The Seventeenth Century (1939 — referred herein as NEM:SC), the concept of the covenant provided an important political as well as theological foundation for the social architecture of Puritan New England.

Scholars then traced this concept back through the founding sixteenth-century Reformed

Protestant theologians in continental Europe.

Even his harshest critics acknowledge that Miller's focus on covenant theology sparked widespread theological interest in the subject (Bierma, "Federal Theology" 304). Ever since, Miller has been consistently and effectively critiqued for his portrayal of the New England Puritans' beliefs, in particular his "basic distortion of one of the most crucial of Puritan concerns, their doctrine of the covenant" (Marsden 93). He stands accused for creating a drama where the New England Puritans slyly inserted moral law and human responsibility back into the

58 Although it could be argued that Miller's main influence was in American intellectual and religious history, he taught literature at Harvard for most of his career and interacted most directly with other great shapers of the American literary tradition, including F. O. Mathiessen. Miller's interest in early American religious history has its own political and economic (and, perhaps, mythological) beginnings in the Congo, where he found himself unloading oil drums as a rebellious teenager who withdrew after his first year in university. He describes having an "epiphany" that "thrust upon me the mission of expounding what I took to be the innermost propulsion of the United States" (Errand vii-viii). 
predestinarian scheme of authoritarian diktat, creating a transactional arrangement between God's sovereign power and humanity's ability to secure the conditions of its own salvation. ${ }^{59}$ Miller's greatest myth was that "the covenant of grace represented a revision of Calvinism" (105), a revision that could not be helped, shown most starkly in the awkward "Halfway Covenant" creation that kept late-seventeenth-century New England church polity limping along. In one of his earliest works demonstrating typical intellectual bravado, Miller identifies the problem in the administrative powers of the covenant itself:

Yet I can not altogether sympathize with the church historians who have unanimously condemned the synod for having guided Congregationalism into compromise and legalism. The leaders of the day faced their task manfully and intelligently, they brought to bear upon it all the learning and insight of their generation. The fault, if it can be called a fault, lay not in themselves but in their stars. They were committed by their inheritance and their characters to the wellnigh hopeless task of bolstering up a system founded on the courageous but illconsidered conviction that the wayward, subjective mysteries of regeneration could be institutionalized in an ecclesiastical system. (Miller, "Half-Way Covenant" 714)

No matter how "manfully" the New England clergy worked at instituting the theological system of the covenant, it would not fulfill the structural, cultural, and institutional requirements of the age.

The reason for this failure or lack in the covenant doctrine is a mystery that Miller never

59 One could claim that this is a drama whose source is more Weberian than Zwinglian: "Many historians, particularly since Max Weber, have regarded this covenant doctrine as an harbinger of modern ideas of man, society, and law" (Witte 600). 
completely works out. Covenant, or "federal" theology as it is often called, proved to be both a difficult and essential concept for its practitioners as well as for those who study its history. While Miller propelled federal theology into mainstream Puritan studies, he later said concerning the reception of his work, "the modern mind has so little appreciation for such nuances as the federal theology contains," even though federal theology provided the very "constellation of ideas basic to any comprehension of the American mind." Federal theology was "simply an idiom in which these Protestants sought to make a bit more plausible the mysteries of the Protestant creed. That the idiom many times took such mastery over the creed as in effect to pervert it is one of the ironic dramas of the human intellect" (Miller, Errand 49). It never occurred to Miller that the perversion may be inherent in the creed itself, making the Puritan use of the covenant motif less ironic than indicative. ${ }^{60}$

Much of the debate surrounding covenant theology and Miller's identification of its primacy has to do with its relationship to the founding strands of Reformed Protestantism. Miller sounded the gunshot of a long-standing debate regarding the relationship of the New England Puritan's theology to Calvinism by claiming that "[federal theologians'] imposition of the covenant doctrine upon the system of Calvin produced at last in the New England theology an altogether different philosophy from any propounded in Geneva" (Miller, NEM:SC 367). ${ }^{61}$ Miller's understanding of the covenant was heavy on conditionality, which he saw as pretty much the entire point of this theological innovation: "[God] made both the Covenants 'conditional', that of grace no less than that of works, so that they would be relations founded upon mutual

\footnotetext{
${ }^{60}$ In NEM:SC, Miller categorizes his most extended discussion of covenant theology under the section "Sociology," pointing to his understanding of the political and sociological direction of the covenant's "perversion."

${ }^{61}$ For an excellent review of literature to date on covenant theology, see von Rohr, Covenant of Grace 17-30.
} 
stipulations, not upon brute fact" (383) ${ }^{62}$ Many historians, seeking to reclaim American intellectual history from the strictures of Calvinism, excitedly fleshed out this thesis, laying the pathway all the way back to the founders of continental and English Protestantism to identify an alternative Reformed tradition based on a less predestinarian, more conditional, bilateral covenant:

There are thus two distinct streams of thought which contributed to the development of covenant theology in England: (1) that of Zwingli, Bullinger, and Tyndale, emphasizing the nature of the covenant as an agreement, and the responsibility incumbent on man as the result of the more or less legalistic vows taken in baptism; and (2) that of Calvin, emphasizing the promissory nature of the covenant as given by God, and the distinction between law and grace in a covenant context. ${ }^{63}$ (Greaves, "Origins" 32)

According to this theory, first proposed by Leonard Trinterud in his 1951 essay "The Origins of Puritanism," covenant theology provided the "intellectual formulation" for an Anglicized version of the first Protestant tradition coming out of the Rhineland, and that this "law-covenant principle" provides the linchpin that connects "older English piety, practice and preaching" to the development of "state contract theory" (41, 50; see also Bierma, "Federal Theology" 304). ${ }^{64}$ Most recently, the theory of dual traditions has been propounded by J. Wayne Baker, focusing on the

62 While the condition for the covenant of works is obedience to the law, the condition for the covenant of grace is faith, but of a particular kind, as "covenant-faith has in the law a way prescribed for it to walk in" (385).

63 Some trace the alternative conditional covenantal tradition all the way back to "Melanchthon's doctrinal shift from absolute divine sovereignty to cooperative human agency in individual salvation" (Bierma, "Role" 454). Lincoln sees no evidence of covenant theory in Luther, Zwingli, Calvin, or Melanchthon, who "built up their complete systems apart from any such theory" ("Development" 149).

64 This is especially true, he found, of certain Separatist churches: "Some of these radical Separatist groups rejected all ideas of predestination, and carried their church covenant to the extent of receiving theologically nothing beyond that which was accepted by the mutual agreement of the brethren" (Trinterud 49). 
influence of Bullinger on the development of an alternate federal tradition predating Calvin that "did not attempt to solve the tensions ... between conditional covenant and sola gratia" but instead presaged the New England Puritans in applying covenant thought to social and political practice:

And it was the New England Puritans who, like Bullinger, made the covenant the basis for Christian society. The social covenant was based on the religious covenant; political society thus existed within the framework of the covenant. ${ }^{65}$ (Baker, Heinrich Bullinger xxii - xxiii, 166)

This idea of a dualistic split in the Reformed tradition, let alone the idea of the New England colonists being more Bullingerians than Calvinists, has been justifiably called into question as being overly simplistic and dualistic, and accused of reading a more robust covenant theological structure found in later Reformed theology back into their forebears' thoughts (McGiffert, "Grace and Works" 500n92; Bierma, "Federal Theology"; Lincoln, "Development" 136-7). Lyle Bierma, in particular, does not understand why scholars find tensions between the sola gratia unconditional covenant and bilateral mutual covenant in some early Reformers and not others, as "precisely the same tension is present in Calvin, and in all of early Reformed theology for that matter," when they developed their coherent soteriologies (systems of salvation):

What scholars from Trinterud to Baker have failed to realize is that all the sixteenth-century Reformed covenant theologians—Zwingli, Bullinger, Calvin,

${ }_{65}$ See also Baker's defense of his thesis in "Heinrich Bullinger." Baker's emphasis of the "federal" (i.e., conditional) nature of covenant theology is colored by his later attempt as a co-author of Fountainhead of Federalism (McCoy and Baker) to attach federal theology to a broader political "federal tradition," which republishes Bullinger's One and Eternal Testament or Covenant of God (1534) following a penultimate chapter on "Federalism and the U.S. Constitution of 1787." Like most historians of the covenant (myself included), Baker's purpose is broader than historical theology; nevertheless, directly connecting a particular Protestant theology with an American political "doctrine" is ideologically loaded and thus should be treated carefully. 
Olevianus, Musculus, Ursinus, Perkins, etc.- - recognized both a unilateral and a bilateral dimension to the covenant of grace within the context of a monergistic soteriology. The tension that Baker found in Bullinger's theology between salvation by grace alone and a conditional or bilateral covenant of grace is present throughout early Reformed soteriology. (Bierma, "Federal Theology" 315-6, 321)

Bercovich agrees, finding that though the covenants are "sharply divided ... the Puritans managed to circumvent tradition" by seeing themselves "as a chosen people under a covenant that was at once provisional and absolute" (33). Without recreating in full the controversies surrounding the proper understanding of the covenant in Reformed theology, we can see the concept used in an attempt to stabilize internally incoherent divine attributes within the Reformed theological system, while at the same time experiencing difficulties and "tension"-in the sixteenth, seventeenth, and twentieth centuries - explaining their own theology to themselves. What none of the investigators of early covenantal literature seem to acknowledge is an internal inconsistency and instability inherent in the covenant concept itself that cannot help but show itself in theological explication and political activity.

Some details of this controversy, along with its background in historical Reformed Protestant thought, are required to flesh out aspects of covenant theology's use of the covenant concept. The Reformed Protestant theology of the sixteenth and seventeenth centuries, according to Miller, is a "system of thought [that] rests, in the final analysis, upon something that cannot really be systematized at all, upon an unchained force, an incalculable essence"—grace (Errand 52). The covenant, by providing a mechanism for systematizing the unsystematizable, became for the New England Puritans "the foundation for the whole history and structure of Christian 
theology ... the scaffolding and the framework for the whole edifice of theology ... the essence of the program of salvation" (60). As such, the covenant functioned as an accommodation for an untenable religious (and ultimately political) philosophy, a product not just of "theology and revelation, but from law, from the study of nature, from the principles of a reason and common sense" (97). Most scholars as well as proponents of Reformed theology agree with Miller in seeing the primacy given to the covenant to be the "genius" of Reformed thought, in being able to resolve the tension between law and gospel still existent in Lutheranism and other iterations of Calvinism (Trinterud 55; Kline 13). von Rohr summarizes the consensus that the covenant idea "was frequently drawn upon in presenting to anguished spirits adequate grounds for confidence of salvation," providing a "comfort found in the very nature of covenant itself," in its contractual construction binding God to fulfill His promises, thus functioning as a well-laid and dependable "avenue of grace" ("Covenant and Assurance" 195-8). What's more, the covenant provided a resolution to the "basic antinomy ... of divine sovereignty and human freedom," providing for "their dual presence in this Puritan thought" (Covenant of Grace 1-2, 33). However, the impact of the covenant on the "incalculable essence" of grace, while less under-handed than in Miller's estimation, is still considerable. Meredith Kline, as a modern confessional proponent of covenant theology, goes so far as to fully subordinate grace under the rubric of a covenantal legal framework: "Coherence can be achieved in covenant theology only by the subordination of grace to law" (35).

Diverse and conflicting reasons are proposed for the appearance of this "genius" in Reformed Protestantism. Stephen Strehle claims that the covenant theologians of the seventeenth century were significantly influenced by late-Medieval scholastic tradition, to the point that "one 
could justifiably denigrate these Calvinists as Neo- or Protestant Nominalists" (3). ${ }^{66}$ John Witte

points to the importance of the series of Bible translations into English, from Tyndale (c. 1532)

to the Geneva Bible (1560), which translated the Hebrew berith and the Greek diatheke as

"covenant" (583n10). ${ }^{67}$ Arguing for more contextual then textual roots, Christopher Hill points

out that covenant theology developed in parallel and probably was influenced by (and was an

influence on) the growing reliance on contracts in seventeenth-century commerce (4), and David

Zaret goes so far as to claim that covenant theology, much like English Protestantism during the

reign of Henry VIII, arose out of political and institutional contingency rather than theological

contemplation (5) ${ }^{68}$ Ellen Christiansen offers a more comprehensive view of the biblical

covenant which, by combining secular and religious traditions, "is never a purely religious,

vertical relationship, but it always has a social dimension," in the end becoming a theoretical

concept tied not to ethnic identity but to one's perceived soteriological status as one of the Elect

(7-8, 324). Regardless, Reformed Protestantism's dubious success in using the covenant to

reconcile and elide theological conflicts demands a theological explanation.

We now turn to the elements and construction of the theology now known as "covenant

theology," though to most Reformed Protestants from the sixteenth through eighteenth centuries,

the various covenants were simply part of an overarching theological edifice. Covenant theology

66 This same argument is made by Heiko Augustinus Oberma; McGiffert finds only a superficial resemblance and finds little evidence to confirm the linkage between Catholic Medieval Nominalism and Reformed covenant theology (McGiffert, "Grace and Works" 493n70).

67 The influence of these biblical translations are discussed at length in the above introduction.

68 Zaret in particular brings a unique theoretical approach, utilizing sociological organization rather than literary critical theory to prove that organizational pressures are no less important than intellectual precedents for understanding the origins and development of Puritan covenant theology. However, Zaret (along with Miller and even Žižek at his weakest moments) clearly identifies with the Weberian reductionism of Reformed Protestant theology to sociological terms, going so far as to claim that an appropriate sociological approach to covenant theology solves Weber's problem of certainty of salvation, which "provides the link Weber sought between religion and capitalism" through its "more palatable version of Calvinism" (10). Covenant theology, therefore, reflects a core economic doctrine of "possessive individualism," making it one in a number of streams within the wider flow of the philosophical and economic ideology of classical liberalism (18). 
sets out in its full development in the seventeenth-century Reformed tradition a theological principle of a prehistorical covenant between the Father and Son figures of the Godhead for enacting the conditions of salvation (incarnation, crucifixion, resurrection) called the "covenant of redemption." This overarching covenant was first expressed through the "covenant of works" between Adam and God which required obedience to the moral law for salvation from eternal damnation. When Adam, as the representative of the human race (hence "federal"), broke that requirement, God allowed the law to be fulfilled instead through the "covenant of grace" whereby the Son (Jesus Christ, the "Second Adam") fulfills the requirement of death through the crucifixion and a select number of humans (the "Elect" or "Saints") who have faith in this sacrifice are saved. However, as Charles Lincoln points out in the epigraph for this chapter, none of the above covenants — of redemption, works, or grace — actually appear in the Bible, and their history of development in the writings of Protestant theologians are open to interpretation. ${ }^{69}$ Instead, covenant theology retains its status as a biblically derived theology by relying on the overarching covenantal structure of the Bible that expresses itself through the individual covenantal roles and responsibilities. John Ball, in his Treatise of the Covenant of Grace (1641), provides one of the best early defenses for the ambiguous usage of the term:

The Covenant is one thing, the name of the Covenant is another. For the Covenant includes the whole reason of the Covenant with the circumstances: but the name sometimes is attributed to some circumstances. So the Covenant may be said to be

${ }^{69}$ For a more detailed summary of the covenant theology, with the different covenants defined, see Lincoln, "Development" (134-5).Robert Whittemore claims the source of the tripartite covenantal structure is in New England minister Samuel Willard's posthumous publication Compleat Body of Divinity (1726), which cites three distinct divine covenants: the "Covenant of Redemption" (pre-historical), the "covenant of works" (first day of creation), and the "covenant of grace" (made both "eternally and contemporaneously") (422-7). Samuel Rutherford, in The Covenant of Life Opened (1654), further distinguishes in the intra-Trinitarian and extratemporal Covenant of Redemption a "Covenant of Designation" made by God with Christ "in pre-history" and a "Covenant of Actual Redemption" which is "its historical redemptive enactment" (Covenant of Grace 44-5). 
the same and not the same, that which is the same in substance, varieth in manner and circumstances. $(5)^{70}$

The concept of covenant in the seventeenth century as "an agreement between two parties based on the fulfillment of certain conditions" was widespread (Greaves, "John Bunyan" 153). ${ }^{71}$ However, the "problem of the covenant in Puritan thought," as McGiffert and others have found, is that, though a major theological conception in Puritan theology, "the idea [of the covenant] was not a clear and simple one, but susceptible of various, inconsistent, even contradictory glosses" ("Problem" 115). McGiffert, in his thorough study of the sources for Peter Bulkeley's Gospel-Covenant (1646), stresses the difference scholars have found between the Puritan conception of a covenant and our modern conception of a contract:

Contract assumes the ability of the contracting parties to make and keep agreements; covenant presupposes a relationship in which all ability lies on one side, none on the other. Contractual relations are defined as voluntary and limited on both sides; covenant implies an involuntary and unlimited response by the inferior party to the wholly effectual will of the superior. Contract stipulates a transaction of goods or services; in covenant, theologically conceived, the superior party, God, makes a promise that will be kept regardless of man's response. (125)

Yet McGiffert himself cites the fact that Bulkeley uses contemporary worldly analogies

70 The political circumstances of this publication may be important. In 1640s England, the whole conception of covenant took on a vague nationalistic hue as unity became a military necessity. The Treatise, published two years prior to the Solemn League and Covenant of 1643 which established Presbyterianism in England and Scotland, appears to make way for the future use of the term as an act of political unity. At the same time, Ball's work was highly regarded in New England.

71 According to Klaus Baltzer, the biblical basis for what he calls the "covenant formulary" remains remarkably stable through its consistent "use in worship, preaching, and liturgy" (177). 
pertaining to contractual relationships in order to make God's relationship to his people as "readily understandable" as "marriage agreement, land conveyance, or contract of indentureship." These are, according to McGiffert, "poor simulacra of the covenant relationship, to be sure, yet offered by Bulkeley to clarify its nature" (113). McGiffert concludes his study suggesting that Bulkeley's own flirtation with contractual metaphors suggests "the ultimately irresistible slippage of Puritanism toward the order of contract" (129). Obviously, the idea of covenant is not self-evident, theologically speaking, and is beholden to the "poor simulacra" with a "slippage" toward human contractual relationships for its theological definition. ${ }^{72}$

Other scholars have found previous examples of attempts to relate the covenant idea through various worldly illustrations. Holifield points to the different metaphors early Reformers' used to describe God's covenant. Luther and Calvin liked to compare the covenant to a "seal" on a government document, while Zwingli preferred to associate it to a "military oath" by which an individual swore (in Zwingli's words) "to learn the divine precepts and to live his life in accordance with them." Later Reformers, particularly Ursinus and Beza, further developed their concept of the covenant by concentrating on the actual precepts- the actual "government document," or "Covenant." These precepts became the focus of what became a distinctively Puritan covenant theology brought to England following the Marian exile, ${ }^{73}$ by way of English dissenters and translated tracts. By the time the nonconforming (soon to be Congregational) migrants arrived in New England, the "seal" of the covenant referred only to the sacraments

72 Andrew Delbanco goes even further, accusing the New England Puritans of allowing financial analogues to invade their conception of the covenant, even while they resisted the idea of legal obligation in lieu of a tenant/master model of the human relationship to God. Eventually, in Delbanco's reading, the Puritan Medieval covenant ideal degenerated into "the imagery of finance," which served to subvert the originally intended meaning of the covenant from an oath of allegiance to a contractual exchange (Delbanco 61-2).

73 During the reign of the Catholic Queen Mary, many Protestant clergy relocated to the Continent, in particular the Swiss cantons of Geneva and Zurich. See MacCulloch, 280 passim. 
which, as we shall see, became at best a necessary redundancy to the original covenantal oath; New Englanders seemed, according to Holifield, to be much more interested in the contents of the "document" itself, rather than merely in its "seal" (Holifield 6-7, 126, 144).

David Weir hints at a further difficulty of translating terms for "covenant" in his analysis of sixteenth-century translations of the Bible. Before Tyndale's use of the English word in his translation of the Bible, translators had many interchangeable Hebrew, Greek, and Latin words to choose from for a similar meaning. The Hebrew term berith is the original term for the biblical covenant, and carries with it the meaning of a "treaty" between two nations of unequal power, a treaty which is usually forced upon the vassal state by its sovereign neighbor-buttressing McGiffert's above distinction between contract and covenant. ${ }^{74}$ Weir, however, found that the early sixteenth-century lexicons used by translators of the Bible consistently defined berith without reference to these actual treaties, instead relying on its more figurative use by the prophets which emphasized not an historical agreement between God and humanity but "the example of the coming ideal state." Weir contends that this transfiguration of the original concept of the covenant is evidence that, for the early Protestant translators, "the old covenant and even the new covenant are imperfect. What the Christian really wants is the everlasting covenant ... the covenant of God with perfected humanity after the Day of Judgment in the new heavens and the new earth" (Weir, Origins 52, 55). ${ }^{75}$ This would mesh with Walter Eichrodt's contention that covenant theologians aimed at something greater than just systematizing the use of the term berith in the Bible; berith was "only the code-word" for a much more expansive exegesis (qtd. in Kline 27n2). If this is correct, than Tyndale was following an established tradition in treating the

74 Berith is the word used to describe Noah's and Abraham's "treaties" with God-see the introduction for full discussion.

75 The favorite definitional text used by the lexicons, according to Weir, was Jeremiah 31:31-34, in which it is said that "the law of God will be written upon the heart of the believer and each man shall 'know the Lord.'" 
covenant "as the key to all the Scripture," as McGiffert maintains: "Whether seen as a unilateral divine promise or as a bilateral pact, league, bargain, or treaty-whether called foedus, testamentum, berith, or diatheke — covenant served a harmonizing purpose" (McGiffert, "Grace and Works" 469). ${ }^{76}$

In laying out the difference between the covenant idea as it has played out in the common Judeo-Christian heritage and shared biblical sources, and covenant theology and federal theology as distinct theological constructs that became prevalent within the Reformed Protestant tradition, Weir helpfully specifies the relationship between these theological terms:

Covenant theology grows out of the covenant idea. Covenant theology is a theological system in which the covenant forms the basic framework and acts as the controlling idea in that theological system ... The federal theology is a specific type of covenant theology, in that the covenant holds together every detail of the theological system, and is characterized by a prelapsarian and postlapsarian covenant schema centered around the first Adam and the second Adam, who is Jesus Christ. (Origins 3)

As early Protestant theologians worked out the final federal schema, many different covenants were proposed, so that, as Ian Breward says, "it is probably wisest to speak of a theology of covenant rather than covenant theology, so far as the sixteenth century is concerned" (qtd. in McKim 89). Even Baker, who claims Bullinger developed a recognizable covenant theology back in the mid-sixteenth century, admits that covenant as a "theological idiom" dropped out of

76 The harmony was not universal. Weir points to Sebastion Castellio's Latin translation of the Bible, which consistently bucked the Vulgate by using foedus (two-way compact) instead of testamentum (one-way command) to translate berith and diatheke (Origins 58-9). And according to Norman Pettit's reading of Tyndale, he "wove the covenant idea so thoroughly into strict predestinarian concepts that the promises were virtually smothered," suggesting that Tyndale's translation was not so much a harmonization as it was a revision (13). 
confessional use due to its specialized theological nature, not appearing in any Reformed confession until the Westminster Confession of Faith a century later (Baker, "Heinrich Bullinger" 368).

Jens Møller points to three major aspects of covenant theology—contractual nature between two parties, emphasizing more responsibility; continuity of history of salvation; and an escape from the law of $\sin$ (death) through grace — which he summarizes (in reverse order) as "grace, continuity, and obligation" $(47,55)$. Many scholars first identify in Zwingli in the early sixteenth century a progression from a unilateral testament-promise-based toward a bilateral contractual-covenantal-based relationship between God and mankind:

For Zwingli, with perhaps a different political model, the discussion of testamentum develops in terms of covenant ... a shift from emphasizing the sole divine initiative in the God-man relationship to giving the man-man relationship a bilateral component in the God-man relationship. (Hagen 22)

Olevianus, in the mid-sixteenth century, introduced the idea of the covenant of redemption as well as additional covenants with Satan and creatures, and most importantly the foedus creationis (covenant of creation) which bifurcated after the Fall into the foedus legale (legal covenant) and the foedus gratuitum (grace covenant), telegraphing the later distinction between the covenants of works and grace (Bierma, German Calvinism 183). It was not until the late sixteenth and early seventeenth centuries, particularly with the publications of William Perkins's A Golden Chaine (1590) and William Ames's The Marrow of Sacred Divinity (1627), that the fundamental bifurcation of the covenants of grace and works was fully developed and disseminated in England; these two books had a tremendous influence on the English Puritan 
movement, as they were read by most "earnest Christians," let alone Calvinists, in England during the first four decades of the seventeenth century (Lettinga 653). In addition to the theological covenants, many have ascribed to the Puritans derivative communal covenants, including a national covenant, a governmental covenant, a church covenant, and a marital covenant, as well as the "halfway" and renewal covenants particular to the New England Puritan experiment with church polity (Witte 590 passim).

Central to covenant theology as it came to maturity in the seventeenth century was the systematization of the covenants of works and grace. This is mostly due to the dual covenants' perceived ability to resolve the Calvinist unilateral and Zwinglian bilateral streams of thought on the covenant. Perkins proved most adept at fusing these differing covenantal strands together, explicitly emphasizing God's sovereignty while at the same time clearly laying out the covenant as God's "contract with man":

Gods couenant, is his contract with man, concerning the obtaining of life eternall, upon a certaine condition.

This couenant consists of two parts: Gods promise to man, Mans promise to God. Gods promise to man, is that, whereby he bindeth himselfe to man to be his God, if he performe the condition.

Mans promise to God, is that, whereby he voweth his allegeance vnto his Lord, and to performe the condition betweene them.

Againe, there are two kinds of this couenant. The couenant of workes, and the couenant of grace. (Perkins 32; see also Møller 58-9)

Here, "contract" and "promise" are used interchangeably and equally between God and man; 
however, emphasis on the conditional is fully situated on the side of mankind to "performe the condition."77 As a result, there continues to be disagreement among religious historians as to whether a true seventeenth-century synthesis of the covenantal scheme actually was accomplished. Some see Perkins and Ames leaning toward the more strict Calvinist line of unilateral covenant that leads Ames to the Antinomians, while others find that reconciling the conditional yet absolute aspects of the covenant concept within Calvinism "fails to hold without undue forcing once a careful analysis of seventeenth century writings is undertaken," making necessary the insertion of the un-Calvinistic Zwinglian Reformed tradition prior to Calvinism (McKim 85; Greaves, "Origins" 22).

The greatest and most revolutionary innovation of the seventeenth-century covenantal scheme, anachronistic as it may seem, is the "first" prelapsarian covenant of works. Miller early on identified one of the main goals of covenant theology to provide a secure place for the covenant of works:

[God] did not discard the covenant of works after Adam's fall; He included it within the covenant of grace ... no longer as a command, the literal fulfillment of which is required of man, but as a description of the goal of conduct toward which the saint incessantly strives. (Errand 82 )

However, McGiffert and other historians have emphasized not so much the moral law and code of conduct enshrined in the covenant of works - the Decalogue, which Perkins calls "an abridgement of the whole law, and the couenant of workes" (32) - as the enshrinement of conditionality, contractual relationships, and representative politics (one is tempted to add,

77 The Westminster Confession of Faith (1647), Chapter 7, paragraph 6, sets out the prelapsarian "covenant of works" and the postlapsarian "covenant of grace," the latter of which is further differentiated into its two administrations "in the time of the law and the time of the gospel," so in the end: "There are not, therefore, two covenants of grace differing in substance, but one and the same under various dispensations" (Schaff 618). 
materialism) as conceptually, even spiritually justified:

[The covenant of works] represented a conceptual transformation that meshed the history of covenant theology with one of the central issues of modern thought. The covenant of works, unlike the covenant of grace, became distinctive as a contract with the conditions of a legal quid pro quo relationship. It evidenced the tug of contractual principles upon the theological mind of the era. ${ }^{78}$ ("Grace and Works" 464)

These "contractual principles" would eventually lead to the revolutionary foment of the $1640 \mathrm{~s}$ when "King Charles' neck would lie upon a block hewn in part from the biblical matter of covenant" ("Covenant" 33). ${ }^{79}$ Greaves even goes so far to suggest blatant political motivations in the mid-seventeenth century for switches from the Calvinist unilateral to the Zwinglian bilateral covenant conceptualization:

It is possible that some of the Puritans were having second thoughts about a covenant with no real reciprocal conditions, when the idea of a covenant could be so easily transferred to the political sphere-a sphere where they found little resemblance between the earthly and the heavenly Monarchs. In this sphere it would certainly have been to their advantage to stress to their congregations the

78 In Origins, Weir takes up from McGiffert the emphasis on the covenant of works as the lynchpin of the entire federal theology, originating with the late sixteenth century Palatinate reformer Ursinus and developed by Olevianus, Cartwright, Fenner, and Junius until it came into widespread use after 1590. The prelapsarian covenant of works is differentiated from the postlapsarian covenant of grace, though there is no mention of the supralapsarian order of decrees which predestinate the entire sotierological process.

79 Speaking of the Puritan ministers in England, Paul Seaver almost by mistake captures the oblique impact of the Puritans from abroad:

But if they failed to reach their city on the hill, their passage across the dusty plains of mundane history was not without profound consequences. No people believed more in the efficacy of the Word than they, and if the Word ultimately failed to bring quite the revolution they hoped for, it nevertheless left a revolution in its wake, one as profound in its social as in its personal implications. (347)

The difference between these two revolutions, one "hoped for" and one "in its wake," rely specifically on the indeterminancy of what Seaver calls "the Word." 
idea of a covenant with conditions to be fulfilled by both parties. Surely their congregations were perceptive enough to make the implicit application of the analogy to the world of politics. ("Origins" 34)

However, the purpose of developing the covenant of works - again, without biblical precedent — was specifically to control the non-elect by providing a base for conditionality in order to preserve the unilateral status of grace ("Grace and Works" 466-8 passim). McGiffert traces the development of the covenant of works to the discovery by English theologians of "the weak link in the covenant chain" in biblical history between the Mosaic and Edenic covenants. In order to avoid the "vulgar legalizations" at the time being demonstrated by Separatists, Puritan theologians conceived of a covenant of works as an "antecedent to the covenant of grace" made, McGiffert claims, expressly to house "spiritual hypocrites" (McGiffert, "Grace and Works" $492-$ 3; von Rohr, Covenant of Grace 10, 38).

Thus, enshrining the conditional covenant of works within the unconditional covenant of grace protects those who are under the latter from those who are under the former. One can see this play out two ways in the representational politics of salvation, both expanding the field under Adam while reserving Christ for the truly elect: "The covenant of works is with Adam as representative of all mankind; the covenant of grace is with Christ as representative of the elect only" (Hill 6). However, the covenant of grace was created to fulfill the legal requirements of the covenant of works, which is permanent and holds sway over the entire covenantal framework of salvation. Thus, implicitly, the covenantal framework reserves all authority in the covenant of works; one can think of it as a bicameral legislative body that is essentially unicameral—more like the British Parliament than the United States Legislature—where the covenant of grace 
basically fulfills the terms of the covenant of works through Christ, but the covenant of works still operates as the fundamental legal basis for salvation. We can see, in the creation of the covenant of works as antecedent of yet subordinate to the covenant of grace, the Žižekian model of a "short circuit" at work, creating the conditions for one's own salvation, but only through a willful act of predestination.

This dialectic between the covenants of works and grace had a major impact on the initial church covenant relations and the Antinomian controversy in early New England, extending into the late seventeenth century and beyond. A century after Perkins and a continent away, Samuel Willard in Covenant-Keeping the Way to Blessedness (1682) takes up the relationship between the covenants of grace and works - "at the heart of all the contentions in the New England Churches," says Increase Mather in his Preface — and employs the same "ingenious shift of focus to the positive aspects of the covenant of works" (Elliott 165). The covenant of works was created to serve as an all-encompassing insurance policy for the more elite covenant of grace. Instead, the covenant of works became the embodiment of the covenant of grace — or rather its own negation within the covenant theology structure. Here we see Žižek's Pascalian theory of belief, the "materialism of grace," which he claimed to be non-theological, directly enacted within the theology of Reformed Protestantism.

We should note that the covenant of works, as the primary and primordial covenant within the covenant theology framework, holds an unstable temporal relationship with the earliest Old Testament biblical covenants—-specifically, the Edenic and Noaic covenantscollectively known as "the covenant of creation" or "the covenant of nature." William Stoever describes the early New England controversy with the Antinomians as an enactment of the 
dialectic of nature and grace in covenant theology, where the covenant of works, as part of creation, is therefore not completely under Satan. In the divine "natural order," then, the "natural" form of the covenant itself takes its shape from the idea of God's "works." Because of the covenant of works' prelapsarian origin in history, it is universally applicable to all of mankind, and thus "takes on a greater weight" than the postlapsarian covenant of grace. Grace, moreover, was instituted by God as a remedy for the fall of mankind, and can be seen as merely "the covenant of works in disguise." Since the original covenant "can never be broken" (making Christ's mediation necessary, yet—remember Žižek's joke—only just), humanity still lives under its yoke. It could therefore be said that, under the covenant of works, "man now becomes basically a legal creature from the very beginning —at creation" (Weir, Origins 5-7, 22; Stoever 90). Stoever summarizes this point nicely:

In Puritan covenant theology, the terms and the form of God's dealing with mankind for salvation are established in the covenant of works at the foundation of the world, and the covenant of grace functions as a means of applying to the elect the righteousness obtained by Christ, who satisfies the conditions of the first covenant. (96)

God "imputed" Christ's righteousness to men, but the "condition of this imputation," Stoever maintains, "is a human act: namely willing acceptance of the offer of Christ's righteousness, together with a vow of renewed obedience to this moral law," the covenant of works. Thus, the covenant of grace can be seen as fulfilling the same function individually that the later New England Puritan covenant renewal rite served communally, adapting the covenant form to serve a new, more political purpose — one might add reversing form and content, in keeping with Žižek's 
theoretical formulations of grace. ${ }^{80}$

While Stoever is right to conclude that "the covenant of grace takes its form from the covenant of works, as a mutual transaction involving a willing act on man's part" (96), we can add that the new form of the covenant of grace adapted the covenant of works to inspire different "willing acts" on the part of the believer. God must "will" a man to be elect, and then supply him with means to "transact" with God, thus providing the means for an individual to choose God, having already been chosen by God to do so. A mutual transaction is required, but God's sovereign power to act "on man's part" is maintained in the form of a human "willing act." In Žižekian terms, a subject must freely predestine oneself into a free existence through a passive act of being chosen.

This can best be described by drawing on a passage in Thomas Hooker's sermon "The Paterne of Perfection," which begins with his contrast of the covenants of works and grace by stating what appears to be the obvious, that "a covenant implies a covenanting, not with a mans selfe, but with another" (210). He goes on to point out how this basic approach to covenanting for Adam in the covenant of works gets complicated when we get to the "second covenant" of grace:

[Adam] had a power and principle in himselfe, to keep Gods commandements. Adam had an uncontrollable liberty of will, whereby hee could begin his own worke ... But it is otherwise in the second covenant; wee must see ourselves lost in regard of our owne ability to service, and therefore wee are bound by faith to go out to another; which Adam needed not. (213-4)

${ }^{80}$ McGiffert vehemently disagrees with this transposition of covenants, for "the covenant of creation (epitomized by the postdiluvian promise to Noah) was always defined as an absolute promise, a sort of temporal covenant of grace" ("Grace and Works" 492-3n70). 
Adam, fully present in himself, had the ability to form a covenant with God, as his own party. In other words, Adam was not in need of representation, even though his acts through the federal scheme represented all mankind. Thus, we have a fundamental contradiction in that Adam is held as representative of the human race that, without his fall, would have required no representation, being one would assume as fully present in themselves as Adam. Once Adam falls, he falls into representation, becomes not himself, no longer self-present, but a representative of all mankind, and all mankind in turn falls into a double representative framework, both damned through Adam's fall and saved through Christ's fulfillment of the covenant of works. The covenant, however, becomes troubled, in that it only fully works within the covenant of works framework. One can, thus, understand Hooker's tautology in his next sentence, "It may truly be said, that Adam had something of his owne." Adam was only free when we was "his owne," and yet such a freedom is always already foreclosed due to the fundamental dual nature of Adam's representation of humanity, creating a tautological bind of self-definition that will take someone like Emerson to work out.

Reformed Protestant theology was fully engaged in attempting to make these complicated formulations make sense. One can see this most directly in seventeenth-century understanding of the covenantal framework in relation to the full deployment of predestinarian logic: the "order of decrees." The double-predestinarian High Calvinists, who believed that all mankind was either predestined to be saved or to be damned, were split into two differing interpretations over the order of divine decrees concerning the creation versus the salvation of man. Basically, the infralapsarians put creation before the scheme of salvation, while the supralapsarians put the scheme of salvation before the creation. In other words, for the supralapsarians God created man 
in order to play out the scheme of salvation and damnation; mankind's foreordained role is to be a demonstration of divine justice (Weir, Origins 19). This created disagreements on which of the covenants, works or grace, came first. The supralapsarians believed that the covenant of grace came first, predetermining the ending failure of the covenant of works as it was played out in the Garden of Eden. Greaves identifies some doubts and disagreements about the nature or even identity of the covenants of redemption and grace in the mid-seventeenth-century theological literature. Strict Calvinists and Antinomians directly related these two covenants together as underpinning their supralapsarian scheme ("John Bunyan" 157). ${ }^{81}$ From the supralapsarian viewpoint, the covenant of grace only makes sense with the fall; Adam is not Adam, and the covenant is not the covenant, without it. The view of the "Strict Calvinists" prevailed in New England, and provides a vantage point from which to understand the mental acrobatics required to understand God's anachronistic and anti-intuitive relationship with mankind. Predestination is, in the end, a violation not just of human freedom but of temporal order and causation itself. The covenant was, therefore, meant not to contradict predestination-no matter what one thinks of it, its logic is sound - but to ground it in human, political meaning.

The covenant concept is theory (theology) at its most pragmatic level, in its attempt to put into practice a radical, mystical, metaphysical theology of grace. The result is a birth of a modern politico-theological concept that provides rational basis for irrational realities. In doing so, however, the covenant concept performed a necessary shift from providing a strictly objective contractual corollary of the divine plan for salvation to representing a more subjective and vaguely defined relationship between a spiritual community and its God:

\footnotetext{
81 According to Greaves, John Bunyan simply considered the Covenant of Redemption as identical to the covenant of grace, thus "solving" the issue of mutuality inherent in the concept.
} 
Puritanism ... even as it moved to stress the importance for assurance of the objective Word, sacraments, and covenant, found itself tied again to the definition of subjective criteria and the search for qualification. Perhaps this is unavoidable when final focus is not on the reality, but on a relationship. (von Rohr, Covenant of Grace 182)

This subjective relationship required qualifications and constructions that, at times, defied logic; however, as Hoekema claims after pointing out the unresolved logical tensions inherent to Calvinism, "A theology faithful to Calvin must always be willing to grant that logic never has the last word" (135). In this way, though they (let alone Miller) would never admit it, the New England Puritans were the most Calvinistic of Calvinists - and, in their constant attempts to have the "last word," the most literary-critical of our forebears.

\section{Practice of the Reformed Covenant - Grace at Work}

The New England Puritans found themselves with a unique opportunity to enact their covenantal framework in the earthly and temporal sphere. ${ }^{82}$ As we would expect, having explored all the various logical conundrums associated with covenant theology, they were immediately faced with significant conceptual as well as political challenges that arose directly out of the theology of the covenant. As Stephen Foster aptly points out:

New England, however, was not just a fulfillment of unrealized English Puritan aspirations; it was also a continuation of the duality between the insular and the comprehensive that had always been at the heart of the movement. (27)

\footnotetext{
82 Miller found that the New England Puritans "can be isolated for the purpose of study as Puritanism in England cannot be" (NEM:SC 91).
} 
This "duality" between the universal covenant of works and the selective covenant of grace is the primary unresolved tension that could not help but complicate the political enactment of the covenant, and led to adjustments in covenantal polity that directly impacted the conceptual matrix of the divine covenants. This is reflected in their literature, which we will now have an opportunity to more closely analyze from a theoretical, if not a strictly theological, perspective. It is my argument that the unique history of covenant theology in seventeenth-century New England, as evidenced in the church "relations" and the Antinomian challenge, led to an unforeseen political conceptual framework that would continue to work itself out in the coming centuries. $^{83}$

One of the first logical conundrums that the New England Puritans faced was how to directly reflect the divine covenant relationship in the politics of church and state. John Winthrop famously expresses his easy distinction between "the lawe of nature" or "the morrall lawe" and "the lawe of grace" or "the lawe of the gospel" in his sermon "A Modell of Christian Charity" which inaugurates the colonists' enterprise. It is important to note that he sites these laws without reference to the well-established covenants of works and grace, relying instead on his hybridization of the more generally understood natural law theory. He instead reserves the term "Covenant" to later describe the "speciall Commission" of the New England colonists:

Thus stands the cause betweene God and us, wee are entered into Covenant with

83 We should note that there is significant skepticism among current historians as to the influence of Puritan New England theology and even church practices on American religiosity, let alone literary or political history. Charles Cohen, in "The Post-Puritan Paradigm of Early American Religious History," summarizes the reason for shifting interest in early American religion studies from Puritanism to pluralism:

The problem with characterizing colonial religiosity primarily in terms of one clergy's doctrine lay not in elevating irrelevance, for few historians even now would gainsay Reformed Protestantism's hold on New England's worship, but in misconstruing a college town as the omphalos of faith. (696) My continued emphasis on the enduring modes of Puritan meaning can be understood as resisting the move to a "post-Puritan paradigm" of pluralism, in alignment with Žižek's emphasis on "universalism" in critical theory. 
him for this worke, wee have taken out a Commission, the Lord hath given us leave to drawe our owne Articles wee have professed to enterprise these Accions upon these and these ends, wee have hereupon besought him of favour and blessing: Now if the Lord shall please to heare us, and bring us in peace to the place wee desire, then hath hee ratified this Covenant and sealed our Commission, and will expect a strickt performance of the Articles contained in it, but if wee shall neglect the observacion of these Articles which are the ends wee have propounded ... the Lord will surely breake out in wrathe against us ... and make us knowe the price of the breache of such a Covenant. (294)

This lesser-known pretext to the famous "Citty upon a Hill" phrase in the following paragraph, lays out in belabored metaphoric terms the stark conditions, or "Articles," of the covenant between the colonists and God. This covenant is purely voluntary and bilateral, and is openly extra-biblical, drawn up by the colonists themselves - a point Winthrop repeats twice for emphasis - prior to God's ratification. The covenant's content, its "Articles," are in fact the political enactment of covenant theology itself, "to seeke out a place of Cohabitation and Consorteshipp under a due forme of Government both civill and ecclesiasticall" (293). However, this covenantal content is sidelined by Winthrop to "these and these ends" in the penultimate passage of his sermon so he can stress the structural point of the covenant's binding nature. Thus, the establishment of covenant theology requires the pre-establishment of a more broadly political, artificially constructed corporate covenant that encompasses a special communal relationship and responsibility between the New England "Modell" and God.

For the New England Puritans, federal theology denoted not just the representation of the 
first and second Adams in the covenants of works and grace, but also the covenanted relationships of individuals with God as well as collectivized covenants of churches with God. As covenant theology is often considered the genius of Reformed Protestantism, the New England Puritans' development of the "church covenant" is considered, for all its difficulties, the genius of their particular brand of the Reformed faith. Theodore Bozeman cites the definition of "Church Covenant" in the Cambridge Platform of 1647 as equal to "the Covenant ... which made the Family of Abraham and the children of Israel to be a church and people unto God" (129). ${ }^{84}$ How they were made into a "church," however, is a complex issue. Each church was instituted through a founding church covenant document. Not so surprisingly, the extant church covenant documents are remarkably unremarkable: similar, short, vague, and hence uninteresting. ${ }^{85}$ This "form," however, is important for ascertaining the immediacy of the covenant's reference in biblical practice. For the Israelites, Delbert Hillers explains, "Yahweh our God made a covenant with us in Horeb" (Duet. 5:2), which he says "referred to something that had actually happened — the text of the agreement was in a box in the temple." This made the covenant with God "more

84 Bozeman, along with many other scholars, associate the early New England covenantal ideals and practices with an overarching "national covenant" which was "related most directly to the task of sustaining reformation in early New England" (291). Bozeman links this covenant directly to the "Deuteronic" covenant in the Bible, though he might as well have cited the "Davidic" covenant (194-6). I disagree with this association due mostly to the fact that the Puritans at that time did not consider themselves forming a new nation but instead attempting to reform their home nation of England.

85 For example, Salem's church covenant, which was the first church covenant in the colony (1629), is one sentence:

We Covenant with the Lord and one with an other; and doe bynd our selves in the presence of God, to walke together in all his waies, according as he is pleased to reveale himself unto us in his Blessed word of truth.

Williston Walker finds that all early Congregational church covenants were similar in "simplicity" and "brevity." The Salem church renewed the covenant seven years later, creating a lengthier document to take the place of the original (116). Many church covenants are available, but the research on them is slight. David Weir's Early New England: A Covenanted Society (2005) is a wonderful recent exception, an in-depth analysis of church and governmental covenant documents in early New England. Though I make little use of this work in this study, which is more focused (as he puts it) on "larger questions of the emergence of the modern American political tradition" (14), his book is an invaluable and long-overdue addition to the history of the covenant idea in early New England. 
than an idea to Israel" (5). The New England Puritans, on the other hand, did not depend on their church covenant document in the same way. Each of these extant covenants blandly asserts the purpose of the church as a support mechanism for each covenanted member's individual covenant relationship with Christ. Thus, the earth-bound church did not establish the "true" Church of Christ, but only gathered together those deemed holy enough to be possible members of Christ's body. The definition of "church" was thus blurred along with the definition of "covenant," in that neither could be determined. God's "seed" became theoretical, as far as human judgment was concerned.

The admixture of the church covenants within a general covenant theology created significant discomfort among fellow covenant theologians back in England who, especially in the 1640 s, were experimenting with their own usage of covenant theology for political purposes. John Ball, quoted above, delineates the metonymic tautology of how "the Covenant includes the whole reason of the Covenant with the circumstances: but the name sometimes is attributed to some circumstances." Ball was one of several Presbyterian ministers who challenged the New England "Church-Covenant" practice as extra-biblical and possibly unlawful. John Davenport, in 1639 , countered by differentiating between the necessity and lawfulness of the church covenant practice:

Some indeed have questioned the necessitie of our Church-Covenant, but none (we hope) of thesse our reverend brethren that we write unto do question the lawfulnesse of such a Covenant being nothing else for the matter of it, but a promise of doing such Christian duties as the Gospel of Christ requires of all Saints in Church-estate. (75) 
John Allin, in the same exchange, differentiates not only the church covenant from the legal validity of the divine covenants, but also from the legal liabilities associated with oath-taking, strongly related as it is to the ancient source-rite of "cutting a covenant":

[I]t is far from our practise to use any Oath in our Covenant, and strange to us to read so many Pages against our Church Oath, and swearing to the Covenant, to make our courses horrid and too too rigorous. (13)

It is clear that for the New England ministers in the mid-seventeenth century, responding to the Antinomian crisis and the revolutionary foment back home, publicly characterized their church covenant practice as on a different level than the divinely ordained covenantal structure of grace; this is perhaps due to its clearly conditional, bilateral, and even voluntary dimensions and practice, leading to Richard Mather's necessary (if surprising) inference of "morall equitie" associated the gathering of churches under a "mutuall free covenant":

For, that a company should be combined together into one body, in way of Government and subjection, by way of mutuall free Covenant; as men doe when they enter into Church Estate, nothing is more naturall or agreeable to morall equitie; nay, it implyeth a contradiction in the very name of libertie or freedome, that free-men should take upon them authorities or power over free men without their free consent, and voluntary and mutuall Covenant or Engagement. (9)

Needless to say, as covenants go, conditionality must be in some way inferred, as Mather makes perfectly clear in his consistent use of the conditional or mutual covenant to discuss the function of the corporate church covenants: "wherein a man voluntarily takes on him a new relation, there it always implyes a Covenant, whether the relation be morall and civill, or religious and 
Ecclesiasticall" (21). One is not surprised when almost immediately the practices and preaching of ministers under the church covenant form came to be challenged by other Reformed theologians as far too directly associated with the conditional covenant of works.

\section{Covenant Relations}

The development of the church covenant structure for properly instituting "religious and Ecclesiasticall" order created fundamental challenges, especially as they were tasked with mirroring the divine covenant within their church membership. Holifield, in a thorough study of the practice of the sacraments in New England, found that the covenant and the rite of baptism, often called by Puritan writers the "seal" of the covenant, became the conflicting means for becoming a member of a covenanted church in the seventeenth century. "Somehow baptism ratified God's covenant promise," but baptism's necessity remained unclear. "Ambiguity pervaded" in New England; there was a "common ambivalence" among their theologians concerning baptism; "after 1630 Puritans seeking a viable doctrine of baptism had a wide selection." During the time of migration to New England, and subsequently in the colony, no one knew what baptism in fact "sealed." The church covenant, on the other hand, was strenuously affirmed, usually at the expense of baptism as the sole criterion of church membership. Perkins maintained that, while the covenant is the "foundation and substance" of baptism, baptism in turn is "only a seale of that covenant, and no more." Ames went so far as to affirm the covenant before baptism as the actual "seal." Holifield also cites Richard Mather's "common New England belief" that "to bring in Baptisme before the Covenants and before the Church, with whom God makes the Covenant, and then to bring in the Church afterwards, is to make Baptisme a seale 
unto a Blanke, or to a falsehood." The covenant, by necessity, superseded the baptismal seal, and seemingly made baptism into an unnecessary ritual needlessly reasserting a theoretical inclusion in Christ's church. Except for its biblical precedent, and the desire of members to affirm their children's inclusion in the church, Holifield suggests that the sacrament's practice in New England would have died out altogether (26, 41-7, 65-76 passim).

Across New England, "relations," or personal testimonies of conversion, took the place of baptism as the "seal" of membership, and baptism was relegated to "the personal possession of a spiritual aristocracy." This, for one, made it difficult for babies to be baptized (as their parents would have liked), and also threatened New England churches with a loss of "all resemblance to the baptismal traditions of historic Protestantism." It is repeatedly affirmed by Holifield that, though baptism was essential as a "guarantee" of God's fidelity, God's actual promise was the covenant as defining the invisible church, for which the visible church is the mode of conveyance (144-5). ${ }^{86}$

The content of God's promise, however, was remarkably vague and prone to selfreferential tautologies surrounding the conditionality inherent in the unconditional covenant. As Coolidge summarizes, "If you are in the Covenant, then you will certainly perform the conditions of the Covenant. Conversely, if you perform the conditions you must be in the Covenant" (125). Identifying whether one was or was not within the covenant proved to be the most challenging aspect of the Puritan conversion experience, and some of the most involved early books to come out of New England engaged this issue directly. Thomas Shepard's The Sincere Convert (1641) starts the converts out by challenging their inherent atheism and works its way through their "misery," "difficulty," and false "confidence" to an ending that can only be interpreted as a never-

${ }^{86}$ For a full-length discussion of the "visible" and "invisible" church construct, see Morgan. 
ending question mark. Thomas Hooker, on a more hopeful note, developed a series of sermons that scientifically detailed the "preparation" of sinners for conversion; his innovations nearly got him into trouble, similar to John Cotton, with his fellow New England ministers. McGiffert attempts to explain this phenomenon by hearkening back to Perkins's transformation of covenant from theology to piety, giving it a literary essence by propelling it forward through his sermons, which had a profound effect on the future colonists:

Perkins thus transformed the covenant into a compelling metaphor for the profoundest religious experience. What puritanism received from him was less a covenant theology than a covenant piety of rich resource, with all the assurances of grace and inducements to godliness that piety abundantly supplied. ("Grace and Works" 500)

In other words, covenant theology worked as a theology precisely by not working as a theology, but instead like an expressive piety built on compelling metaphors—something recognizably literary, but of a form all its own.$^{87}$ The covenant provided an expressive means, if not a theologically (or politically) consistent metaphor, for the performance of individual religious devotion, which in turn, hearkening to Žižek's Pascalian logic, created the "means" for the devotion in the first place.

The body of work where we can find this "covenant piety" most readily expressed, therefore, is not in the Puritan ministers' sermons so much as in the relations of their church membership. However, in reading these relations, one immediately notes the importance of the sermons in providing the structure for their description of their sense of salvation. Emory Elliott,

\footnotetext{
7 Caldwell attempts to identify in conversion narratives, like the relations documented by Shepard, the introduction of a particular mood or "feel" as one possible beginning for American literature.
} 
in Power and the Pulpit (1975), attempted to reconstruction the "Puritan Unconscious" which was shaped to be receptive to the literary efforts of Puritan sermons. While Elliott's work is primarily sociological, I would argue that a close reading of these relations may help us reconstruct the unconscious of the covenant concept itself, demonstrating how its work created the gracious belief at the unconscious level. ${ }^{88}$

All of the extant relations come from Thomas Shepard's notes taken down during the ceremony when those applying for church membership would describe their conversion experience ${ }^{89}$ The conversion experience, contrary to assumptions we may have in our postPentacostal age, was for Puritans "a hard, long, and always reflective business, more often than not pursued in company," with a significant amount of coaching from one's minister, combined with discussion with church members and the hearing of others' relations (Foster 24). And, as we'd expect from parishioners of the author of Sincere Convert, there is no fixed moment identified in any of these relations where the convert knew that their salvation was assured: Doubts pervade these stories; worries abound. The confessors have been running —are still running — a broken course that zigs and zags from anxiety to assurance and back again. Their anxieties stand out sharply; their pain is evident. Their assurance, by contrast, seems transient and incomplete—as indeed, in Shepard's spiritual calculus, it was supposed to be. (McGiffert in Shepard, God's Plot 140)

88 Elliot's thesis is that an enforced lack of "self-trust" in Puritan children led to a psychological "inner division": A consideration of the Puritan discouragement of self-trust in children suggests that Puritan children were likely to suffer from an acute lack of self-trust that evidenced itself in expressions of "inner division and universal nostalgia." (78)

89 For modern published versions of these relations, see Shepard, "Confessions"; McCarl 441-66; Shepard, God's Plot 149-225. One should note the third-hand and dubious status of these "texts," which were first transcribed from the applicants' oral relations, or testimonies, then re-transcribed from what Bruce Woolley calls "the horrors of Thomas Shepard's crabbed penmanship" (Preface to Shepard, "Confessions" xi). For a good description of the physical and emotional circumstances within which the relations took place, see Michael McGiffert's "The People Speak: Confessions of Lay Men and Women" in Shepard, God's Plot 135-48. 
In fact, as evidenced in contemporary spiritual autobiographies as well (including Shepard's), "self-accusation could be used as its own refutation," in that the more one doubted one's own salvation, the more that salvation was assured — thus in some way ameliorating the "continuous agony of unresolvable doubt" (Foster 71). Their way of expressing this doubt, as well as their development as a convert, is through reference to biblical texts and sermons (especially Shepard's, who is sitting in the room) and, though very few use the word "covenant," they are constantly and intertextually working through the conflicts inherent in the theology of the covenant. $^{90}$

One aspect of the unconscious covenantal framework that continues to appear in these relations is the tautological identification between the unilateral and bilateral covenants. In Elizabeth Oakes's confession, we see this direct relationship described:

And Mr. S[hepard] preaching in John, All that were called not elected, and how shall I know whether I was elected, and I heard if the Lord gave the soul a heart to choose Christ, Christ had chose[n] Christ [sic] before. And I thought the Lord gave me a heart to choose him above all things here in this world. After the Lord giving me a heart to seek him to enjoy him in all his ordinances, I thought I was so unfit and unworthy that I was unfit, and I heard that some might not find God because they did not seek him in all his ordinances, and that the Sacrament was a

\footnotetext{
90 One of the few times where covenant is cited is in Alice Stedman's relation, for whom contemplation of the concept provides little comfort:

And thought I saw it was thus and thus with me, yet I could not believe. and when Mr. Buckly taught here out of the 17 of Genesis that great God should enter into a covenant with him [Abram], I was content the Lord should make what covenant he would, especially Abram then falling upon his face. Yet I could not believe. (Shepard, God's Plot 188)

One other commonality that runs through many relations is a frequent mention of the impact of coming to New England; for example, Elizabeth Dunster describes, "And when I came over seas, I had God's presence. I was assured I was where God would have me, and so I submitted" (McCarl 466).
} 
means wherein the Lord would coming [sic] more. (McCarl 442)

In a brilliant inference (note the modern editor's uncertainty), Ms. Oakes derives from Shepard's sermon that the only way predestinarian logic works is if "Christ had chose[n] Christ [sic] before," making an a priori judgment for her own salvation. Her qualifications or "fitness" for this choice on God's part is doubted in duplicate- - "I thought I was so unfit and unworthy that I was unfit"—which is a veiled critique of God's judgment. Her only recourse is to the "Sacrament" (one assumes baptism) as a means of increasing the efficacy of God's judgmentnot, we should notice, as a seal on that judgment. Similarly, John Shepard (no relation), also derived from a sermon a fundamental tautology, "You have not chosen you [sic]," followed by a citation of Christ's love which is free and thus somehow limited and in need of being "clear[ed] up":

Now after this, Mr. S[hepard] came to show John 15: 16, You have not chosen you [sic]. Doctrine: Greatness of Christ's love is seen in the freeness of it. At which time, being in great trouble for want of love and fear of God's love, not knowing what would become of me, and I promised him if he would clear up his love, I would cleave to him and walk in his way, and after my resolution was to continue seeking for mercy. (McCarl 444)

This understandable search for clarity is directly addressed to the existentially frightening "freeness" of God's love — the deterministic lack of predictability associated with the concept of grace.

Contrary to Miller's assertion that the covenant of grace smuggles simple conditionality into the divine relationship with mankind, the New England confessors make pains to point out 
the complicating lack of conditionality in this relationship. Edward Collins, for instance, describes discovering the Puritan message in Dedham, England:

And there I took notice of covenant, that it was free, and saw promises made to such dispositions - to lost, to meek and hungry and thirsty, and to such as were confessors and forsakers of sin, and hence I thought Jesus Christ was mine and so stayed my heart. And in searching my heart, seeing sin die and growing in grace, and I thought God would carry on his own work. (Shepard, God's Plot 179)

Here we see the intermixing of the unilateral covenant of "promise" with the required receptive "dispositions" preexisting in the believer's heart as a result of God's "own work."

The disposition cited here—lost, meek, hungry, thirsty—are those associated with the biblical poverty of spirit, with being without, the necessary unwilled precursors to God's "work." Similarly, in John Sill's relation, we see a direct struggle with the unilateral conditionality inherent in the covenant:

And then the Lord helped him to look toward him by that means, Isaiah 50:12 he that heareth and obeyeth, let him trust in the Lord and stay himself upon God. This stayed him. And here he found much hardness, deadness, and seeing many promises made, but conditionally made, his heart stood here. But at last he saw the Lord had promised to work the condition and hence in the sense of the want of the condition to go to the Lord to work it. (156)

Mr. Sills, in "want of the condition," unable to discern the means of salvation among so many "promises ... conditionally made," relies eventually on God who "promised to work the condition" to the benefit of the believer. In other words, the conditionality inherent in God's 
promises must be worked through by God in order to become recognizable (and reliable) as the promise of salvation. Mary Angier Sparrowhawk describes in like manner how she comes to realize her lack of sufficiency as itself the condition of her "closing" with God:

And after this, a question made whether she had closed with person of Christ, yet she saw if she had not, yet she saw the fault was in her. And then that place-fury is not in me, let him take hold of my strength — and she saw that strength was Christ. And she [saw] there was but two ways, either to stand out or take hold, and saw the promise and her own insufficiency so to do. And that other scripture- - he had laid salvation on Christ —and she thought now she closed. (171)

Her choice, either to "take hold" of Christ's strength or refuse, is answered by the duality of God's "promise" and her own "insufficiency," meaning her choice was not to choose, but to instead allow God's promise to fulfill the choice, "work the condition." God's "free grace" is system of salvation in which only God can play through our lack of choice.

John Stedman helps to translate this dynamic back into the covenantal grace and works framework,

After I was troubled for want of growth ... and hence feared I wanted grace. But I felt my heart longing after grace and want of grace, and that was poverty yet, and this supported [me] ... After this I questioned my estate and came to New England, and hearing Mr. C[otton] speaking how far a man might go under a covenant of works, and so had great fears that was my condition and not sleeping quietly that I had received Christ nor could find no sense of my need of Christ. And after many weeks I came by providence to this place and heard 2 Corinthians 
5:20 treating about justification and calling. God spake to me as if I had told him and so found my hardness of heart subdued in some measure. And since have been carried through many fears and doubts. (173)

We see Shepard here cleaning up some of the damage associated with John Cotton and the Antinomian's assertions that many who think they are under the covenant of grace are really under the covenant of works (see below). To give Cotton credit, this is a significant problem for covenant theology; the covenant works only by conceptually inverting one's notions of unilateral promise and bilateral conditions, so that God's promise is to work through the conditions of one's salvation, to essentially save Himself. (We are reminded that, in Žižek's formulation, grace is the enactment of God's death in becoming a community of believers, and thus receiving grace is simultaneously an act of giving up, of receiving God's loss of Himself.) The only requirement for the believer is to remain in "poverty," to have "great fears" concerning one's "condition," and to listen for God's voice, which must at the same time sound familiar_ _"as if I had told him"_ suspiciously similar to what one would expect one's self to say. In such circumstances, it is quite reasonable for believers to be "carried through many fears and doubts" by simply assuming one's own damnation, similar to what Robert Holmes suggests in his relation: "Still I am doubting, but I know I shall know if I follow on, and if he damn me, he shall do it in his own way" (195). The poverty of the covenant framework is its strength, in providing an indeterminate avenue for determining one's predetermined salvation or damnation, to be found out always already after the fact; salvation, in a real sense, is "know[ing] I shall know," performing the unilateral promise of simply finding out if one is saved. 


\section{Covenant on Trial}

The Antinomian controversy of 1636-38, occurring just four to six years after the colony's founding, demonstrates the tensions associated with the ambiguous theological relationship of the covenants of grace and works through its "remarkable degree of theological give-and-take" (T. D. Hall 197-8). As opposed to the "strict Calvinists," who viewed the unilateral covenant as a testament or promise but saw moral law as needed if not determinative, Antinomians thought the moral law should be fully abrogated under the fully unilateral covenant of grace (Greaves, "John Bunyan" 152). Baker provides an excellent summary of the balancing act ("tight rope") that the New England Puritans tried to walk between the Antinomians and the fully conditional (and universal) Arminians:

[T] he later Puritans made a conditional covenant out of Perkins' covenant (testament) of grace. The basic condition was faith, which further obligated the believer to live according to the law (the covenant of works). Sanctification thus became the seal and assurance of election. This tight rope walk between Arminianism and Antinomianism did not deny the absolute election or the free grace of God. Rather it affirmed both the free grace of God and the responsibility of man, thus enabling the Puritans at the same time to hold firmly to absolute election and to emphasize the necessity of living according to God's law. (Baker, Bullinger 214) ${ }^{91}$

Antinomianism is most properly understood as "hyper-Puritanism" born in the early seventeenth century in reaction to the Arminianism. Anne Hutchinson, who followed her minister John

\footnotetext{
91 For Baker, the New England "tight rope walk" resolved double-predestination's "paralysis" of covenant thinking through the reintroduction of Bullingerian conditional covenant motif ("Bullinger" 376).
} 
Cotton to New England, figured most prominently in the controversy, holding meetings after church services to discuss the sermons, eventually recreating the ceremony of relations in reverse, "dissecting the personal experiences delivered by would-be saints to show them that they were still unconsciously relying on a covenant of works" (Foster 162-3).

The Antinomian controversy is most often characterized as one less about theology than freedom of conscience, "the struggle between the forces of individualism and conformity" (Barnstone et al xvi). Adams, the first collector of the documentary materials concerning the controversy, went so far as to say that controversy "could not be properly appreciated if it were approached from a theological point of view" (qtd. in D. D. Hall, Antinomian 10). I would argue the exact opposite: that theology made this controversy possible, is the only way to understand not just its historical specificity but its abiding interest as a touchstone of American selfunderstanding. Stoever, in a book-length study of the controversy, would seem to agree, seeking to demonstrate that the covenant of works theology created a dialectical relationship between divine grace and created nature that helped resolve the theological tensions associated with the conflict. Once again, I hope to show that the covenant of works has precisely the opposite effect, representing the very site of conflict endemic to the covenantal structure and covenant concept itself.

The most explicit theological discussion of the controversy was over the sixteen questions posed by the elders to Cotton. ${ }^{92}$ Cotton gave the lengthiest treatment to Question 13, "Whether evidencing Justification by Sanctification, be a building my Justification on my Sanctification: or a going on in a Covenant of Workes." Translating this awkwardly stated and jargon-filled

92 For a more broad discussion of this interchange, see Stoever, Chapter 3. Overall, I disagree with Stoever's use of dialectic and his assumed integrity of the covenantal system, which comes across as an apologia for the Puritan belief system; however, his analysis of the controversy is comprehensive. 
question, the elders wanted to know if Cotton would allow believers to rely on their sanctification, their evidence of election through earthly good works, to buttress their justification, or surety of election and salvation through God's grace. Cotton replied that, in doing so, one ran the risk of substituting the covenant of works for that of grace, regardless of one's justification. According to Cotton, one's soul can be justified under the covenant of grace, but seeing no evidence of justification, may "goe aside to a Covenant of Workes" in order to appear sanctified (and justified) before one's time. He likens this situation typologically to Abraham "going aside" to Hagar in order to have a son (sanctification), regardless of God designating this role to Sarah (justification). Thus, even the Elect can be led to confusion and "sad Doubts" through what can only be described as covenantal infidelity (D. D. Hall, Antinomian 55-6).

The elders' answers are understandably snippy (while maintaining scholastic form) in their response to Cotton's answer to Question 13, saying his high standards even for the Elect necessarily result in some awkward judgments on the actions of biblical figures:

Then these five things seem to follow ...

1. That David did ill to confesse his sin ...

2. That then the Lord hath done ill to command his people to humble themselves and pray ...

3. That the Apostle Peter hath sent us aside unto a Covenant of Works in exhorting us to use all diligence ...

4. That Christ hath done ill to command us to pray for the Spirit ...

5. To seek assurance from a divine witness ... is a going aside to Hagar. (72-3) Having expended this rare bit of sarcasm, the elders ask Cotton to be reasonable and allow the 
provision of comfort to those who "feel it not" by "better instruct[ing] in the Covenant of Gods free Grace, not to be condemned as going aside to a Covenant of Works." The divines register their objection to Cotton's use of both typology and terminology:

As for the Alegory of Abraham and Hagar, it will not prove what is here said, but thus much only, That for any man to go aside to a Covenant of Works ... to seek to see the promised seed there, is to go aside to a Covenant of Works: But to seek to see the Lords face by seeking to feel the Lords own Work in us, is not going aside to Hagar. All doing or use-making of Works implyes not straightway a Covenant of Works. And we cannot but disrelish in these points of Evidencing Justification by Sanctification the frequent urging the term of Works, and our own Works. (73-4)

Besides wanting Cotton, Hutchinson and their ilk to desist with the constant allegations that certain ministers are in fact "under the Covenant of Works," Cotton's inquisitors also employ the tautological reasoning of going "aside" to the covenant of works as being justified only when one is not doing so. The ministers' evident frustration with Cotton for seeking out their all-tooconsistent seeking is reflected in their "disrelishment." Cotton calls the ministers on their "empty tautologie" in his "Rejoynder" to their Question 13 response:

But when you say that to go aside to a Covenant of Works to seek to see the promised seed is a going aside to a Covenant of Works, it seemeth to me an empty tautology. To go aside to a Covenant of Works (for what end soever) is doubtless a going aside to a Covenant of Works.

He also returns the elders' snippiness, accusing them on multiple occasions of misrepresenting 
his answers and replacing his words with "pithie expressions." As he goes on, Cotton seems to want to further annoy the elders by using the term "works" as frequently as possible:

For if the Covenant of Grace do hold forth Justification and the Assurance of Justification not out of Works but out of Grace, and out of Grace not to works, but without works, to him that worketh not, then to make use of Works and of Grace to works to gather the Assurance of my Justification is not the way of the Covenant of Grace but of the Covenant of Works rather.

Putting the point on it, "If you therefore disrellish so much of the name of works ... then you must be entreated ... to disrellish the thing itself," following the lead of "Calvin and others our best Protestants" (132-3). ${ }^{93}$ Cotton effectually calls out his fellow New England ministers to acknowledge the uncomfortable reality that the covenant of works in fact defines, through negation, the covenant of grace.

Through all this "going aside"of sarcastic broadsides and typological innuendoes, a fundamental truth emerges concerning the concept of the covenant as played out in the formulations of covenant theology. Cotton is reacting to the implicit dangers, not of committing infidelity with the covenant of works, but of waking to the fact that there is no other covenant available in the covenant marketplace - to follow the typology, there is no Esther, only Hagar, and the ministers might as well provide assurance to their flocks by (falsely) teaching reliance on the covenant of grace while in reality smuggling in the "promised seed" of the covenant of works. ${ }^{94}$ As the ministers declare by way of a counterfactual: responding to Cotton's assertion

93 Cotton ends his Question 13 rejoinder — by far the longest of them all—with a nod to the "uncouth and strange" nature of their argument, which he says is due to the "perillous times" (142).

94 It is fitting that one of the 82 Antinomian "errors" refuted by the 1637 synod claimed that all "Covenants expressed in words" are under the Covenant of Works, to which he responds that this would incorporate all covenants, including the Covenant of Grace itself (D. D. Hall, Antinomian 239)! 
that a doubting soul must await God's "free promise of Grace,"

We say the same, if by a free promise you understand as well a conditional as an absolute promise. Which kind of promises if they be not free they should abolish rather than make parts of the Covenant of Grace. (74)

Cotton responds by, essentially, abolishing the conditions through Christ's simultaneous fulfillment: "For free they be, not because blessings are freely promised to such conditions (for so it is in a Covenant of Works) but because both the conditions are perfectly fulfilled in Christ" (137). The point of Christ's fulfillment of the conditions, both of the law and of the promise, is to make the promise a conditional assertion; the covenant of grace becomes purely conditional, purely of works, due to the work it must perform in abolishing the condition.

Thus, one can see Cotton's problem: doubt of justification (described as "lying prostrate" in Question $12^{95}$ ) cannot be solved through reenforcement of ("building on") sanctification, because the mystical union with Christ represented by justification is of a different order entirely, and permanently doubtful in the covenantal scheme. In other words, the covenant of grace, through fulfilling the covenant of works, works directly against justification. As Žižek would say, channeling Hegel and Lacan, justification is the negation of the negation of the covenantal dialectic, exposing the kernel or excremental remainder of doubt as the fundamental Real of election. The believer is, in a very real sense, predetermined by the covenant to be damned and saved simultaneously.

Turning now to the proceedings of Anne Hutchinson's examination by the Massachusetts

\footnotetext{
95 Intriguingly, Question 12 was originally printed to state: "Whether when my Sanctification lyeth prostrate, I may not prove my self in a state of Grace by my Sanctification?" Hall changed the first "Sanctification" to "Justification," correctly calling it "an obvious error"; nevertheless, allowing the tautology to stand would be more accurate, in that under Cotton's injunction Sanctification can only prove one's state of Grace by lying prostrate and removing itself from consideration.
} 
General Court in $1637,{ }^{96}$ which immediately precede her banishment from the colony, we see this excremental remainder in full display. Hutchinson's first response to her examiner is to question the examination itself, and whether she has committed any act (read, work) that breaks any law:

Mrs. Hutchinson. I am called here to answer before you but hear no things laid to my charge ... What have I said or done?

Gov[ernor Winthrop]. Why for your doings, this you did harbour and countenance those that are parties in this faction that you have heard of. (312) Hutchinson continues to ask throughout the trial the essential question, "What law have I broken?" (313) and to request clarifications of the rule of law that she was accused of breaking. In her constant requests for legal guidance, Hutchinson exposes the inherently theological problem at the heart of the entire controversy: If one is saved through grace, what is the status of the moral law? How can grace fit within the covenantal legal framework? The covenant of grace only "works" through its opposition to the covenant of works, which is inherently contradictory, and at the same time one and the same thing.

When Hutchinson begins to request not only clarification of her crime but also for the authorities "to put it down" in writing (316), and demands proof of their accusations, the magistrates become agitated:

Mrs. H. I pray Sir prove it that I said they preached nothing but a covenant of works.

Dep. Gov. Nothing but a covenant of works, why a Jesuit may preach truth sometimes.

\footnotetext{
${ }^{6}$ Taken from the "ancient manuscript" account included in Thomas Hutchinson's History of the Colony and Province of Massachusetts Bay (1767), rather than from Winthrop's A Short Story of the Rise, reign, and ruine of the Antinomians, Familists \& Libertines (1644), which was abridged and obviously biased in its presentation.
} 
Mrs. H. Did I ever say they preached a covenant of works then?

Dep. Gov. If they do not preach a covenant of grace clearly, then they preach a covenant of works.

Mrs. H. No Sir, one may preach a covenant of grace more clearly than another, so I said ...

D. Gov. When they do preach a covnant of works do they preach truth?

Mrs. H. Yes Sir, but when they preach a covnant of works for salvation, that is not truth.

D. Gov. I do but ask you this, when the ministers do preach a covenant of works do they preach a way of salvation?

Mrs. H. I did not come hither to answer to questions of that sort.

D. Gov. Because you will deny the thing.

Mrs. H. Ey, but that is to be proved first. (318)

Hutchinson is requiring the court to prove a negative, or rather a negation of a negative, in that the covenant of works is not the opposite of the covenant of grace but its own negation, its less "clear" other. To prove that she accused them of preaching the covenant of works is, exactly, tautological - they could preach nothing else, but it is up to them to prove it, an impossible request, akin to speaking directly to one's unconscious as opposed to allowing the unconscious to speak, or of freely electing oneself for salvation. Hutchinson is, in this way, speaking directly to the magistrates' unconscious, or rather, their unwillingness to listen to, to face, the unconscious (of the) covenant (of grace). ${ }^{97}$

\footnotetext{
97 One can see this same dynamic play out in the general discussion of the difference between speaking in private versus public (319) and Hutchinson's request for those accusing her to take an oath (327 passim).
} 
Thus, the purpose of Hutchinson's examination is precisely the opposite of what Shepard claims it to be:

Let men speak what they will not only against persons but against ministry, let that pass, but let us strive to speak to the consciences of men, knowing that if we had the truth with us we shall not need to approve our words by our practice and our ministry to the hearts of the people, and they should speak for us and therefore I have satisfied myself and the brethren with that. (323)

Shepard opposes the "conscience" of the examinee with the "truth" of the covenanted community. For the "truth" to be "with us," to be self-present, is equated with words being themselves self-present and not in need of approval through practice- a general equivalence of the "truth" of the spirit with the words (but not deeds) of the New England Puritans. The selfpresence of words comes to a stark turn in the examination when, at the beginning of the second day's testimony, Hutchinson abruptly requests that all witnesses against her testify under oath:

Mrs. H. The ministers come in their own cause. Now the Lord hath said that an oath is the end of all controversy; though there be a sufficient number of witnesses yet they are not according to the word, therefore I desire they may speak upon oath ...

Gov. For that which you alledge as an exception against the elders it is vain and untrue, for they are no prosecutors in this cause but are called to witness in the cause.

Mrs. H. But they are witnesses of their own cause.

Gov. It is not their cause but the cause of the whole country and they were 
unwilling that it should come forth, but that it was the glory and honour of God. Mrs. H. But it being the Lord's ordinance that an oath should be the end of all strife, therefore they are to deliver what they do upon oath.

Mr. Bradstreets. Mrs. Hutchinson, these are but circumstances and adjuncts to the cause, admit they should mistake you in your speeches you would make them to sin if you urge them to swear.

Mrs. H. That is not the thing. If they accuse me I desire it may be upon oath. Mr. Brown. ... If I mistake not an oath is of a high nature, and it is not to be taken but in a controversy, and for my part I am afraid of an oath and fear that we shall take God's name in vain, for we may take the witness of these men without an oath. (327)

The examination continues with the ministers variously being asked to give testimony under oath and them not seeming to be able (or willing) to do so, and the question of the necessity of testimony being offered under oath questioned, particularly by Winthrop and Shepard.

The whole impetus of the trial, from a theological vantage point (rather than the equally compelling view that they were merely trying to rid themselves of a troublesome woman), is defining the threshold between discourse and damnation governed by the proximity of the covenant of works. When Cotton begins his testimony at Hutchinson's examination, he backs up her statement that, even though she criticized the ministers' preaching, she never claimed they were under the covenant of works:

[S]he told them to this purpose that they did not hold forth a covenant of grace as I did, but wherein did we differ? why she said that they did not hold forth the seal 
of the spirit as he doth. Where is the difference there? say they, why saith she speaking to one or other of them, I know not to whom. You preach of the seal of the spirit upon a work and he upon free grace without a work or without respect to a work, he preaches the seal of the spirit upon free grace and you upon a work. I told her I was very sorry that she put comparisons between my ministry and their's, for she had said more than I could myself, and rather I had that she had put us in fellowship with them and not have made that discrepancy. She said, she found the difference ... And I must say that I did not find her saying they were under a covenant of works, nor that she said they did preach a covenant of works.

Given that he is testifying to the contents of a discussion that occurred nearly a year earlier, Cotton still shows remarkable (and perhaps suspicious) nonchalance with doctrinal fine points and theological distinctions that he had recently been arguing with the same elders that were in the room. Hutchinson's speech, publicly spoken in private and unable to be forsworn by the leading clerics, does indeed accomplish more than Cotton did in all his depositions, and does in fact disprove in the very act of denying proof the precepts of covenant theology.

In the end, perhaps seeing that nothing would come of the testimony but a messy conclusion, Hutchinson suddenly offers to "give you the ground of what I know to be true." She describes how, through a series of revelatory biblical passages, she came to understand that "those which did not teach the new covenant had the spirit of antichrist, and upon this he did discover the ministry unto me and ever since ... which was the clear ministry and which the wrong." What's more, she admits this knowledge to come from "immediate revelation," and 
provides her own account (or "relation") of how she determined Cotton to be a true minister and followed him to New England (336-7). The covenant's function as a negation of its own premises remains in force only if free grace has free reign through direct revelation. Hutchinson's claim of direct revelation is the only consistent response to the vagaries of the covenant-a prophetic gesture toward not only the history of the covenant in the hands of Edwards and Emerson, but also toward the coming battles between the resurgence and dominating Antinomian Pentacostals and the widespread but stolid Arminian Methodists. As Winthrop perceptively says later of Hutchinson's revelation of revelations, "It overthrows all" (343).

We can see the New England Puritan ministers gingerly step away from the Antinomian controversy in subsequent publications on the covenant, sticking most closely to discussions of the covenant of grace for personal salvation, neatly severing it from the covenant of works mostly through reference to its absolute versus conditional nature. Hooker, who appears to have attempted to stay out of the fray (though — and perhaps because — he is at least once mentioned as an Antinomian favorite), published a series of sermons, The Covenant of Grace Opened (1649) focused almost exclusively on proper and efficacious "seals," sacraments and ordinances, of the covenant.

It is left to Bulkeley in his full-length treatment, The Gospel-Covenant (1651), supplemented by works on the subject by Cotton, to establish the general agreement and consistency between the covenants of works and grace with the New England Puritans covenant theology. Instead of saying that there are no works in the covenant of grace, Bulkeley simply shifts the order of emphasis, preserving good works "for the persons sake":

[I]n the covenant of works Gods acceptation begins with the worke, and so goes 
on to the worker or person working; but in the covenant of grace, his acceptation begins with the person, and so goes on to the work; In the one God accepts the person for the workes sake: In the other God rewards the worke for the persons sake. (77)

Thus, Bulkeley is able to recharacterize the conventional idea that good works serve the ends of glorifying God's grace and rework the covenant of works as a byproduct of the covenant of grace, which at the same time — again, through a telling tautology_-becomes an identifier of the identity of the "ends" of God and His chosen ones, providing assurance "in some measure" of election:

Seeing Gods end in the Covenant of grace is to glorifie his grace in us, we may by this in some measure dicerne what part we have in the grace of this Covenant. And we may do it by this, if our ayms and Gods ayms, our ends and Gods ends meet in one, when we come to seek grace in his sight. (85)

This less confrontational, Manichean view of the covenants, while not wholly subscribed to by Cotton, is certainly not openly challenged in his own subsequent works on the subject. In Covenant of Gods Free Grace (1645), Cotton finds God "accepting" if not rewarding the believer's attempts at good works: "[I]n the Covenant of Grace, God rewards us not according to works, but according to his grace, accepting of our desires and indevours" (12). In his later and longer Covenant of Grace (1655), Cotton refocuses the distinction between works and grace based on God's unilateral provision, thus combining both conditionality and unconditional sovereignty:

$[\mathrm{H}]$ ere's the difference, in a Covenant of workes God giveth himselfe 
Conditionally; in that of grace, Absolutely; in both he maketh a Covenant, in the one of Grace, the other or works ... (42)

In general, these books are less laborious than Cotton's earlier detailed responses to the elders during the Antinomian controversy, and focus on ameliorating differences both in the theology and, one assumes, among his fellow New England ministers.

Hutchinson's contention and the resulting controversy and accusations and denials hide the fact that they are true - the Puritan ministers, Cotton included, were preaching the covenant of works, as they should have been doing. What the Antinomian controversy drives home, regardless of its dénouement, is the fact that the covenant of works is the covenant; the covenant of grace only makes sense through its postulation. Stoever, in an attempt to gloss what he calls the "dialectic" of covenant theology, makes an interesting and perhaps necessary elision between God and mankind:

Under the covenant of grace, obedience is performed for men by Christ, the resulting righteousness belonging personally to Christ and being imputed to men by God. The condition of this imputation, however, is a human act: namely, willing acceptance of the offer of Christ's righteousness, together with a vow of renewed obedience to the moral law. In this respect, the covenant of grace takes its form from the covenant of works, as a mutual transaction involving a willing act on man's part. (96)

The covenant of works, historically the last to be developed by covenant theologians, retroactively provides a transactional structure for the covenant of grace; likewise, God's covenantal scheme is infected with human conditionality through a reverse imputation. In this 
very Žižekian way, covenant theology enacts its own predestination through its ahistorical ideological construction, projecting conditionality—with all its political and libertarian implications — into the realm of divine grace.

In the final analysis, Antinomianism is not synonymous with human freedom; quite the opposite, it stands for the complete dependency of human will to divine decree. Grace demands only conformity; there is nothing an individual can do to influence it, and one's fate is completely determined by its pronouncement. The attempts by Cotton and those of his progeny, Increase and Cotton Mather, to restore the prospects of covenant theology into the eighteenth century, assisted in converting the covenant from a theological practice of forming churches to a liturgical device to maintain them. ${ }^{98}$ However, the fundamental contradictions inherent in the theology itself, as performed in the controversial early years of the settlement, were to reappear in later efforts to define broader metaphysical and political themes of freedom, liberty, and equality. After this last gasp of the outward political covenant as a necessary enactment of the divine covenant scheme was dashed by the political crisis of the 1680 s regarding the revocation of the colonial charter, it was left to later theologians and theoreticians to determine the future course of the politics of grace in America.

What we will see first in Edwards and then in Emerson is the playing out of this contradistinction within the concept of covenant between individual liberty-qua-equality and the freedom of predestination. God's position of freedom, as Žižek makes clear, pre-positions subjective humanity as the repository of freedom — an external "reflexive determination" of Godlike power. This happens only because the theology we have been studying positions the figure

98 Perry Miller's The New England Mind: From Colony to Province (1953), considered by many historians to be his masterpiece, details this transition. For an excellent alternative account of the waning of the covenantal tradition, see Foster 175 passim. 
of Christ as fulfilling the law (works) by fundamentally undermining it - the covenant of grace fulfills the covenant of works by abolishing it, which only makes it stronger. 


\section{CHAPTER 3: CONVERTING THE COVENANT}

[F]or freedom to take place ... it must already have taken place in

God as his incarnation.

Žižek, The Sublime Object of Ideology, 230

These gentlemen suppose that the thing wherein the will exercises liberty, is in its determining its own acts. But how can this be, if it ben't active in determining? Certainly the will, or the soul, can't exercise any liberty in that wherein it don't act, or wherein it don't exercise itself. So that if either part of this dilemma be taken, this scheme of liberty, consisting in self-determining power, is overthrown.

Jonathan Edwards, Freedom of Will, 176

Terrence: We're gonna make a covenant, Carl. Do you want to make a covenant?

Carl: Um ...

Terrence: The word is "yes," Carl.

Crowd: Yes!

Yes Man (2008) 
Jonathan Edwards is often represented as the last great American Puritan, a hold-over from the early Colonial theocracy while the rest of the country moved on to revolution, liberation, and modernity. Most scholars studying early America see him as much more than that. Perry Miller claims him to be our first great philosopher, an immense mind barely contained by a minuscule theology. My argument places Edwards somewhere in the middle of this theointellectual mix - a bulge, so to speak, in the history of a theocratic theology succumbing to its own overt demise, while at the same time marking the conversion of our unconscious political philosophy.

By Edwards' time, the Continental covenant theology implanted in America by its English settlers had taken a radical change in scope, as the pressure of church denominationalism both de-essentialized the theological status and ramped up the practical role of the covenant concept. In the late seventeenth century, Congregational church covenants went through a period of reconceptualizations and renewals, mostly through the able if arcane leadership of Increase Mather. Such renewals pushed the theological structure into the realm of political rhetoric and institutional solidarity in the face of the decommissioning of Congregational hegemony in external politics. Therefore, one could say the covenant as an institutional force became more determinative as it grew less influential. ${ }^{99}$

Edwards is best known for overseeing and legitimizing the early eighteenth-century

99 See Foster, Chapters 5-6, for the most comprehensive and approachable description of the "highly creative" period of institutional conflict from the mid-1650s to the mid-1680s, with its apex in the Halfway Synod of 1662, when the New England ministry refocused its efforts on a unified defense of the practice of establishing church covenants. One could say that the "Halfway Covenant" basically institutionalized into church polity a banal version of the covenant of works, in that children of church members could retain membership by "owning" the church's covenant, but could not participate in church ordinances until providing a "valid account of the work of saving grace" $(179,187)$. See also Pope's still unparalleled book-length study of the dreary Halfway Covenant controversy, and Holifield and Pettit for more detailed descriptions of the fate of the "purified" church covenant concept in relation to baptism and communion. However, for the sheer drama (or black comedy) of divine intellects during this period being stretched on the racks of their own belief, nothing beats Miller's New England Mind: From Colony to Province. 
"Great Awakening," a significant shift in Colonial spirituality. Most scholars of the period see covenant theology playing little to no role in the revival/awakening movement. What I hope to show is that, while the covenant concept became less of a touchstone in the theology of and surrounding Edwards, its complex structure can be read through his theological works, in particular Freedom of the Will, which effectively converts the covenant from its sixteenth- and seventeenth-century theocratic roots as the primary (if conflicted) arbiter of the Reformed Protestant theology of radical ("irresistible") grace into a structural motif for his central conflict against the idea of self-determined freedom. Thus, we will see Edwards re-engage with the difficulties John Cotton and Anne Hutchinson experienced in navigating between the covenants of works and grace in the Antinomian waters of early American Puritan conflict literature, this time at a more philosophical level and against the opposite current of Arminianism.

\section{Will in the World - Reading Edwards}

For a work that was drafted in only seven months while living on a frontier outpost, Edwards's A Careful and Strict Enquiry into the Modern Prevailing Notions of that Freedom of Will, Which is Supposed to be Essential to Moral Agency, Vertue and Vice, Reward and Punishment, Praise and Blame (1754), more than any of his other works, cemented his reputation as both America's greatest and its most controversial eighteenth-century author. I. Woodbridge Riley calls Freedom of the Will ${ }^{100}$ Edwards's "best known treatise" as well as his

${ }^{100}$ Freedom of the Will (1957) was the first published volume, under that title, in the recently completed Works of Jonathan Edwards series by Yale University, started under Miller's general editorship. Prior to this authorative edition, the work was commonly referenced by this title as well as by "Edwards on the Will." This publication marked "a turning point in the interpretation of the text" (Guelzo, "Freedom" 128); however, not too much should be read into the fact that Freedom of Will was the first volume published in the series, as Edwards's treatises did not require manuscript work (though there was quite a bit of unexpected effort regarding printer errors) (Crocco 158). Finally, it is important to note that Yale's publication is unique among collected writings by great religious thinkers in not being sponsored or controlled by a particular religious group or denomination-in 
"most laboured work" $(110,112)$, and W. P. Jeanes blames "twentieth-century philosophical prejudice" for the lack of regard for Freedom of Will, which should be considered "his most important piece of scholarship" (1). ${ }^{101}$ Miller elaborates that the work stands as "the cornerstone of Edwards' fame," "his most sustained intellectual achievement," and "the most powerful piece of sheer forensic argumentation in American literature." However, he also found that, due to its "sterile" style, Freedom of the Will was the "least valuable of his major productions ... for American literature," a mere "prologue" to his great "Rational Account" of Calvinist theology he barely started before his untimely death four years later in 1758 (Jonathan Edwards 251). Paul Ramsey, in his introduction to the authoritative edition of Freedom of the Will (1957), calls Edwards "the greatest philosopher-theologian yet to grace the American scene," and counters Miller that the work is indeed "Edwards' greatest literary achievement" which embodies the larger goal of all Edwards's major writings, in that the refutation of self-determinism sits at the center of his entire project. Indeed, Freedom of the Will stands as a "superdreadnaught" delivering "the most thoroughgoing and absolutely destructive criticism" of self-determination in existence, both then and now (1-2, 31-32). ${ }^{102}$ Thus, one can see why Allen Guelzo, the foremost authority on the work, finds that Freedom of Will "still suffers among Edwardsean interpreters in almost inverse proportion to its importance in the Edwardsean canon" ("Freedom" 128), generally considered a work of "genius" but of dubious literary or cultural value.

fact, begun by an avowed atheist (McClymond 361).

${ }^{101}$ Expanding on Jeanes's point, Roland Delattre finds that most late twentieth-century scholarship focuses on the validity of religious experience explored in Religious Affections (1746) and The Nature of True Virtue (1765), while early nineteenth-century writers were more interested in the theologically focused Life of David Brainerd (1749) and Freedom of Will. The latter, in particular, was "central to Edwardsean influence in those decades" but no longer considered as occupying "the formative center of Edwards's thought" ("Recent Scholarship" 369-70).

102 According to Ramsey, this over 200-year-old argument remains effectively unrefuted, and agrees with a nineteenth-century commentator that "There is no work of higher authority among those who deny the selfdetermining power of the will" $(10,12)$. Emphasis on which of Edward's works are most important to scholarship depends on current trends. 
This strong yet conflicted response to Freedom of the Will is not limited to Edwardsean scholars, but appears to have been the general reaction received by the book ever since its publication. The work was debated in print in the 1770s-90s at home and in the mid-nineteenth and -twentieth centuries abroad, including some rather detailed and analytical (even multivolume ${ }^{103}$ ) refutations, along with accusations of being "absurd," "founded in error and delusion," "essentially shallow and superficial," rambling, lacking "intellective conclusions," relying on "crincumism ${ }^{104} \ldots$ quibble and logomachy, and ... nonsense," and simply "irrelevant" (Lesser, Reference 41, 47, 65, 64, 181). Oliver Wendell Holmes observed that "Edwards's systems seem ... to the last degree barbaric, mechanical, materialist, pessimistic," and Mark Twain's summary judgment was that the book was an "insane debauch" written by "a resplendent intellect gone mad" (Noll, "Freedom" 98). Even Abraham Lincoln wished he had had time to read it (Guelzo, "Freedom" 127). Freedom of the Will seems to have had an extraordinary impact on major nineteenth-century writers, from Herman Melville to Harriet Beecher Stowe, ${ }^{105}$ and to have been considered both morally repugnant and logically "impregnable" (Edwards 1). Viewed from the end of the nineteenth century, Freedom of the Will was "one of the literary sensations of the last century" and, "to a large part of the religious world, a veritable shock, staggering alike to the reason and the moral sense" (Allen 90).

103 In 1782, the minister James Dana complained to Ezra Stiles, President of Yale, about the continued teaching of Freedom of Will, which "has been the root of bitterness which has troubled us like Achan in the camp of Israel" by promoting fatalism, "mechanism," "Deism, and atheism," and even blaming (fatalistically, one might add) a murder-suicide on Edwards's clearly "dangerous" book. Dana had already written a two-volume refutation of Freedom of Will, which Guelzo calls "the single longest piece of sustained philosophic invective in eighteenthcentury American literature" ("From Calvinist" 399-400).

104 "Crincumism" is an apparent neologism, not listed in the Oxford English Dictionary: probably meant as a derivative of "cringe."

105 Harriet Beecher Stowe claimed that Edwards "sawed the great dam and let out the whole waters of discussion over all New England, and that free discussion led to all the shades of opinion in modern days ... Little as he thought it, yet Waldo Emerson and Theodore Parker were the last results of the current set in motion by Jonathan Edwards" (Gura 153). 
So why this lurid, even abusive fascination with Edwards's Freedom of Will? One reason may be that its thesis comes across as outdated at the moment of its creation, a "cultural oxymoron" disconnected from its historical context:

It has been stood off by itself, like a Puritan doctrine bereft of any uses or applications, as though it were feared that the uses of such a work might be more ... than ordinary people could bear (Guelzo, Edwards 2). ${ }^{106}$

Another reason, related to the first, is that the force and importance of its argument stands in juxtaposition to its opaque analytical prose. It is not surprising, therefore, to find Freedom of the Will holding a troubled dual status, best summarized by Alexander Allen as "among the few great books in English theology" and deserving a "high place ... in literature," regardless of it being a "difficult one to read" (91). Though difficult, it was nevertheless read; in the century-and-a-half since its first publication, a new edition was published at least once every fifteen years (Knebel 129). Samuel Knapp included Freedom of the Will in his landmark Lectures on American Literature (1829)—-the first survey of its kind—calling it a challenging book whose "subject of inquiry ... commenced with the first man and will end only with the last; and will never be thoroughly explained by any one," yet acknowledging the significant national and international stature the book held among contemporary theologians and philosophers (qtd. in Gura 151).

Despite its notoriety, the book's theological argument was one that Edwards was fated to lose - as much as a theological argument can be lost in the court of public opinion —as antiCalvinists from the conservative evangelicals to the liberal Unitarians eventually came to

${ }^{106}$ Stephen Berk, by way of example, claims (inaccurately) that Freedom of Will comes out of "a remote, cloistered existence, out of touch with the strivings and yearnings of the average parishioner" and is directed "toward the small body of clergymen who composed the Armininan threat to experimental religion." The treatise is "entirely bound up in the concatenations of polemic divinity" and delivered a theological system "of moral, but not physical necessity" which in the end "involved only the intellect, distilling lifeless doctrine from prior, first hand awareness" (51-3). 
dominate the nineteenth-century theological conversation. ${ }^{107}$ Edwards's most influential public role, as a narrator and interpreter of the Great Awakening, was mostly accomplished through his best-selling Faithful Narrative of the Surprising Work of God (1737), which brought national and international attention to the religious revivals. ${ }^{108}$ Meanwhile, Edwards was personally and professionally swept up in a general crisis of clerical leadership resulting from the Great Awakening, while at the same time providing the intellectual foundation for a resurgent Calvinism in the form of the New Divinity movement which opposed the growing Universalist wave within Congregationalism (Schmotter 167). ${ }^{109}$ Still, Edwards's eighteenth-century reputation was limited, and publications were slim during and soon after his lifetime, only increasing in the early nineteenth century as the another "awakening" began to heat up (Gura 151). Elisa New calls the controversies surrounding Edwards's work "the second major American contretemps over the question of human control over spiritual destiny," the first being the Antinomian controversy of 1636-38, and the third the Unitarian controversy of the early

107 Mark Noll calls it "a mark of his spiritual profundity that Edwards so long influenced Americans who mostly thought that the logic of his Freedom of Will contradicted divine revelation" ("Freedom" 108).

108 Among the huge amount of scholarship on these phenomena, see Kidd for a detailed account of the transition "from Puritan to Evangelical."

${ }^{109}$ For an overview of Edwards's professional crisis in the context of his fellow clergy, see Harlan. For a full history of the impact of Edwards on the New England theology of the late-Eighteenth Century, see Guelzo, Edwards. Breitenbach provides a useful review focused on covenant theology. Of the three major late-eighteenth-century Congregational factions - the Liberals, Old Calvinists, and New Divinity - the Old Calvinists held to the Puritan covenant theology of the Westminster Assembly, mostly in reaction to the New Divinity movement. Eventually, by the early nineteenth century, their theological position became untenable and they were squeezed either toward the proto-Unitarian Liberals or the New Divinity theologians, the followers of Edwards. One could say that New England Puritanism resolved itself either toward Arminian-Unitarian or Calvinist-Edwardsian theology. For the latter, Freedom of the Will was the casebook for the New Divinity defense of Calvinism, while allowing flexibility and practicality into their doctrinal explications. For instance, New Divinity theologians were able to explain away the inequitable nature of limited atonement - Christ dying only for the Elect - by shifting from an economic model (Christ paying the debt of sin) to a governmental one (Christ atoning for everyone but requiring sinners to be punished for their crimes), thus making "salvation possible ... not ... necessary" in that Christ died for everyone but "only those granted sovereign grace could take advantage of the general offer." In so doing, "The New Divinity theologians liberated both God and man from the confinement of the covenant," in that grace was no longer "bound by the terms of a substitutionary contract," and each person "faced his God on his own" (Breitenbach 241 passim). 
nineteenth century, in which self-styled "pragmatic" theological forces ended up dominating. In New's estimation, "Edwards's campaign for the qualified power of the will was lost, one may hazard, for reasons both cultural and aesthetic":

It was probably Edwards's own intellectual sophistication that his party had to thank for its decline. The erudition of his arguments stranded orthodoxy on the sands of a scholasticism that liberals found increasingly easy to lampoon as pedantry and thus made Edwards his own most formidable opponent.

However, as New rightly points out, Edwards's argument is deeply rooted in the "philosophical qualification of the will by experience," to the point where he justifiably can be considered a major source of American pragmatism (384-5). ${ }^{110}$ My contention is that Edwards's failure is symptomatic of both his scholarship and theological heritage, in that Freedom of the Will functions as an explication of, and at the same time an argument against, the "failed" theology_a covenant theology based on the tautological identity of "grace" and "works"—-that, as Žižek succeeds in pointing out, becomes our field of political meaning.

Indeed, studies of this period have found that contemporary theologies appear more and more to be directly implicated in the resulting political upheaval of the American Revolution. In general terms, Thomas Kidd is right that "evangelicalism appears to have been born a roughly contemporaneous twin of that great phenomenon of the modern condition, nationalism" (296), and John Murrin's study of the relationship between the Great Awakening and the Revolution finds it commonly understood that an "extraordinarily high correlation exists between New

\footnotetext{
${ }_{110}$ New takes this opportunity to provide a backhand compliment to Miller who "brilliantly, though fallaciously, credited [Edwards] with paving Emerson's way." It is a curious trope in the scholarship on early America to praise Miller for his wonderfully executed errors. Another example: "Miller yet remains the most exciting strong reader in early American studies, his brilliant misprisions the occasion of many such bright, later misprisions" (D. B. Shea 274). I hope the reader views this study as another such misprision.
} 
Lights and patriots" (161). ${ }^{111}$ The incipient nationalism that fed the Revolution is almost indistinguishable from the "National Covenant" preached from Congregational, Presbyterian, and (less explicitly) other pulpits. Specifically, Alan Heimert calls Freedom of Will the "Calvinist handbook for the American Revolution," in that Edwards identifies liberty with moral ability (457-8). The counter-intuitive result, logically derived from Edwards's arguments, is that the defense of freedom of will, within the republican context, leads to less, not greater, political liberty (Guelzo, "From Calvinist" 418). ${ }^{112}$ Through his study of Edwards's detractors, Guelzo finds a "peculiar correlation" between Edwards's followers and the liberal republicans of the revolutionary era, in that

both the Edwardseans and the authors of The Federalist saw humankind as governed entirely by the perception of the greatest apparent good (whether in the form of "motives" or "interest") and carried along on their paths by passion (whether sacred or secular) in their response to that perception rather than by selfrestrained choices. (416)

We will see, in a closer review of Edwards's theology of grace and the covenant, that this alignment may be more complicated than it appears.

111 Interestingly, Murrin concludes that the Revolution would have happened without the Awakening, but may have not been successful, and would certainly have resulted in a very different nation/colony. That said, he finds the alignment more strategic than philosophical: "Jonathan Edwards can in no sense be regarded as the intellectual progenitor of Jefferson and Jackson. The very notion would have startled and dismayed all three gentlemen" (169).

112 Guelzo, in explaining this argument, points to the development of restrictions and regulations to protect freedom of choice ends up reducing one's range of choices, the result of "the paradoxical shape of that symmetry in American thought, which repeatedly casts fatalists and Calvinists in the role of emancipators, and casts freewillers and Arminians as anxious controllers." 


\section{Will and Grace - Edwards and the Covenant}

For being his most famous theological work, the importance of Freedom of Will to Edwards's overall theological project is still controversial. Miller highlighted Edwards's heavy engagement with contemporary philosophy, particularly that of John Locke, causing later readers to respond by emphasizing the book's "undisguised theological intentions, put in terms of a 'secular' argument" by "a theologian first and last and a philosopher only in between" (Guelzo, Edwards 2; Murphy 183). Nevertheless, Guelzo claims, Freedom of Will regularly receives short shrift by major twentieth-century reviews of Edwards's theology ("Freedom" 128). ${ }^{113}$ One reason for this may be Edwards's explicit engagement in Freedom of Will with "Arminianism," an early seventeenth-century branch of Reformed Protestantism defined by the followers of Arminius and against which Calvinists coalesced its own five fundamental principles: total depravity, unconditional election, limited atonement, irresistible grace, and perseverance of the saints. ${ }^{114}$ By the mid-eighteenth century, Noll finds Arminianism to be nothing more than "a catch-all word for moderately serious disagreements with traditional Calvinism" ("Freedom of the Will Abroad" 99). ${ }^{115}$ Another reason may be that the general popular distaste for Calvinism carried over to Edwards's work: Rem Edwards calls Freedom of Will "the best defense ever given to the worst theology ever conceived" (qtd. in Lesser, Annotated 40); many would no doubt agree.

E. Brooks Holifield, in his general review of Edwards's theology, centers him firmly in the Reformed Protestant tradition coming out of sixteenth-century Switzerland and southern Germany, yet blending in contemporary cultural, scientific, and philosophical themes to start his

113 The studies Guelzo cites as indicative of this trend are Cherry, Holbrook, and Delattre, Beauty.

114 For a detailed discussion, see the above introduction.

115 White provides a useful, even amusing history of the rise of Arminianism in England, simultaneous to the rise of "Puritanism," up to and through the Council of Dort in 1620 to the English Revolution. Ramsey observes that the original Remonstrance charter coming out of the Council of Dort was more "decisively theological" than "anthropological" and didn't specifically delve into "speculation upon the freedom of the will" (83). 
own "discrete Edwardsean theological tradition" that, depending on one's perspective, either saved or damned Calvinism in America ("Edwards" 144). Edwards's theology was based on three levels of religious knowledge: "light of nature," or natural theology; revealed knowledge, especially as seen through typology; ${ }^{116}$ and a "spiritual sense" of the biblical text. These three levels resolved themselves into an overall idea of "excellency," a comprehensive resolution of all forms of knowledge in God (146-7). Holifield finds that Edwards had a "lingering attraction to ... covenant theology," though it "no longer provided the guiding themes" for most of his writings, with the exception (as we shall see) of his Miscellanies (157).

Regarding the specific issue of liberty of the human will, Edwards's view is generally seen as "compatibilist," supporting the compatibility of liberty and necessity, freedom and determinism. However, Guelzo finds Edwards's compatibilism to be hierarchical, "in which necessity clearly played the dominant role and liberty served to explain necessity's operations" ("Freedom" 126). Sang Hyun Lee directly connects the "compatabilist" theological categorization of Edwards's views in Freedom of Will to his theology of grace, showing his attempts to resolve the ancient theological conflict between "uncreated grace" (gratia increata) as the sovereign indwelling of the Holy Spirit determining one's moral being and "created grace" (gratia creata) as the transformative impact of the Spirit's presence on the subject's moral acts (131).

For Miller, Edwards resolves this conflict by way of a strikingly modern, anti-Medieval naturalism: "The core of the Freedom of the Will is the assertion of the unitary and functional nature of the organism." This "radical naturalism," which Miller elsewhere calls a nascent

\footnotetext{
116 Typology, or the symbolic reading of biblical types, remains a focus of literary approaches to Edwards and early American religious literature; see Bercovitch, Typology and Brumm.
} 
empiricism, is opposed to the will being a faculty, separate from that of reason; instead, it is simply that bald, self-identical act of "man choosing" (Edwards 254-6). Lee, however, contends that Edwards "was actually more radically creative than Miller himself might have realized," in accomplishing "a thoroughgoing metaphysical reconstruction" of Christianity and a more fundamental assertion of "a strikingly modern conception of reality as a dynamic network of dispositional forces and habits" (Philosophical 3-4). This melding in Edwards's theology of Medieval theological categories with modern philosophical and scientific perspectives has led to Edwards being considered anything from a "Reformed orthodox" Calvinist, to an "actualist" seeker of reality, to a pragmatist espousing a "non-foundational logic of relations" (Delattre, "Recent" 370; Lang 378). Riley identifies behind Edwards's hard logic, largely derivative from Locke, "a vital connection with that profound belief of the immanence of the deity which was Edwards's earliest achievement." This connection can be found in Edwards's "double definition of the will" as the seat for both choice and desire, wherein he "superimposes the emotional upon the voluntary." Riley calls this "a fatal logical error" but one that "lay at the bottom of Edwards's peculiar personal experiences" and served as the foundation of his original metaphysics, his "doctrine of mystical insight through sensible knowledge" broaching through modern sensibilities into veritable pantheism (113-4). ${ }^{117}$

117 Stephen Daniel, in a rare use of post-structuralism to explain Reformed Protestant thinking, shows Edwards as employing an alternative anti-classical Renaissance mentality to oppose classical Medieval thought. Daniel's aim is "to indicate how contemporary work in poststructuralist and semiotic thought contributes to [a] re-examination of the limits of modernity by pointing to the alternative mentality on which Edwards draws" (200). In this "StoicRamist-Renaissance mentality," the world does not consist of things or substances that are the subjects of predication but rather of "communicative exchange and rhetorical action [which] form the basis upon which the distinction of subjects is made" (2). Similarly, R. C. De Prospo uses deconstructive arguments in his attempt to rescue Edwards's theism from Miller's romanticized connection to Emerson and the American humanistic tradition:

It is not only that Perry Miller distorts Edwards in arguing his continuity with Emerson; for Miller, the theism of Edwards' discourse was unperceivable, did not exist, so thoroughly was Miller a creature, ultimately, of Emerson's humanist discursive pattern. (qtd. in Shea 269)

Here we see again the alignment between theism and post-structuralism in their mutual suspicion of humanism, 
Edwards, of course, would find most of this speculative hogwash. As Ramsey rightly points out, for Edwards as a theologian the issue is a simple one: "[E]ither contingency and the liberty of self-determination must be run out of this world, or God will be shut out" (9). God's "irresistible" grace, as a divine truth revealed at the core of orthodox Calvinist dogma, is identical to that reflected by the inner self illuminated by special grace (Scheick 122). Nevertheless, this identity of inner (increatia) and outer (creatia) grace, of God's will manifested in mankind's willed acts, is an uneasy definitional structure to maintain outside of aesthetic categories such as his unifying view of God's "excellence." As such, Louis Mitchell finds that Edwards was forced to developed a theory of "theological aesthetics" based on correspondence and harmonization of disparate entities, from the exact correspondence of simple beauty to the proportional correspondence of complex beauty (37). Edwards's theory rested on God as the fountain of all that is beautiful leading to the necessity of the Trinity, in that complete simplicity or identity cannot be beautiful; beauty, instead, requires relationality, proportionality, consent. Thus, identity collapses beauty and, one might even say, theology; one must not be one with(in) God, but must instead have more than one god which is at the same time the One God. This correspondence directly embodies the relationship between the natural and spiritual worlds, in that the "agreement of equality and proportion in the natural world is a shadow of the agreement or consent of spiritual beings" (39-40), lending to the natural world what New calls the "ontological force" of beauty (382). ${ }^{118} \mathrm{New}$ goes on to restate Edwards's vision of the fullness of

for De Prospo's ultimate end creating a discontinuity between nature and grace. For our purposes in this study, one might say we are seeking to create not a continuity (Miller) or discontinuity, but an identity that troubles the very foundation of their supposed balanced relationship within the covenantal framework.

118 As Paul Helm puts it in his introduction to Edwards's Treatise on Grace, Edwards's insistence on the equality of the members of the godhead is ontological in reality yet covenantal in its communication:

God's determination to communicate Himself in the creation of the universe is prior to His determination to redeem. The natural equality of the members of the Trinity means that the subordination of the Son and the Holy Spirit must be covenantal not ontological in character. (14-5) 
creation as a determined yet excitingly saturated and comprehensive universe of infinite relations:

This is what Edwards means by grace: a divine creativity of such saturation and volume that providence is a principle of repleteness and surplus rather than stingy selection ... Unequivocally closing down any notion of untrammeled individual liberty, what Edwards's view of the will can offer in compensation is a metaphysics of greater fullness than one either driven by subjects or driven by objects, a metaphysics as sumptuous and replete as a physics, as thickly dimensional as an aesthetics. (388)

In simple terms, Edwards offers to his reader not just an argument against the self-determined liberty of the human will, but a comprehensive picture of a concomitantly God-centered and God-infused universe in which human liberty exists as yet another expression of divine will. Edwards applies all his profundity and mastery of complex philosophical, theological, and scientific arguments to defend what appeared to him as the obvious state of the world under God's grace.

Finally, Edwards's concept of grace, though expansive and exploratory, remained framed by covenant theology. Ironically, Edwards never wrote a major work on covenant theology, and a prevailing opinion among scholars, derived from Miller, claims that Edwards shunted the concept of a conditional covenant into oblivion. ${ }^{119}$ Stout finds general agreement among Miller and his detractors that Edwards "repudiated the 'national' covenant of his Puritan predecessors,"

119 For instance, Peter De Jong in The Covenant Idea in New England Theology (1945) claims that "beginning with Edwards the covenant idea, which was never too firmly grasped by the New England churches, was gradually forgotten" (136). Carl Bogue, in a more detailed study focused on the consistency of Edwards's Calvinism with Puritan covenant theology, finds "numerous references to the covenant of grace in the notes, sermons, and major treatises of Edwards" (302). 
resolving the "creative tension" of early Puritanism between the "contradictory covenants" of the public national covenant and the private covenant of grace by essentially taking sides with the latter. Stout, however, challenges this assumption and asserts that Edwards was "every bit the federal theologian that his Puritan predecessors were." Of course, in asserting this, Stout accepts the generally agreed upon definition of federal theology as the "creative tension" between the public and private covenants, emphasizing the former (143 passim). ${ }^{120}$

However, as many rightly point out, Edwards's rethinking of the covenant framework, though thoroughly orthodox, constitutes a reaffirmation and a re-emphasis of a number of "creative tensions." First, they point to Edwards's insistence that the very real tension that led to him being ousted from his Northampton church—and the shock that such an event had on Edwards as a Congregational minister cannot be overemphasized—was due to his opposition to Arminianism, an opposition most often expressed in terms of the covenant (Guelzo, "Freedom" 119-20; Chai 94). Edwards's use of the covenant motif in the Northampton controversy shows an emphasis away from the redemptive and toward the corporate covenant, at least for church membership. Edwards believed in "publicly owning the covenant" as a covenant "relation" separate from but related to the covenant of church membership. Edwards appealed to the covenant motif in attacking the "Arminian neonomianism" of allowing membership based on good behavior rather than profession of faith. As Conrad Cherry observes:

${ }^{120}$ Stout's essay, written in 1988 as a correction to Miller and his detractors, is still considered the foremost word on the topic of Edwards's relationship to his forebears and covenant theology. It was reprinted in 2005 with only minor revisions reflecting updated terminology—"federal theology" rather than "inherited covenant" (Hatch and Stout 157; Stout 288) - and available resources (references to new editions of sermons added to footnotes). Lee introduces the 2005 version by citing both the "recent attention" given to the relationship between Edwards and the Puritans and Miller's "almost unchallenged" view that Edwards threw over his forebears' covenant theology, suggesting that there has been little to no engagement on this issue for the past 30 years. Indeed, according to M. X. Lesser's comprehensive bibliography of Edwardsean scholarship, it appears that "covenant theology" was only actively discussed sporadically from Conrad Cherry's pioneering work in the 1960s to the early 1990s, with nothing since then (Reading 677). 
It is of utmost significance that the Puritan notion of covenant, which some suppose Edwards to have abandoned, should be appealed to by Edwards in the controversy that was most consequential for his life. Edwards sees a correlation between faith's covenant relation with God and the visible "owning" of that covenant in profession. (212-3)

Edwards was interested not just in the personal, individual covenant but also in the public, national covenant, ${ }^{121}$ one that functions as "the fundamental description of how Christians are related to God in faith." What's more, Edwards sought to refute the notion of an "external" and "internal" bilateral covenant popularized by his father-in-law, Solomon Stoddard, hearkening back to the early settlement of Antinomian debates over the covenants of grace and works, but more radically combining the two covenants into an identical calling. Edwards is most explicit on this point in his text, "Qualifications for Communion":

I know the distinction made by some, between the internal and external covenant; but, I hope, the divines that make this distinction, would not be understood, that there are really and properly "two" covenants of grace; but only that those who profess the one only covenant of grace, are of two sorts. There are those who

${ }^{121}$ Christopher Grasso, in a detailed study, emphasizes how the controversy that led to Edwards's expulsion from his Northampton church "reveals the ways that communal cohesiveness and corporate identity were rooted in public religious discourse," including his objection to "the rhetorical uses of flattering titles like 'God's Covenant People' for all nominally Christian New Englanders" in order to "accent the difference between nature and grace" against the "systematic equivocations at the heart of New England's system of interlocking covenants." "Owning the covenant" for Edwards required internal conversion and certainty, not just external agreement to terms (Stoddardites). Likewise, "profession" meant not just signaling agreement but taking a personal oath of compliance to its ordinances. Grasso points to Edwards's concern with and attempts to "correct the damage that common usage and tacit consent had done to terms like ... owning the covenant." However, Grasso fails to square the circle in pointing to the public nature of Edwards's insistence on the covenant as a profession of internal certainty - he requires an outing of one's inner election, which can only then be extrapolated to the national context. He states that "Edwards argued that outward covenanting must express an inward covenanting or it signifies nothing," but sees this as "separat[ing] what Stoddardean practice had joined" rather than offering a new (improved?) framework for a conflictual rather than a unified internal/external covenant (20 passim). 
comply with it "internally" and really, and others who do so only "externally," that is, in profession and visibility ... But it is with the "covenant," as it is with the call of the gospel: he that really complies with the "external" call has the "internal" call; So he that truly complies with the external proposal of God's covenant, as visible Christians profess to do, does indeed perform the inward condition of it. But the New Testament affords no more foundation for supposing two real and properly distinct covenants of grace, than it does to suppose two sorts of real Christians. (qtd. in Husband 246-7)

The "real" covenant of grace, for Edwards, is both external and internal, subsuming the covenant of works while still requiring its outward expression, not so much through good works but through the public "ownership" of one's outer life through one's inner light. As such, Edwards shifted away from Stoddardanism in emphasizing purity over covenantal continuity in the conflicts over church membership, but he did so through a unique use of what Paul Husband calls New England's "creative contribution" of covenantal dynamics in providing the balance between the inward and the outward, the spiritual and natural, grace and works (245-6). ${ }^{122}$ The most revealing premise of Edwards's argument in Freedom of Will, however, can be found in his Miscellanies, a running thought-journal he kept, indexed, and mined for material for

${ }^{122}$ Gerald McDermott, who has made a career connecting Edwards to the wider eighteenth-century public sphere, entrenches Edwards firmly in a "public theology" born from the Puritans' national covenant, as a forbear to American "civil religion" (see introduction), but without its optimistic flavor, instead inflicting "prophetic afflictions of the comfortable" through the jeremediac tradition (Holy Chapter 1,36). Edwards's understanding of the "national covenant" was the traditional one where "God entered into covenant with a nation, blessing or punishing that nation in proportion to its fidelity to the terms of the covenant." The national covenant is aligned with the covenant of works, in that it is opposed to the covenant of grace, which "concerned individuals" and "was based on faith" instead of the national covenant which "concerned nations" and "was based on works" ("Poverty" 242). This national, collective, political, and (at times) overly simplified version of the covenant of works may be described as an antipode to the covenant of grace, but it is at the same time directly connected through the covenant motif to salvation through God's sovereign grace. 
sermons and treatises throughout his life. ${ }^{123}$ One can see in these incidental texts how Edwards reconceptualized the covenant of grace as part of the divine reworking of the covenant of works through the office of the covenant of redemption. In so doing, he gave the "doctrine of the Covenant ... one of the most troublesome issues in New England thought ... its fullest, and finest, treatment" by making it both universal and personal (Davidson 37; Schafer 54-5). The Miscellanies provide a useful index of how important the concept of the covenant and its variations played on Edwards's thinking and theology. Out of 1,392 "Miscellany" entries made throughout his lifetime, 31 contain "Covenant" in their title, putting it right up there with "Faith" (39), "Grace" (47), "Justification" (53), and even "God" (105) as one of Edwards's major doctrinal considerations. Within the text of the Miscellanies, the term "covenant" is used 908 times. Of these instances, "covenant of grace" is specifically mentioned 169 times, followed closely by "covenant of works" at 140 , and "covenant of redemption" at $58 .{ }^{124}$ Contrary to assertions by Miller and others that Edwards emphasized the salvation by grace outside the covenant framework, the above evidence illustrates Edwards's abiding preoccupation with working out the various iterations of the covenant. ${ }^{125}$

Edwards takes pains to make explicit the difference between the covenants of works and grace, not just in terms of their nature (faith versus works) but also in terms of their parties,

123 When first contemplating the Yale Works of Jonathan Edwards series, Miller wrote in a letter that he considered "locked up" in Edwards's Miscellanies "the real Edwards, and that what we know from the published works is only the ruins of a magnificent system" (qtd. in Crocco 158).

124 This search, using the online "Miscellanies Index" of The Jonathan Edwards Center at Yale University, also included common cognates for the covenants of grace and works: "second covenant" and "new covenant" for the former, "first covenant" and "old covenant" for the latter. It should also be noted that the covenant of redemption, though mentioned with less frequency, commanded the longest Miscellany on the covenant (1062), which seeks to work out how the divine covenant relates to the "economy" of the Trinity.

125 James Carse claims that Edwards adopted the covenant "scheme" from early Reformed Protestantism "without any important changes"; however, he only has "scant" references to the covenant of works, relying instead on the relationship between the covenants of redemption and grace (91). Contrary to this assertion, in the Miscellanies the covenant of works is referenced a comparable number of times to the covenant of grace and more often than the covenant of redemption. 
which alters the entire form of each covenant. ${ }^{126}$ From the very beginning, Edwards finds "many difficulties" with the covenantal structure and its unavoidable yet troublesome distinctions between grace and works. In Miscellany 2, he can see "no difference between the condition of the first covenant and the second," in that the second simply limits the precondition for salvation on one virtue, faith, rather than on several, one's various good works. "For where is the difference?" Edwards asks, "the second is as much a covenant of works as the first." Edwards solves this problem by pointing to the true distinction, that being between the covenant of works and the covenant of redemption, which incorporates the covenant of grace. This he clarifies in Miscellany 30:

But if we speak of the covenant God has made with man stating the condition of eternal life, God never made but one with man to wit, the covenant of works; which never yet was abrogated, but is a covenant stands in full force to all eternity without the failing of one tittle. The covenant of grace is not another covenant made with man upon the abrogation of this, but a covenant made with Christ to fulfill it.

In other words, the covenant of grace is not a covenant between God and man but rather the operative function of the covenant between God and Christ, who stands in for humanity through a completely separate covenant of redemption among the Trinity.

Thus, there are in fact not two covenants, new and old, but one covenant differently iterated: "There have never been two covenants, in strictness of speech, but only two ways constituted of performing of this covenant" (Miscellany 35). According to Edwards, the first

126 The relationship of the covenants of works and grace, specifically in light of the doctrine of justification, is also discussed in the "Controversies" Notebook, with specific references to the Miscellanies discussed here; see Writings (354-368). 
covenant of redemption is between God and Christ as the federated public person representing humanity, which fulfills the covenant of works between God and mankind; the second covenant of grace between Christ and mankind relies on individual faith in the promise of Christ's fulfillment of the covenant of works. In this scheme, both covenants can be considered reciprocal, but in different ways: the former, as a political, collective covenant through a corporate head; the latter through a direct personal relationship that Edwards consistently compares to a marriage covenant (Miscellanies 617, 825, 919, 1091). Thus, one can see a sort of anachronistic evolution of the covenant of works, as a genus, into two species, the covenants of redemption and grace, all tracked back to and in direct genetic filiation with the original "deal"— one that, as we will see, appears in a similar anachronistic fashion in Freedom of Will.

The result of this covenant evolution is a lot of stray genes in the gene pool. In some of the Miscellanies Edwards takes pains to make explicit distinctions between the covenants of redemption (works) and grace, pointing out that, while the duties and law are the same, the mode of fulfilling those duties is "exceedingly diverse," in that "perfection is insisted on in the former covenant, and only sincerity in the other," and that (importantly for Freedom of the Will) "those things that are promises in one of these covenants, are conditions in another" — in other words, effects in one covenant become causes in the other (Miscellanies 825, 1030, 617). However, elsewhere Edwards is equally emphatic in tying all the covenants together through the representative treaty structure, making "consent to a covenant ... necessary to the very being in that covenant; a man can't be in any covenant till he consents to it" (Miscellanies 1091, 299). In the covenant of redemption, it gets even more complicated, as the relationship within the godhead must function as a "dependence without inferiority," and the "economy of the persons of 
the Trinity" in their mutually equal yet hierarchical relationship must be seen as existing prior to yet perfectly fitting with their various covenantal roles (Miscellany 1062).

We can see in Edwards's private struggle with the Reformed Protestant puzzle of the covenants not only a lack of resolution and a repetition of the covenant conflicts of the prior century, but also the generation of new covenantal themes which we will see play out in

Freedom of Will. The covenantal framework, in Edwards's hands, is converted from a question of polity, church and national membership, to one of relations between men, men and God, and members of the godhead. Additionally, covenants now not only exist in contradistinction to each other but, more appropriately, within each other, as covenants within covenants, tautological identities within and among ourselves. In this way, and mediated by what Žižek emphasizes as the "human divinity" of Christ as being non-identical to his own divine status, an impossible equality emerges between God and man, which in turn creates the opportunity (equally impossible?) for equality among humanity through the very split between the divine and the human as intrinsic to the human, an inherent inequality to/in ourselves which we all share.

\section{Grace Means Works - Reading Freedom of Will}

In turning from Edwards's private attempts to resolve the irresolvable theology of the covenant to his public denunciation of Arminianism, I will seek to show how Edwards in Freedom of the Will works out the political consequences of grace in Reformed theology by converting the covenant as a conflictual theoretical structure through his very opposition to its consequences. This is not to say, along with Miller, that the covenant undercuts the radical predestinarian nature of grace - a position which as we have seen has been forcefully challenged 
in subsequent historical and religious criticism. Rather, the concept of the covenant is a necessary working out of grace, best expressed in the contradictions inherent in the arguments Edwards spends so much time refuting in Freedom of the Will. Similar to Anne Hutchinson, Edwards is able to demonstrate the absurd arguments of the prevailing orthodoxy, while at the same time unconsciously demonstrating the necessity of their very absurdity.

Edwards's argument, which appears at first glance to rely primarily on the identification of action and will, is in fact one of the best formulations of the "covenant formulary" (Baltzer) of works and grace following its interplay in the early New England antinomian conflict. The "exercise of liberty" requires an act, and an act must by definition be determined by the will, so it is impossible for there to be an undetermined "free" act determining the will without the will itself being involved. And if the act of the will determining its own actions is held to be nonsensical, then one is only left with a pre-determination by an external will-hence Calvinist predestination as the logical supplement to naïve human liberty. ${ }^{127}$ Edwards stands as a bulwark at the beginning of the American notion of personal and political freedom, and calls it a fault of logic. Likewise, the covenant of works functions as the empty set that determines this illogical system to function, to "work" quite well on its own illogic. As Hutchinson demonstrated over a century before, the politics of grace simply do not work except as the covenant of works.

127 That said, Edwards was equally adamant in expressing his opposition to naïve or mechanistic determinism: I would say, that notwithstanding this doctrine, man is entirely, perfectly and unspeakably different from a mere machine, in that he has reason and understanding, and has a faculty of will, and so is capable of volition and choice; and in that, his will is guided by the dictates or views of his understanding; and in that his external actions and behavior, and in many respect also his thoughts, and the exercises of his mind, are subject to his will; so that he has liberty to act according to his choice, and do what he pleases; and by means of these things, is capable of moral habits and moral acts, such inclinations and actions as according to the common sense of mankind, are worthy of praise, esteem, love and reward; or on the contrary, of disesteem, detestation, indignation and punishment. (370)

There is a running debate over whether Edwards in fact leaves room for some form of freedom of choice in the form of "volition." Ramsey claims that "there is nothing in Edwards' account of an act of free, responsible volition which precludes it from being independent and self-moved" (25), while Murphy joins Edwards in calling such a claim "an absurdity" (191). 
While the term "covenant" is rarely used and never discussed theologically in Freedom of the Will, as it was in the Miscellanies, my argument is that its conceptual framework is key to reading the text, and vice versa. The term "covenant" only appears in Part 3, Section 2 as part of the exposition of biblical promises to mankind, emphasizing their permanence and impossibility of failure. The covenant or promise Edwards finds in Isaiah makes necessary and determinative God's eventually "establishing his kingdom of grace" (282), grace being here the historically and politically irresistible and determinative law in the form of a promise. In this way, the covenant of grace in Edwards's hands takes on the exact structure of the covenant of works in its determinative framework: the wages of sin are death. The covenant of grace does not replace works so much as double down on its strictures, here God's works necessarily (and, in the ahistorical scheme of God's promises, always already) replacing mankind's. One cannot help but sin; one cannot help but be saved.

Definition of terms takes up a considerable portion of the first half of Freedom of the Will and make up the heart of Edwards's argument (Ramsey 12). ${ }^{128}$ Edwards makes clear from the very beginning that "Freedom of Will" is a redundancy, as a will by its very nature is free. The question is whether a human being as a moral agent is free to determine one's own willed actions. At the same time, in the Preface, Edwards calls the will the seat of "all virtue and religion," which is itself "the great business for which we are created, and on which our happiness depends," so as to make it a very important topic that "demands the attention of Christians" (133). The will is later defined, in simple terms, as "that by which the mind chooses anything," or the human faculty of choice (137). This he directly ties to one's preference- - "a man's doing as he

${ }^{128}$ Ramsey finds that many of Edwards's refutations are "largely verbal" (77), and Miller found the book's "opening sections" to be of "principal interest for the student either of Edwards or of modern thought," as opposed to the following "lengthy demolition of feeble arguments" (251). 
wills, and doing as he pleases, are the same thing" — as well as to desire — "A man never, in any instance, wills anything contrary to his desires, or desires anything contrary to his will" (139). Even if the will is contrary to itself and its own object—-"The will may not agree with the will, nor desire agree with desire, in different things" — in the end, the will is comprehensively equal to and identical with its preference, pleasure, or desire, while at the same time utterly partial to its preference/pleasure/desire in its choice or volition (140). The will's extant partiality is determined by its strongest motive, which is perceived by the will as good. However, the will's perception is, once again, one and the same with itself, so that "the will always is as the greatest apparent good is." Wherever a strong motive originates, once it is perceived by the will as the greatest apparent good, it is subsumed in and becomes one with the will, so that there is no longer, if there ever was, any distinction. Likewise, in a very precise way, the will enters the causal analysis as both the effect of the strong motive and the cause of a voluntary action (1414). ${ }^{129}$

Even though the argument so far follows a causal chain, Edwards points out that the basis for his argument is definitional rather than causal:

I have rather chosen to express myself thus, that the will always $i s$ as the greatest apparent good, or as what appears most agreeable, is, than to say that the will is determined by the greatest apparent good, or by what seems most agreeable; because an appearing most agreeable or pleasing to the mind, and the mind's preferring and choosing, seem hardly to be properly and perfectly distinct. (144, his emphases)

129 What's more, motive must be something perceived or understood by the mind —in other words, Edwards's definitional system allows for no such thing as the unconscious, at least in regard to the motive which predetermines the will. We are, by definition, outside Žižek's conceptual realm of an unconscious covenant, as described in Chapter 1. 
"Appearing most agreeable" and "preferring or choosing" are to Edwards the same thingsimilar to the theological aesthetics of the godhead as both equal and relational at the same time and prior to the covenant of redemption. The "strength" or greatness of a motive determines whether it will determine the will to act. Thus, "good" is then, by definition, itself predetermined not so much by God but by the strongest of motives; if a motive is strongest among a given set, it will by definition be considered by the willing agent as good. One cannot, in effect, help but be good, simply because one cannot help but be motivated. If it were otherwise, we would be left with an "absurd" redundancy of having to determine (or "elect") a "good" outside of one's existing motivation to do so. Where would such a decision come from except through the predetermined motivation? It is a straightforward and, as set up by Edwards, an unbreakable and insurmountable challenge to the indifferent freedom of the will—while at the same time creating in its very counterargument the possibility, the "logic" if you will, of Žižek's formulation of a subject predestining itself through "an unconscious primordial act of decision" (Indivisible Remainder 18).

In his very definition of will as the faculty of choice, of choosing one thing/action/idea over another, Edwards exposes a contradiction within the definition, when he attempts to dissect Locke's distinction between will and desire. Edwards specifically excludes any distinction-"A man never, in any instance, wills anything contrary to his desires, or desires anything contrary to his will" (139) —yet forces himself to admit to both will and desire being capable to run counter to themselves, even while making their own terminological identity: "The will may not agree with the will, nor desire agree with desire, in different things" (140). Thus, though will and desire are identical to each other, they hold the possibility to not be identical to themselves; will must 
be equal to desire, but will may not be equal to will.

Still, this identity of the will and its pleasure or perceived good contradicts any notion of self-contradiction in the will. ${ }^{130}$ If it be agreeable to do it, one's will will choose to do so:

There is scarcely a plainer and more universal dictate of the sense and experience of mankind, than that, when men act voluntarily, and do what they please, then they do what suits them best, or what is most agreeable to them. To say, that they do what they please, or what pleases them, but yet don't do what is agreeable to them, is the same thing as to say, they do what they please, but don't act their pleasure; and that is to say, that they do what they please, and yet don't do what they please. (147-8)

This identification of will and action is key to understanding Edwards's argument, and the identity dynamics at play here are symptomatic of the same definitional and relational issues in the covenantal grace/works paradigm. For the will to work, choice is not the cause of action, but the action itself, which rests within the very preference/cause to act. This is exactly the way the covenant of works is structured: it is the identical to the covenant of grace, which functions within the covenant of work's virtuous framework (obedience to God) while at the same time creating a mystical superstructure (God's sacrifice fulfilling his own commandments) that waylays the need to act altogether; one fulfills the covenant (of works) by letting God do all the work.

One can see that, by the end of the first section of Freedom of the Will, Edwards had "maneuvered the terminology in such a way as to disarm the Arminians even before the battle

${ }^{130}$ Edwards's views appear to be a direct rejoinder to none other than St. Paul, who in Romans 7:19 admits, "I do not do the good I want, but the evil I do not want is what I do," as well as to St. Augustine's similarly unwilled bad behavior in the Confessions. However, Ramsey finds these differences "in large measure verbal," in that these are expressions of pre-willed behavior (50). 
was joined" (Guelzo, "Freedom" 123). Edwards then proceeds to elucidate the contradictions and absurdities in his opponents' arguments, denouncing his opponents' points as "contradictions," "gross absurdities," "ambiguous," and leading to nowhere, to non-existence, to driving God and good behavior "out of the world," as opposed to his own "common sense" arguments based on "natural notions of mankind." ${ }^{131}$ Edwards saves his choicest invectives for the idea of indifference being the necessary precursor for free choice. In fact, Edwards argues, indifference and liberty are irresolutely antithetical, to the point that "one excludes and destroys the other," and makes freedom non-identical to itself, so that it "can denominate nothing free, at the first moment of preference or preponderation"—-becoming something other than its indifferent selfwhich is "the highest degree absurd and contradictory." Furthermore, indifference can only suspend action, not effect it, so that its only ability to act would be to suspend its own suspension, so that "even suspension itself may be deferred: which is absurd." The ultimate result is to drive "the exercise of freedom back in infinitum; and that is to drive it out of the world" (207-211). In other words, it is when one is "out of the world" and truly indifferent that one can exercise true freedom, but only by perpetually suspending or deferring one's ability to act.

One can track Edwards's use of pejoratives and tautological arguments to establish his critique as well as his reconstruction of covenantal metaphysics. Edwards identifies at the core of Arminian principles of self-determination and equality before God an alternate destination of the nullification of Reformed Protestant metaphysics as a practical (or consistent) theology: "[T]he

131 Citations are legion, but here's a sampling of Edwards's invectives against his opponents: "absurd" and cognates (his favorite, 75 occurrences in the text, including cognates, 131 passim), "contradiction" (second favorite, 67 occurrences in the text, including cognates, 143 passim), "manifest inconsistence" (171), "repugnant" (174), "words without meaning" (179), "their notion destroys itself" (191), "highest degree absurd and contradictory" (208), "grossest nonsense" (210), "full of nothing but absurdity and self-contradiction" (212), "heap of contradictions" (235), "whole heap of inconsistencies" (238), "gross absurdity" (312), "an absolute nonentity" (my favorite, 345), "ridiculous" (390), "absurdity and nonsense" (391). 
principles are such as cannot be acted upon at all, or in any respect, consistently" (370).

However, Edwards is at the same time constantly challenging the commonplace alignment between works/natural/common sense and grace/moral/metaphysics, and we find in Freedom of Will how these opposites function as sides of a Möbius strip, similar to Žižek's "short circuits," constantly turning one into the other, as covenant circulates between the natural and moral realms. Edwards's identification of inconsistency and self-contradiction at the heart of Arminian doctrine, or rather at the heart of the Arminian take (double-take?) of the Calvinist doctrine, directly connects with the Reformed double-covenant of grace and works.

With similar forceful language, Edwards challenges the basis for self-determination in the fact that one can be faced with two "perfectly equal" options to which one is "altogether indifferent" and still make a choice. ${ }^{132}$ Once again, definition and false identification intrudes: a mind making a choice is no longer, by definition, indifferent; a mind cannot have "a preference, at the same time that it has no preference." The result is that the indifference is only dispelled after the choice is made, "that the chosen thing's appearing preferable and more agreeable than another, arises from its choice already made" (196). As a result, "a man chooses without choice" (198), and in like manner achieves freedom without the freedom of being indifferent prior to that original choice. And, as the choice is subsequent to the impossible a priori indifference to two equal options, one can say that Edwards's scheme also achieves inequality as the necessary result of equality. Thus, we find that Edwards's refutation of the inherent contradiction in the Arminian argument that allows choice without choice and freedom without freedom, also requires that

\footnotetext{
132 One might find this situation similar to Yogi Berra's humorous gambit that, when faced with a fork in the road, he "takes it," or Robert Frost's more poetic problem of two paths in the wood. What Frost and Berra (and, obliquely, Edwards) demonstrate, of course, is the third choice, choosing indifference, or enforced indifference that is no longer a choice. One can be forced to choose no choice, to be Edwards's "efficient Nothing" (184), confined to a freedom without options or opportunities, the ultimate Romantic bogeyman of pure equality.
} 
inequality (difference) be generated out of equality (indifference):

The objects may appear equal, and the mind may never properly make any choice between them: but the next act of the will being about the external actions to be performed, taking, touching, etc., these may not appear equal, and one action may properly be chosen before another. (201)

Objects may be equal to the mind, but its own action appurtenant to these objects can never be equal. This is, in fact, how freedom works in the Arminian context, directly as a result of the Calvinism that Edwards is attempting to defend: "... his own words are as much against him, and do as much contradict him, as the words of those he disputes against can do" (198). Arminianism, in Edwards's hands, becomes not the antipode of Calvinism but its very source, a name for a fundamental internal contradiction that makes the whole theology function - the conflictual "work" at the heart of grace. Indeed, Edwards, through his tautological definitions, appears to give God's grace unequal status, or rather to make grace equal to its own identity with what is good, which is the same as making it unequal in its very identity with one's very will and identity. Thus, in a significant way, grace stands unequal to equality, or beyond it. If identity is being one with or equal to oneself $(1=1)$, grace is being unequal to and more than oneself $(1>1)$. This unequal grace, in turn, becomes the basis for one's equal standing with others and with God -as long, that is, as one gives oneself freely and reflexively to a predestined status not one's own.

Edwards ends the treatise with an analysis of infinite inequality and un-likeness (lack of identity) to support actual instead of virtual predestination and efficacious grace (for some, not all—hence inequality). Edwards's critique is one that, in a reversal of the Council of Dort, results 
in defining the terms of modern inequality through the logic of the covenant. In the end, "will" relies on difference/inequality; a willed choice (redundantly considered) must be predetermined by a preexisting preference, "some preponderance of the mind or inclination, one way rather than another ... there, where there is absolutely no preferring or choosing, but a perfect continuing equilibrium, there is no volition" (140). ${ }^{133}$

Posing this contradictory "retroactive-ability" — to create a preference before the very act of preferring — brings us back to Edwards's causal argument with a vengeance. The contradiction Edwards points to again and again is the problem of freedom in a causal-moral universe; one cause or act must lead to the next, and the first cause can't come from nothing. ${ }^{134}$ More important than its derivation from First Cause theogenic arguments, however, is the radical notion of freedom introduced by Edwards in his supposition of the opponent argument: $[I] t$ supposes an act of the will preceding the first act in the whole train, directing and determining the rest; or a free act of the will, before the first free act of the will ... but if the first act ... be not free, none of them all can be free (177, my emphasis)

In order for the will to be free through self-determination, the will requires "a free act $\ldots$ before the first free act," a determination defining itself by its own freedom. ${ }^{135}$ In other words, freedom

133 Edwards provides further support for what may be called his "what is, is" argument for volition not being able to determine itself:

[I]nasmuch as volition can have no opportunity to determine whether it shall exist or no, it having existence already before volition has opportunity to determine anything. It is itself the very rise and existence of volition. But a thing, after it exists, has no opportunity to determine as to its own existence; it is too late for that. (222)

134 Edwards defines "cause" as any natural or moral "antecedent" that connects to or is responsible for the existence of any resulting thing, event, or circumstance. It is simply the law of being - "nothing ever comes to pass without a cause"-except for what is "self-existent," eternal, and "unchangeable" (180-1). Riley finds Edwards's definition of cause in Freedom of the Will ambiguous, as it does not resolve whether all moral causes are to be treated as occasional, efficient, or both (109-10).

135 Leon Chai claims that Edwards's argument of the "infinite regress" of causation is in conflict with his identification of will and choice as one and the same, what Chai calls Edwards's "principle of logical 
is retroactively determined by a free act that cancels or erases itself from the very beginning-a self erasure almost more Derridean than Žižekian, except for its determinative, effective, materialist rather than perpetually imminent force. ${ }^{136}$ Thus, radical "free grace" as a conceptand that is the overarching structure Edwards here describes - both creates (or is created from) and destroys freedom in one move. One could say that grace is the antimatter of (or what is the matter with) freedom. The concept of self-determining freedom of will in the face of grace, as defined in the covenantal Reformed tradition within which Edwards is working, contradicts itself (as it always had done) both necessarily and productively. This would make the covenant of grace inherently a contradiction with results - it works, even though it defies determinative comprehension. ${ }^{137}$

Which brings us back to the overarching yet invisible covenant of works, directly related to Edwards's most famous definitional move, the simultaneous identity and differentiation between natural and moral necessity. Like Winthrop in his Charitie sermon, Edwards seeks to make a clear distinction between the natural and moral universes, and seeks to situate his argument in the moral, not the natural, realm, but with the goal to defend virtuous action. He does this primarily through a formal distinction between moral and natural necessity, which

substitution." For infinite regress to function, like can no longer be like but must necessarily follow a series of subsequent (and unlike) actions (98). It appears, at first, that Chai is simply making Edwards's argument for him, in pointing to the problem of identification and causation being coterminous; thus causation wins out, and one's will is no longer able to will itself. However, there is also a necessity in there being different "sorts" of causes, first causes and causes that double as effects (all the rest). What we have here is a near identity that is mimicking an actual identity, or a near-equality —one that might as well be an inequality for the difference between God and man - making itself seem like an equality.

136 George Mavrodes, in one of the most intriguing readings of Freedom of the Will, claims that the text proves, contrary to Edwards's assertions, that God's infallible foreknowledge of events does not necessarily mean that those events are predestined to occur, in that God's foreknowledge occurs in the past, and as such is prone to seeing subjunctive, if equally infallible, alternative futures: "For the past consists not only of the things which have happened, but also those which have not" (141 passim).

137 A useful analogue of a similar theoretical and contradictory phenomenon with real results is the recent report on new "quantum" computers being built, using alternate universes we cannot yet see to make near-impossible calculations (Galchen). 
Edwards says "does not lie so much in the nature of the connection, as in the two terms connected" (158). Ramsey is right to call out the fact that, indeed, "the difference may be said to consist wholly in the terms connected and not at all in the nature of the connection" (38). Edwards's opponents claim that the distinction Edwards makes between natural and moral necessity, which is crucial to his argument, falls flat, as "the coercion is the same in both" (Adams 327-8).

However, Edwards takes pains to differentiate natural and moral necessity, in that the former can operate against the will whereas the latter is within and even identical to the will. For Edwards, works in the natural sphere are actually passive, as opposed to the active attributes of spiritual or moral grace. He defines "natural" agency as the capability of moral agency, whereas "moral" agency is the performance of moral acts (166). While both involve the will, only one operates as the will, and thus is by definition free to choose as it wills. In other words, the will acts differently and even directly contrary to nature, in that it is inherently and morally determinative while at the same time utterly free, while nature is inherently and morally indeterminative and prone to compulsion (360-1). So when Edwards claims that "necessity is not inconsistent with liberty," he means philosophical or moral necessity, not physical necessity (152). Moral necessity rides on the smooth theoretical plain of meaning, where subjects determine predicates without any opposition, as opposed to natural necessity which by the physical inference of inertia assumes an overcoming of resistance. Thus, one's moral act can be at one and the same time free, in that motives and actions like subjects and predicates are free from impediment in their determinative structure, and necessary (158-9). Also, moral acts are one and the same, and one cannot help but act as one wills; "the very willing is the doing; when 
once he has willed, the thing is performed; and nothing else remains to be done" (162). The result is a direct and necessary difference and yet causal connection between the function of grace through the will and one's actions (works) in the natural world. ${ }^{138}$

According to Edwards, the doctrine of necessity, which supposes a necessary connection of all events, on some antecedent ground and reason of their existence, is the only medium we have to prove the being of God, versus the doctrine of contingency, which "overthrows all connection, in every degree, between endeavor and event, means and end" (420-1). Indeed, for Edwards, "no event whatsoever is contingent" (216). However, this distinction between moral and natural necessity leads to its own contingency in the very causal-relational structure. One of Edwards's problems in straightening out misunderstandings about freedom of will and God's foreknowledge of moral events and acts of volition is the slippage between the "moral" and "natural" worlds, as demonstrated through an interesting series of errata in Edwards's original text. The following sentence is reproduced here as published in the first edition of Freedom of the Will:

For the moral world is the end of the natural world; and the course of things in the former, is undoubtedly subordinate to God's designs with respect to the latter. (251, my emphases)

Jonathan Edwards, Jr., in editing his father's work, reversed "former" and "latter," assuming his father would never subordinate the moral world to the natural. However, logically formulated, the moral world being "the [teleological] end of the natural world" would in fact subordinate the

\footnotetext{
138 Ramsey points out that the distinction between natural and moral necessity goes back all the way in Western metaphysics, and even suggests that "in the history of western ideas secular scientific and philosophical notions of causation and determinism are rooted in theological determinism" (42). Knebel makes the fascinating suggestion that Edwards might have derived his key idea of moral necessity as a basis for his compatibilism not from English philosophers but from Spanish Jesuits.
} 
moral effect to the natural cause, even as the natural cause could only be understood teleologically as the necessary route to the moral end or effect. This leads directly, in the next sentence, to a transformation in the usage of the word "cause":

Therefore [God] has seen cause, from regard to the state of things in the moral world, extraordinarily to interpose, to interrupt and lay an arrest on the course of things in the natural world; and even in the greater wheels of its motion; even so as to stop the sun in its course.

In order to see his moral end through, God sees "cause" to "effect" that end actively in the natural world, to make it happen, and therefore to make the natural world identical to the moral world that God sees, and will see to, making sure it will happen. Thus, the necessity of cause and effect becomes an act, quite literally, of transforming events from passive nouns to active verbs. God, in a very real sense, is seen here as actively putting to work grace, constantly adjusting reality to match ideological ends, to make them one and the same. ${ }^{139}$

When Edwards returns a few pages later to this theme, he again, symptomatically perhaps, confuses his terms in the original text:

'Tis manifest, the moral world is the end of the natural ... and the good or bad state of the moral world depends on the improvement they make of their natural agency, and so depends on their volitions. (255, my emphasis)

139 The recent film The Adjustments Bureau (2011, based on the Philip K. Dick short story, "Adjustment Team") provides a useful, if troubling, example of this scenario, where a god-like yet indeterminate "Chairman" and his "Bureau" make minimal "adjustments" to reality in order to fulfill an equally indeterminate "Plan." As bureau agent Richardson says, "You don't have free will, David, you have the appearance of free will." Of course, in the movie version of predestination, the plan goes awry, and the lead characters' demonstrated love changes the Chairman's mind, who rewrites the Plan to allow them to stay together. Free will conquers even the most benign version of determined fate - except for the fact that their attraction to each other is a holdover, what Žižek might call an excremental remainder, of a prior version of the Plan. Their choice of each other over the Plan turns out to not be choice at all, but the ultimate fulfillment of the Chairman's will (Nolfi). 
This time Edwards himself, in the printed list of errata for his first edition, changes the word "natural" to "moral" in the latter part of the sentence, but we can read in the original, mistaken version an underlying truth, in that the natural world is both caused by and is the cause of the moral world, and changes to the natural world are completely and without exception moral in nature. Put in the covenantal language of Edwards's Miscellanies, the covenant of grace is the end of the covenant of works, but only in fulfillment of the covenant of works; it all comes down to the natural yet passive agency of the gracious event.

While Edwards may chide his Arminian opponents for claiming indifference as "the passive ground or reason of [moral] action," he in fact lends support to just such a contradictory truth (228). ${ }^{140}$ Will is only free when it is unconscious, when it no longer controls nor seeks to understand its own freedom, when it no longer seeks a freely willed choice behind an act of will. Thus, when Edwards argues for what distinguishes virtue from vice, he is also arguing against the distinction between the content and the form of virtue, in that any inducement to act virtuous can be interpreted as working against virtue in the form of liberty:

This notion of liberty and moral agency frustrates all endeavors to draw men to virtue by instruction, or persuasion, precept, or example: for though these things may induce men to what is materially virtuous, yet at the same time they take away the form of virtue, because they destroy liberty ... (331)

Structurally, then, moral action or virtue as dependent on liberty transforms virtue into a formal and theoretical concept rather than one comprised of moral content- - the exact reversal of form and content that Žižek argues for. While Edwards claims that this effectively removes God from

140 Edwards calls this "a remarkable phrase; than which I presume there is none more unintelligible, and void of distinct and consistent meaning, in all the writings of Duns Scotus, or Thomas Aquinas." 
the terrain, we can see instead that this inserts mankind into God's terrain of moral liberty. As Edwards maintains, we are responsible for our moral acts "not so properly because they are from us, as because we are in them, our wills are in them; not so much because they are from some property of ours, as because they are our properties" (428, his emphases). In this way, we can see the complete conversion of the covenantal structure beyond Edwards's observations in his Miscellanies, in that we are both within and coterminous with the covenant of works, in that our very moral existence is a property of our works, which work through us via grace. Thus, the covenant of grace infuses us with the dictates and values inherent in keeping the covenant of works, and yet divests us of an ability to perform. We are, in the end, simply left with the properties of active preference to achieve our passive goals. In other words, we are left with the positive property of preferring not to in order for grace to negatively work through us.

Susan Wolfs suggests that Edwards offers, as an alternative to both compatabilism/determinism and freedom/autonomy, a "Reason View" for the liberty of human motivations, which claims "the freedom necessary for responsibility consists in the ability (or freedom) to do the right thing for the right reasons - or ... the ability (or freedom) to choose to act in accordance with the True and the Good" (qtd. in Adams 329). In one sense, one could say that such a view is a mere restatement of Edwards's perspective, in that the will is already determined to do right (or wrong) based on its strongest motivation, which can only be the "right" reason. However, in another stronger sense, the true identity is between will and freedom, in that the will is only free to do what it is most strongly motivated to. Therefore, one is more accurate to say that one's ability to act "freely" outside of a deterministically motivated system is precisely the ability to do the right thing for the wrong reason. ${ }^{141}$ This, one might say, is the true

${ }^{141}$ Edwards, as one might expect, does not look kindly on the idea of doing the right thing for the wrong reason, but 
definition of freedom from a deterministic world view, and the paradox lying at the center of the covenant's matrix of meaning.

In the end, the covenant formulation creating an identity of grace as works allows the mind to act "without motive," or rather, transgressively asserting a prior motive through a subjunctive retro-active act of interpretation. This is similar to Zizek's attempt in The Fragile Absolute and In Defense of Lost Causes to think of the past as a repository of motivations not for what has already happened but for what was meant to happen, of subjunctive potentiality that is, in a sense, predetermined by our future acts. The covenant, in this way, must be read back into history to reorient the present, creating one's liberty by pre-contextualizing one's freedom. When Edwards asks, "Can there be previous ground in a thing for an event that takes place, and yet no previous tendency in it to that event?" we can provide a full-throated Žižekian "Yes!," qualified only by an understanding that this can only occur in revolutionary circumstances. Such an "absurd" positive response must also assume "that the previous tendency of an antecedent to a consequent, is the ground and reason why that consequent does not follow." This leads to the "ground" for the truly revolutionary unmotivated act:

An act of choice or preference is a comparative act, wherein the mind acts with reference to two or more things that are compared, and stand in competition in the mind's view. If the mind, in this comparative act, prefers that which appears inferior in the comparison, then the mind herein acts absolutely without motive, or inducement, or any temptation whatsoever. (231-2)

does recognize that such circumstances can exist when a "negatively good influence" can assist in avoiding "positive evils." This negative potential for situational ethics comes up in questioning the potential for "a great and unknown deceit, arising from the ambiguity of the phrase, 'sincere endeavors,"' and he provides as an example a man who saves another man from drowning only in order so that the second man can pay a debt owed to the first man (315-6). 
This possibility of active indifference can be otherwise described as the active work of grace, in that one cannot and at the same time cannot help but be virtuous through and thus saved by the passive, unmotivated activity of grace. In the language of Herman Melville's short story "Bartelby," one must actively "prefer not to," to perform an unmotivated act, to truly change the world.

It is fitting to refer to a nineteenth-century work of fiction (and one of Zizek's favorites) as both a literary attempt to create a positive resolution (if it can be called that) of Edwards's theological impasse as well as a transition to discussing Emerson's complete conversion of the covenant into a personal-political "constitution." I would add, however, that it is only by slogging through the dense theological tracts of the past and equally dense theoretical materials of the present that this simple statement of political ideology, "I would prefer not to," attains (if it ever does so) its immanent political force. The calling to impossible political action, read out of and against Edwards's theological arguments, functions as both a refutation of Edwards's opponents - they would be as horrified by this conclusion as Edwards - as well as a validation of what can only be called Edwards's ideological analysis of Reformed Protestant theology, and of the covenant in particular. By working out and arguing against the inevitable structural "motivations" born out of covenant theology, Edwards sets up the nineteenth-century Arminian arguments for self-determination taken up by Emerson and the Transcendentalists. We will see that his formulation, though formally breaking away from the strictures of Reformed Protestant theology, nevertheless are equally predetermined by the past. 


\section{CHAPTER 4: EMERSON'S CONSTITUTION}

To repress Emerson's difference is to deny that America is as transcendentalist as it is pragmatist, that it is in struggle with itself, at a level not articulated by what we understand as the political.

Stanley Cavell, "What's the Use of Calling Emerson a Pragmatist?", 223

Has America happened? doubtless the question is romantic. Then the question is posed: Is there a way alternative to the romantic to ask the question?

Cavell, "Finding as Founding", 137

Faith makes us, and not we it, and faith makes its own forms. Ralph Waldo Emerson, "Divinity School Address," 91 I will have no covenants but proximities.

Ralph Waldo Emerson was brought up and served briefly as a minister in the early nineteenth-century Unitarian Church, the direct denominational descendant of the "liberal" or "rational" movement within the Congregational establishment. His subsequent lectures and essays all bear the mark of this theological and professional background, as would be expected. 
What is less expected is the distance Emerson manages to put between himself and the Congregationalist tradition. Though he sounds the proper jeremiad note in his denigration of contemporary Unitarianism and pays lip service to the historical forefathers of New England as examples of the courageous souls he is hoping to inspire, his "Calvinists" are little more than stereotypes, figures on the shore similar to those on the dustcover of Sarah Vowell's book (see footnote 4).

Emerson's disregard for his immediately theological past, one with which he was certainly familiar, is especially true of the peculiar version of Reformed Protestant theology of the covenant, which receives a similarly emphatic but unsystematic use. What is more, almost every use of the term "covenant" in Emerson's essays is associated with the unsettled, the proximate, the transitional, the indeterminate, the negative; if we were to line them all up, his insistence on there being "no covenants" would be deafening ${ }^{142}$ — an understandable approach to Calvinism by an early nineteenth-century liberal, perhaps, but, as I hope to show, demonstrating a deeper meaning, a sounding of the conflict inherent in the Reformed Protestant conceptual matrix of the covenant we have been tracing, and which I argue, over Emerson's objections, is still operative in his work.

The passage where the use of the word "covenant" lies most thick is in his "Fugitive Slave Law" address, given in New York City on 1854, where he employs the term to express his ultimate skepticism regarding American politics following what he considered the betrayal of Daniel Webster in supporting the laws' passage:

142 "Covenant" in its various forms appears just 25 times within Emerson's essays, and when not being descriptive of the commitment of marriage or friendship, most often appears in a statement questioning or challenging similar commitments (Irey). See, for example, the last quotation in this paragraph's epigraph, as well as the following quotation from the essay "Circles": "Nothing is secure but life, transition, the energizing spirit. No love can be bound by oath or covenant to secure it against a higher love ... People wish to be settled; only as far as they are unsettled is there any hope for them" (413). 
I fear there is no reliance to be had on any kind of form or covenant, no, not on sacred forms, - - none on churches, none on bibles ... These things show that no forms, neither Constitutions nor laws nor covenants nor churches nor bibles, are of any use in themselves; the devil nestles comfortably into them all ... Covenants are of no use without honest men to keep them. (1002)

Covenants in the spiritual world, like constitutions in the secular, are no longer arbiters of eternal or national greatness, keepers of the perpetual promises of God or man, but are instead empty forms, with no validity or independent force, unexecutable, capable of mischief and even evil.

One might say at this point that I should not read Emerson too literally, that he is overstating his case in this address, filled as he is with outrage and uncomfortable (as he explicitly mentions at the beginning of the address) when speaking on "public questions." However, looking back to the quotation in this chapter's epigraph, even when speaking on "private questions" Emerson not only makes a similar claim but appears to embrace this lack of solidity and foundation in his sacred forms: "I will have no covenants but proximities" (my emphasis). This statement is not reducing the validity of a sacred form but instead raising the value of proximity as sacred and formal, taking on, literally, a form of sacredness. For what is proximity but a relationship by a different name, a relationship that is not so much "struck" or "broken" like an ancient covenant but assumed, intuited, recognized, transfigured, converted, spoken and written? These latter terms are key to understanding Emerson's cosmology and political philosophy, and while I do not seek to have "covenant" join their ranks, I do suggest that the inherited theological form of the covenant informs Emerson's faith on its own terms. In doing so, I will be very un-self-reliantly depending on the work of Stanley Cavell, whose efforts to 
philosophize Emerson, to make reading Emerson safe for philosophy, I hope to replicate in understanding how Emerson's work "reads" the Reformed Protestant theology of the covenant into America's relationship with itself.

\section{Unconscious Theology - Reading Emerson}

In ending with Emerson, this study has come full circle, in that Emerson is demonstrably the inspirational figure for Perry Miller's interpretations of early American literature with which we began. Miller's work embodied Emerson's call in his essay "The American Scholar" for charting an independent path, though it was Sacvan Bercovitch, much more so than Miller, who fully envisioned an American literary tradition from the Puritans through Emerson to today, a tradition based not on struggle toward modern supremacy but toward the establishment of middle-class decency:

It was the Emerson connection that spurred my interest in the Puritans, and the influence of Emerson, as I see it, casts a long shadow forward in American culture, even unto our own times. (qtd. in Fuller 125)

This shadowy influence is often characterized as a "haunting," which connotes both a sense of remaining undead and of having "effected psychological transformations upon individuals in ways that remain to some extent mysterious and unpredictable" (3). ${ }^{143}$ Miller suggests that this uncomfortable reception of Emerson comes mostly from his espousal of metaphysical principles that are as unsupportable as they are unavoidable in the American cultural context:

\footnotetext{
143 Fuller cites Harold Bloom's characterization of Emerson as "our ghostly father" at the beginning of his book, Emerson's Ghosts, which describes Emerson's "haunting" influence over the field of American literature, including chapters on Matthiessen, Miller, and Bercovitch.
} 
Although the metaphysic of the Over-Soul, of Self-Reliance, and of Compensation is not one to which we can easily subscribe, yet if the particular formulations were restatements of a native disposition, then we who must also reformulate our traditions may find their philosophy meaningful, if not for what it held, at least for whence they got it. (Miller, "Edwards to Emerson" 591-2)

Not all readers of Emerson agree that he reflects a "native disposition," or even any disposition, systematic or otherwise, at least not one of which he was conscious. For all of Emerson's insistence on self-awareness, it is ironic that his critics contend that he lacked awareness of his own meaning, as was found by Barbara Packer in her influential book, Emerson's Fall:

No one who reads much of the critical literature about Emerson can fail to be struck by the number of critics who assert that Emerson was unconscious of some significant implication contained in, or response likely to be provoked by, his own texts. (Emerson's Fall 19-20, her emphasis)

Later in her book, Packer points out that "dislike for Emerson has a history, a history that includes us whether we want to be included or not," and she quotes James Cox's claim that the aversion many readers have to Emerson "discloses attitudes which could well be considered expressions of precisely this vision [of the relationship between Emerson's life and work] held unconsciously" $(56,52)$. Michael Lopez, similarly, cites an "anti-Emerson tradition" that is "a largely unconscious part of Emerson scholarship" (245). In other words, the unconscious collaboration of Emerson with his own work becomes the aversive reader's unconscious collaboration. ${ }^{144}$

144 I am suggesting that this may be a version of the particular form of Žižekian (rather than Jamesonian) "political unconscious" as described in chapter 1. 
Nowhere is this more apparent than in Emerson's reception in literary studies. Miller found that the chief failing of the Transcendentalist movement which Emerson helped to found was generic, "their precommitment to making literature a substitute for religion, and religion a substitute for philosophy" ("Introduction" 14). Basically, in Miller's reading, Transcendentalism was originally a religious movement that became literary by mistake, born out of the adepts' need to express their spiritual longing, and, without an active New England theological culture as in past centuries, they turned to the aesthetic forms of European Romanticism. Regardless of its provenance, the transcendental turn from religion to literature has been aided by Emerson's placement at the beginning of American literary tradition, most magisterially by F. O. Matthiessen's groundbreaking American Renaissance (1941). Emerson's influence on literary studies has been definitive and determinative, expressed by Richard Poirier as an unconscious ideological founding: "[H]is works now constitute a compendium of iconographies that have gotten into American writers who may never have liked or even read him" (qtd in Doherty 65). Emerson started going through a "critical reconstruction" in the early 1980s American Studies discipline, with critical focus shifting away from Miller and Bercovitch's focus on his transcendentalist break with the religious tradition and toward a cultural analysis of his ideology of individualism. ${ }^{145}$ His reputation in the last two decades has grown exponentially, his "philosophies ... embraced within the variety that now defines literary study," to the point that "[n]o account of American thought—be its emphasis on philosophy or theology or society or politics — can be complete without reference to Emerson" (Wolfe 137; Wider 2; Padover 334). On the literary front, Harold Bloom has been the chief enthusiast for the reconstruction of

${ }^{145}$ For an excellent historiography of Transcendentalism from both the historical and the literary perspective, see Capper. 
Emerson's reputation, maintaining Emerson's unconsciously aversive affect on his reader but giving it a positive spin, proclaiming (in proper Bloomian fashion) that Emerson is "the inescapable theorist of virtually all subsequent American writing," is, in fact, the American literary tradition, "is—simply—ourselves, perhaps for worse ... we are still, in our accursedness, Emerson's contemporaries and his involuntary disciples" ("Emerson" 546, 556; "Mr. America"). ${ }^{146}$

Key to Emerson's critical reconstruction has been the work of Stanley Cavell, who has attempted to bring a similar vision of Emerson's unconscious centrality yet aversity to the surface for the American philosophical tradition. Cavell is credited with identifying Emerson as "the founding figure in the American philosophical tradition" (Porte and Morris xiii) and wrote a series of essays over two decades that posit an ethico-philosophical edifice for Emerson's works (Transcendental Etudes 194) $\cdot{ }^{147}$ Cavell was not the first to call Emerson a great philosopher and place him at the head of the American tradition. Charles Capper credits George Santayana as bringing "Transcendentalism for the first time in American intellectual history into the ongoing stream of modern philosophy" by connecting its self-reflexivity and hyper-individualism with a scientific-like method of observation, what Santayana calls "systematic subjectivism" in his 1911 lecture "The Genteel Tradition in American Philosophy" (512-3). John Dewey famously faced down skeptics of Emerson's ability to build a logical system for his thought, praised Emerson as

146 David Fite, in a comprehensive reading of Bloom, identifies Bloom's parallel treatment with previous American literary criticism of "Emersonian individualism as a desire for pure vision unencumbered by ties to the past and his placing of that desire in a central position in American literature," but Bloom leaves these critics behind (and, of course, does not cite them) while he is "busy translating the tale of Emersonian individualism into the paradigms of his own rather extreme critical prophecies" (93-4).

147 Most of Cavell's key works on Emerson, originally published in disparate collections of essays and lectures, have been gathered into a single volume, Emerson's Transcendental Etudes (2003). My references to Cavell's writings will be from this volume, unless otherwise indicated. 
"the Philosopher of Democracy," and claimed him as the founder of American Pragmatism. ${ }^{148}$ However, as Cavell points out, Dewey never took up Emerson philosophically (12), and Cavell's detailed philosophical analyses of his texts, as we will see, questions this pragmatic alignment. ${ }^{149}$ Nor does Cavell seek to limit his understanding of Emerson to philosophy and away from literature—he calls philosophy and literature "halves of my own mind" (33)—or religion. Indeed, the role of both disciplines are determinative in understanding Emerson and American philosophy; as Cavell points out, European philosophy established itself through "quarreling with religion," but American philosophy instead quarreled against the romantic lyricism of Emerson and the Transcendentalists, which is part of the reason why they are still considered "philosophical amateurs." Indeed, according to Cavell, "this communication between philosophy and literature, or the refusal of communication, is something that causes romanticism," that represents the expression of "an intimacy with existence, or intimacy lost," a marker called Transcendentalism representing "what became of romanticism in America" $(44-5,59,36) .{ }^{150}$ Stephen Melville indeed identifies in Cavell himself a romantic proclivity for a "certain insistence on a necessary indirectness in our grasp of things, including ourselves and our situations," which leads to "an absolute solidarity of any registration of that indirectness with the difficult act of writing, itself understood as always also an act of reading" (177).

148 Dewey claims that those who find Emerson to not be a philosopher betray an "incapacity to follow a logic that is finely wrought" and bluntly accuses literary critics of bad faith: "The condescending patronage by literary critics of Emerson's lack of cohesiveness may remind us that philosophers have no monopoly of this particular form of stupidity" (405-6).

149 Cavell expresses doubts that pragmatism is in fact "expressive of American thought" (42, see also his essay "What's the Use of Calling Emerson a Pragmatist?", 215 passim).

150 T.S. McMillan seeks in Emerson an answer to the right uses of literature, which is part and parcel to the issue of the right uses of Emerson, answering the question, "What is Emerson for?": "Our literary history makes clear that the figure of Emerson has created numerous problems for American readers of Emerson's texts" (2-3). McMillan's solution is to just get rid of Emerson and start reading him anew - an Emersonian solution if there ever was one! McMillan ends with a focus on Cavell's reading of Emerson, answering Cavell's question about how we learn to read Emerson in order to learn to read American philosophy by pointing toward a "natural philosophy of reading" $(125,129)$. 
At the beginning of one of his essays, Cavell formulates a question that circulates through his writing on Emerson, and is as much about reading Emerson as it is about philosophy: "[W]hat is the state in which the claim of philosophy is refused and yet a claim upon philosophy is entered?" (111). This particular form of Emersonian "double consciousness," this refusal to claim what has unconsciously already claimed by you, is, I argue, best understood not from a literary or a philosophical but from a theological perspective, and particularly through the Reformed Protestant theology of the covenant. Cavell points to Emerson's internalized attempt to end both philosophy and theology, to bring both to an end in his metaphysics of the soul:

Emerson evidently requires the replacing of theology as well as of philosophy ... We might think of this as internalizing the unended quarrel between philosophy and theology. (15)

For Bloom, Emerson does this by ridding himself of Christianity and becoming a theologian of a new "American religion," a religion that is "Protestant without being Christian," a peculiar blend of spiritual gnosticism and aesthetic solipsism that creates an ideological foundation for American poetics and cultural idealism ("Mr. America"; see also American Religion). ${ }^{151}$ However, what Bloom's criticism lacks is the "unending quarrel" within the philosophical formulation of Reformed Protestant theology, which is elemental to this unending ending of both philosophy and theology (let alone Christianity). ${ }^{152}$ In order to understand how this conflict works, we will have to look beyond the practices of literature and religion to the theories of

151 Capper suggests that "the more theologically radical Transcendentalists were thought many, both at the time and since, to have founded new religion," but there is little evidence and few citations (except, of course, to Bloom) that support this summation (533).

152 Another of Blooms' fundamental misunderstandings, held is common with many cultural and literary critics, is his positioning of the genesis of both American literature and religiosity in the early- to mid-nineteenth-century "renaissance" of both literary and pentacostal expression instead of the theological underpinnings of both, which can only be understood through a theoretical reading of earlier writings. 
politics and theology_or, rather, look through the practices to understand the theories that, in turn, reflexively provide their support.

In short, while many contemporary readings of Emerson appear to have moved beyond the emphasis Miller and Bercovitch placed on the religious aspects of Emerson's works, it is my argument that they have internalized the unconscious conflictual dynamics inherent to the theological underpinnings of his work. ${ }^{153}$ One reading that directly addresses this fundamental internal conflict is Stephen Whicher's influential Freedom and Fate: An Inner Life of Ralph Waldo Emerson (1953). Whicher traces the "double consciousness" inherent in Emerson's work between the mortal and immortal self, which Whicher immediate connects to "Calvinistic pietism" of both the original Puritan settlers and of Jonathan Edwards:

This fact may help to explain the kinship which every student of Emerson comes to perceive between [Emerson] and the greatest American Calvinist, Jonathan Edwards. (22)

Whicher cautions, however, that Edwards, particularly in Freedom of the Will, seeks to "demonstrate exactly what Emerson denied ... True virtue is only possible through a miraculous infusion of God's grace into the soul." Emerson, however, was able to transform this infusion conceptually from a unilateral election of a few to the birthright of everyone. Two facts can be immediately derived from the above: 1) Whicher was a former student of Perry Miller's and internalized his perspective on the importance of the Puritans and Edwards; and 2) from his title, it is clear that his study is a spiritual biography, a hero's tale of an intellectual who braved America's ideological monsters, Christianity included, came up with one courageous idea, and

${ }_{153}$ Dauber addresses the contemporaneous critical resistance to Emerson by identifying a resistance within Emerson's dialogue with his own ideals, between idealism and social activism, resulting in his applying his "centrality" in American self-identity to the margins of American society. 
dwindled into his dotage. Here, Emersonian scholarship is in keeping with Emerson's stated ideal to make all history biography, but the underpinnings of that ideal—-the theology behind the thought—are not so easily related through hagiographical treatment. ${ }^{154}$ Cavell, perceptively, points instead to the undecidability of the American cultural relationship with Emerson, "as if we do not yet know what this man is and what he wants" (54).

Instead, I will draw on what Edward Duffy calls "the religious conditions of Cavell's philosophical practice" (575) and what Cavell, in his Themes Out of School, calls his "theology of reading" (53), understood in the sense that Emily Budick describes as a "contractual relationship of aversive acknowledgement" (226). Part of these religious conditions is the unconscious acknowledgment of what Cavell in various places calls "our poverty" in that "the task of philosophy after philosophy is, in a sense, impossible," which leads Emerson to not "found" an American philosophical system but instead to "find" it, as it were, already here (Wolfe 140). This after-effect of philosophy, one could say, is the only way to find one's philosophy, to understand where you have already been. What Cavell is pointing to is the particular ordinariness of American philosophy, and of Emerson - he is always familiar, not just because he has infected American ideology but that he was already infected by it. Cavell's claim to Emerson and to his vital project of moral perfectionism is not historical excavation but an identification of how the Reformed Protestant project is reclaimed through Emerson and Cavell for us, is in fact predetermined by its claiming, after the fact. It is in this light that we can attempt

154 As mentioned in the introduction, Bercovitch's The Puritan Origins of the American Self (1975) is still the best explication of the Puritan beginnings of the ideological trend of American hagiography, which without question continues into Emersonian scholarship. Emerson must be read, always and insistently, in light of his own fame, and the history of the waning and loss of that fame, with frequent (and current) revivals. However, the emphasis on the biographical in Emersonian criticism, begun with Whicher and replete in the literature, holds the potential to obscure readings with an extra overlay of romantic engagement with Emerson's life rather than his texts. 
to understand how Emerson ended the unending conversion of the Reformed Protestant

covenant.

\section{Emerson's Monsters - Theorizing Emerson}

As mentioned above, Emerson does not delve deeply into theological concerns in his essays - understandably so, as their purpose was to promote Transcendentalism as a philosophy rather than Unitarianism as a theology or religious practice — but he lived within a community defined by its religious history. Better known to themselves as "rational" or "liberal" Christians, the early Unitarians sought to chart a course between the orthodox and evangelical Christians on one side and the radical, "free" religionists on the other, developing a mode of belief based on an historical understanding of scripture and the moral improvement of humanity (Wright, Liberal Christians; see also Grodzins). ${ }^{155}$ Conrad Wright describes Unitarianism as the impact of New England Puritanism and the Enlightenment, and gives due credit to Calvin for providing the Unitarian theological frame of reference, to the New England Puritans for providing their congregational polity and religious seriousness, and finally to Edwards for posing the fundamental question of human capacity to effectually respond to the call for conversion. ${ }^{156}$ The result, by the end of the eighteenth century and through the work of liberal theologians such as

Charles Chauncy and Jonathan Mayhew, was a "structure of doctrine that was Arminian as to the

155 Conrad Wright since the 1970s has made a fair understanding of Unitarianism a requirement for any study of Transcendentalism from the standpoint of religion, which may be part of the reason studies of Transcendentalism have veered away from this avenue of analysis (Wright is not dry, but he is certainly methodical). The Unitarians eventually succumbed to the ancient if not proud tradition of adopting the name provided by one's enemies. The name "Unitarian" was accepted as early as 1819 , but preference through the 1830 s was to be called "liberals." Hutchinson posits the theory that, due to the lack of a positive theological or denominational identity for so many years, Unitarianism was generally viewed as a "negative system" during that time, a view carried forward by Emerson's sharp comments about Unitarianism (Hutchison 2). For example, H.C. Goddard claims Unitarianism was a "negative" movement, a "reaction from Calvinism" consistent with the "critical century in which it appeared" (165).

156 Whicher calls Emerson's Puritan heritage "the most important single fact about him" (viii). 
doctrines of grace, rationalistic as to epistemology, and antitrinitarian as to Christology"

("Introduction" xi-xiii).

Most scholars of the Transcendentalist movement, following Miller, generally conceive it as a religious movement or "demonstration" within Unitarianism, one in a series of "enthusiasms" that regularly swept through New England Protestant history (Miller, "Introduction" 8; Grodzins; Robinson, "Transcendentalism" 16). Miller observes that "in the first years of New England Winthrop and Cotton had very bitter experience with a similar doctrine," namely during the Antinomian Controversy, and most scholars have followed his lead in identifying Transcendentalism as the reappearing of the mystical strain of Anne Hutchinson's "immediate revelation," what might be called a religious rather than a theological phenomenon ("Edwards to Emerson" 595). ${ }^{157}$ Alan Hodder, for instance, finds that the significant scholarship on the relationship between Unitarianism and Transcendentalism make out the latter as "a religious family affair, a generational tug of war, a 'reform impulse' within the liberal faction" of New England Reformed Protestantism (425). While David Robinson is justifiably in considering Emerson "the most influential inheritor of the liberal theological tradition" (Apostle of Culture 2), the negative view of Unitarianism in Emerson studies, and of theology in general in literary studies, may also be justifiably laid at Emerson's door. Robinson finds that the differences between the Unitarians and Transcendentalists are more affected than factual, a matter of style over substance. ${ }^{158}$

${ }^{157}$ Caroline Healey Dall, in 1897, was the first to make the explicit connection between Anne Hutchinson and Transcendentalism, in the context of a continuum to the later women's rights' movement (Capper 507). For the most recent review of the linkage between Unitarianism and Transcendentalism, including the distinction made by both between religion and theology, see Grodzins.

158 Miller's influential pronouncements of the enthusiasm of Transcendentalism over the rational coldness of Unitarianism seems to feed into this model. 
Apart from their nominal issue with Christology and biblical interpretation, Unitarians' "practical disagreement" with orthodox Calvinism was over human agency, which in theological terms was essentially Arminian. This led to their conceptualization of God's "moral perfection," a central concept for Emerson's own brand of this doctrine; however, it is important to note that Emerson received this theology as a "doctrine of human nature rather than [a] doctrine of God" (Hutchison 4-5). Thus, "Emersonian perfectionism," a version of Unitarian "moral perfectionism," is not simply becoming the god within you but, in Cavell's terms, requires us to understand and to enact what it means to suffer, to experience illimitable life but only within a proscribed framework of freedom (184-8). Similarly, Emersonian views of art, beauty, and culture can be considered gradations of Unitarian beliefs. Daniel Howe, in his comprehensive overview of Unitarian moral philosophy at Harvard in the first half of the nineteenth century, describes the development of a theological basis for literature as a "means of grace" by "Unitarian moralists" or "Christian humanists" (Unitarian Conscience 197-201). Most importantly from a theological perspective, the Unitarians reconceived the Congregationalist tradition's conversion experience into the "formation of a Christian character," a version of the seventeenth-century New England Puritan doctrine of "preparation for grace" which Hutchinson saw as the preaching of the "Covenant of Works" during the Antinomian Controversy of the 1630s (116). Unitarian moralists preferred the term "regeneration" and we can see Emerson adopt "transfiguration" to mean much the same thing, except retaining the mystical element of the change within. ${ }^{159}$ Robinson describes Unitarian "self-culture" as a theological process of

159 One can say, in fact, that, far from a crisis, the Transcendentalist period is considered "'the golden age' of American Unitarianism", culminating not just in Transcendentalism but also--and one could argue more importantly--in the educational reform of Horace Mann and the abolitionism of Theodore Parker and Thomas Wentworth Higginson (Howe, "Morning Blest"). It should also be noted that the Transcendental movement was overwhelmingly Unitarian, both professionally as well as culturally; of the of the 26 original members of the "Transcendental Club", 17 were Unitarian ministers (Hutchison 44). 
"conversion," the end result of which was a "new teleology ... which stressed [moral] fulfillment rather than deliverance as the goal of human existence" (Apostle of Culture 12, 27).

In the end, Miller says he cannot explain why Emerson turned from Unitarianism to Transcendentalism, leaving it to other critics (most notably, Whicher) to make the attempt at explanation ("Edwards" 45-58). However, stepping back from intellectual history to the tracing of a concept, we can see the delineations of the Reformed Protestant covenant reappear in Romantic clothing. Transcendentalism can be seen as a "logical outgrowth" of Unitarian arguments in favor of human freedom and agency, as well as its openness to literary expressions of faith (Buell, "Literary Significance" 213), but the doctrinal differences on mankind's relationship to God were no less real, and can even be viewed as a particular form of Unitarian "awakening" that was, like other revivals, gradually subsumed into the transformed yet normative church establishment (formally organized as a denomination in 1865) (Howe, "Morning" 45-58). The most significant doctrinal difference is suggested by Robert Milder, who claims that Emerson's work effectively levels the same charge against the Unitarians that Edwards does against Arminians, "that they preached a doctrine of works, or, in the language of philosophy, a religion of the Understanding." Emerson recast the Calvinist disjunction between nature and grace into Coleridge's Romantic idiom of reason and understanding, locating the fount of redemptive vision within the human mind. The impact of Emerson's reading of Coleridge's Aids to Reflection was "to respiritualize orthodox religion by severing it from the Lockean sensationalism Edwards had used to shore it up" (29-30). This helped Emerson lay the groundwork for his critique of Unitarian moralism by way of experiential transformation or conversion from within. 
As for Edwards, it is known that Emerson read Freedom of Will in 1823 and other of Edwards's writings thereafter, but little has been found to directly connect their ideas (Hodder 427). A cottage industry of critical effort to find these connections was born following Miller's publication of "Jonathan Edwards to Emerson" (1940), which Robinson calls "one of the great acts of synthesis in American literary history" (qtd. in Fuller 45). We have already seen how Edwards is linked to the age of Emerson and to the Transcendentalist movement through the historical series of successive awakenings, when the Great Awakening was revived and relived during what came to be known as the Second Great Awakening, extending from the 1790s through the 1830s mostly led by New Divinity Edwardseans, and determined the course of parallel theological developments such as its Unitarian criticism of "enthusiasm" (see Conforti 32 passim). Additionally, according to Miller, Edwards "strained theology to the breaking point" to hold it back from its natural pantheistic outburst that eventually would be Emerson's product: Holding himself by brute will power within the forms of ancient Calvinism, he filled those forms with a new and throbbing spirit ... But take away the theology, remove this over-lying stone of dogma from the well-springs of Puritan conviction, and both nature and man become divine ("Edwards" 605).

Beneath all the throbbing, Miller makes an interesting and telling construction of proposing to roll back theology to discover ... theology! In other words, it is the theology itself and not some naturalistic, pan-like exuberance that is its own outbreak, and that it must now contain. Roger Lips, in his detailed exposition, ${ }^{160}$ suggests that both Edwards and Emerson held similar views on

${ }_{160}$ Lips characterizes his dissertation as offering the "volume of documentation" that Miller said would be required to flesh out his suggested connections in "From Edwards to Emerson." Lips points to the fundamental problem of seeing a continuity between Edwards and Emerson: "Emerson's father was Arminian and Unitarian, an intellectual descendant of men with whom Edwards had fundamental difference, and Emerson grew up thinking of himself as Unitarian" (12). There is no evidence that Emerson made a study of Edwards's thought, though Emerson's influential Aunt Mary Moody Emerson was a fan of Edwards (see Cole). 
the division of faculties between "understanding" and "will" and that furthermore "both believed the Understanding instructed the Will, so that in natural men, the sense instructed the Will to gratify the natural appetites, while in spiritual men, the Moral Sentiment instructed the Will to satisfy itself in God." He also finds major similarities between Edwards and Emerson in the "conversion experience" (25-6; see also Knutson; Hodder). Conversion, we should remember, in the Reformed Protestant context is the operative relational moment between God and mankind, something that is both temporal and anachronistic, in that one must always already hold the power of being chosen, elected by God for conversion. Finally, many scholars have pointed to similarities between Edwards' expansive use of typology to find confluences not just between the Old and New Testament texts but between biblical promises and natural phenomena, what Emerson came to call "correspondences" (see Lowance; Metzger; Hall, "From Edwards"; Mott; Paul). What should be noted is the double move between Edwards and Emerson, in that Emerson represents the Arminianism that Edwards was arguing against, and yet Emerson carries forward many of the attributes of Edwards own argument. One could call Emerson's work the affirmative negation of Edwards Freedom of the Will or, rather, the positive expression of the negation already incorporated in Edwards's work.

Whicher comments near the end of Freedom and Fate that Emerson's work dwindled from an "originary protestant perfectionism thinly disguised as 'modern philosophy,' [to] his eventual acquiescence close in spirit to what [William] James called soft determinism" (172). I argue that what underlies both Emerson's perfectionism and his "soft determinism"—another name for a compatibilism between freedom and determinism (James) — is hard theology, and all Protestant. What is required is to think theology differently, not teleologically (i.e., religiously, 
concerning the ends of faith) but tautologically (philosophically, concerning the ends of ends). Cavell warns, rightly, "[w]ere philosophy to concede such a place, one knowable in advance of its setting out, philosophy would cede its own autonomy" (18). I suggest that Emerson does cede this autonomy, quite loudly, but in a positive, doubled way, through his over-identification and mystification of the end-point through his seductive tautologies of soul, nature, and law. What's more, these tautologies are replicated in Cavell's explication of Emerson's philosophy, in particular the identification of enthusiasm (for) and abandonment (of) in self-reliance-as-text.

A central question from this perspective is how much Emerson's clear dissociation from institutional religion and denominational theologies leads to a dissociation from religion and theology itself, or what Irene Makarushka calls a "refiguration of the possibilities embedded in religion that surface once the critical process is set in motion" (xiv). The fundamental misunderstanding is that the theological underpinnings of religious belief and experience are transformed, auto-converted into something else, once external divinity is internalized. Once the God without becomes the god within, critics declare the death of God. This is a problem both from the perspective of ideology and literature, as Žižek has demonstrated. ${ }^{161}$ But it is most fundamentally a problem where Emerson is concerned, in that he inexorably continues to use Protestant theology as a basis for his ideological constructions.

Cavell takes these theological considerations one step further in his reading of Emerson, saying that appreciating Emerson as a philosopher requires a sort of "conversion" (210), something similar to what Emerson calls for in "The American Scholar": "the conversion of the world" (71). ${ }^{162}$ Emerson's thinking is explained by Cavell in many of his essays to consist of the

161 One could also, here, point to Kenneth Burke's work on developing a rhetoric of god-terms which is at the horizon of what Žižek is trying to say in terms of philosophy.

162 All citations for Emerson's works are from Emerson: Essays \& Poems (Library of America, 1996). 
Emersonian tropes of transfiguration and conversion, the conversion of experience into words, of intuition into tuition, a conversion that is "oppositional," "virtual," in time and in fact "aversion," and specifically aversion to religion and to society (144-5). Knutsen finds that "conversion" functions as the "site for adaptations in belief structures ... figuring the boundaries, or lack thereof, between the spontaneous and sensory perception of the environment and the bodies of knowledge that inevitably inform that environment," serving as "a central trope for theological, philosophical, and literary expression in America" (vii).

Our interest, however, is not so much in the morphology of conversion in Emerson but in its application to the conceptual matrix of the covenant, the interrelationship of grace and works, of divinity and secularity. ${ }^{163}$ One aspect of Emersonian theogony that is often missed, in all of its self-centeredness, is its radical predestinarian logic. In attempting to describe Emerson's "religious imagination," Makarushka contests that, "Independent of grace and other external mediation, Emerson believed that religion described the indwelling of the divine in the human" ( 9 , my emphasis). Makarushka's description of indwelling, as we will see, is in fact perfectly consistent with the Reformed Protestant theology of grace, which was never a mediation but a formal (covenanted) occupation. Emerson never precisely defines his usage of "grace" but does describe its operation as consistent with Puritan theology, with the "uniquely Christian elements ... subtracted," in his 1841 lecture "The Method of Nature" (Waggoner 68). ${ }^{164}$ However, the

${ }^{163}$ In the one piece of Emerson scholarship I found that mentions a direct connection between Emerson and the covenant dyad of grace and works, Robinson situates them directly in the "freedom of will" debate between the Calvinists and Arminians, but makes nothing of how the theology(ies) behind these terms operate in Emerson's essays, instead situating them vaguely, and typically, in Emerson's biography ("Grace and Works" 124).

164 Emerson provides the most important corrective to this process of interpretation in his "The Method of Nature" address. He says, simply, "Language overstates," and then gives as an example Empedocles stating "I am God," which was "a truth of thought" but, upon translation into language, "a lie to the ear" (119). We must take care in trusting Emerson's statements without attempting to elucidate the truth of his thoughts, or rather, the thoughts of his language. 
lesson of the covenant works/grace paradigm, as carried forward by Emerson, is that what Cavell calls "the primacy of practice" (219) (often mistaken for pragmatism) in Emerson's work is the beginning, not the end, of ideology, of the enactment of faith. It is the work that causes the faith, and all the mystification and self-identification and God-man-relationship to begin, heretically, with that fundamental act of obedience to a moral impetus outside oneself with which one is invested. The covenants of works and grace are not theoretical controls as much as conceptual expressions of this aversive, conflictual truth. Therefore, I am prone to agree with confessional critics such as Hyatt Waggoner who, when citing passages from Emerson's essays, finds "very little here that Thomas Shepard, Edward Taylor, or Jonathan Edwards would have felt obliged to alter or reject" (69); properly read—meaning, in a way that they all would reject—this is in fact the case.

In Emerson's sermon on the Lord's Supper, delivered as his farewell to the ministry and as an entrée to his career as most famous American man of letters, Emerson recreates Christianity as Idealism, with principle as form and theory as reality, a religious practice converted into a spiritualized, theoretical, impractical doctrine of feeling that, thought differently, is both practical (immediate) and impractical (internal), and the tension of which is the guarantor of freedom: My friends, the kingdom of God is not meat and drink. Forms are as essential as bodies ... That form only is good and Christian which answers its end. Jesus came to take the load of ceremonies from the shoulders of men and substitute principles ... [Christianity] is a moral system, that it presents men with truths which are their own reason, and enjoins practices that are their own justification ... What I revere 
and obey in it is its reality, its boundless charity, its deep interior life ... Freedom is the essence of Christianity. (964)

Later, when addressing the Divinity School scholars, Emerson would challenge the very essence of Christianity, the miraculous nature of Christ, calling "the word Miracle ... Monster":

But the word Miracle, as pronounced by Christian churches, gives a false impression; it is Monster. It is not one with the blowing clover and the falling rain. $(80)^{165}$

Emerson spent his subsequent career as a lecturer and essayist explicating this redefinition of Christianity away from monstrous words and toward the spiritual facts of a true Christianity-a career we will trace, with Cavell's interpretative help, through the remaining sections of this chapter. These elements can all be found in later essays: a sense of "causality" in the connection between ubiquitous reality and "the principle of being" ("Power," 797); "idealism" as the identity of nature and the mind, of the "world in God," which simply accepts "the pure and awful form of religion in the world" (Nature 32, 39); "self-trust" as being free "even to the definition of freedom," which means one must be "without any hindrance that does not arise out his own constitution," and yet part of one soul which animates all men ("American Scholar" 65, 67); and a calling to all people to be "fit" for immortality, or otherwise (frighteningly) considered "unfit to live" due to their "inequality to their own necessities," a calling recognized, ironically, by "performance" and, paradoxically, by "voluntary obedience" and "necessitated freedom" that seem to come right out of the most vitriolic pages of Freedom of the Will ("Worship," 901-2). And, shot through every sentence expostulating each of these theological principles is a

165 There is, of course, a clear link between Emerson's monstrous miracle and Žižek's aptly titled book Monstrosity of Christ, which argues for the revolutionary monstrosity of Christ's equally miraculous materialism; see chapter 1. 
substructure of tautologies, statements that resolve themselves and create equations of selfresolving meanings — "form only is good ... which answers its end," "truths which are their own reason," "practices that are their own justification," "I revere and obey ... its reality." This substructure, more than any overt theological construction, is at the heart of the concept of the covenant and its structural equation of inequalities to replicate divinity through man.

\section{The Nature of Grace - Nature and Addresses}

Emerson's work can be seen as culminating in his books of essays, but his "ground game," so to speak, occurred in his sermons, public lectures, and private journal, which fed directly into the publications. Bloom considers Emerson's journal to be his true literary achievement, his "authentic work" ("Mr. America"), but Emerson himself saw his whole effort as one piece; in an 1840 journal entry, he reflects on his concern for a unified theme: "In all my lectures, I have taught one doctrine, namely, the infinitude of the private man" (342).

My focus in this study will be on Emerson's major essays, but the "doctrine" found there came to fruition through public and private genres. As one can tell when reading Emerson's essays, he thought in terms of his first public form of expression, the sermon, whose purpose is the exposition of theological doctrine and the inspiration of congregants to put God's thoughts into practice. In his detailed analysis of Emerson's sermons, Wesley Mott finds Emerson's approach to Reformed Protestant doctrine to be more complicated than his self-confident assertions in his essays may suggest, specifically in regard to his full interaction with what Larzar Ziff calls the New England Puritan tradition's perennial "tension between legalism and antinomianism" (qtd. in 370). Mott finds, surprisingly, that the soon-to-be-rebellious Emerson 
held closer to doctrinal consistency with seventeenth-century Calvinism than either the liberal Unitarians or orthodox Calvinists of his day:

Young Emerson was more conservative than many of his fellow Unitarians in calling for a renewed awareness of the need for conversion by spiritual means. He was more liberal than Calvinists of his day in reviving the Puritan paradox that grace must be earned. (377)

In Nature and the series of formal addresses given over the next five years, Emerson lays out a metaphysics that continues this dialogue of tension between grace and works, and with a few switched terms we can see his doctrine of nature and the soul align closely with that of predestination.

Emerson begins his first sustained work, Nature (1836), which Miller calls the "pivotal utterance" of the Transcendentalist movement ("Introduction" 4), both by exemplifying and denying the meaning of the religion of "foregoing generations [who] beheld God and nature face to face; we, through their eyes." Emerson both wants to replicate and to replace this immediacy —an immediacy, of course, that the Puritans themselves would have vehemently denied (pace Hutchinson). Emerson appears both as an out-and-out Antinomian, asking for "a religion of revelation" rather than one of "tradition," as well as a revivalist of a lost tradition—one that was, to say the least, counter-traditional. But the direct revelation that Emerson aspires to is very different from the one Hutchinson claims in her trial, one much more focused on a transcendence of nature that incorporates grace into a discipline of works: "Let us demand our own works and laws and worship." By asking "to what end is nature?" Emerson is recreating in Romantic/Transcendentalist terms the tautological paradox of the covenants of grace and works 
—he is looking for an "end" to nature that is also an end through and beyond nature, transcending it but only through its immediacy, its revelation through its (and "our own") works. Thus, Emerson's reading of the "hieroglyphic" of man's condition is precisely through a predestined meaning inherent within and yet not born out by nature:

Every man's condition is a solution in hieroglyphic to those inquiries he would put. He acts it as life, before he apprehends it as truth. In like manner, nature is already, in its forms and tendencies, describing its own design. (7)

The covenantal structure of a predestined working out of grace is, ironically, provided here to Emerson as a model for the current generation to strike out on its own; Emerson's "theory of nature" is to strike out on a newly predestined path.

In the most famous passage of the book, Emerson transfigures himself into "a transparent eye-ball" in which "I am nothing" and yet "see all":

Standing on the bare ground, - my head bathed by the blithe air, and uplifted into infinite space,—all mean egotism vanishes. I become a transparent eye-ball; I am nothing; I see all; the currents of the Universal Being circulate through me; I am part or particle of God. (10)

Emerson enacts here his prior definition of "NATURE" as "the NOT ME" (8) while at the same time re-creating the self as the vector for and enactment of God, here not as gracious determiner but as a cipher of being. This one might call a new covenant or rather a dispensation of the covenant itself, where humanity may participate in God's free grace, "uncontained and immortal," unmediated by any structural framework or law-except the eyeball itself, of course, which remains as a husk containing nothing but the complete transparency of being. In this way, 
Bloom is correct in saying that "Emersonian Transcendentalism is not a transcendence at all, but is the program of attaining this transparency" ("Emerson" 561). Works is obliterated in the very enactment of and participation in grace, but remains nonetheless, haunting the framework as the framework.

The conceptual structure of Emerson's "theory of nature" begins with "Commodity," the benefits bestowed by nature and mankind's derivative improvements (one might say the political benefits of nature and society), both leading to the reciprocal "mercenary benefit" of an individual man's "work." Then, nature provides "Beauty," whose "constitution" is intrinsic, immediate, identical, "a delight in and for themselves," a "general grace diffused over nature" (13-14). By claiming that "[e]very natural action is graceful," Emerson matches nature with grace through inherent work, activity, perfectly aligned to one's inward "constitution"effectively, Emerson's constitution is the enactment of the tautological identity of grace and works that had already taken place within the covenant. The difference here is that, where in the past this created conflict, disagreement, discomfort, it has now been unified in a fauxAntinomian expression of unified Arminian utility and expression (16). Emerson creates an identity of grace and works through mankind's virtue being able to be equal to the virtuosity of nature.

Nature stretcheth out her arms to embrace man, only let his thoughts be of equal greatness. Willingly does she $\ldots$ bend her lines of grandeur and grace ... Only let his thoughts be of equal scope, and the frame will suit the picture. A virtuous man is in unison with her works, and makes the central figure of the visible sphere. 
Finally, when the intellect is able to receive the "actions" of Nature and transform them into art, it is through a differentiation of Nature's "sea of forms radically alike and even unique" (18). This radical identity of unique singularities under the attribution of beauty is, justifiably, called "universal grace"-a term understandable by way of Emerson's enactment of the intricacies and identities inherent in the Reformed Protestant tautology of grace as works in his vision of a gracious Nature.

But it is not enough to leave it there, for beauty must still be seen by the transparent eyeball of the artist as an act of "will" determined by the "first works," the covenant of works coming first, and the (unconscious?) "desire of beauty." In art, Nature works through the will of a man filled with the beauty of her first works:

The world thus exists to the soul to satisfy the desire of beauty. This element I call an ultimate end ... But beauty in nature is not ultimate. It is the herald of inward and eternal beauty ... It must stand as a part ... of the final cause of Nature. (19) Beauty, therefore, cannot stand alone as its own end, or cause, as its direction is all wrong — what is "the desire of beauty" but the inverse of the soul's desire for beauty, if the latter in fact truly exists? If the actions of nature work only through the gracious one-way determination of beauty's desire for the soul's satisfaction, we are left with a desire for precisely nothing, the nothingness of the soul, and synecdotal "part and parcel" of God. In a sense, the desire of the other cancels its own existence, obliterating nature in its own attempt to theorize itself.

Emerson's recovery of nature from beauty is through language, specifically through symbolism. Here we come to Emerson's philosophy as rescuing his aethetics, and providing Cavell with a perch on which to prop up Emerson and the American philosophical tradition in 
general. Emerson's philosophy of language uses simple symbolism to connect nature's spiritual insights directly to man's reason (a natural philosophy if there ever was one). The point to be made here is that Emerson's simplicity of language as a system of symbols directly connecting, as if by revelation, nature and mankind can be best understood, again, through the complex tautological root of the covenant motif. Thus, when reading the final element of the chapter "Discipline," one is ready for doctrinal instruction, for the determination of one's understanding by the precepts of nature. Nature, like the Puritan God, exemplifies a universal will and reason, yet now with mankind's full informed participation in its creation and execution.

Emerson's resolution of his metaphysics in the "Idealism" chapter is the identity of nature and the mind, of the "world in God," which simply accepts "the pure and awful form of religion in the world" $(32,39)$. Nature is "pervaded with human life," existing not around us but "through us" as a "projection of God in the unconscious," yet not subjected to the human will (41), and ends with a paen to equality, to the universal ability to comprehend nature's universal truths (489). As J. A. Ward points out, in Nature "'will' is both cause and effect, the beginning of the transformation and the ending" (499), adding a layer to Edwards's notion of the will as the effect of God's cause and then coterminous with freedom. Emerson's ideological work in Nature appears to resolve the conflicts in Reformed Protestant theology, except the ultimate conflict which is not meant to be resolved, as it is tautologically inscribed into the theological construct itself. Solving a tautology is merely repeating it, adding yet another tautology on top of itself. Thus, Cavell is only half-right when he claims that, "in Nature Emerson is taking the issue of skepticism as solvable or controllable whereas thereafter he takes its unsolvability to be the heart of his thinking" (112). Emerson's identification of Nature's works with God's grace merely 
repeats the tautology inherent in the covenantal identity of grace and works as found in Reformed Protestant theology; skepticism, as we will see, and as Cavell shows us, solves itself.

Cavell is an appreciative reader of Emerson's tautologies, making time in a detailed argument to point out the following pun in "Experience" as a "joking tautology": "I am thankful for small mercies" (147, merci means "thank you" in French). However, his analysis of this particular form of logical illogic in Emerson's work becomes more serious in his reading of "The American Scholar" (1837) — "the foundational text in American literary studies since the late nineteenth century" (Fuller 18) — and suggests that Emerson's text requires "conversion" and "aversion" to create identical acts of reading. Cavell identifies "a kind of tautology" in Emerson's "transfiguration" of inner to "public" thoughts through a slippage between the terms "illustration" and "illustrious," demonstrating that the "passage from private to public ideas is something open to each individual" (151). Here, the tautology is a democratic feint—open to all, but designed to be taken by only a few. The public is already suggested by and incorporated within the private, one's private (religion) being the condition(al) of the public (politics). This incorporation, Cavell says, "illustrates the conditions shared by humanity" but are "illustrious exactly because they are completely unexceptional" and yet fraught with "moral urgency," begging the question: "Is thinking ... something whose partiality or incentive is essentially moral and perhaps political?" (152). This transition and identification between the public and the private, as we have seen, has already occurred, has in fact been enacted, originally and exceptionally, through the political institutionalization of the covenant. The urgency is in the making of this condition unexceptional, truly available to all, but the covenant is not structured for such a guarantee, only suggestive of its necessity, its lack. Emerson, through Cavell's perceptive reading, expresses this complicated 
lacking at the heart of the tautology of public and private, which in order to function "requires both a constitution of the public and an institution of the private, a new obligation to think for ourselves, to make ourselves intelligible, in every word" (153). In contrast, the ultimate moral perfectionism of an individual is an antitautology, a self-difference rather than an identity:

Emerson's writing works out the conditions for my recognizing my difference from others as a function of my recognizing my difference from myself. (160) This fundamental difference within the self connects with the Žižek's Lacanian theory of the fundamental split within the subjective identity, a split that occurs prior to the subject's constitution, is in a very precise sense the constitution of the self. Žižek connects this subjective split with the gap in reality represented by the absent (lacking) God, a gap that constitutes the materialist reality as a necessary presupposition for the political. Cavell, fittingly, finds that Emerson's perfectionist view is not only "tolerable to the life of justice in a constitutional democracy ... it is essential to that life," but essential as much in its many failures as its few successes, with the individual always under threat of being "undone" by the "democratic demand for consent" (163-4).

However, Emerson leaves very little room for this differentiation to function within his idealistic framework, which identifies grace and works in the ultimate value he places on "the active soul," which is marked by its complete, democratic availability: "This every man is entitled to; this every man contains within him, although, in almost all men, obstructed, and as yet unborn" (57). Contrast the "American Scholar" scholar of "action" with the actual man (Emerson) of "Experience": 
Action is with the scholar subordinate, but it is essential ... The preamble of thought, the transition through which it passes from the unconscious to the conscious, is action.

Here, action (works) functions as the "preamble of thought," identical to the "transition ... from the unconscious to the conscious," as the medium for true or full understanding of the world, the "other me." This action/works state between unconsciousness and consciousness is "the raw material out of which the intellect moulds her splendid products," eventually by contemplation "detach[ing]" from "our unconscious life" and "instant[aneously] ... transfigured" into "a thought of the mind." Emerson goes on to describe the "impossibility of antedating this act" so that the act of intellection transfigures not just our personal histories but the substance of our individual selves:

So is there no fact, no event, in our private history, which shall not, sooner or later, lose its adhesive, inert form, and astonish us by soaring from our body into the empyrean. (60-1)

The phenomenon of intellect, the enactment of genius is the cause of the trans(pre)figuration of our latent or natural selves, so that the action of a scholar is to pre(con)figure the inert (unconscious) mass of life (experience) into a meaning it already has, all in order that it may soar "into the empyrean" of our true individuality, our genius.

One might say that this is simply a restatement of the phrase "thinking makes it so," but Emerson (unfortunately for Cavell) goes on to subordinate thinking to "living" which is required if one is to have "character": 
The mind now thinks; now acts; and each fit reproduces the other ... Character is higher than intellect. Thinking is the function. Living is the functionary ... This is a total act. Thinking is a partial act. (62)

Here we return to living, now consciously, but only as the dynamo of thinking and acting maintains the superstructure of character. The process of converting life through action into an intellect still subordinate to life yet now identified with the genius that created but no longer antedates it becomes the same Žižekian Möbius strip or short circuit of self-identification where one's genius must always be both being and becoming through a dynamic of action, conversion, and trans(pre)figurement. The result of all this Emerson calls one's "constitution" which maintains a "force" that cannot be contained. Even though Emerson ends with a strong statement of libertarian politics, pointing to the "new importance given to the single person," the sovereignty of the individual, and the hope for the future when a "nation of men will for the first time exist, because each believes himself inspired by the Divine Soul which also inspires all men" (70-1), it is a hope not supported by the determination of Emerson's structural constitution.

We now turn to the "Divinity School Address" (1838), Emerson's most direct and notorious engagement with Unitarianism (and, by extension, Reformed Protestant doctrine) since leaving the ministry. In the Address, Emerson is (re)creating an identity/tautology of nature and man in his theory of indivisible "opposites" where the "laws of the soul" are intuited and executed in one move:

The intuition of the moral sentiment is an insight of the perfection of the laws of the soul. These laws execute themselves ... in the soul of man there is a justice whose retributions are instant and entire. (76) 
The laws of nature and man become one law, the "law of laws," intuited from nature but identical with the moral sentiments of mankind and auto-executing due to their identical status with all potential and actual moral systems. The natural and moral system of law simply works, and is as unstoppable as it is limitless, is permanently situated within the mind of man ("man is made the Providence to himself ... the world is not the product of manifold power, but of one will, of one mind"), creates the "religious sentiment," and (to bring it full circle) is "sovereign over all natures" including the one from which we first intuit it. This radical unity of moral and natural law is in contrast to the systems of natural and moral law that John Winthrop expostulated in his "Charitie" sermon, where the covenant played a vital if complicated role in regulating between and tethering the divine and secular realms into a virtuous system of brotherly and holy inequality. Here, the religious sentiment provides a very different "foundation of society," one of radical and spiritual equality ("the foundation of all good ... in himself ... equally with every man"), foreclosing the role, even if the complications remain (77-8).

One such complication lies at the heart of this identification between the mind of man and divine morality, and the faculty of intuition: "Moral Nature, that Law of laws" (82). This radical unification, most evident in the closing lines, draws together into an identity all natural, moral, religious, and ethical laws-intellect, laws, grace, the world, the soul (92). It is this dynamic of radical unity that makes the Address, at first blush, sound like it could have been given by Ann Hutchinson, with its requirement of direct knowledge of the general soul, and its demand for purity of knowledge and connection to this spirit we all share but only a few know how to truly share it. This sense is reinforced by Emerson's jeremiad-like claim that "the universal decay and now almost death of faith in society" is because "[t]he soul is not preached," and bewails the 
passing of the Puritans, without any equal "public worship" taking their place which consigns an "equal right in the soul" to all parishioners. Emerson proffers, in place of the passing church, the soul as not just a new doctrine or polity, but an internalized and spiritualized covenantal relationship with oneself as the new organizing motif for religion that promises not just revival but "revolution": "Wherever a man comes, there comes revolution," i.e., a true man equals a true religion. In this revolution, one must "dare to love God without mediator or veil."

By foregoing models and mediators, one would think that Emerson, even more than Edwards, is finally dispelling the covenant and working directly with a free and self-fashioning grace: "Faith makes us, and not we it, and faith makes its own forms" (83-91). However, we find, in the final address considered here, "The Method of Nature" (1841), that Emerson does less foregoing than he claims. Here, nature is converted into covenantal themes when we "look at nature with a supernatural eye," look to its "cause" (126). Emerson invokes the Puritans, but says specifically that they, too, must be looked at differently, "seen in what they were, not in what they designed ... the spirit's holy errand through us ... sharers of a more sacred idea" (129). Scholars "stand for the spiritual interest of the world" and "must be a bringer of hope, and must reinforce man against himself," which I take to mean that he is dedicated to understanding the spiritual internal conflict within man, and to make that conflict operative. This reinforcement is within grace, which is within the "wit of man, his strength, his grace, his tendency, his art, is the grace and the presence of God." However, because "man, which is primary, does not yet exist," he perforce "turns to nature" for his spiritual meaning (115-8). Nature is "unbroken obedience," as "an ever novel effect" of a "cause ... from above ... a metaphysical and eternal spring ... a mysterious principle of life"-following Edwards, nature is not self-determined but predestined 
to "a universal and not to a particular end, to a universe of ends," plenitudinous, all equal, but not equal to itself, its own end, the "cause ... from above." In the end, the end of nature is not particular or private but eclectic and ecstatic, "it does not exist to any one or to any number of particular ends, but to numberless and endless benefit" (119-21), the very meaning of collective, but one that cannot perforce exist (remember, the cause comes before the effect). The forms made by faith are, in the end, empty.

Emerson is forced by his own metaphysical logic to describe nature in terms of free and determining grace, in a passage that is a tour de force of Emerson's conversion of covenant theology into transcendental logic. Here, Emerson describes man's "genius" in predestinary, elective terms, but generalized out of the specific theology to incorporate all epistemology: [T] he Grace of God seems the only description of our multiform but ever identical fact. There is virtue, there is genius, there is success, or there is not. There is the incoming or the receding of God: that is all we can affirm; and we can show neither how nor why. Self-accusation, remorse, and the didactic morals of selfdenial and strife with sin, is a view we are constrained by our constitution to take of the fact seen from the platform of action; but seen from the platform of intellection, there is nothing for us but praise and wonder.

We are limited to the either/or construction of predestination and irresistible grace, but instead of sin it is "our constitution" which is the limiting factor, aligned with action as well as remorse, and language. What directly follows the above passage is the final idealistic move from works to grace, which (perhaps disturbingly) constitutes a final action or solution: "The termination of the world in a man, appears to be the last victory of intelligence" (122). The "work" of nature is 
accomplished through an individual man's genius, the effect of gracious calling of the divine intellect infused throughout all of nature. The work is always "necessary" and a mediation between "two else unmarriageable facts" in nature: "[T]he union of foreign constitutions in him enables him to do gladly and gracefully what the assembled human race could not have sufficed to do" (123). Thus, the fusing of nature and genius, works and grace, becomes a graceful act of the fusing of opposites through obedience to the universal, unseen voice (124). For us to be truly an "individual man" or "soul" is to not be "recognized as individuals" but instead to be in ecstatic union with and reception of God's grace. However, in being related to the universal and not the particular, this "ecstatic state" is pure potential, "tendency" not "act": "This ecstatic state seems to direct a regard to the whole and not to the parts; to the cause and not to the ends; to the tendency, and not to the act" (125). In covenantal terms, it is one's state of grace that allows God to act through you, which are the terms of the covenant of grace and redemption. This ecstasy "is the law and cause of nature" which in turn "represents the best meaning of the wisest man" (127). As stated earlier in Emerson's essay, the genius of a true man presupposes and prefigures nature, reemphasizing that "tendency" is prioritized over "deed," and that obedience (tendency) must come before act, which is exactly, though anti-intuitively, the condition of the covenant of works, whereby the gracious transfiguration comes after the act of figuration, the shaping of one's intent to the preexisting intentionality of the divine. Grace, as it were, always comes too late, because it is always there already, the "multiform but identical fact" that predetermines whether "there is virtue, there is genius, there is success, or there is not." In this way, Emerson can say "we are constrained by our constitution" and yet hold it out as our only opportunityEmerson's reformulation of the Reformed Protestant covenant. 


\section{Third World of the Spirit - "Self-Reliance," "Experience," "Fate"}

Cavell suggests that Emerson provides a potential resolution to the "two worlds" duality of the determined natural and the free intellectual worlds, something he calls a "Third World of the spirit" (64-5). The poverty and the geopolitics suggested by this remark are aligned to Emerson's own more intrinsic construction of an ever-present "third party" to all human interactions in his essay "The Over-Soul":

In all conversation between two person, tacit reference is made, as to a third party, to a common nature. That third party or common nature is not social; it is impersonal; is God. (390)

Nature, here held in common both amongst ourselves as individuals and between the external and internal, corporeal and spiritual aspects of the universe is, simply, God, and is always already incorporated into Emerson's concept of one's dual "constitution." In this final section, we will explore how Emerson creates this alternative world (or three worlds, or a world in thirds) out of the conflicts inherent to his idealism, his final attempts to convert the theology of the covenant into what he calls "practical power."

\section{"Self-Reliance"}

Probably the most commented-upon of Emerson's essays, "Self-Reliance" has been praised for rescuing the American sense of self from the Dark Ages of belief to creating a "vision of the imprisoned imagination's chilling solitude" (Doherty 66; see also Wolfe). Bercovitch seeks to resolve this stand-off by distinguishing between a solipsistic "individualism" and a more participatory "individuality" working within the essay ("Emerson" 632) ${ }^{166}$-a distinction that

166 According to Bercovitch, Emerson preached "individuality," defined as "the belief in the absolute integrity, 
may be a difference, but only just. Thomas Joswick finds the "motives" or "strategy" of "SelfReliance" to be "to seek its justification ... in the domain of religious thought," relying on "the dynamics of what Emerson describes as religious conversion" (510n9); however, Joswick's Burkean "logological" analysis converts Emerson's rhetoric into an archetypal reading, which is not useful to us here. More aligned to our purposes, Ward criticizes Emerson's definition of the free self through the tautological definitions of God and self and the beginning and ending of the conversion process (499). Lou Ann Lange takes up this argument, finding that Emerson's "tautological reasoning" and his "collapsing the distinction between means and ends" did not lead to "privatism" but instead demonstrate "the limited, or 'necessitated,' nature of true liberty" through an "act of obedience" to the universal moral law: "man's utter obedience was the necessary prerequisite for his perfect freedom — the freedom to obey only himself" (xxi). Cavell, however, separates himself almost completely from this discourse on individualism and privatism, seeing instead in "Self-Reliance" a "study in writing" that rises to the level of theology, namely, the right to one's "Whim" to use God, or any other word, seriously. In the end, in a choice analogy, "words are no more ornaments of thought than tears are ornaments to sadness or joy," by which he means "expressions are the last things to take at face value." Language, as Emerson likes to say, is in the end symbolism, but is also symbolism as ending, and the finding of one's own ends (54).

Read literally (a tautology in and of itself), Emerson's famous definition of genius relies on correspondence not only between man and nature but between man and man, a

spiritual primacy, and inviolable sanctity of the self," which Bercovitch is careful to distinguish completely from the political "systemic individualism" of liberal democracy, the Romantic rebuttal to Enlightenment bureaucracy. 
correspondence that requires the guarantee of a mutual response, both from and to others, a complete recognition that doubles as reconnaissance:

To believe your own thought, to believe that what is true for you in your private heart is true for all men, - that is genius ... In every work of genius we recognize our own rejected thoughts: they come back to us with a certain alienated majesty.

There are two phases in this recognition, one an assurance in the form of belief that 1) I think, 2) my thoughts are true, and 3) my thoughts match others' thoughts truth for truth. Later in the essay Emerson chides his contemporaries for no longer daring to say "'I think,' 'I am,'" which Cavell points to as a signal moment in Emerson's development of an American philosophical answer to European skepticism (270, "Being Odd, Getting Even"). However, the skepticism is not just ours, but Emerson's, and not just in his chiding, but in the "private heart" that requires belief not just in itself but in the truth (and thought_-Emerson's questioning of his readers claim to their own thought) of others. Even more so, the second phase of this recognition (though, as we have seen, it should probably be first) begins with "rejected" thoughts and an "alienated" majesty, both reclaimed not through the automatic execution of the "Divinity School Address" but through a "work of genius." One's work, one's writing and philosophy, becomes a marker to the distance between ourselves and our birthright, our self-alienated majesty, a distance as deep as the old doctrine of original sin that made the covenants of works and grace necessary. A certain skepticism (works) is built into the most radical idealism (grace).

As discussed earlier, there is a fundamental consistency built into the core of Emerson's thinking, in that self-reliance is tied to one's predestined placement in the world. This is a 
remarkably positive but no less Calvinistic conceptualization of freedom, in that one is only free when one fully accepts and lives out one's place in the world, one's "transcendent destiny":

Trust thyself: every heart vibrates to that iron string. Accept the place the divine providence has found for you. (260)

Emerson is very much recoloring Edwards's configuration of freedom as the working out of a predetermined fate, as the freedom to be who one actually is and to act accordingly. The self one is to trust is the self that has been given to you; for Edwards, you are free to follow your will (you actually have little choice in the matter) because it is the effect of a higher (or lower) cause. We can go so far as to say, in terms of Reformed Protestantism, that both metaphysical systems are based on the theology of irresistible grace, and only differ on the perseverance of the saints, the doctrine of election. Emerson, in fact, here develops a new strain of Reformed Protestantism in combining universal election with individual choice, creating a theology where one is both guaranteed and uncertain about one's status of salvation at the same time. From this perspective, one is a bit more sympathetic about mankind's timidity, in that one must be both a nonconformist and conform to one's "transcendental destiny" without following a false, socialized path.

We are left with a society that is unsocialized, that is unified in its opposition to its own constituents, more specifically to the quality (manhood) that is shared by each of its constituent parts but not by the whole: "Society everywhere is in conspiracy against the manhood of every one of its members." ${ }^{167}$ The obvious questions is, what is this society? Where did it develop, if not in nature? The answer comes in the next sentence, which provides a logic at once mercantile, socialistic, and barbaric: "Society is a joint-stock company, in which the members agree, for the better securing of his bread to each shareholder, to surrender the liberty and culture of the eater."

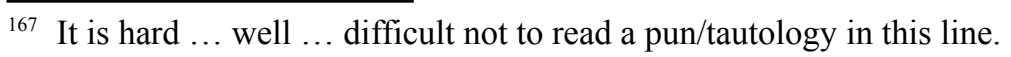


This conspiracy, in the form of a social contract for the economic betterment of its members, comes under what Emerson sardonically calls the "virtue" of "conformity": "The virtue in most request is conformity. Self-reliance is its aversion ... Whoso would be a man must be a nonconformist" (261). Cavell bases much of his claims for Emerson's philosophy on the above middle sentence, or an "implied" version of it ${ }^{168}$ as he contextualizes in "Emerson's Constitutional Amending":

Emerson characterizes thinking as marked by transfiguration and by conversion ... causing understanding or illumination on par with that of religion - the religion always under criticism (held in aversion) — in Emerson's thought. My claim is accordingly that the implied sentence "Self-reliance is the aversion of conformity," when itself subjected to the operation of transfiguration and conversion, means something like: To think it to turn around, or turn back ... the words of ordinary life ... that now repel thought, disgust it. (191)

While Cavell's purpose is to make a place for Emerson at the beginning of a (re)turn to ordinary language philosophy, I wish to dig deeper into "the religion always under criticism (held in aversion)" that Cavell senses behind the "action of words." First, and most obviously, what religion most fits this description, "always under criticism ... held in aversion" but Calvinism?

For Emerson, Unitarianism perhaps more closely fits the bill, but Cavell's reference is (or should be) clearly directed toward the conflicts and promise within the "nonconformist" Reformed Protestant tradition. Second, the (trans)figuration and conversion identified by Cavell, as we

${ }^{168}$ Cavell added the word "implied" to this passage in the version collected in Emerson's Transcendental Etudes, in all likelihood in response to Barbara Packer's critique in "Turning to Emerson." Besides noting that Cavell misquoted Emerson's original line ("Self-reliance is its aversion" [261]), Packer disagrees with Cavell's interpretation of "conformity" being the antecedent to "its," pointing to the use of "aversion" in nineteenthcentury slang as a reference to society (55). Yet her new reading says much the same things, as Cavell and Emerson both appear to be using society and conformity interchangeably. 
have seen, already holds within its processes the aversion and criticism from within (one is always, by definition, under self-criticism within Reformed Protestant theology)—a dynamic always already translated to within the self, to the self-doubt at the heart of the radical idealism carried within the Reformed Protestant theology of "free" grace. This makes conformity, the attempt to form with others under a structure of belief, a religion, a church, already a self-averse process where transfiguration and conversion of form becomes an almost automatic process of division, of super-nonconformity (the permanently unsettled status of the covenants: grace vs. works, redemption, half-way, renewal, church, national, etc.). One could say we are doomed to be Puritans, and not very good ones at that.

Emerson makes a distinction between actions that are thought to be excellent and "what I must do." This comes across as an apparent contradiction between Emerson's "refus[al of] this appeal from the man to his actions" and, a few paragraphs later, his own appeal to "do your work, and I shall know you" (263-4). Isn't he asking us to show us our work? How is what he thinks different from "what the people think"? A possible explanation presents itself in the famous line that soon follows: "A foolish consistency is the hobgoblin of little minds, adored by little statesmen and philosophers and divines" (265). Teachers of Emerson mostly focus on the first line of this near-rhyming couplet, and quickly point out that not all consistency is condemned but only the foolish sort. But the second line, tied directly to the first, draws the focus not just to the foolishness but to the diminutive dimension of the intellectual representatives of political, scholarly, and religious institutions. This is contrasted, again dimensionally, by the equally famous line: "To be great is to be misunderstood." In short (so to speak), the definition of greatness is one's both lacking and fulfilling one's dimensions within the 
structural forms of one's role in society, maintaining what is right after one's own constitution (262) but maintaining a constitution nonetheless. Thus, it is perfectly consistent for Emerson to go on and appeal, not to randomness and chaos, but to a higher order and consistency, tying history and institutions directly to individual manhood:

$[T]$ he fact which is the upshot of all history, that there is a great responsible Thinker and Actor working wherever a man works; that a true man belongs to no other time or place, but is the centre of things. Where he is, there is nature ... An institution is the lengthened shadow of one man ... (267)

This is similar to Edwards's higher cause that motivates our wills which are then free to follow their predetermined whim. "Nature" becomes the higher standard for true manhood. Emerson may be spouting European Romanticism, but the conceptual context of his thoughts is definitely American and, more specifically, Reformed Protestant.

"If we live truly, we shall see truly. It is as easy for the strong man to be strong, as it is for the weak to be weak" (271). These simple and reassuring tautologies lead into a more profound and basic, less affected, description of what Emerson calls "the highest truth," which is achieved "not by any known or accustomed way," is "wholly strange and new," and even "exclude[s] example and experience," giving way to a state of being that purely and dispassionately "beholds identity and eternal causation, perceives the self-existence of Truth and Right, and calms itself with knowing that all things go well." This reassurance and knowledge comes at a price, in that the soul dispossesses itself from familiarity and merely "becomes" a being dispossessed of the self, an un-selved self, a zombified being, not a prepossessed "reliance" one's self can possess but "that which relies, because it works and is." This leads, inexorably, to the final identity, "ONE," 
which subordinates (contrary to promise) "self-existence [as] the attribute of the Supreme Cause." We are, shockingly, back in Edwards's Freedom of the Will, determined not by Lockean logic but by Coleridgean idealism to match our will with perpetual causation. This is the ultimate unfolding and expression of halting starts and unnerving counter-arguments of the early Puritans through Edwards.

In his penultimate declaration of transcendental rights we find, in short, all the elements of Emerson's resolution of the covenant formulary:

Be it known unto you that henceforward I obey no law less than the eternal law. I will have no covenants but proximities ... I must be myself. I cannot break myself any longer for you, or you. (273)

It posits an eternal law as the law under which he will be regulated, pledging obedience to this law (and the lawgiver, who is himself), and striking/breaking all other oaths but this one, which is both equal to himself and beyond anything touching himself. While the context of this oath is domestic, the leaving behind of family, it should be noted that the final point of the essay is a political one, in that "a greater self-reliance must work a revolution in all the offices and relations of men" (275). These differing topographies resolve themselves in the fundamental tautology of contradiction, "Every great man is a unique," later described as a "singular equality" shared among great men regardless of time period — a greatness that knows no improvement (279-80).

Cavell, however, does in fact improve on Emerson's mode of greatness, or at least provides a new and improved topography outside the home or congress, namely that of writing as philosophy, as self-authoring "in which the uncreatedness of the individual manifests itself, in which human life appears as the individual's failure at self-creation" (89). Emerson, according to 
Cavell, introduces the possibility that one can not only not be great but not exist simply by not thinking (vs. Descartes), and therefore can haunt the world by one's non-existence, similar to Žižek's appeal to Christ's "monstrosity." While Cavell claims this situation to be more literary than philosophical ("at some stage the philosophical becomes, or turns into, the literary" [87]), I would argue that this undead dimension, besides buttressing skepticism and populating popular literature, is essentially both theological, a status of the soul's lack of self-identity, and political, being claimed for a whole society. But the problem goes further than that, suggesting that even the theological dimension needs to be reworked, theorized:

[T]he problematic of enacting one's existence skirts the edge of metaphysical nonsense ... as if, if I am not a ghost, I am, I would like to say, worked, from inside or outside. (88)

This "working" from the inside out, this calling from within oneself, is key to Cavell's understanding of "Self-Reliance." Cavell claims that one's work is to read and be confronted by Emerson's words, to "find yourself known by them" through a constant struggle with them —"when you stop struggling with Emerson's words they become insupportable" (97). ${ }^{169}$

Cavell's attention to "aversion" ("Self-Reliance") and "antagonism" (as we will see in "Fate") leads directly to politics as a literary mode of self- and other-creation, all based on a promise (covenant) of companionship, a promise that at the same time cannot be guaranteed -is not a firm commitment, can be broken by either party—and forms the basis for the positive attributes of politics_-"liberty and equality." Emerson is, in Cavell's literally vital reading, a guarantor of the effect of American politics caused by the literary, inherently unequal covenant:

169 My reading, colored by the world of Reformed Protestant theology and Žižekian theory, is interested by the footnote that says Emerson's prior draft had "do your thing," making "work" a Lacanian thing that functions theologically rather than practically, under the "promise" (Cavell's term for this phrase) to co-exist in language. 
$[\mathrm{P}]$ olitics ought to have provided conditions for companionship, call it fraternity; but the price of companionship has been the suppression, not the affirmation, of otherness, that is to say, of difference and sameness, call these liberty and equality. A mission of Emerson's thinking is never to let politics forget this. (108-9)

The "price" of what Cavell suggests as the literary creation of politics is exactly the tautological drive of identity, of lack of (our universal) otherness, that we have been describing in terms of the covenant motif. One is always at risk of becoming truly equal to one's companions, which is the same thing in Emerson's ideology of solitary individuality as becoming utterly alone. Cavell suggests, in the end, that American literature is both punishing and forgiving philosophy for thinking it was other, and that the melodramatic performances of the self in literature are the "sole proof of its freedom and its existence," accomplishing the ends of philosophy and, perhaps, of theology.

\section{"Experience"}

Cavell's project is to see in ordinary language philosophy and the Transcendentalism of Emerson and Thoreau a general response to skepticism by, ironically, preserving it by way of the act of contesting fundamental beliefs, the contesting and the mourning of the loss of belief being the beginning of philosophy (34-5). Cavell makes much of the dialogue between founding and finding in "Experience," the insistent necessity to find ourselves in order to found a national self. The famous beginning of Emerson's essay on the stair points to the indeterminacy and lethargy of his culture that does not have the ability to account for itself: "How many individuals can we count in society? how many actions? how many opinions?" (472). Emerson directly implicates 
himself in this lethargy and inability to connect and count by describing his lack of grief for the loss of his son, which leads him back to a more skeptical view of his larger theme of nature: I grieve that grief can teach me nothing, nor carry me one step into real nature ... I take this evanescence and lubricity of all objects, which lets them slip through our fingers then when we clutch hardest, to be the most unhandsome part of our condition ... Our relations to each other are oblique and casual. (473)

Emerson, here and in what follows, directly associates society with objective nature, and theology with temperament, interpreting our personal and corpulent natures to have "the veto or limitation-power in the constitution" over social and spiritual relations - that is, until the "intellect ... intervenes" and dispenses with the "nightmare" of indeterminacy, permanently, so that we "cannot again contract ourselves to so base a state" (475-6).

This opening drama of the essay "Experience" and of experience in general is meant to be instructive of the limitations of both science and religion. Temperament is described as an "iron wire" that "prevails over everything of time, place, and condition, and is inconsumable in the flames of religion," and "puts all divinity to rout." But, as Emerson objects, "the definition of spiritual should be, that which is its own evidence," meaning that what is truly spiritual should not be beholden to one's unhandsome condition of being unable to grasp real objects, but should instead rely on its own self-identical reality. The tautology or identity of the spiritual condition with itself is the guarantee, the necessary condition, of Emerson's entire metaphysical, idealistic structure. One must be at one with oneself: this is the "original equity" on which one's constitution is based, and is able to regulate (and be regulated by) one's temperament in the "time, place, and condition" of experience (474-6). 
After outlining the "golden impossibility" of man in the excesses and superabundance of the now "powerfully oblique" and radically externalized nature ("the world is all outside; it has no inside"), Emerson, in a feat of intellectual and theological synthesis, draws together the impossibilities of skepticism and and the guarantees of idealism, using (unconsciously?) covenantal terminology:

Every man is an impossibility, until he is born; every thing impossible, until we see a success. The ardors of piety agree at last with the coldest skepticism,- - that nothing is of us or our works, - - that all is of God. Nature will not spare us the smallest leaf of laurel. All writing comes by the grace of God, and all doing and having. (481-3)

The very impossibility of humanity is its place in the natural world, the impossibility of internal integrity its guarantee of priority in the purely external world (remember, in Nature genius comes before nature), and the full skepticism of mankind's condition, the lack of identity between man and his work, is the (miraculous and monstrous) proof of grace's existence throughout our works, so that the lowliest acts and existence of man's experience are proof of an eternal cause and motive to act. In theological terms, the covenant of works is the mode of being for the covenant of grace, its activity as well as its "laurel" of victory.

In this way, Emerson is able to redefine the meaning behind religion, as more formal than historical (though my argument is that it retains its history of forms), again assuming or infusing skepticism into the formalism of religion:

Life has no memory ... So is it with us, now skeptical, or without unity, because immersed in forms and effects all seeming to be of equal yet hostile value, and 
now religious, whilst in the reception of spiritual law ... they will one day be members, and obey one will. On that one will, on that secret cause, they nail our attention and hope. Life is hereby melted into an expectation or a religion. (484) The multiplicity of hostile religious forms (denominations, expressions) Emerson transfigures into an expectation of a future religion of membership, of a conversion of constituent and hostile parts into an indiscriminate whole, what he later calls "this new yet unapproachable America" worshiping the "unbounded substance" and "ineffable cause" of a "national religion." By being placed in the future, this religion of life loses not just its memory and historicity but also its present tense: "Our life seems not present, so much as prospective." The futurity of belief is then reinvested into the past, and into the definition of belief, or religion, as well as into the material history of human experience: "[I]t is not what we believe ... but the universal impulse to believe, that is the material circumstance, and is the principal fact in the history of the globe." Emerson's play is to capture the skepticism of material existence, the transience of temperament and unhandsomeness of objective reality into his naturalistic yet futuristic metaphysical structure overlayed onto his past idealism of nature, so that "out of unbeliefs a creed shall be formed" (485-7). Belief, in the end, incorporates skepticism or unbelief.

Cavell is correct to see that "Experience" is "about the epistemology, or say the logic, of moods," its argument about the "very evanescence of the world proves its existence to me; it is what vanishes from me." Cavell argues against Emerson as a solipsist (even, at times, against Emerson, which is a necessity), showing that he is instead "out to destroy the ground" beneath the subjective/objective formulation. This he calls Emerson's "state of 'romance' with the universe"-we do not possess it, but our life is to return to it, to respond to its contesting for my 
attention $(11,13)$. Cavell suggests (as does Emerson), that the answer to skepticism is in "reconceiving its truth" (16) by confirming the lack of certainty in regard to existence, but receiving and acknowledging that existence nonetheless: "This departure, such setting out, is, in our poverty, what hope consists in, all there is to hope for; it is the abandoning of despair, which is otherwise our condition" (19). Cavell directly connects the poverty in which we find ourselves to Emerson's founding of philosophy specifically on finding this skepticism in the "contradiction, the countering of diction, [which] is the genesis of his writing of philosophy" (113). Cavell parses out the inherent contradiction within Emerson's terminology, which we should note is inherently theological:

The conditions of the concept of condition will thus form part of what the word "condition" itself says ... "Aversion" is one of Emerson's Emersonian words for countering; it is roughly his word for what others call "conversion" ... (113) In the end, consistently with his other "findings," philosophy is claimed for American culture by Cavell prior to its inheritance through Emerson: "[P]hilosophy, as part of culture, can only be inherited by a nation that already possesses that part of culture known as philosophy" (115). Cavell, immediately after this statement, identifies "Experience" as staking Emerson's claim to something like the inheritance of philosophy ... a first inheritance," yet this appears to contradict Cavell's prior finding of a prior founding, a founding as it were prior to the finding of philosophy in America. Thus, his conversion is "turned around, reversed," converted to aversion, "the condition under which anything new can be said" or written, which also exists in the condition (as does America) of being "repellent, or say unattractive; and it means that America so finds this 
writing," and itself, as "unapproachable": "Emerson's writing is (an image or promise of, the constitution for) this new yet unapproachable America" (121).

For Cavell, and for this study, Emerson's work stands as the acceptance of the contradictions inherent in America, in writing, and (I argue) in the covenant. The conversion he effects on the covenant is in making its contradictions into a positive attribute of American ideology — a decenteredness that is inherent and yet ineffably leads (concentrically) to a fundamental unity, or oneness, an identity, if not an equality, with each other and with God.

"Fate"

"Fate," the last of Emerson's essays that we will consider, most directly addresses the themes of Edwards's Freedom of Will, both in terms of its exploration of determinism and predestination — what he calls "irresistable dictation" and "beautiful limitation"—and its disquisition on the proper role of "practice" in the transcendental realm of the intellect. Cavell, in two readings of this essay ("Emerson, Coleridge, Kant" and "Emerson's Constitutional Amending"), situates it within Emerson's political activism concerning slavery, a reading that has been supported by other scholars. ${ }^{170}$ Lawrence Buell finds that the "double consciousness" expounded in "Fate" leads both to an "ethically robust activism" and a lack of clear direction: For better and for worse, the essay has never been able to make up its mind as to whether to conceive of fate monistically or dualistically: as freedom's antagonist or as Emerson's old friend "compensation" in disguise (24)

\footnotetext{
${ }^{170}$ Buell finds a stronger argument than Cavell's in directly connecting "Fate" to Emerson's abolitionist activism in the rhetorical parallels between his political and speculative writings and the documentary evidence of Emerson's journals as sources for these writings ("Emerson's Fate" 20-1).
} 
As Lopez argues, Emerson's is continually reworking in his later work his past ideas, his "vision of life as a theater of conflicts" and "antagonisms" (257). One might say, to both disagree with and to push Buell and Lopez to the limit, that the ethical force of Emerson's concept of Fate is its positive indeterminacy, similar to Melville's Bartelby joinder, "I prefer not to"— an affirmation of a position of negation, a negative action. This is not so much "cosmic bemusement" but direct engagement with the difficulties of political engagement.

Emerson demonstrates from the start a remarkable affinity to determinism without any conflict to personal liberty:

But if there be irresistible dictation, this dictation understands itself. If we must accept Fate, we are not less compelled to affirm liberty, the significance of the individual, the grandeur of duty, the power of character. This is true, and that other is true ... We are sure that, though we know not how, necessity does comport with liberty ... the riddle of the age has for each a private solution. (769) These vague affirmations, based only on an asserted communal intuition, resolve themselves through tautological oppositions which are proven through practical experience, depth of feeling, and a dignity that again hearkens back to the "Calvinists" of past generations. However, later Emerson defines "fate" in a way that contrasts with Edwards and carries forward political themes from "Politics" and "New England Reformers":

Providence has a wild, rough, incalculable road to its end ... An expense of ends to means is fate; - organization tyrannizing over character. (772)

Though using theological terms like "Providence," his definition is purely structural, or structure with a moral twist. For Emerson, "ends"—-the stuff of tautological systems, this being defined as 
that - is done away with, tyrannized and expended away by "means"; to put it in the language of causation, fate for Emerson is the triumph of cause over effect. For Edwards, this is simply an obvious identity of Providence and the First Cause, but for Emerson the moral compass points to human rather than divine qualities or attributes - instead of God deferring mankind's destiny, collective or bureaucratic "organization" managerially circumscribes one's character" with "irresistible dictation." The great covenantal controversy becomes the office politics of a scrivener.

Emerson goes on to talk about the determination of function to form, and circumstance to livelihood, up to and including whole classes and races of humanity. This, in the end, is "constitution" (773) — one's individual self as determination, as destiny. It is one's preordained covenant, written, signed, and sealed before one was born, or more specifically through one's birth. However, fate has its own limitations, or limits on its limitations, from power and free will, existing in a "dual world" with "power": "If Fate follows and limits power, power attends and antagonizes Fate." This antagonist dual (and dueling) world defines "Man" who is himself "a stupendous antagonism, a dragging together of the poles of the Universe." Free will, on the other hand, is combined to fate not through antagonism but through identity and tautological definition: "To hazard the contradiction,-_freedom is necessary ... a part of Fate is the freedom of man." That part is "Man Thinking" which, as we have seen in past essays, is the essential function of mankind, the mode of being. Mankind is, in this formulation, compelled to be free, "to look not at Fate, but the other way: the practical view," away from the fatalism of nature (779). 
Seemingly through this fatal yet positive link of identity, man is called by Emerson to "confront fate with fate" and take on its most salient qualities, first through "Thought" which allows us to "speak for Nature" and "against ourselves" by situating ourselves inside our own insight: "It is not in us, but we are in it" (a general and important theme throughout Emerson's later writings). This priority of thought to self allows the will to take on a higher purpose, to "will that which must be" through the "will of all mind [which] is poured into the souls of all men, as the soul itself which constitutes them men." This complete identity of general will, soul, constitution, and thought sublimates or "dissolves the material universe," and yet succumbs to the reality of unequal providence from one mind to the next: "Always one man more than another represents the will of Divine Providence to the period." The sublimity of full unity in the general will still expresses itself in a very different "practical power" from one person to the next. Power, in the end (and only the end), lies in the tautology of fate and freedom, a tautology always already destabilized, open to the tyranny of contingency. One can have a covenant that resolves fate and freedom, contractually obligates the omnipotent and the lowly, but only if the contract is fatally flawed from the start. In this way "power" eventually "throws us ... against ourselves." It is through one's lack of self-determination that one can be truly self-determining, individual, free-freedom comes through an investment in one's contingent and subservient situating to one's actual power: "it is not in us, but we are in it" (780-2).

The second element needed for freedom is "moral sentiment," which when fused with thought/insight "generate[s] the energy of will." This process is described as a "conversion" but in fact operates as the creation of an identity/tautology between man and will: "There can be no driving force, except through the conversion of the man into his will, making him the will, and 
the will him." This will then becomes the "one serious and formidable thing in nature," an impersonal, immaterial being that we participate in but do not become; it is the impersonal true nature of personality, the being of oneness with the universe which we are all a part. Emerson takes will not as an inherent attribute of freedom — man must be "conver[ted] ... into his will" (782-3). This is very different from Edwards's will as the simple attribute of freedom. Ultimately, the "limitation" of Fate is allowable if it supports the formation of a truly willful man.

Fate, later in the essay, is defined (again) as "facts not yet passed under the fire of thought; - for causes which are unpenetrated" (784). Here, fate is not the triumph of means over ends, but merely the holding action while moral ends catch up. If we take the alignment of means/nature/works and ends/power/grace, we find that they are not exactly aligned, as grace also functions as the means of God's determination of salvation, whereas works are the ends of the law. This misalignment, this troubling of Emerson's dual world from within, is yet another "unpenetrated cause" with which his (and Cavell's) theory of moral perfection will have to contend. Emerson's rather pitiful and, at times, frightening societal analogues - the "imperial Saxon race" and the like - display the difficulties of his structural/theoretical maneuvers to situating heroic freedom within a metaphysical destiny. The evolution of mankind to greater individual liberty and freedom is a marker for Emerson of the "ascending effort" of the universe, described often in racial terms. Nevertheless, these unfortunate examples only illustrate the hidden conflicts within Emerson's ultimate expression of American supremacy: "Liberation of the will from the sheaths and clogs of organization which he has outgrown, is the end and aim of this world" (786). As we found earlier, in this and in prior chapters, the will is shot through with 
theological "sheaths and clogs of organization," the covenant concept being only one example, the new "constitution" being another.

But we still have the problem of the "constitution" of mankind—is it a help or hinderance? is it tied to fate or bent toward freedom? Emerson seeks to illustrate "how fate slides into freedom, and freedom into fate" as one potential answer, demonstrating that the necessities of nature breed the necessary freedoms of life to live: "As soon as there is life, there is selfdirection ... Life is freedom ... Life works both voluntarily and supernaturally in its neighborhood." This leads to the necessary "tie between person and event" which, as expected, are tied together by tautological definitions, the mystical qualities of cause and effect, and one's constitution:

$[T]$ he soul contains the event that shall befall it ... What each does is proper to him ... we have not eyes sharp enough to descry the thread that ties cause and effect ... The tendency of every man to enact all that is in his constitution is expressed in the old belief, that the efforts which we make to escape from our destiny only serve to lead us into it. (787-90)

Emerson clearly does not offer us a way out of this, except to celebrate "Beautiful Necessity" and to be aware of our "double consciousness" which requires man to "ride alternately on the horses of his private and his public nature." This dual-focus public-private identity, irresolveably tied to each other in what Emerson calls a "Blessed Unity" (but we might more accurate characterize as the conflicts of the covenant), can be seen in the end where Emerson blatantly contradicts his earlier claim that "I will have no covenants but proximities" with the claim, from "Necessity," that "there are no contingencies", and that a higher "Law" resolves all conflicts (792-4). 
"Fate," perhaps more than any of his other essays, sets up Cavell's concerns regarding the political nature of his philosophical reading of Emerson, of reading Emerson's nature into American philosophy, as America's philosophy. In his first sustained reading of "Fate," Cavell finds the essay "excruciatingly difficult to come to terms with." He does so, however, by calling out "condition" as a "key word" in the essay, denoting "something mysterious ... in human life," requiring as it were its own conditions, "the conditions in human thinking underlying the concept of condition" which take the form as "criteria," "agreements," "conspiracies," and finally "knots of agreement (or conspiracy) which philosophy is to unravel." Cavell connects this to the conditionality of language (etymologically con-diction, or "talking together"), and to "terms, stipulations that define the nature and limits of an agreement, or the relations between parties, person, or groups." The connection to the conditionality inherent in, yet obviated by, the concept of the covenant in Reformed Protestant theology is, of course, suggested here. Put together, the terms of these agreements are part and parcel of the "irresistible dictation" of Fate, resulting in our fatedness, or determination, functioning like a text, that "language is our fate":

[W]ith each word we utter we emit stipulations, agreements we do not know and do not want to know we have entered, agreements we were always in, that were in effect before our participation in them.

Thus, the textuality of life becomes part of our alienation, distancing us from our own lives (it is hard, as the Puritans could tell you, to live your life as if it were an agreement), as well as our direct connection to "economic and political powers," also expressed by "terms." All of this leads to the "antagonism," what Cavell calls a "philosophical joke, a terrible one" at the heart of 
Emerson's essay (and ourselves), in that "fate is the exercise of this same capacity [to give law to ourselves], so that fate is at once the promise and the refusal of freedom" (70-3).

This promise of freedom as coterminous with one's fate is the exact theological point Edwards makes in Freedom of the Will. Cavell claims for Emerson the philosophical work of destroying our "past solutions to these mysteries," which are in fact our "intuitions," and requiring us to "asse[ss] which of our intuitions are satisfied, and which thwarted, by the various dramas of concepts of figures like fate, and freedom, and foreknowledge, and will." This, Cavell claims, is part of Emerson's (and our) "project to trace out the source of our sense of the world as independent of us, for only then is skepticism a problem" (69) — a problem welcomed in the Emersonian text.

Cavell spends much of his time on Emerson feeling him out in terms of finding in him the founding of American philosophy. Immediate political considerations are an afterthought (an amendment?) marked by their reintroduction into his reading of "Fate" in "Emerson's Constitutional Amending." But by politics, Cavell is distinctly discussing issues ("this founding matter of slavery"), not theory, and we are left to wonder how Emerson's philosophy impacts political thought. For an answer, we track back to Cavell's discussion of Emersionian "thinking as marked by transfiguration and by conversion" which, as an "action of words," stand "on a par with that of religion — the religion always under criticism (held in aversion)—in Emerson's thought." Religion, or more precisely theology, stands as the "founding matter" of Emerson's philosophy and politics, and its ghostly historical presence should be considered as part of the "founding of American thinking" represented by Emerson. We can understand, then, why Cavell's question on the "kind of writing — philosophical? political? religious? — takes the form of 
the prophetic prose of 'Fate,"' finally calling it "a philosophical enactment of freedom." Cavell is looking to Emerson to establish a basis for an American belief system, a belief in America as a "culture of thinking" that lives out in its politics of freedom. ${ }^{171}$ Thus, we come full circle in our reading of covenant through our pre-reading of America's political idealism causing itself (196, 193, 196-7).

It is to this American belief system, in ourselves as individuals and as a society, that Cavell refers when he claims that "Emerson identifies his writing ... as the drafting of the nation's constitution; or, I have come to say, as amending our constitution" (208). What Cavell calls Emerson's "constitutional judgment" (209) allows for the ethical amending of universal ideas and valued by each individual. Emerson recognizes that, for his words to have power, they can not be claimed as his own, but must be representative, constitutive, "exemplary" of a larger power:

The power he claims for his words is precisely that they are not his, no more new than old; it is the power, I would like to say, of the powerlessness in being unexceptional, or say exemplary. (202)

This Cavell later describes as Emerson's "transfiguration" of the words "my constitution" to incorporate both the individual "condition" and the corporate conditionality - "a structure at once of the soul and of its society" (212). These private and public categories are at the same time necessary (as both moral and physical necessity) and immaterial— the same as theology and politics, both incorporating both realms. Emerson incorporates this private/public paradox into a literary theory incorporated into the political idealism of American exceptionalism:

171 This is what we might call a softer version of the "supremacism" discussed in the introduction to this study, and perhaps truly can be viewed as one of its sources. 
The power he claims for his words is precisely that they are not his, no more new than old; it is the power, I would like to say, of the powerlessness in being unexceptional, or say exemplary. (202)

This, one might say, is the founding of American philosophy on a literary politics that is remarkably similar to Puritan typology, in that one is only "exemplary" when exemplifying what comes before- in other words, when one is being "unexceptional," unoriginal, avoiding "innovations," certainly not founding anything. Slavery cuts to the very heart of the American claim to and basis for its belief in itself, the philosophy of its own existence

America's claim to its own culture of thinking as its success in ridding itself of the institution of slavery will be [fateful] for establishing its claim to have discovered a new world, hence to exist. (196)

This leads directly into his thesis, that Emerson performs the "philosophical enactment of freedom" in demonstrating in his writing "the necessary siding against fate toward freedom that is the condition of philosophical thinking" (197). Words thus become our mode of ethical (political) action, the self-reliance of words against the conformity of society. Philosophy can, thus, only exist (as a call) against slavery by its very existence. Emerson's writing, then, is his philosophy, and thus the expression of freedom, political or otherwise.

In a later essay ("Old and New in Emerson and Nietzsche"), Cavell claims that Emerson's "conditions and contradictions of speech" constitute "the discovery of free speech" (231), the ability to contradict one's own speech is freedom. One must ask, finally, is such a freedom necessary? Is there a necessity behind Emerson's writing, a metaphysical reality behind Emerson's practice, his "work"? Yes, but also no—-his work, like the covenant of works, 
predicates its own metaphysical necessity, and creates the (necessity of) grace that then returns to take the place of, negate, the necessity of his work. Both freedom and grace are, by definition, necessary: this is the lesson of predestination. And it is an introduction to Emerson's moral perfectionism, which you can almost see as a function of calling this theology into being. As the saying goes, if it didn't already exist, he would have had to create it.

Emerson here can be seen as diagnosing the impact of his own philosophy of self, the metaphysical reconfiguration of divinity applied to personhood, with all its democratic and heroic - political, all—implications. This is Emerson at his most self-conscious and at his most philosophical, and it is where we finally reach a post-theological point in our study of a theological motif - that is, with the ever-present and fully appreciated and politicized idea that "God is always with us." Our corporeal existence is our belief; we believe by being. "Fate" is, in the end, a rewriting of the covenant of works theology, a writing it out of theology into politics (or, one could say, into Žižek's political theory), a re-recognition of the autoconditionality of grace in an always already prior metaphysical covenant where we must do our work, where we must obey to be saved. However, the terms of this contract have changed, have become written within our very constitutions, as a covenant literally written on our hearts, a magical writing that says the same thing differently for each person, and is written by ourselves before we are born. This is not mysticism but theorization of theological motifs, a reading of concepts that exist, unconsciously, in our culture. The political implications of this reading can be seen only by tracing our actions back to their conceptual bases, or rather, as Žižek would say after Pascal, by understanding the materialism of our beliefs in our actions, our actions defining our beliefs. This 
is how ideology "works" in form, and the understanding of the form is the first step in acting differently. 


\section{CONCLUSION}

In the nature of the soul is the compensation for

the inequalities of condition.

Emerson, "Compensation" 301.

[T] he most horrible thing to encounter for a human being is this abyss of free will; when somebody simply acts out of free will ...

The truly traumatic thing is that miracles-not in the religious sense but in the sense of free acts-do happen, but it's very difficult to come to terms with them.

Žižek, Conversations with Žižek 166.

Perry Miller states that "to take Emerson literally is often hazardous" (594), which is itself a hazardous statement implying a traumatic potential if we should "take" Emerson not just "literally," as literature, but also as an arbiter and entrée to understanding ourselves both politically and theologically. I have tried to understand his and his predecessors' works in the context of the covenant, a historical theological structure that makes grace "work" through what Emerson calls "practical power." In a way, Emerson's attempts to describe his idea of "moral perfection," and Cavell's attempt to defend and claim this perfection for philosophy, may be analogous to my attempt to describe or reclaim the political "perfection" of perfect equality: a completely unrealistic goal that one is nevertheless called to work toward. 
The political implications of this calling are born through our contemporary difficulties in discussing American religiosity in theological terms, as a field of meaning divided against itself. To take one mainstream example, Robert Putnam and David Campbell, in American Grace: How Religion Divides and Unites Us (2010), identify and seek to explain a growing polarity in American religiosity, not between religions but rather between religiosity and its opposite. And yet, in spite of its title, there is no discussion of grace itself as either a theological construct or a more generalized descriptor of a mode of American belief (or lack thereof) ${ }^{172}$ Instead, they find theology is completely divorced from all aspects of "neighborliness" and other social and political indicators (except for one's political party membership), and they end their book by espousing "America's grace" as our ability to intermarry our way toward religious tolerance $(465-7,550)$. Though I situate my study at its beginning within the field of societal pain and the renewed discussion of American religiosity generated by the events of September 11, 2001, I do not seek to provide a way out of what is essentially a political dilemma. Instead, I have endeavored to describe one particular theological fault line, one internal to the political discourse, what I might call (borrowing from Badiou and Žižek) the materialism of grace as expressed through the covenant concept. By tracing this internal fissure or break within a theology fundamental to American political self-conception, we might better understand "American grace" as a descriptor of the division and inequality within ourselves.

The beginning of this study briefly surveyed our difficulties in discussing American religiosity outside false dichotomies of the religious and the secular that have carried over into our understanding of what is truly at stake politically in early American literature. It may be that

\footnotetext{
172 The two entries in the index for "grace" focus on the practice of "saying grace" over food and how this activity is an indicator of whether one will be a Republican or Democratic, the "grace gap."
} 
the best way for us now, after Emerson, to reach this understanding is through the American literature he helped create. At this time, I would only suggest two avenues through which such an understanding may appear, two alternative forms or routes of transcendence, both flying at inverse angles, in two very different postmodern fictional works: Thomas Pynchon's Against the Day (2006), and Tim LaHaye and Jerry Jenkins's Left Behind series of novels (1995-2007). Against the Day ends with its cherubim-like adventurers discovering that their airship, the Inconvenience, on which they have been flying through a late-nineteenth century geopolitical fantasia, has "transformed into its own destination," an ironically named non-self-identical ideal of a "good" that is never found but always promised on the horizon where any wish that can be made is at least addressed, if not always granted. For every wish to come true would mean that in the known Creation, good unsought and uncompensated would have evolved somehow, to become at least more accessible to us. No one aboard Inconvenience has yet observed any sign of this. $(1085)$

The novel ends five sentences later with the occupants of the Inconvenience perpetually flying "toward grace." Compare this to the equally fantastic (but, for many contemporary evangelical readers, doctrinally consistent) apocalyptic image of an airplane losing half of its passengers at the beginning of the first Left Behind novel, as the Elect are immediately transfigured to a wholly other destination. ${ }^{173}$ These are two very different trajectories for the theology of immediate, irresistible grace, along with the traumatic inconvenience of free will as a material yet miraculous event, and each scenario suggests very different terms for a covenantal relationship

173 Readers may intuit a connection with the motif and premise of the popular, semi-secular television series, Lost (2004-2010), which itself draws from the dramatic force of 9/11. 
with one's fellow passengers. The enduring popularity of the Left Behind series speaks to a strong religious millenarian instinct in the United States' self-awareness of its place in temporal and celestial history. The reliance of the novels on a sensationalized evangelical version of Emersonian self-determinism exemplifies the potentially frightening future of the American covenantal motif. ${ }^{174}$

We see Emerson himself a century ago indicating this potential when, in "New England Reformers," he expresses the "equality" that results from the spiritual dimensions of his own political theory, as both institutional and personal: "[M]an's equality to the church ... to the state ... to every other man." He then throws in a backhand compliment for the Reformed Protestant theology from whence this equality came: "It is yet in all men's memory, that the Calvinistic church denied to them the name of Christian. I think the complaint was confession: a religious church would not complain" (605-6). In a similar way, Emerson says earlier that one's "constitution will not mislead him" (604). He uses "constitution," here, as the term to define one's equality with what is greater than, while at the same time identical to, oneself-i.e., one's singular inequality and uniqueness is the exact marker of one's true comparable equivalents. A singularity can only equal another singularity, and each of these souls, demonstrating their unique genius, become one and the same, parts and particles of God. Žižek relates this state of being to the constitution of Christ—one could say Christ's inherent covenant—of being utterly

174 According to the official website, the 16-volume Left Behind series has sold more than 65 million copies since 1995. Seven of the novels - five following 9/11 — reached number one on The New York Times bestseller list. Publishers Weekly lists eight of the novels as among the ten overall bestselling novels in the United States for each year between 1999-2004. Desecration: Antichrist Takes the Throne, the ninth book in the series, was published on October 30, 2001, reached number one on the The New York Times bestseller list the following month, and was named Publishers Weekly bestselling novel for the year (Cloud; "New York Times Best Seller List"; "Publishers Weekly"). 
non-identical to His own divine status, which demonstrates a radical path for individuals toward becoming a truly, collectively exceptional people.

This math of individuality is a (final?) resolution of the conflict inherent in the covenant, bringing unity to the collective of solitary individuals through the very nature of their solitude. In other words, once one shares one's constitution with another, one loses oneself (and, one assumes, all of one's rights). We must collectively move forward together, separately, in order to be one with our individual selves. This is the ideological resolution of the Reformed Protestant covenant, and it can only work by converting the covenant into an impossible politics of collective inequality.

Cavell invokes a certain religious calling for American philosophy to prioritize whim (departure) over obligation (responsibility), in order to learn the vital present answer of "what [thought] wants to live in you":

As if sinking roots is not a matter of finding out where you want to live but finding out what wants to live in you. As if your roots - that is, your origins - are matters not of the past but precisely of the present, always, fatally. (30)

This mode or mood of thought, what we might call visionary determinism, is what I have applied to Emerson, and to Edwards and the Puritans, and to Žižek. The vital scholarly duty to find out what lives in us (whether we want it to or not) demands rooting around in the past, if only to understand — one hopes not fatally_one's present political opportunities. 


\section{WORKS CITED}

Adams, Todd L. "Tappan vs. Edwards on the Freedom Necessary for Moral Responsibility." Transactions of the Charles S. Peirce Society 40.2 (Spring 2004): 319-333. Print.

Ahlstrom, Sydney E. A Religious History of the American People. New Haven: Yale UP, 1972.

Allen, Alexander V. G. "The Freedom of the Will." Critical Essays on Jonathan Edwards. Ed. William J. Scheick \& Wayne Lesser. Boston: Hall, 1980. Print.

Allin, John. A Defence of the Answer Made Unto the Nine Questions. London, 1648. Print.

Altizer, Thomas J. J. The Gospel of Christian Atheism. Philadelphia: Westminster, 1966. Print. Asad, Talal. Formations of the Secular: Christianity, Islam, Modernity. Stanford, Calif: Stanford UP, 2003. Print.

Badiou, Alain. Saint Paul: The Foundation of Universalism. Stanford UP, 2003. Print.

Baker, J. Wayne. Heinrich Bullinger and the Covenant: The Other Reformed Tradition. Athens, Ohio: Ohio UP, 1980. Print.

---. "Heinrich Bullinger, the Covenant, and the Reformed Tradition in Retrospect." Sixteenth Century Journal 29.2 (1998): 359-376. Web.

Ball, John. A Treatise of the Covenant of Grace. Ed. Simeon Ashe. London, 1645. Web.

Baltzer, Klaus. The Covenant Formulary in Old Testament, Jewish, and Early Christian Writings. Philadelphia: Fortress Press, 1971. Print.

Barnstone, Aliki, Michael Tomasek Manson, and Carol J Singley, eds. The Calvinist Roots of the Modern Era. Hanover, NH: UP of New England, 1997. Print. 
Bellah, Robert N.. The Broken Covenant: American Civil Religion in Time of Trial. Chicago: U of Chicago P, 1992.

Bellah, Robert N., et al. The Good Society. New York: Vintage, 1992.

---. Habits of the Heart: Individualism and Commitment in American Life. Berkeley: U of California P, 1996.

Bercovitch, Sacvan. The American Jeremiad. Madison: U of Wisconsin P, 1978.

---. "Emerson, Individualism, and the Ambiguities of Dissent." South Atlantic Quarterly 89.3 (1990): 623-662. Print.

---. The Puritan Origins of the American Self. New Haven: Yale UP, 1975.

---. The Rites of Assent: Transformations in the Symbolic Construction of America. New York: Routledge, 1992.

---. Typology and Early American Literature. Amherst: U of Massachusetts P, 1972. Print.

Berk, Stephen E. Calvinism Versus Democracy; Timothy Dwight and the Origins of American Evangelical Orthodoxy. Hamden, Conn.: Archon Books, 1974. Print.

Bierma, Lyle D. "Federal Theology in the 16th Century: Two Traditions?." Westminster Theological Journal 45.2 (1983): 304-321. Print.

---. German Calvinism in the Confessional Age: The Covenant Theology of Caspar Olevianus. Grand Rapids, Mich.: Baker Books, 1996. Print.

---. "The Role of Covenant Theology in Early Reformed Orthodoxy." Sixteenth Century Journal 21.3 (1990): 453-462. Web. 25 Sept. 2010.

Bloom, Harold. "Emerson: The Glory and the Sorrows of American Romanticism." Virginia Quarterly Review 47 (1971): 546-563. Print. 
---. "Mr. America." New York Review of Books (1984): n. pag. Web. 18 Feb. 2012.

---. The American Religion: the Emergence of the Post-Christian Nation. New York: Simon \& Schuster, 1992. Print.

Bogue, Carl W. Jonathan Edwards and the Covenant of Grace. Cherry Hill, N.J.: Mack Publishing, 1975. Print.

Bonomi, Patricia U. Under the Cope of Heaven: Religion, Society, and Politics in Colonial America. New York: Oxford UP, 2003.

Boynton, Robert S. "Enjoy Your Žižek." Lingua Franca: The Review of Academic Life 8 (1998): 41-50. Print.

Bozeman, Theodore Dwight. To Live Ancient Lives: The Primitivist Dimension in Puritanism. Chapel Hill: U of North Carolina P, 1988. Print.

Bradley, Arthur. "Derrida's God: A Genealogy of the Theological Turn." Paragraph 29.3 (2006): 21-42. Web.

---. Negative Theology and Modern French Philosophy. New York: Routledge, 2004. Print.

Breger, Claudia. "The Leader's Two Bodies: Slavoj Žižek's Postmodern Political Theology." Diacritics 31.1 (2001): 73-90. Web.

Breitenbach, William. "The Consistent Calvinism of the New Divinity Movement." William and Mary Quarterly 41.2 (1984): 241-264. Web. 10 Nov. 2011.

Brooks, David. "What Life Asks of Us." New York Times 26 Jan 2009.

Brumm, Ursula. "Jonathan Edwards and Typology." Early American Literature: A Collection of Critical Essays. Ed. Michael T. Gilmore. Englewood Cliffs, NJ: Prentice-Hall, 1980. 70. Print. 
Budick, Emily Miller. "American Literature's Declaration of In/Dependence: Stanley Cavell, Nathaniel Hawthorne, and the Covenant of Consent." Summoning: Ideas of the Covenant and Interpretive Theory. Albany: State U of New York P, xvi, 1993. 211-227. Print.

Buell, Lawrence. "Emerson's Fate." Emersonian Circles: Essays in Honor of Joel Myerson. Ed. Wesley T. Mott \& Robert E. Burkholder. Rochester, NY: U of Rochester P, 1997. 11-28. Print.

---. "The Literary Significance of the Unitarian Movement." ESQ 33.4 (1987): 212-223. Print. Bulkeley, Peter. The Gospel-Covenant, or, The Covenant of Grace Opened. London, 1651. Web. Burke, Kenneth. On Symbols and Society. U of Chicago P, 1989.

Butler, Jon. Awash in a Sea of Faith: Christianizing the American People. Cambridge, Mass.: Harvard UP, 1990.

Butler, Judith, Ernesto Laclau, and Slavoj Žižek. Contingency, Hegemony, Universality: Contemporary Dialogues on the Left. London: Verso, 2000. Print.

Butler, Rex. Slavoj Žižek: Live Theory. Continuum International Publishing Group, 2005. Print. Caldwell, Patricia. The Puritan Conversion Narrative: The Beginnings of American Expression. Cambridge: Cambridge UP, 1983. Print.

Cannon, Vincent. "Spectres of Christ: Love, Christianity, and the Political in Slavoj Žižek's The Fragile Absolute." Qui Parle: Literature 12.2001 (2001): 201-18. Print.

Capper, Charles. “'A Little Beyond': The Problem of the Transcendentalist Movement in American History." Journal of American History 85.2 (1998): 502-539. Web. 17 Mar. 2012. 
Caputo, John D. The Prayers and Tears of Jacques Derrida: Religion without Religion. Bloomington: Indiana UP, 1997. Print.

Carroll, Anthony J. Protestant Modernity: Weber, Secularization, and Protestantism. Scranton, Pa.: U of Scranton P, 2007. Print.

Carse, James P. Jonathan Edwards \& the Visibility of God. New York: Scribner, 1967. Print.

Castillo, David R. "Ruminating America: The Surplus of the Dialectics of Discovery and the Example of Early Colonial Writing in Brazil." Torre de Papel 4.1994 (1994): 6-29. Print.

Cavell, Stanley. Emerson's Transcendental Etudes. Ed. David Justin Hodge. Stanford, CA: Stanford UP, 2003. xii, 2003. Print.

---. Themes Out of School: Effects and Causes. San Francisco: North Point Press, 1984. Print. Chai, Leon. Jonathan Edwards and the Limits of Enlightenment Philosophy. New York: Oxford UP, 1998. Print.

Cherry, Conrad. The theology of Jonathan Edwards: a reappraisal. Garden City, NY: Anchor Books, 1966. Print.

Chomsky, Noam, and Carlos Peregrín Otero. Radical Priorities. 2003.

Christiansen, Ellen Juhl. The Covenant in Judaism and Paul: A Study of Ritual Boundaries as Identity Markers. Leiden: E.J. Brill, 1995. Print.

Cloud, John. "Meet the Prophet: How an Evangelist and Conservative Activist Turned Prophecy into a Fiction Juggernaut." TIME.com. 23 June 2002. Web. 16 Apr. 2009.

Cohen, Charles. "The Post-Puritan Paradigm of Early American Religious History." William and Mary Quarterly 54.4 (1997): 695-722.

Cole, Phyllis. "From the Edwardses to the Emersons." CEA Critic 49.2-4 (1986): 70-78. Print. 
Conforti, Joseph. "Edwardsians, Unitarians, and the Memory of the Great Awakening, 18001840." American Unitarianism, 1805-1865. Ed. Conrad Edick Wright. Boston: Northeastern UP, 1989. 31-50. Print.

Coolidge, John S. The Pauline Renaissance in England: Puritanism and the Bible. Oxford: Clarendon, 1970. Print.

Corbett, Michael, and Julia Corbett Hemeyer. Politics and Religion in the United States. New York: Garland Pub., 1999.

Cotton, John. The Covenant of Gods Free Grace, Most Sweetly Unfolded, and Comfortably Applied to a Disquieted Soul.... London, 1645. Print.

---. The Covenant of Grace Discovering the Great Work of a Sinners Reconciliation to God. London, 1655. Web.

Coulter, Ann. Godless: The Church of Liberalism. Three Rivers Press, 2007.

"covenant, n.." Oxford English Dictionary. Second Edition. Oxford UP, 1989.

Coward, Harold G., Toby Foshay, and Jacques Derrida. Derrida and Negative Theology. Albany, N.Y.: State U of New York P, 1992. Print.

Crocco, Stephen D. "Paul Ramsey and the Works of Jonathan Edwards." Annual of the Society of Christian Ethics (1992): 157-172. Print.

Dahl, Robert Alan. On Political Equality. New Haven: Yale UP, 2006.

Daly, Glyn. "Politics and the Impossible: Beyond Psychoanalysis and Deconstruction." Theory Culture Society 16.4 (1999): 75-98. Web. 1 Feb. 2010.

Daniel, Stephen H. The Philosophy of Jonathan Edwards: A Study in Divine Semiotics. Bloomington: Indiana UP, 1994. Print. 
Dauber, Kenneth. "On Not Being Able to Read Emerson, or 'Representative Man'." boundary 2 21.2 (1994): 220-242. Web. 24 Feb. 2012.

Davenport, John. "An Answer of the Elders of the Serverall Churches in New-England." ChurchGovernment and Church-Covenant Discussed. Ed. Richard Mather. London, 1643. Print.

Davidson, Edward H. Jonathan Edwards, the Narrative of a Puritan Mind. Boston: Houghton, Mifflin, 1966. Print.

Davis, Creston, John Milbank, and Slavoj Žižek, eds. Theology and the Political: The New Debate. Durham: Duke UP, 2005. Print.

Dawkins, Richard. The God Delusion. Boston: Houghton Mifflin, 2006.

Delattre, Roland A. Beauty and Sensibility in the Thought of Jonathan Edwards; an Essay in Aesthetics and Theological Ethics. New Haven: Yale UP, 1968. Print.

---. "Recent Scholarship on Jonathan Edwards." Religious Studies Review 24.4 (1998): 369-375. Web. 5 Sept. 2011.

Delbanco, Andrew. The Puritan Ordeal. Cambridge: Harvard UP, 1989. Print.

Dennett, Daniel Clement. Breaking the Spell: Religion as a Natural Phenomenon. New York: Viking, 2006.

Derrida, Jacques. Acts of Religion. New York: Routledge, 2002. Print.

---. Adieu to Emmanuel Levinas. Stanford, Calif.: Stanford UP, 1999. Print.

---. Of Hospitality: Anne Dufourmantelle Invites Jacques Derrida to Respond. Trans. Rachel Bowlby. Stanford, Calif.: Stanford UP, 2000. Print.

---. Politics of Friendship. London: New York: Verso, 1997. Print.

---. Positions. 2nd ed. Trans. Alan Bass. London: Continuum, 2002. Print. 
Derrida, Jacques, and Gianni Vattimo. Religion. Stanford, CA: Stanford UP, 1998. Print.

Dewey, John. "Emerson-The Philosopher of Democracy." International Journal of Ethics 13.4 (1903): 405-413. Print.

Doherty, Joseph F. "Emerson and the Loneliness of the Gods." Texas Studies in Literature and Language 16 (1974): 65-75. Print.

D'Souza, Dinesh. What's So Great About Christianity. Regnery Publishing, 2007.

Duffy, Edward. "Stanley Cavell's Redemptive Reading: A Philosophical Labour in Progress." University of Toronto Quarterly 65.4 (1996): 561-583. Print.

Dunn, Charles W. American Political Theology: Historical Perspective and Theoretical Analysis. New York: Praeger, 1984.

Durant, Robert. "A "New Covenant" Kept: Core Values, Presidential Communications, and the Paradox of the Clinton Presidency." Presidential Studies Quarterly 36.3 (2006): 345-372.

Eagleton, Terry. "Enjoy!." Paragraph 24.2 (2001): 40. Web. 3 Jan. 2010.

Edwards, Jonathan. Freedom of the Will. Ed. Paul Ramsey. New Haven: Yale UP, 1957. Print. The Works of Jonathan Edwards v. 1.

---. Writings on the Trinity, Grace, and Faith. New Haven: Yale UP, 2003. Print. The Works of Jonathan Edwards v. 21.

Eisenach, Eldon J. The Next Religious Establishment: National Identity And Political Theology In Post-Protestant America. Lanham, Md.: Rowman \& Littlefield Publishers, 2000.

Elazar, Daniel Judah. Covenant \& Commonwealth: From Christian Separation through the Protestant Reformation. New Brunswick, N.J.: Transaction, 1996. 
---. Covenant \& Constitutionalism: The Great Frontier and the Matrix of Federal Democracy. New Brunswick, N.J.: Transaction Publishers, 1998.

---. Covenant \& Polity in Biblical Israel: Biblical Foundations \& Jewish Expressions. New Brunswick, N.J.: Transaction Publishers, 1995.

Elliott, Emory. Power and the Pulpit in Puritan New England. Princeton, N.J.: Princeton UP, 1975. Print.

Emerson, Amanda. "From Equivalence to Equity: The Management of an American Myth." Differences: A Journal of Feminist Cultural Studies 14.2 (2003): 78-105. Web.

Emerson, Ralph Waldo. Essays \& Poems. Library of America, 1996. Print.

---. Journals and Miscellaneous Notebooks. Vol. VII. Cambridge: Harvard UP, 1960. Print.

Equality for Women: Where Do We Stand on Millennium Development Goal 3? Washington, DC: World Bank, 2008.

Fite, David. Harold Bloom: The Rhetoric of Romantic Vision. Amherst: U of Massachusetts P, 1985. Print.

Foster, Stephen. The Long Argument: English Puritanism and the Shaping of New England Culture, 1570-1700. Chapel Hill: U of North Carolina P, 1991. Print.

Frank, Barney, "U.S. House Committee on Financial Services Hearing," United States Congressional Record. July 16, 2008.

Fukuyama, Francis "The Calvinist Manifesto." New York Times 13 Mar 2005: 35.

Fuller, Randall. Emerson's Ghosts: Literature, Politics, and the Making of Americanists. New York: Oxford UP, 2007. Print.

Galchen, Rivka. "Dream Machine." New Yorker 87.11 (2011): 34-43. Print. 
Gandhi, Mohandas K. "Religion Quotes." About.com Quotations. Web. 17 Mar. 2012.

Gelernter, David. Americanism:The Fourth Great Western Religion. Doubleday, 2007.

Ghosh, P. "Max Weber's idea of 'Puritanism': a case study in the empirical construction of the Protestant ethic." History of European Ideas 29.2 (2003): 183 - 221.

Goddard, H. C. "Unitarianism \& Transcendentalism." American Transcendentalism; an Anthology of Criticism. Ed. Brian M. Barbour. Notre Dame, Ind.: U of Notre Dame P, 1973. 159-177. Print.

Gottlieb, Anthony. "Athiests with Attitude." The New Yorker 21 May 2007: 77-80.

Gould, Philip. Covenant and Republic: Historical Romance and the Politics of Puritanism. Cambridge: Cambridge UP, 1996. x, 1996. Print.

Grasso, Christopher. "Misrepresentations Corrected: Jonathan Edwards and the Regulation of Religious Discourse." Jonathan Edwards's writings: text, context, interpretation. Ed. Stephen J. Stein. Bloomington, Ind.: Indiana UP, 1996. 19-38. Print.

Gray, John. Black Mass: Apocalyptic Religion and the Death of Utopia. New York: Farrar Straus and Giroux, 2007.

Greaves, Richard L. "John Bunyan and Covenant Thought in the Seventeenth Century." Church History 36.2 (1967): 151-169. Web. 26 Sept. 2010.

---. "The Origins and Early Development of English Covenant Thought." The Historian 31.1 (1968): 21-35. Web. 25 Sept. 2010.

Grodzins, Dean. "Unitarianism.” The Oxford Handbook of Transcendentalism. Ed. Joel Myerson, Sandra Harbert Petrulionis, \& Laura Dassow Walls. Oxford UP, 2010. Print. 
Guelzo, Allen C. Edwards on the Will: A Century of Theological Debate. Vol. 1. Middletown, Conn.: Wesleyan UP, 1989. Print.

---. "Freedom of the Will." The Princeton Companion to Jonathan Edwards. Ed. Sang Hyun Lee. Princeton, N.J.: Princeton UP, 2005. 115-129. Print.

---. "From Calvinist Metaphysics to Republican Theory: Jonathan Edwards and James Dana on Freedom of the Will." Journal of the History of Ideas 56.3 (1995): 399-418. Web. 10 Nov. 2011.

Guerra, Gustavo. "Thinking Aslant: Žižek and Pragmatism." JPCS: Journal for the Psychoanalysis of Culture \& Society 6.2001 (2001): 21-28. Print.

Gura, Philip F. "Review: Jonathan Edwards in American Literature." Early American Literature 39.1 (2004): 147-166. Web. 10 May 2009.

Hagen, Kenneth. "From Testament to Covenant in the Early Sixteenth Century." Sixteenth Century Journal 3.1 (1972): 1-24. Web. 25 Sept. 2010.

Hall, David D. "Narrating Puritanism." New Directions in American Religious History. New York: Oxford UP, 1997. 51-83.

---. "On Common Ground: The Coherence of American Puritan Studies." William and Mary Quarterly 44.2 (1987): 193-229. Web. 27 Dec. 2010.

---. The Antinomian Controversy, 1636-1638: A Documentary History. Durham: Duke UP, 1990. Print.

Hall, Timothy D. "Assurance, Community, and the Puritan Self in the Antinomian Controversy, 1636- 38." Puritanism and Its Discontents. Ed. Laura Lunger Knoppers. Newark, NJ: Associated UP, 2003. Print. 
Hall, W. Dewey. "From Edwards to Emerson: A Study of the Teleology of Nature." Early Protestantism and American Culture. Ed. Michael Schuldiner. Lewiston, NY: Mellen, 1995. 123-147. Print. Studies in Puritan American Spirituality, 5.

Harlan, David. The Clergy and the Great Awakening in New England. Ann Arbor, Mich.: UMI Research Press, 1980. Print.

Harris, Sam. Letter to a Christian Nation. New York, NY: Alfred A. Knopf, 2006.

---. The End of Faith: Religion, Terror, and the Future of Reason. New York: W.W. Norton \& Co., 2004.

Hart, Kevin. The Trespass of the Sign: Deconstruction, Theology and Philosophy. New York: Fordham UP, 2000. Print.

Hart, William David. "Slavoj Žižek and the Imperial/Colonial Mode of Religion." Nepantla: Views from the South 3.3 (2002): 553-78. Print.

Hatch, Nathan O., and Harry S. Stout. Jonathan Edwards and the American Experience. New York: Oxford UP, 1988. Print.

Hayman, Robert L., and Leland Ware. Choosing Equality: Essays and Narratives on the Desegregation Experience. University Park, Pa.: Pennsylvania State UP, 2009. Hedges, Chris. I Don't Believe in Atheists. Free Press, 2008.

---. Losing Moses on the Freeway: The 10 Commandments in America. Free Press, 2006.

Heimert, Alan. Religion and the American mind, from the Great Awakening to the Revolution. Cambridge: Harvard UP, 1966. Print.

Helm, Paul. "Introduction." Treatise on Grace. Greenwood, S.C.: Attic Press, 1971. 1-23. Print. 
Hill, Christopher. "Covenant Theology and the Concept of 'A Public Person'." Powers, Possessions and Freedom: Essays in Honour of C.B. Macpherson. Ed. Alkis Kontos \& Victor Svacek. Toronto: U of Toronto P, 1979. 3-22. Print.

Hillers, Delbert R. Covenant: The History of a Biblical Idea. Baltimore,: Johns Hopkins Press, 1969.

Hitchens, Christopher. God is Not Great: How Religion Poisons Everything. New York: Twelve, 2007.

Hodder, Alan D. "'After a High Negative Way’: Emerson's 'Self-Reliance' and the Rhetoric of Conversion." Harvard Theological Review 84.4 (1991): 423-446. Print.

Hoekema, Anthony A. "Covenant of Grace in Calvin's Teaching." Calvin Theological Journal 2.2 (1967): 133-161. Print.

Hoffert, Robert W. "The Declaration of Independence and the Articles of Confederation: A Completed Constitutional Covenant." The Declaration of Independence: Origins and Impact. Washington, D.C.: CQ Press, 2002. 347.

Holbrook, Clyde A. The Ethics of Jonathan Edwards: Morality and Aesthetics. Ann Arbor: U of Michigan P, 1973. Print.

Holbrook, Thomas Arthur. "The Elaborated Labyrinth: The American Habit of Typology." 1985. Web.

Holifield, E. Brooks. "Edwards as Theologian." The Cambridge Companion to Jonathan Edwards. Ed. Stephen J. Stein. Cambridge : Cambridge UP, 2007. 144-161. Print. ---. The Covenant Sealed: The Development of Puritan Sacramental Theology in Old and New England, 1570-1720. New Haven: Yale UP, 1974. Print. 
Hooker, Thomas. The Paterne of Perfection. London, 1640. Web.

Howe, Daniel Walker. "‘At Morning Blest and Golden-Browed’: Unitarians, Transcendentalists, and Reformers, 1835-1865." A Stream of Light: A Sesquicentennial History of American Unitarianism. Ed. Conrad Wright. Boston: Unitarian Universalist Association, 1975. $33-$ 61. Print.

---. The Unitarian Conscience: Harvard Moral Philosophy, 1805-1861. Cambridge, Mass.: Harvard UP, 1970. Print.

Hughey, Michael W. "The Political Covenant: Protestant Foundations of the American State." State, Culture and Society 1.1 (1984): 113.

Hungerford, Amy. Postmodern Belief: American Literature and Religion Since 1960. Princeton: Princeton UP, 2010. Print.

Husband, Paul. "Church membership in Northampton: Solomon Stoddard versus Jonathan Edwards." 1990.

Hutchison, William R. The Transcendentalist Ministers: Church Reform in the New England Renaissance. New Haven, CT: Yale UP, 1959. Print.

Irey, Eugene. "A Concordance to the Essays of Ralph Waldo Emerson.” Web. 1 Jan. 2012. James, William. "The Dilemma of Determinism." Essays in Pragmatism. New York, 1955. 37 64. Print.

Jameson, Fredrick. "The Vanishing Mediator; or, Max Weber as Storyteller." The Ideologies of Theory. 1988. 3-34. Print.

Jeanes, W. P. "Jonathan Edwards's Conception of Freedom of the Will." Scottish Journal of Theology 14 (1961): 1-14. Print. 
De Jong, Peter Y. The Covenant Idea in New England Theology, 1620-1847. Grand Rapids, MI: Eerdmans, 1945. Print.

Joswick, Thomas P. "The Conversion Drama of 'Self-Reliance': A Logological Study." American Literature: A Journal of Literary History, Criticism, and Bibliography 55.4 (1983): 507524. Print.

Karlberg, M. W. "Covenant Theology in Reformed Perspective" (2000): n. pag. Print.

Kidd, Thomas S. "From Puritan to Evangelical: Changing Culture in New England, 1689-1740." 2001: n. pag. Print.

Kirsch, Adam. "The Deadly Jester." New Republic 239.10 (2008): 30-37. Web. 30 Dec. 2009.

Kline, Meredith G. By Oath Consigned: A Reinterpretation of the Covenant Signs of Circumcision and Baptism. Michigan: Eerdmans, 1968. Print.

Knebel, Sven. "The Modern Schoolman: Jonathan Edwards's Moral Necessity, or How to Defend Calvinism in Eighteenth-Century New England." The Modern Schoolman 73 (1996): 129-139. Print.

Knutson, Andrea. "American Spaces of Conversion: The Conductive Imaginaries of Jonathan Edwards, Ralph Waldo Emerson, and William James." 2006.

Kotsko, Adam. Žižek and Theology. London: T \& T Clark, 2008. Print.

Kramnick, Isaac, and R. Laurence Moore. The Godless Constitution: The Case Against Religious Correctness. New York: Norton, 1996.

LaHaye, Tim F., and Jerry B. Jenkins. Left Behind: A Novel of the Earth's Last Days. Wheaton, Ill.: Tyndale House, 1995. Print.

Lang, J. Stephen. "Jonathan Edwards." Church History 4 (1985): 1. Print. 
Lange, Lou Ann. The Riddle of Liberty: Emerson on Alienation, Freedom, and Obedience. Atlanta, Ga.: Scholars Press, 1986. Print.

Lee, Sang Hyun. "Grace and Justification by Faith Alone." The Princeton Companion to Jonathan Edwards. Ed. Sang Hyun Lee. Princeton, N.J.: Princeton UP, 2005. 130-146. Print.

---. The Philosophical Theology of Jonathan Edwards. Princeton, NJ: Princeton UP, 1988. Print.

Lesser, M. X. Jonathan Edwards: An Annotated Bibliography, 1979-1993. Vol. 30. Westport, Conn.: Greenwood Press, 1994. Print.

---. Jonathan Edwards: a Reference Guide. Boston, MA: G.K. Hall, 1981. Print.

---. Reading Jonathan Edwards: An Annotated Bibliography in Three Parts, 1729-2005. Wm. B. Eerdmans Publishing Company, 2008. Print.

Lettinga, Neil. "Covenant Theology Turned Upside Down: Henry Hammond and Caroline Anglican Moralism: 1643-1660." Sixteenth Century Journal 24.3 (1993): 653-669. Web.

Lilla, Mark. The Stillborn God: Religion, Politics, and the Modern West. New York: Knopf, 2007.

Lincoln, Charles F. "The Biblical Covenants." Bibliotheca Sacra 100.398 (1943): 309-323. Print.

---. "The Development of the Covenant Theory." Bibliotheca Sacra 100.397 (1943): 134-163. Print.

Lips, Roger Cameron. "The Spirit's Holy Errand: A Study of Continuities of Thought from Jonathan Edwards to Ralph Waldo Emerson." 1976: n. pag. Print. 
Lopez, Michael. "The Conduct of Life: Emerson's Anatomy of Power." The Cambridge Companion to Ralph Waldo Emerson. Ed. Joel Porte \& Saundra Morris. Cambridge: Cambridge UP, 1999. 243-266. Print.

Lowance, Mason. "From Edwards to Emerson to Thoreau: A Revaluation." American Transcendental Quarterly: A Journal of New England Writers 18 (1973): 3-12. Print.

Makarushka, Irena S. M. Religious Imagination and Language in Emerson and Nietzsche. New York: Macmillan Press, 1994. Print. Studies in Literature and Religion.

Marsden, George M. "Perry Miller's Rehabilitation of the Puritans: A Critique." Church History 39.1 (1970): 91-105. Web. 25 Sept. 2010.

Martin, David. On Secularization: Towards a Revised General Theory. Aldershot, England: Ashgate, 2005. Print.

Mather, Richard. An Apologie of the Churches in New-England for Church-Covenant. London, 1643. Web.

Matthiessen, F. O. American Renaissance; Art and Expression in the Age of Emerson and Whitman. London: Oxford UP, 1941. Print.

Mavrodes, George. "Is the Past Unpreventable?" Faith and Philosophy 1 (1984): 131-146. Print. May, Henry F. "The Recovery of American Religious History." The American Historical Review 70.1 (1964): 79-92. Web.

McCarl, Mary Rhinelander. "Thomas Shepard's Record of Relations of Religious Experience, 1648- 1649." William and Mary Quarterly 48.3 (1991): 432-466. Web. 26 Sept. 2010. McClymond, Michael J. "The Protean Puritan: The Works of Jonathan Edwards, Volumes 8 to 16." Religious Studies Review 24.4 (1998): 335-383. Web. 5 Sept. 2011. 
McCoy, Charles S., and J. Wayne Baker. Fountainhead of Federalism: Heinrich Bullinger and the Covenantal Tradition. Louisville, Ky.: Westminster/John Knox Press, 1991. Print.

McDermott, Gerald R. One Holy and Happy Society: The Public Theology of Jonathan Edwards. University Park, Pa.: Pennsylvania State UP, 1992. Print.

---. "Poverty, Patriotism, and National Covenant: Jonathan Edwards and Public Life." The Journal of Religious Ethics 31.2 (2003): 229-251. Print.

McGiffert, Michael. "Covenant, Crown, and Commons in Elizabethan Puritanism." The Journal of British Studies 20.1 (1980): 32-52. Web. 20 Dec. 2010.

---. "Grace and Works: The Rise and Division of Covenant Divinity in Elizabethan Puritanism." The Harvard Theological Review 75.4 (1982): 463-502. Web. 25 Sept. 2010.

---. "The Problem of the Covenant in Puritan Thought: Peter Bulkeley’s Gospel-Covenant." The New England Historical and Genealogical Register 130 (1976): 107-29. Print.

McKim, Donald K. "William Perkins and the Theology of the Covenant." Studies of the Church in History. Ed. Horton Davies. Allison Park, PA: Pickwick, 1983. 85-101. Print.

McLaren, Peter. "Slavoj Žižek's Naked Politics: Opting for the Impossible, a Secondary Elaboration." JAC: A Journal of Composition Theory 21.2001 (2001): 613-47. Print.

McMillin, T. S. Our Preposterous Use of Literature: Emerson and the Nature of Reading. Urbana: U of Illinois P, 2000. Print.

Melville, Stephen. "Oblique and Ordinary: Stanley Cavell's Engagement of Emerson." American Literary History 5.1 (1993): 172-192. Print.

Merin, Yuval. Equality for Same-Sex Couples: The Legal Recognition of Gay Partnerships in Europe and the United States. U of Chicago P, 2002. 
Metzger, Charles R. "Emerson's Religious Conception of Beauty." Journal of Aesthetics and Art Criticism 11 (1952): 67-74. Print.

Michener, James A. The Covenant. Fawcett Crest, 1987. Print.

Michener, Ronald T. Engaging Deconstructive Theology. Aldershot, England: Burlington, VT: Ashgate, 2007. Print.

Milder, Robert. "Emerson’s Two Conversions." ESQ 33.1 (1987): 20-34. Print.

Miller, Perry. Errand into the Wilderness. Harper \& Row, 1964. Print.

---. "Introduction." The Transcendentalists, an Anthology. Cambridge, MA: Harvard UP, 1950. 3-15. Print.

---. Jonathan Edwards. Vol. 75. New York: Meridian Books, 1949. Print.

---. "Jonathan Edwards to Emerson." New England Quarterly: A Historical Review of New England Life and Letters 13.4 (1940): 589-617. Print.

---. "The Half-Way Covenant." New England Quarterly: A Historical Review of New England Life and Letters 6.4 (1933): 676-715. Web.

---. The New England Mind: From Colony to Province. Cambridge,: Harvard UP, 1953. Print.

---. The New England Mind: The Seventeenth Century. New York: Macmillan, 1939. Print.

"Miscellanies Index | The Jonathan Edwards Center at Yale University." Web. 12 Nov. 2011.

Mitchell, Louis J. "The theological aesthetics of Jonathan Edwards." Theology Today 64.1 (2007): 36-46. Print.

Møller, Jens G. "The Beginnings of Puritan Covenant Theology." Journal of Ecclesiastical History 14 (1963): 46-67. Print. 
Morgan, Edmund Sears. Visible Saints: The History of a Puritan Idea. New York: New York UP, 1963. Print.

Moriarty, Michael. "Žižek, Religion and Ideology." Paragraph 24.2 (2001): 125. Web. 3 Jan. 2010.

Moseley, James G. A Cultural History of Religion in America. Westport, Conn: Greenwood Press, 1981.

Mott, Wesley T. "Emerson and Antinomianism: The Legacy of the Sermons." American Literature 50.3 (1978): 369-397. Print.

Murphy, Arthur E. "Jonathan Edwards on Free Will and Moral Agency." Philosophical Review 68.2 (1959): 181-202. Web. 9 Sept. 2011.

Murrin, John M. "No Awakening, No Revolution? More Counterfactual Speculations." Reviews in American History 2 (1983): 161. Print.

Myers, Tony. Slavoj Žižek. Routledge, 2003. Print.

Nancy, Jean-Luc. Dis-Enclosure: The Deconstruction of Christianity. New York: Fordham UP, 200. Print.

Nealon, Jeffrey T. "The Cash Value of Paradox: Žižek's Rhetoric." JAC 21.2001 (2001): 599-605. Print.

New, Elisa. "Beyond the Romance Theory of American Vision: Beauty and the Qualified Will in Edwards, Jefferson, and Audubon." American Literary History 7.3 (1995): 381 -414. Web. 10 Nov. 2011.

"New York Times Best Seller List." 16 Apr 2009. Web. 
Nicholson, Ernest W. God and His People: Covenant and Theology in the Old Testament. Oxford: Oxford UP, 1986.

Nolfi, George. The Adjustment Bureau. Universal Pictures, 2011. Film.

Noll, Mark A. "Jonathan Edward's Freedom of the Will Abroad." Jonathan Edwards at 300: Essays on the Tercentenary of His Birth. Ed. Harry S. Stout, Kenneth P. Minkema, \& Caleb J. D. Maskell. Lanham, Md.: UP of America, 2005. 98-110. Print.

---. The Old Religion in a New World: The History of North American Christianity. Grand Rapids, Mich.: Eerdmans, 2002.

Osgood, Robert L. The History of Special Education: A Struggle for Equality in American Public Schools. Westport, Conn: Praeger, 2008.

Packer, Barbara. Emerson's Fall: A New Interpretation of the Major Essays. New York: Continuum, 1982. Print.

---. "Turning to Emerson." Common Knowledge 5.2 (1996): 51-60. Print.

Padover, Saul K. "Ralph Waldo Emerson: The Moral Voice in Politics." Political Science Quarterly 74 (1959): 334-350. Print.

Paul, Sherman. Emerson's Angle of Vision: Man and Nature in American Experience. Cambridge, Ma.: Harvard UP, 1952. Print.

Pecora, Vincent P. Secularization and Cultural Criticism: Religion, Nation, \& Modernity. Chicago: U of Chicago P, 2006. x, 2006. Print.

Perkins, William. The vvorkes of that famous and vvorthy minister of Christ in the Vniuersitie of Cambridge, Mr. William Perkins. London, 1626. Web. 
Pettit, Norman. The Heart Prepared: Grace and Conversion in Puritan Spiritual Life. 2nd ed. Middletown, Conn: Wesleyan UP, 1989. Print.

Pope, Robert G. The Half-Way Covenant: Church Membership in Puritan New England. Princeton, NJ: Princeton UP, 1969. Print.

Porte, Joel, and Saundra Morris, eds. The Cambridge Companion to Ralph Waldo Emerson. Cambridge, U.K. ; New York: Cambridge UP, 1999. Print.

Pound, Marcus. Žižek: A (Very) Critical Introduction. Eerdmans, 2008. Print.

"Publishers Weekly List of Bestselling Novels in the United States in the 1990s." Wikipedia. 16 Apr 2009. Web.

Putnam, Robert D, and David E Campbell. American Grace: How Religion Divides and Unites Us. New York, NY: Simon \& Schuster, 2010. Print.

Pynchon, Thomas. Against the Day. New York: Penguin Press, 2006. Print.

Ramsey, Paul. "Introduction." Freedom of the Will. Edwards.

Raschke, Carl A. The Alchemy of the Word: Language and the End of Theology. Missoula, Mont.: Scholars Press, 1979. Print.

Redfield, Marc. "War on Terror." Provocations to Reading: J. Hillis Miller and the Democracy to Come. New York: Fordham UP, 2005. 128-158.

Reed, Peyton. Yes Man. Warner Bros. Pictures, 2008. Film.

Reid, W. Stanford. "John Knox's Theology of Political Government." Sixteenth Century Journal 19.4 (1988): 529-540. Web.

Riley, I. Woodbridge. "Jonathan Edwards." Critical Essays on Jonathan Edwards. Ed. William J. Scheick \& Wayne Lesser. Boston: Hall, 1980. Print. 
Robinson, David M. Apostle of Culture: Emerson as Preacher and Lecturer. Philadelphia: U of Pennsylvania P, 1982. Print.

---. "Grace and Works: Emerson's Essays in Theological Perspective." American Unitarianism, 1805-1865. Ed. Conrad Edick Wright. Boston: Northeastern UP, 1989. 121-142. Print.

---. "Transcendentalism and Its Times." The Cambridge Companion to Ralph Waldo Emerson. Ed. Joel Porte \& Saundra Morris. Cambridge: Cambridge UP, 1999. 13-29. Print. von Rohr, John. "Covenant and Assurance in Early English Puritanism." Church History 34.2 (1965): 195-203. Web. 20 Dec. 2010.

---. The Covenant of Grace in Puritan Thought. Atlanta, Ga.: Scholars Press, 1986. Print. Roth, Wolfgang, Rosemary R. Ruether, and Elizabeth L. McWhorter. The Liberating Bond: Covenants -- Biblical and Contemporary. New York: Friendship Press, 1978. Print. Sacks, Jonathan. "Obama renews a covenant and inspires fresh hope." The Times (London) 24 Jan 2009: 102.

Samuelsson, Kurt. Religion and Economic Action: A Critique of Max Weber. Trans. D. C Coleman. New York: Harper Torchbooks, 1961.

Santner, Eric L. "Freud, Žižek, and the Joys of Monotheism." American Imago 54.1997 (1997): 197-207. Print.

Schafer, Thomas. "Jonathan Edwards' Conception of the Church." Church History 24 (1955): 5166. Print.

Schaff, Philip. The Creeds of Christendom, with a History and Critical Notes. Grand Rapids, Mich.: Baker Book House, 1977. Print. 
Scharlemann, Robert P., ed. Theology at the End of the Century: A Dialogue on the Postmodern. Charlottesville: UP of Virginia, 1990. Print.

Scheick, William J. The Writings of Jonathan Edwards: Theme, Motif, and Style. College Station: Texas A \& M UP, 1975. Print.

Schmotter, James W. "The Irony of Clerical Professionalism: New England's Congregational Ministry and the Great Awakening." American Quarterly 31 (1979): 158-160. Print.

Shea, Daniel B. "Deconstruction Comes to Early 'America': The Case of Edwards." Early American Literature 21.3 (1986): 268-274. Print.

Seaver, Paul S. The Puritan Lectureships: The Politics of Religious Dissent, 1560-1662. Stanford: Stanford UP, 1970. Print.

Shachar, Ayelet. The Birthright Lottery: Citizenship and Global Inequality. Cambridge, Mass.: Harvard UP, 2009.

Sharpe, Matthew. Slavoj Žižek: A Little Piece of the Real. Ashgate Publishing, Ltd., 2004. Print. ---. "The Sociopolitical Limits of Fantasy: September 11 and Slavoj Žižek's Theory of Ideology." Cultural Logic 5.2002 (2002): 40. Print.

Shea, William M., and Peter A. Huff. Knowledge and Belief in America: Enlightenment Traditions and Modern Religious Thought. Washington, D.C.: Woodrow Wilson Center Press, 1995.

Shumway, David R. "The Star System in Literary Studies." PMLA 112.1997 (1997): 85-100. Print.

Shepard, Thomas. God's Plot: Puritan Spirituality in Thomas Shepard's Cambridge. Ed. Michael McGiffert. Amherst: U of Massachusetts P, 1994. Print. 
---. Thomas Shepard's "Confessions." Ed. George Selement \& and Bruce C. Woolley. Boston: Colonial Society of Massachusetts, 1981. Print.

Smiley, Tavis. The Covenant with Black America. Chicago: Third World Press, 2006.

Spolsky, Ellen, ed. Summoning: Ideas of the Covenant and Interpretive Theory. Albany: State U of New York P, 1993. xvi, 1993. Print.

Stoever, William K. B. A Faire and Easie Way to Heaven: Covenant Theology and Antinomianism in Early Massachusetts. Middletown, Conn.: Wesleyan UP, 1978. Print.

Stout, Harry S. "The Puritans and Edwards." Jonathan Edwards and the American Experience. Ed. Nathan O. Hatch \& Harry S. Stout. New York: Oxford UP, 1988. 142-159. Print.

Stout, Harry S., and D. G. Hart. New Directions in American Religious History. New York: Oxford UP, 1997.

Strehle, Stephen. Calvinism, Federalism, and Scholasticism: A Study of the Reformed Doctrine of Covenant. Bern: Peter Lang, 1988. Print.

Sussman, Henry. The Task of the Critic: Poetics, Philosophy, and Religion. New York, NY: Fordham UP, 2005. Print.

Tanenbaum, Leora. Taking Back God: American Women Rising up for Religious Equality. New York: Farrar, Straus and Giroux, 2009.

Taylor, Mark C. Erring: A Postmodern Atheology. Chicago: U of Chicago P, 1984. Print. Trinterud, Leonard J. "The Origins of Puritanism." Church History: Studies in Christianity and Culture 20.01 (1951): 37-57. Web. 25 Sept. 2010.

Vowell, Sarah. The Wordy Shipmates. New York: Riverhead Books, 2008. 
de Vries, Hent. Philosophy and the Turn to Religion. Baltimore, Md.: Johns Hopkins UP, 1999. Print.

---. Religion: Beyond a Concept. New York: Fordham UP, 2008. Print.

---. "The Two Sources of the 'Theological Machine': Jacques Derrida and Henri Bergson on Religion, Technicity, War, and Terror." Theology and the Political: The New Debate. Ed. Creston Davis, John Milbank, \& Slavoj Žižek. Durham: Duke UP, 2005. Print.

de Vries, Hent, and Lawrence Eugene Sullivan. Political Theologies: Public Religions in a PostSecular World. New York: Fordham UP, 2006.

Waggoner, Hyatt H. "'Grace' in the Thought of Emerson, Thoreau, and Hawthorne." ESQ 54 (1969): 68-72. Print.

Wald, Kenneth D. Religion and Politics in the United States. Lanham, Md.: Rowman \& Littlefield, 2003.

Walker, Williston. The Creeds and Platforms of Congregationalism. New York: Scribners, 1893. Print.

Wallace, Dewey D. Puritans and Predestination: Grace in English Protestant Theology, 15251695. Chapel Hill: U of North Carolina P, 1982. Print.

Wallis, Jim. God's Politics: Why the Right Gets It Wrong and the Left Doesn't Get It. HarperOne, 2005.

Ward, J. A. "Emerson and 'The Educated Will': Notes on the Process of Conversion." ELH 34.4 (1967): 495-517. Web. 20 Feb. 2012.

Weir, David A. Early New England: A Covenanted Society. Eerdmans, 2005. Print. 
---. The Origins of the Federal Theology in Sixteenth-Century Reformation Thought. Oxford: Clarendon Press, 1990. Print.

Whicher, Stephen E. Freedom and Fate: An Inner Life of Ralph Waldo Emerson. Philadelphia: U of Pennsylvania P, 1953. Print.

White, Peter. "The Rise of Arminianism Reconsidered." Past \& Present 101 (1983): n. pag. Print.

Whittemore, Robert C. The Transformation of the New England Theology. New York: P. Lang, 1987. Print.

Wider, Sarah Ann. The Critical Reception of Emerson: Unsettling All Things. Rochester, NY: Camden House, 2000. Print.

Winquist, Charles E. Epiphanies of Darkness: Deconstruction in Theology. Philadelphia: Fortress Press, 1986. Print.

Winthrop, John. "A Modell of Christian Charity." The Winthrop Papers: Volume 2, 1623-1630. Boston: The Massachusetts Historical Society, 1931. 282-95. Print.

Witte, John Jr. "Blest be the Ties That Bind: Covenant and Community in Puritan Thought." Emory Law Journal 36 (1987): 579. Web. 25 Sept. 2010.

Wolfe, Cary. "Alone with America: Cavell, Emerson, and the Politics of Individualism." New Literary History 25.1 (1994): 137-157. Print.

Wright, Conrad. "Introduction." A Stream of Light: A Sesquicentennial History of American Unitarianism. 1st ed. Ed. Conrad Wright. Boston: Unitarian Universalist Association, 1975. xi-xiv. Print.

---. The Liberal Christians: Essays on American Unitarian History. Boston: Beacon Press, 1970. Print. 
Zaret, David. The Heavenly Contract: Ideology and Organization in Pre-Revolutionary Puritanism. Chicago: U of Chicago P, 1985. Print.

Žižek, Slavoj. "A Plea for a Return to Différance (with a Minor Pro Domo Sua)." Critical Inquiry 32.2006 (2006): 226-49. Print.

---. "Carl Schmitt in the Age of Post-Politics." The Challenge of Carl Schmitt. Ed. Chantal Mouffe. London: Verso, 1999. 18-37. Print.

---. Did Somebody Say Totalitarianism?: Five Interventions In The (Mis)Use Of A Notion. London: Verso, 2001. Print.

---. "Disputations: Who Are You Calling Anti-Semitic?." The New Republic (2009): n. pag. Web. 19 Dec. 2009.

---. "Fantasy as a Political Category: A Lacanian Approach." JPCS 1.1996 (1996): 77-85. Print.

---. "Foreword to the Second Edition: Enjoyment within the Limits of Reason Alone." For They Know Not What They Do: Enjoyment as a Political Factor. 2nd ed. London: Verso, 2002. xi-cvii. Print.

---. For They Know Not What They Do: Enjoyment as a Political Factor. London: Verso, 1991. Print.

---. "I Pleady Guilty--But Where Is the Judgment?." Nepantla 3.3 (2002): 579-583. Web. 31 Jan. 2010.

---. In Defense of Lost Causes. London: Verso, 2008. Print.

---. "Lenin Shot at Finland Station." London Review of Books 27.16 (2005): 23. Web. 19 Dec. 2009.

---. On Belief. London: Routledge, 2001. Print. 
---. "Postface: Better Dead than Red--Again!." Sleeping Giant Has Awoken: The New Politics of Religion in the United States. Ed. Jeffrey W. Robbins \& Neal Magee. Continuum, 2008. Print.

---. Tarrying with the Negative: Kant, Hegel, and the Critique of Ideology. Durham: Duke UP, 1993. Print.

---. "The Big Other Doesn't Exist." Journal of European Psychoanalysis 5 (1997): n. pag. Web. 9 Aug. 2009.

---. The Fragile Absolute, or, Why Is the Christian Legacy Worth Fighting For? London: Verso, 2000. Print.

---. The Indivisible Remainder: An Essay On Schelling And Related Matters. London: Verso, 1996. Print.

---. The Parallax View. Cambridge, Mass.: MIT Press, 2006. Print.

---. The Puppet and the Dwarf: The Perverse Core of Christianity. Cambridge, Mass.: MIT Press, 2003. Print.

---. "The Rhetorics of Power." Diacritics 31.1 (2001): 91-104. Web. 1 Feb. 2010.

---. "The Spectre of Ideology." Mapping Ideology. Verso, 1995. Print.

---. The Sublime Object of Ideology. London: Verso, 1989. Print.

---. The Ticklish Subject: The Absent Centre of Political Ontology. London: Verso, 1999. Print.

Žižek, Slavoj, and Christopher Hanlon. "Psychoanalysis and the Post-Political: An Interview with Slavoj Žižek." New Literary History 32.1 (2001): 1-21. Web. 15 Feb. 2010.

Žižek, Slavoj, and John Milbank. The Monstrosity of Christ: Paradox or Dialectic? Cambridge, Mass.: MIT Press. Print. 